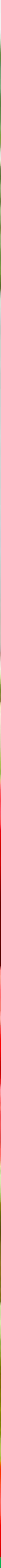

\title{
De Nederlandse landbouwexport in 2018 in breder perspectief
}





\title{
De Nederlandse landbouwexport 2018 in breder perspectief
}

Mark Dolman ${ }^{1}$, Gerben Jukema ${ }^{1}$ en Pascal Ramaekers² (EDS.)

\author{
1 Wageningen Economic Research
}

2 Centraal Bureau voor de Statistiek

Dit onderzoek is uitgevoerd door Wageningen Economic Research en het Centraal Bureau voor de Statistiek in opdracht van en gefinancierd door het ministerie van Landbouw, Natuur en Voedselkwaliteit.

Wageningen Economic Research

Wageningen, januari 2019

RAPPORT

2019-001

ISBN 978-94-6343-405-8 
Dolman, M.A., G.D. Jukema, P. Ramaekers (EDS.), 2019. De Nederlandse landbouwexport in 2018 in breder perspectief. Wageningen, Wageningen Economic Research, Rapport 2019-001. 136 blz.; 85 fig.; 33 tab.; 46 ref.

In dit rapport wordt beschreven hoe de handel in Nederlandse landbouwsectoren zich in 2018 heeft ontwikkeld. Wageningen Economic Research en CBS maken in deze gezamenlijke uitgave in opdracht van het Ministerie van LNV de eerste landbouwhandelscijfers bekend en voorzien deze van duiding. Daarnaast is beschreven hoeveel Nederland verdient aan de landbouwhandel, zijn patenten in de agro-industrie in kaart gebracht en is de stand van de technologische innovaties bij het agrarische bedrijfsleven geïnventariseerd. Verder wordt onder andere het aantal agrarische dochterondernemingen in het buitenland beschreven en is er informatie te vinden over afgestudeerde internationale studenten. Tot slot is er een beschouwing opgenomen over handel en circulariteit.

This report describes the trade developments in the agricultural sector in the Netherlands in 2018. In this joint publication by Wageningen Economic Research and Statistics Netherlands (CBS), which was commissioned by the Ministry of Agriculture, Nature and Food Quality (LNV), the initial trade results are announced and interpreted. Additionally, an overview of patents in the agricultural processing industry is given as well as an inventory of the current situation of technological innovations in the agricultural industry. The report also describes the number of agricultural subsidiaries abroad and contains information regarding foreign students who have graduated. Finally, a reflection on trade and circularity has been included.

Trefwoorden: landbouwexport, landbouwgerelateerde goederen, agribusiness, Duitsland, circulariteit, dienstenexport, kennisexport

Dit rapport is gratis te downloaden op https://doi.org/10.18174/468099 of op www.wur. nl/economicresearch (onder Wageningen Economic Research publicaties).

(C) 2019 Wageningen Economic Research

Postbus 29703, 2502 LS Den Haag, T 07033583 30, E communications.ssg@wur.nl, www.wur.nl/economic-research. Wageningen Economic Research is onderdeel van Wageningen University \& Research.

\section{(cc) BY-NC}

Wageningen Economic Research hanteert voor haar rapporten een Creative Commons Naamsvermelding 3.0 Nederland licentie.

(C) Wageningen Economic Research, onderdeel van Stichting Wageningen Research, 2019 De gebruiker mag het werk kopiëren, verspreiden en doorgeven en afgeleide werken maken. Materiaal van derden waarvan in het werk gebruik is gemaakt en waarop intellectuele eigendomsrechten berusten, mogen niet zonder voorafgaande toestemming van derden gebruikt worden. De gebruiker dient bij het werk de door de maker of de licentiegever aangegeven naam te vermelden, maar niet zodanig dat de indruk gewekt wordt dat zij daarmee instemmen met het werk van de gebruiker of het gebruik van het werk. De gebruiker mag het werk niet voor commerciële doeleinden gebruiken.

Wageningen Economic Research aanvaardt geen aansprakelijkheid voor eventuele schade voortvloeiend uit het gebruik van de resultaten van dit onderzoek of de toepassing van de adviezen.

Wageningen Economic Research is ISO 9001:2008 gecertificeerd.

Wageningen Economic Research Rapport 2019-001 | Projectcode 2282200455

Foto omslag: Shutterstock 


\section{Erratum bij Rapport 2019-001}

20 november 2019

In rapport 2019-001 De Nederlandse landbouwexport 2018 in breder perspectief staat helaas een passage over de import van soja ten behoeve van de Nederlandse varkenshouderij die niet goed de feitelijke situatie weerspiegelt. We hebben daarom de volgende aanpassing doorgevoerd in het rapport, op basis van de berekeningen van het sojaverbruik in de Nederlandse diervoederindustrie 2011-2013 (https://edepot.wur.nl/316027). De zin op pagina 111 "Varkens worden immers in belangrijke mate gevoerd met geïmporteerde soja en dat is dan niet meer voorhanden." is vervangen door de zin: "Voor varkens is (geïmporteerde) soja een belangrijke bron van hoogwaardig eiwit in veevoer, dat daarnaast voornamelijk bestaat uit producten van Nederlandse en Europese herkomst en waardevolle reststromen uit de levensmiddelenindustrie." 


\section{Inhoud}

$\begin{array}{ll}\text { Woord vooraf } & 7\end{array}$

$\begin{array}{ll}\text { Samenvatting } & 8\end{array}$

S.1 De Nederlandse handel in landbouwgoederen $\quad 8$

S.2 Nederlandse export van landbouwgoederen in breder perspectief 9

S.3 Kennis-, innovatie- en duurzaamheidsaspecten van internationalisering 10

$\begin{array}{ll}\text { S.4 Handel en circulariteit } & 11\end{array}$

Summary $\quad 12$

S.1 Dutch trade in agricultural goods $\quad 12$

S.2 Dutch export of agricultural goods in a wider perspective 13

S.3 Knowledge, innovation, and sustainability aspects of internationalisation $\quad 14$

$\begin{array}{ll}\text { S.4 Trade and circularity } & 15\end{array}$

\section{De Nederlandse handel in landbouwgoederen}

$\begin{array}{lll}2.1 & \text { Groei landbouwexport komt bijna tot stilstand } & 18\end{array}$

$\begin{array}{lll}2.2 & \text { Ruim een derde landbouwexport naar buurlanden } & 20\end{array}$

2.3 Divers beeld bij de landbouwgoederenhoofdstukken $\quad 23$

2.4 Handel in landbouwgoederen met Duitsland gedaald 39

3.1 Waarde appelexport ongeveer gelijk aan import

3.2 Positieve handelsbalans voor export van bevroren aardappelproducten uit Nederland

3.3 Export tomaten flink lager

3.4 Export snijbloemen ondanks warme zomer gegroeid

3.5 Exportgroei boomkwekerijproducten zet in 2018 door 59

3.6 Exportwaarde kaas 2\% gedaald in $2018 \quad 61$

3.7 Duitsland belangrijke handelspartner voor import en export van varkensvlees 64

$\begin{array}{lll}3.8 & \text { Duitsland blijft belangrijkste afzetmarkt voor Nederlandse eieren } & 67\end{array}$

3.9 Nederland bij uitstek bloemenbollenhandelsland 69

3.10 Handelsbalansoverschot van landbouwgerelateerde goederen toegenomen $\quad 72$

$\begin{array}{lll}4.1 & \text { Nederland behoudt exportpositie in wereld } & 75\end{array}$

$\begin{array}{lll}4.2 & \text { Prijsdaling dempt waardeontwikkelingen } & 77\end{array}$

4.3 Nederlandse landbouwgerelateerde machines in de lift 78

4.4 Nederland verdient meest aan traditionele landbouwexport $\quad 82$

5.1 Agribusiness importeert meer diensten dan het exporteert 85

5.2 Innovatie en R\&D volop in de aandacht $\quad 88$

5.3 Patenten stabiele innovatiemotor in voedingsmiddelen- en drankenindustrie 92

5.4225 dochterondernemingen van voeding en drank buiten EU 98

5.5 Relatief veel internationale landbouwalumni verlaten Nederland 101

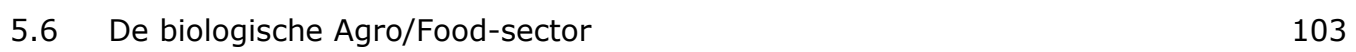

5.7 Mate van gebruik duurzame agrogrondstoffen in Nederland wisselend 105 
$\begin{array}{lll}6.1 & \text { Inleiding } & 107\end{array}$

6.2 Mondiaal transport 107

6.3 Europees evenwicht 108

6.4 Nationaal evenwicht 111

6.5 Slotbeschouwingen 112

$\begin{array}{ll}\text { Literatuur en websites } & 114\end{array}$

$\begin{array}{lll}\text { Bijlage } 1 & \text { Lijst van auteurs } & 117\end{array}$

Bijlage 2 Dataverantwoording 118

$\begin{array}{llr}\text { Bijlage } 3 & \text { Begrippenlijst } & 127\end{array}$

Bijlage 4 Uitgebreide tabellen handel in landbouwgoederen 131 



\section{Woord vooraf}

De minister van Landbouw, Natuur en Voedselkwaliteit (LNV) blikt elk jaar terug op de Nederlandse landbouwexportprestaties in het voorgaande jaar. Traditioneel gebeurt dit in januari, tijdens de Grüne Woche, de grootste landbouwbeurs van Europa. In de aanloop naar de Grüne Woche 2019 maken het CBS en Wageningen Economic Research in opdracht van het ministerie van LNV een raming van de exportprestaties in 2018. Met trots wordt hier deze nieuwe editie gepresenteerd.

Nederland is al vele jaren een belangrijke wereldspeler in de agribusiness. Nederland is de op één na grootste landbouwexporteur; in export moet het de Verenigde Staten voor laten gaan, in netto-export (export minus import) Brazilië en Argentinië. De Nederlandse landbouwexport omvat bovengemiddeld veel goederen van Nederlandse makelij (bijna 73\%) in vergelijking met het gehele goederenpakket van Nederland (ruim 55\%).

Naast inzicht in de traditionele export- en importcijfers heeft het Ministerie van LNV dit jaar verzocht om de jaarlijkse publicatie over exportcijfers verder uit te breiden met informatie die aansluit op en inzicht geeft in de transitie naar kringlooplandbouw en versterking van de verbinding tussen landbouw en natuur en dus aansluit bij de visie van de minister van LNV. Onder de kop 'Innovatieve wereldspeler' wordt in de visie de link beschreven tussen agro-innovatie en de Nederlandse positie op de wereldmarkt. Hierop voortbordurend, zijn in deze publicatie een aantal beschrijvende statistieken en duidingen over de export van landbouwkennis, duurzame landbouw en een casestudie over de invoer van veevoergrondstoffen opgenomen.

In 2018 exporteerde Nederland volgens ramingen voor 90,3 miljard euro aan landbouwgoederen. Dit is een groei ( $+0,2 \%$ ten opzichte van 2017), maar betekent wel dat de grote landbouwbouwexportgroei van de laatste jaren nagenoeg tot stilstand komt. Prijsdalingen zijn een belangrijke verklaring voor de lagere groei van de landbouwexportwaarde dan in vorige jaren. Naast landbouwgoederen exporteerde Nederland voor 9,2 miljard euro aan landbouwgerelateerde goederen, zoals melkrobots of machines voor de voedingsmiddelenindustrie. Dat is een flinke groei $(+3,2 \%)$ ten opzichte van 2017. Deze groei wordt volledig veroorzaakt door een toename van de uitvoer van goederen van Nederlandse makelij. Gegevens over de export van landbouwgerelateerde goederen zijn belangrijk voor het totale inzicht in de transitie van de Nederlandse agribusiness naar de export van kennis, (duurzame) technologie en innovaties.

Nederland verdient in 2018 net als in 2017 circa 45 miljard euro aan de export van landbouwgoederen inclusief landbouwgerelateerde goederen. In 2018 gaat het om circa 41,5 miljard euro uit de export van goederen van Nederlandse makelij en circa 3,5 miljard euro uit wederuitvoer.

In deze publicatie vindt u meer feiten over de Nederlandse handel in landbouwgoederen en de kennis-, innovatie- en duurzaamheidaspecten daarvan. Bij dezen wil ik iedereen die een bijdrage heeft geleverd van Wageningen Economic Research en het CBS hartelijk danken voor hun inspanningen.

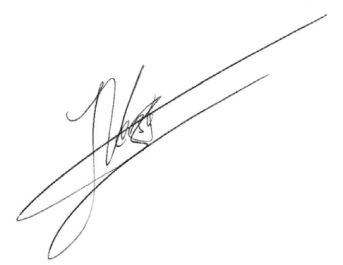

Prof.dr.ir. J.G.A.J. (Jack) van der Vorst Algemeen Directeur Social Sciences Group (SSG) Wageningen University \& Research 


\section{Samenvatting}

\section{S.1 De Nederlandse handel in landbouwgoederen}

- De export van landbouwgoederen wordt voor 2018 geraamd op 90,3 miljard euro (figuur S.1). Dat is $0,2 \%$ meer dan het definitieve cijfer voor $2017(90,1 \text { miljard euro })^{1}$ en steekt schril af tegen de voorgaande twee jaren (in 2016 ruim 4\% groei en in 2017 ruim 6\% groei). Ook de import van landbouwgoederen groeit $(0,5 \%)$ en wordt voor 2018 geraamd op 61,4 miljard euro. Door de iets sterker groeiende landbouwimport in vergelijking met de landbouwexport komt het landbouwhandelsoverschot ook iets lager $(-0,4 \%)$ uit dan in 2017: van 28,9 naar 28,8 miljard euro. Het landbouwhandelsoverschot laat een opvallende ontwikkeling zien ten opzichte van het totale geraamde goederenhandelsoverschot van Nederland. Na een vrijwel continue afname van het landbouwaandeel van $68 \%$ in 2008 tot $49 \%$ in 2017, schiet het aandeel in 2018 weer omhoog naar $58 \%$. Zie paragraaf 2.1 .
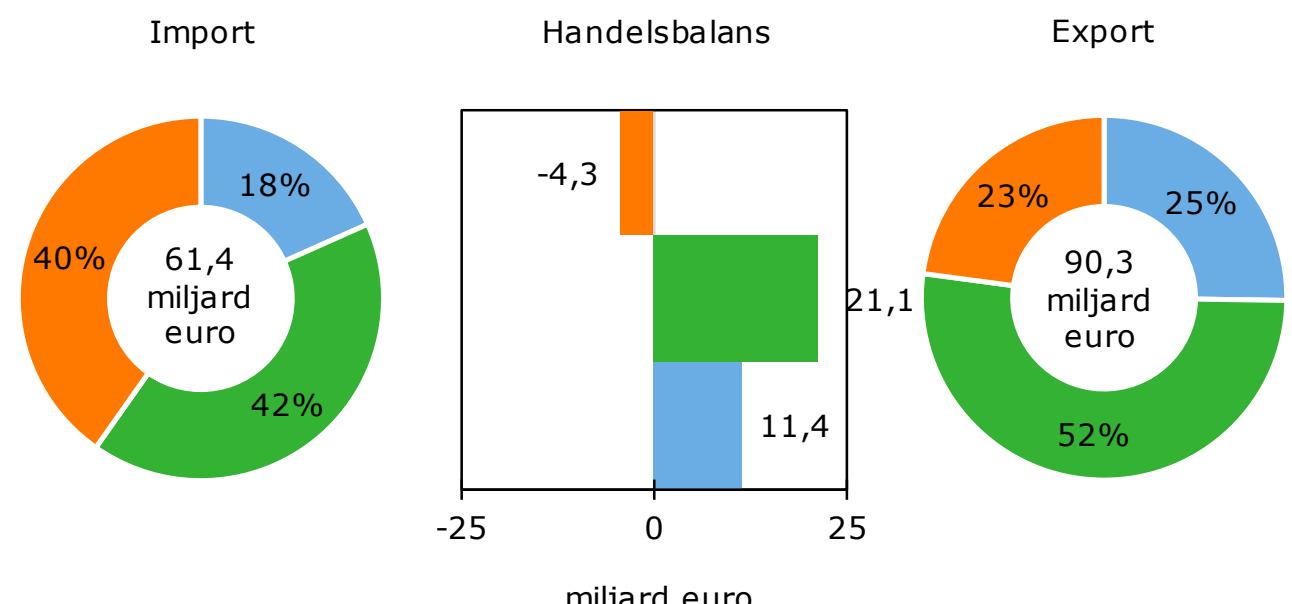

Duitsland $\quad$ Rest van EU-28 Rest van de wereld

Figuur S.1 Import en export van landbouwgoederen in 2018 naar regio.

Bron: CBS tot en met oktober 2018, raming november - december 2018 door WUR en CBS.

- De meeste landbouwexport gaat in 2018 , net als alle voorgaande jaren, naar onze buurlanden: voor 22,8 miljard euro naar Duitsland en voor 10,2 miljard euro naar België. Daarna volgen als belangrijkste afnemers het Verenigd Koninkrijk, Frankrijk, Italië, Spanje, de Verenigde Staten, China, Polen en Zweden. De grootste absolute afnames in de Nederlandse landbouwexport betreffen de topbestemmingen Duitsland (-310 miljoen euro), Frankrijk (-97 miljoen euro) en het Verenigd Koninkrijk (-72 miljoen euro). Bij al deze bestemmingen gaat het om procentueel geringe afnames van circa $1 \%$ ten opzichte van 2017. De belangrijkste absolute stijgers zijn Japan ( +110 miljoen euro), Marokko (+93 miljoen euro), Polen (+86 miljoen euro), Rusland (+77 miljoen euro) en China (+66 miljoen euro). In het geval van Marokko $(+36 \%)$ en Japan $(+17 \%)$ gaat het om aanzienlijke groeipercentages. Zie paragraaf 2.2 en voor Duitsland paragraaf 2.4 .

- Sierteeltproducten (9,2 miljard euro), zuivel en eieren (8,5 miljard euro), vlees (8,1 miljard euro), groente $(6,6$ miljard euro) en fruit $(6,0$ miljard euro) zijn bij de export de belangrijkste

\footnotetext{
${ }^{1}$ Als gevolg van methodologische wijzigingen zijn de definitieve cijfers in de goederenhandelsstatistiek voor 2017 en eerdere jaren naar beneden bijgesteld en is de geraamde landbouwexport voor 2018 nu de hoogste waarde ooit, hoewel deze lager ligt dan de oorspronkelijke raming voor 2017 (voor de methodologische wijzingen). Zie verder de dataverantwoording in de bijlage.
} 
goederengroepen. De grootste absolute groei in de exportwaarde vond plaats bij bereidingen van graan, zetmeel, meel en melk ( $+0,5$ miljard euro), fruit $(+0,5$ miljard euro) en sierteeltproducten $(+0,3$ miljard euro). De grootste daling in exportwaarde vond plaats bij tabak en tabaksproducten $(-0,5$ miljard euro), natuurlijke vetten en oliën ( $-0,5$ miljard euro) en cacao en cacaobereidingen $(-0,4$ miljard euro). Bij de import zijn fruit (6,2 miljard euro), natuurlijke vetten en oliën (4,5 miljard euro), zuivel en eieren (4,2 miljard euro) en cacao en cacaobereidingen (3,9 miljard euro) het belangrijkst. De grootste absolute groei in importwaarde vond plaats bij fruit $(+0,4$ miljard euro), bereidingen van graan, zetmeel, meel en melk $(+0,3$ miljard euro) en zuivel en eieren $(+0,3$ miljard euro). De grootste absolute daling in importwaarde vond plaats bij natuurlijke vetten en oliën $(-0,8$ miljard euro), tabak en tabaksproducten (-0,2 miljard euro) en oliehoudende zaden en vruchten (-0,2 miljard euro). Zie paragraaf 2.3 voor de ontwikkelingen per GN-02goederenhoofdstuk, of voor uitgelichte landbouwgoederen hoofdstuk 3.

- De exportwaarde van landbouwgerelateerde goederen in 2018 steeg naar een record van 9,2 miljard euro $(+3,2 \%)$. Duitsland is de belangrijkste exportbestemming voor landbouwgerelateerde goederen (1,4 miljard euro), gevolgd door België (0,9 miljard euro), Frankrijk (0,7 miljard euro) en het Verenigd Koninkrijk (0,6 miljard euro). De export van machines voor de voedingsmiddelenindustrie nam fors toe $(+316$ miljoen; $+19 \%)$. De grootste daler bij de export was de export van meststoffen (-120 miljoen euro; $-7 \%)$. Zie paragraaf 3.10.

\section{S.2 Nederlandse export van landbouwgoederen in breder perspectief}

- Ook in 2017 is Nederland de op één na grootste landbouwexporteur van de wereld. De Verenigde Staten van Amerika (VS) blijven de nummer 1. Duitsland, Brazilië en China vullen de top vijf van belangrijkste exportlanden op landbouwgebied in 2017 aan. Een opvallend verschil tussen de landen is dat in deze top vijf Brazilië en Nederland netto-exporteurs zijn, terwijl de Verenigde Staten, Duitsland en vooral China meer importeren dan exporteren. Brazilië is zelfs de grootste nettoexporteur op landbouwgebied in de wereld, gevolgd door Argentinië en als derde Nederland. Zie paragraaf 4.1.

- Prijsdalingen zijn een belangrijke verklaring voor de lagere groei van de landbouwexportwaarde dan in vorige jaren. Tegenover een prijsdaling van $0,7 \%$ in 2018 staat een grotere volumegroei van $0,9 \%$, waardoor de waardegroei uitkomt op 0,2\%. Bij de import van landbouwgoederen is de richting van de volume- en prijsontwikkelingen dezelfde, maar zijn de verschillen forser. Een volumegroei van $2,4 \%$ overstijgt de prijsdaling van $1,9 \%$, waardoor de waardegroei uitkomt op $0,5 \%$. Zie paragraaf 4.2 .

- De 90,3 miljard euro aan export van landbouwgoederen betreft 65,4 miljard euro aan export van goederen van Nederlandse makelij en 24,9 miljard euro wederuitvoer van goederen van buitenlandse makelij. Tot de goederen van Nederlandse makelij behoren ook bewerkte producten (bijvoorbeeld chocola) op basis van geïmporteerde grondstoffen (zoals cacaobonen). Inclusief landbouwgerelateerde goederen gaat het om 72,3 miljard euro aan export van goederen van Nederlandse makelij en 27,2 miljard aan wederuitvoer. De meest opvallende ontwikkeling betreft de exportgroei bij de landbouwgerelateerde goederen van Nederlandse makelij met een toename van bijna $5 \%$ ten opzichte van 2017. Dan gaat het met name om een exporttoename van Nederlandse landbouw- en voedingsmachines. De Nederlandse landbouwexport omvat bovengemiddeld veel goederen van Nederlandse makelij (bijna 73\%) in vergelijking met het gehele goederenpakket van Nederland (ruim 55\%). Zonder wederuitvoer blijft sierteelt bovenaan staan als meest exporterende goederengroep op basis van de eerste twee digits van de GN-indeling. Vlees springt van drie naar twee, ten koste van zuivel en eieren. Groente blijft op plek vier. Zie paragraaf 4.3.

- Nederland verdient in 2018 net als in 2017 circa 45 miljard euro aan de export van landbouwgoederen inclusief landbouwgerelateerde goederen. In 2018 gaat het om circa 41,5 miljard euro uit de export van goederen van Nederlandse makelij en circa 3,5 miljard euro uit wederuitvoer. Zie paragraaf 4.4 . 


\section{S.3 Kennis-, innovatie- en duurzaamheidsaspecten van internationalisering}

- Naast goederenexport is er ook sprake van export van landbouwgerelateerde diensten. De Nederlandse agribusiness importeert meer diensten dan het exporteert. In 2016 ging het om een import ter waarde van circa 4,7 miljard euro tegenover een export ter waarde van 2,3 miljard euro. De sterke link met de goederenexport blijkt uit de op wegvervoer na meest verhandelde dienstensoort met het buitenland: diensten in verband met de be- en verwerking van goederen. De top twintig betreft verder vervoersdiensten, kennisintensieve diensten (zoals R\&D-diensten en wetenschappelijke diensten) en zakelijke diensten (zoals zakelijk advies en public relations). Zie paragraaf 5.1 .

- In de periode 2014-2016 is het aandeel technologisch innovatieve bedrijven binnen het totale aantal bedrijven met meer dan 10 werkzame personen ten opzichte van de periode 2012-2014 met 1 procentpunt gestegen naar $38 \%$. In de agribusiness is het aandeel innovatoren juist met 5 procentpunt gedaald, naar $36 \%$ van het totale aantal bedrijven. Wel is het aandeel bedrijven met gerealiseerde technologische innovaties in de agribusiness gestegen (sterke daling van onvoltooide of afgebroken innovaties). In 2016 zijn de R\&D-uitgaven van de agribusiness gestegen, zowel in absolute zin als in het aandeel van de uitgaven voor technologische innovatie. Productinnovatie is de laatste jaren belangrijker geworden voor de agribusiness. Zie paragraaf 5.2.

- Het aantal aangevraagde patenten in de voedingsmiddelen- en drankenindustrie (en daaraan gerelateerde activiteiten) heeft zich na de crisis hersteld, maar zit nog niet op het niveau van het begin van deze eeuw. De samenwerking van Nederlandse uitvinders met buitenlandse speelt een grotere rol dan die van louter Nederlandse uitvinders bij het aantal aangevraagde patenten in de voedings- en drankenindustrie. Dat is een ander beeld dan bij de totale industrie, waar Nederlandse uitvinders juist een grotere rol spelen. Wel is het aantal Nederlandse patentaanvragen in de voedings- en drankenindustrie stabiel, terwijl de (deels) buitenlandse aanvragen een dalende trend vertonen. Zie paragraaf 5.3.

- In 2016 hadden Nederlandse bedrijven 225 dochterondernemingen in de voedingsmiddelen- en drankenindustrie buiten de Europese Unie. Dat is een kleine toename na een aantal jaren waarin het aantal bedrijven flink afnam. In 2012 waren er nog 335. In 2016 waren er in Nederland 6.400 bedrijven actief in de voedings- en drankenindustrie, waarvan 183 een buitenlandse moedermaatschappij hadden. In vergelijking met 2007 is zowel het aantal Nederlandse als het aantal buitenlandse bedrijven in deze branche in Nederland met een kwart toegenomen. Zie paragraaf 5.4 .

- Ruim vier jaar na het afstuderen is nog $24 \%$ van het aantal geregistreerde internationale studenten aan de Universiteit Wageningen woonachtig in Nederland. Het aantal werkenden ligt na ruim vier jaar op $15 \%$ van het oorspronkelijke aantal ingeschreven afgestudeerden. Het aantal alumni met bedrijfsoprichtingen in Nederland bedraagt na zeven jaar $2 \%$ van het oorspronkelijke aantal. Dat blijkt uit een onderzoek naar de afgestudeerde studenten van afstudeerjaar 2009/2010. De weergegeven percentages liggen lager dan de percentages voor alle universiteiten in Nederland samen. Wageningen is na Maastricht en Twente de meest internationaal georiënteerde universiteit van Nederland en trekt relatief veel Chinese studenten. Zie paragraaf 5.5.

- De biologische agro/food-sector is beperkt in omvang, maar groeit nog steeds. Eind 2017 waren er in Nederland 1.696 gecertificeerde landbouwbedrijven voor biologische productie. Ten opzichte van 2016 is dat een toename van $9 \%$. Daarmee is 2,9\% van de bedrijven uit de landbouwtelling biologisch. Zie paragraaf 5.6.

- In Nederland hebben marktpartijen zich verbonden aan concrete mijlpalen op weg naar een toenemend gebruik van duurzaam geproduceerde agrogrondstoffen. Dit streven is vastgelegd met convenanten en initiatieven en de resultaten worden gemonitord. Het CBS toetst de gebruikte meetmethoden. In het algemeen is er een trend van toenemende duurzame import, maar er zijn wel verschillen tussen de verschillende goederen. Zie paragraaf 5.7. 


\section{S.4 Handel en circulariteit}

- In de visie van het ministerie van LNV wordt kringlooplandbouw bepleit, om ervoor te zorgen dat de sector minder broeikasgassen uitstoot, de bodemkwaliteit verbetert en eindige grondstoffen, zoals fosfor, efficiënter worden gebruikt. Om de consequenties van kringlooplandbouw voor de Nederlandse handelspositie inzichtelijk te maken, zijn eerste-orde effecten van drie scenario's uitgewerkt: sluiting van de kringloop op mondiale schaal, op Europese schaal en op nationale schaal. Zie paragraaf 6.1.

- In het mondiale scenario sluit Nederland de voer-mestkringloop door mineralen (uit bewerkte mest) terug te transporteren naar de landen waar de voederproductie plaatsvindt. De sector kan de huidige prestaties op het gebied van productie, toegevoegde waarde en export blijven realiseren, omdat de Nederlandse veestapel onveranderd kan blijven. Met de uitvoer van mest naar gebieden met mesttekorten zal de mineralenbalans beter in evenwicht komen en zullen de verliezen veel geringer zijn, maar de uitstoot van broeikasgassen $\left(\mathrm{CO}_{2}\right.$, methaan en lachgas) en ammoniak zal niet verminderen. De rol van de overheid ligt vooral op het vlak van regelgeving (bijvoorbeeld via bestemmingsplannen), door mestverwerkingslocaties mogelijk te maken. Zie paragraaf 6.2.

- Bij het sluiten van de kringloop op Europese schaal wordt de invoer van veevoergrondstoffen vervangen door eigen teelt of wordt er meer geïmporteerd uit Oekraïne. Op korte termijn zal dat laatste het meeste soelaas kunnen bieden, maar een forse daling van het aanbod van eiwithoudende gewassen ten behoeve van de veevoerindustrie is onafwendbaar. De veestapel zal dalen met een kwart, en daardoor ook de uitvoer van zuivel en vlees (in dezelfde orde van grootte). Een kleinere veestapel leidt tot minder stikstofverliezen, doordat er minder dieren zijn, maar de aanwending van stikstof en fosfaat op de bedrijven zal hetzelfde blijven, doordat de gebruiksnormen niet veranderen. De productie van mest en het fosfaatoverschot dalen wel en dat vertaalt zich in minder export van mest en fosfaat naar het buitenland. Zie paragraaf 6.3.

- Als Nederland de voer-mestkringloop op eigen grond sluit door de omvang van de veehouderij te reduceren tot deze in balans is met de feitelijke omvang van de voederproductie, zal het aantal dieren in de rund- en pluimveesector kunnen halveren en de varkensstapel waarschijnlijk nog sterker afnemen. Voor een nauwkeurigere duiding van de effecten van dat scenario zijn aanvullende berekeningen en veronderstellingen nodig (bijvoorbeeld over teeltverschuivingen). Duidelijk is dat dit scenario forse economische gevolgen heeft voor de sector, terwijl er geen problemen meer zijn rond mest en mineralenconcentraties. Er zijn geen instrumenten voorhanden om de voorziening van de veehouderij met uitsluitend nationaal geteelde veevoergrondstoffen te realiseren. Zie paragraaf 6.4. Sturen op de mest- en mineralenproductie, via bijvoorbeeld aanwendingsnormen of dierrechten, is dan effectiever. Zie paragraaf 6.5. 


\section{Summary}

\section{S.1 Dutch trade in agricultural goods}

- The export of agricultural goods is estimated at 90.3 billion euros in 2018 (figure S.1). This is $0.2 \%$ more than the definitive figure for 2017 ( 90.1 billion euros) ${ }^{2}$ and is in stark contrast with the previous two years (over 4\% growth in 2016 and over 6\% growth in 2017). The import of agricultural goods is also growing $(0.5 \%)$ and is estimated at 61.4 billion euros for 2018 . Due to the slightly stronger growth in agricultural imports compared to agricultural exports, the agricultural trade surplus is slightly lower (-0.4\%) than in 2017: from 28.9 to 28.8 billion euros. The agricultural trade surplus shows a striking development when compared to the total estimated goods trade surplus in the Netherlands. After a fairly continuous decrease in the agricultural share from $68 \%$ in 2008 to $49 \%$ in 2017 , the share shot back up to $58 \%$ in 2018 . See section 2.1 .

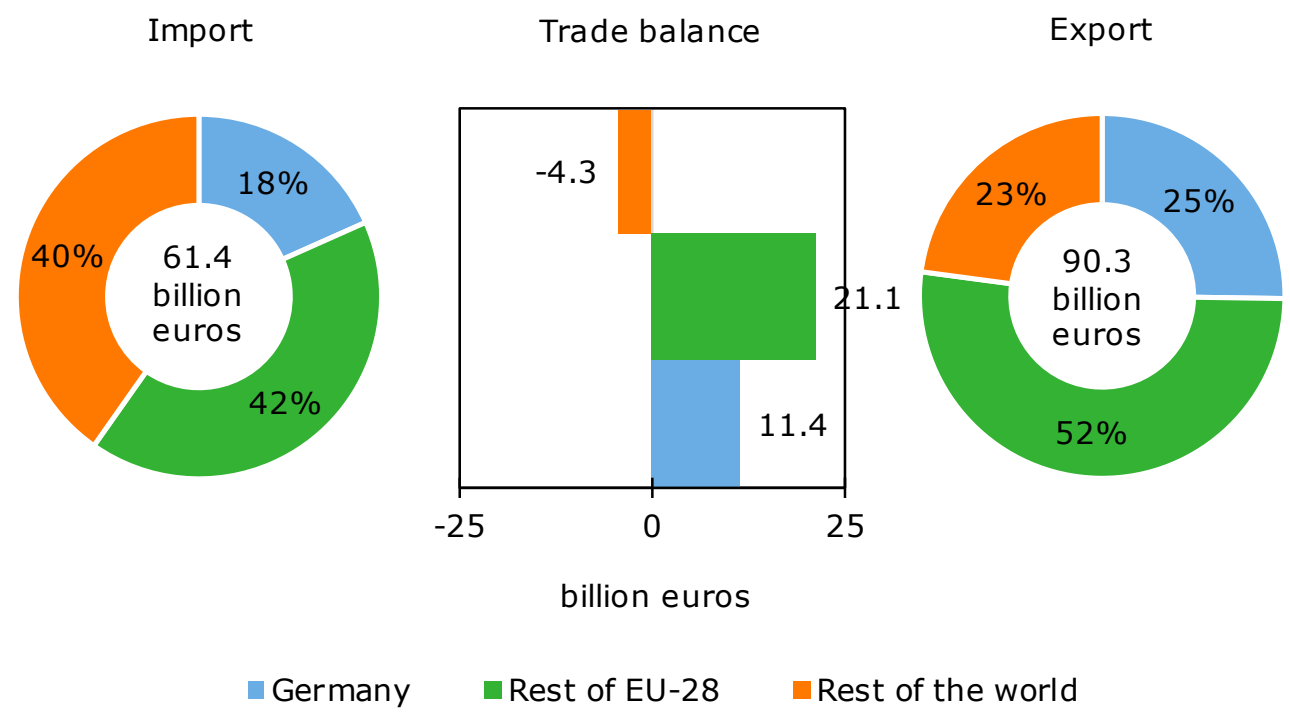

Figure S.1 Import and export of agricultural goods by region in 2018.

Source: CBS - until October 2018, estimate November - December by WUR and CBS.

- As with all previous years, most agricultural exports go to our neighbouring countries: a value of 22.8 billion euros to Germany and 10.2 billion euros to Belgium. After that, the most important customers are the United Kingdom, France, Italy, Spain, the United States, China, Poland, and Sweden. The largest absolute decrease in sales within Dutch agricultural exports are in relation to nearly all the top destinations: Germany (-310 million euros), France (-97 million euros), and the United Kingdom ( -72 million euros). All these destinations show a slight percentage decrease of about $1 \%$ when compared to 2017 . The most important absolute increases are for Japan $(+110$ million euros), Morocco (+93 million euros), Poland (+86 million euros), Russia (+77 million euros), and China (+66 million euros). In the case of Morocco $(+36 \%)$ and Japan $(+17 \%)$, the percentage of increase is substantial. See section 2.2 and section 2.4 for Germany.

\footnotetext{
2 As a result of the methodological changes, the definitive figures of the goods trade statistics for 2017 and previous years were adjusted downwards, and the estimated agricultural export for 2018 is currently the highest value ever, although it is lower than the original estimate for 2017 (before the methodological changes). For more information, see the data description in the appendix.
} 
- Floriculture products ( 9.2 billion euros), dairy products and eggs ( 8.5 billion euros), meat ( 8.1 billion euros), vegetables ( 6.6 billion euros), and fruit ( 6.0 billion euros) are the most important goods categories for export. The largest absolute growth in export value was for preparations of grain, starch, flour, and milk ( +0.5 billion euros), fruit ( +0.5 billion euros), and floriculture products ( +0.3 billion euros). The largest decrease in export value was found in tobacco and tobacco products ( -0.5 billion euros), natural oils and fats ( -0.5 billion euros), and cocoa and cocoa products (- 0.4 billion euros). The most important categories for import are fruit ( 6.2 billion euros), natural oils and fats ( 4.5 billion euros), dairy products and eggs ( 4.2 billion euros), and cocoa and cocoa products ( 3.9 billion euros). The largest absolute growth in import value was for fruit ( +0.4 billion euros), preparations of grain, starch, flour, and milk ( +0.3 billion euros), and dairy products and eggs ( +0.3 billion euros). The largest absolute decrease in import value was for natural oils and fats ( -0.8 billion euros), tobacco and tobacco products ( -0.2 billion euros), and oleaginous seeds and fruits ( -0.2 billion euros). See section 2.3 for the developments for each GN-02 goods category, or chapter 3 for selected agricultural goods.

- The export value of agriculture-related goods increased to a record 9.2 billion euros $(+3.2 \%)$ in 2018. Germany is the most important export destination for agriculture-related goods ( 1.4 billion euros), followed by Belgium ( 0.9 billion euros), France ( 0.7 billion euros), and the United Kingdom ( 0.6 billion euros). The export of machines for the feed and food industry increased strongly $(+316$ million euros; $+19 \%)$. The largest decrease for export was in fertiliser $(-120$ million euros; $7 \%)$. See section 3.10 .

\section{S.2 Dutch export of agricultural goods in a wider perspective}

- In 2017, the Netherlands is once again the second largest exporter of agricultural goods in the world. The United States remain number 1. Germany, Brazil, and China round out the top of the most important export countries in the agricultural field for 2017. A striking difference between the countries is that, in this top 5, Brazil and the Netherlands are net exporters, while the United States, Germany, and especially China import more than they export. Brazil is actually the largest net agricultural exporter in the world, followed by Argentina, with the Netherlands in third place. See section 4.1 .

- Price reductions are an important explanation for the slower growth of the agricultural export value compared to previous years. A price reduction of $0.7 \%$ in 2018 is countered by a larger volume growth of $0.9 \%$, which means the value growth is $0.2 \%$. The import of agricultural goods shows the same direction in the developments of volume and price, but the differences are larger. A volume growth of $2.4 \%$ exceeds the price reduction of $1.9 \%$, which means the value growth is $0.5 \%$. See section 4.2 .

- The 90.3 billion euros in agricultural goods export consists of 65.4 billion euros of goods of Dutch origin and 24.9 billion euros of re-export of foreign goods. Goods of Dutch origin also include prepared products (like chocolate) based on imported raw materials (like cocoa beans). Including the agriculture-related products, it entails 72.3 billion euros of export of goods of Dutch origin and 27.2 billion of re-export. The most striking development is in relation to growth in the export of agriculture-related goods of Dutch origin, with an increase of nearly $5 \%$ compared to 2017 . This mainly concerns an increase in the export of Dutch feed and food machinery. Dutch agricultural export consists of an above-average amount of goods of Dutch origin (nearly $73 \%$ ) when compared to the total goods package of the Netherlands (over 55\%). Excluding re-export, floriculture remains on top as the most-exported goods category based on the first two digits of the GN classification. Meat jumps from three to two, overtaking dairy products and eggs. Vegetables remain in fourth place. See section 4.3.

- As in 2017, the Netherlands earned about 45 billion euros from the export of agricultural goods, including agriculture-related goods in 2018. In 2018, this entails about 41.5 billion euros from the export of goods of Dutch origin and about 3.5 billion euros from re-export. See section 4.4. 


\section{S.3 Knowledge, innovation, and sustainability aspects of internationalisation}

- Besides the export of goods, there is also export of agriculture-related services. Dutch agribusiness imports more services than it exports. In 2016, this was 4.7 billion euros of imports in comparison to 2.3 billion euros of exports. The strong link with goods export is clear from the second-most internationally traded service after road transport: services related to the processing and handling of goods. The top twenty also includes transport services, knowledge intensive services (such as R\&D services and scientific services), and business services (such as business advice and public relations). See section 5.1 .

- In the 2014-2016 period, the number of technologically innovative companies within the total number of companies with more than 10 employees has grown by 1 percentage point to $38 \%$ when compared to the 2012-2014 period. The share of innovators in the agribusiness has in fact decreased by 5 percentage points, to $36 \%$ of the total number of businesses. However, the share of businesses with realised technological innovations in the agribusiness has grown (strong decrease in incomplete or aborted innovations). In 2016, the R\&D expenditure for agribusiness has increased, in absolute terms as well as in the share of expenditure for technological innovation. Product innovation has become more important for agribusiness over the past few years. See section 5.2.

- The number of patents filed within the food and beverage industry (and related activities) has recovered after the crisis, but is still not back at the same level as at the start of the century. The cooperation between Dutch and international inventors plays a larger role than those by Dutch inventors only in the number of patents filed in the food and beverage industry. This is a different picture than throughout the entire industry, in which Dutch inventors are more important. However, the number of Dutch patent applications in the food and beverage industry is stable, whereas the (partly) foreign applications show a downward trend. See section 5.3.

- In 2016, Dutch companies had 225 subsidiaries in the food and beverage industry outside the European Union. That is a slight increase after a few years during which the number of companies steeply declined. There were 335 in 2012. In 2016, 6400 companies were active in the Netherlands in the food and beverage industry, which includes 183 with a foreign parent company. Compared to 2007 , both the number of Dutch as well as the number of foreign companies in this industry in the Netherlands have increased by approximately $25 \%$. See section 5.4.

- Over four years after graduation, $24 \%$ of the registered international students at Wageningen University still live in the Netherlands. After four years, the number of employed people stands at $15 \%$ of the original number of registered students. The number of alumni with business start-ups in the Netherlands is at $2 \%$ of the original number after seven years. These figures are based on an investigation of international graduates from the 2009-2010 academic year. The reported percentages are lower than the percentages for all universities in the Netherlands combined. Wageningen is the third-most internationally oriented university in the Netherlands, after Maastricht and Twente, and attracts a relatively large number of Chinese students. See section 5.5.

- The organic agro-food sector is limited in size, but is still growing. At the end of 2017, there were 1696 certified agricultural businesses for organic production in the Netherlands. This is an increase of $9 \%$ compared to 2016 . This makes $2.9 \%$ of the companies in the agricultural census organic. See section 5.6.

- Market participants in the Netherlands have committed to concrete milestones on the way to an increased use of sustainably produced agro-resources.

The targets are established using agreements and initiatives and the results are monitored. The Statistics Netherlands (CBS) tests the measurement methods used. In general, there is a trend towards increasing sustainable imports, but there are differences between the various goods. See section 5.7 . 


\section{S.4 Trade and circularity}

- The vision of the Ministry of Agriculture, Nature and Food Quality (LNV) advocates circular agriculture to ensure that the sector reduces greenhouse gas emissions, improves the soil quality, and uses finite resources, such as phosphorus, more efficient. To gain insight into the consequences of circular agriculture for the Dutch trade position, first-order effects of three scenarios are detailed: closing the cycle on a global scale, on European scale, and on a national scale. See section 6.1.

- In the global scale scenario, the Netherlands closes the feed-manure cycle by re-transporting minerals (from processed manure) to the countries where the feed production takes place. The sector can continue the current achievements in the areas of production, added value, and exports, because the Dutch livestock population can remain unchanged. Exporting manure to areas with a manure shortage will increase the mineral balance and the losses will be much smaller, but the emission of greenhouse gasses ( $\mathrm{CO}_{2}$, methane, and nitrous oxide) and ammonia will not be reduced. The government's role will be mainly in the area of regulation (e.g. in zoning plans), by enabling the creation of manure-processing locations. See section 6.2.

- In closing the cycle on European scale, the import of feed resources will be replaced by internal cultivation or more will be imported from Ukraine. In the short term, the latter will offer most relief, but a substantial decrease in the supply of protein crops for the purpose of the feed industry will be inevitable. The livestock population will shrink by a quarter and in turn, the export of dairy and meat (by the same measure). A smaller livestock population will lead to reduced loss of nitrogen, because there are fewer animals, but the use of nitrogen and phosphates will remain the same at the businesses, as the usage standards do not change. The production of manure and the phosphate surplus will decrease, which will translate into a decrease in the export of manure and phosphates. See section 6.3.

- If the Netherlands closes the feed-manure cycle on national soil by reducing the size of livestock farming until it is in balance with the actual size of the feed production, the number of animals in the beef and poultry sector will need to be halved and the pig population would likely need to decrease even more. For a more accurate interpretation of the effects of that scenario, further calculations and assumptions will need to be made (for instance, regarding changes to cultivation). However, it is clear that this scenario has major economic implications for the sector, although there are no longer problems relating to manure and mineral concentrations. There are no instruments available to achieve the exclusive supply of livestock farming with nationally grown feed resources. See section 6.4. Adjusting manure and mineral production as a guide, for instance through usage standards or animal rights, is more effective in that case. See section 6.5. 


\section{$1 \quad$ Inleiding}

Hoe presteerde de Nederlandse landbouwsector internationaal in 2018? Traditiegetrouw presenteert de minister van Landbouw, Natuur en Voedselkwaliteit (LNV) tijdens de Grüne Woche in januari de raming van de Nederlandse export van landbouwgoederen in het voorgaande jaar, zowel het totaal als specifiek de export naar Duitsland. In dat kader hebben Wageningen Economic Research en het Centraal Bureau voor de Statistiek (CBS) de opdracht gekregen om een raming op te stellen ten aanzien van de omvang van de Nederlandse landbouwhandel (2018) en de positie van de Nederlandse landbouwhandel in de wereld (2017). Een groot deel van deze publicatie gaat daarom ook over de ontwikkelingen in de handel in landbouw- en landbouwgerelateerde goederen (zie kader).

Naast inzicht in de traditionele export- en importcijfers heeft het ministerie van LNV verzocht om deze publicatie verder uit te breiden met informatie die aansluit op en inzicht geeft in de transitie naar kringlooplandbouw en versterking van de verbinding tussen landbouw en natuur en dus aansluit bij de visie van de Minister van LNV. Onder de kop 'Innovatieve wereldspeler' wordt in deze visie de link beschreven tussen agro-innovatie en onze positie op de wereldmarkt. Hierop voortbordurend, is in deze publicatie een aantal beschrijvende statistieken en duidingen opgenomen over de export van landbouwkennis en duurzame landbouw, alsmede een casestudie over de invoer van veevoergrondstoffen. In de casestudie wordt gekeken naar de economische en ecologische gevolgen van het sluiten van kringlopen op mondiaal, Europees en nationaal niveau en welk beleid (governance) daarvoor nodig is.

\section{Definitie van landbouwgoederen en landbouwgerelateerde goederen}

Wat precies onder landbouwgoederen valt, is een definitiekwestie. Wageningen Economic Research heeft samen met het CBS en het ministerie van Landbouw, Natuur en Voedselkwaliteit (LNV) enkele jaren geleden bepaald welke goederen wel en niet onder de definitie van landbouwgoederen vallen. De landbouwgoederenhandel zoals gebruikt in deze publicatie omvat de eerste 24 goederenhoofdstukken van de internationale handelsstatistieken plus een aantal landbouwgoederen uit overige hoofdstukken volgens de Gecombineerde Nomenclatuur coderingssystematiek (GN). Bij landbouwgoederen gaat het dus enerzijds om primaire agrarische producten, zoals varkens, appels, bloemen, bloembollen en tomaten, en anderzijds om verwerkte (secundaire) producten, zoals kaas, frites, chocolade of bewerkingen van groente en fruit.

Naast de handel in landbouwgoederen is in deze publicatie ook de handel in landbouwgerelateerde goederen uitgelicht. Dat zijn (niet eetbare) goederen die geproduceerd worden ten behoeve van de landbouwsectoren in binnen- of buitenland, de zogenaamde tertiaire of landbouwgerelateerde goederen. Het gaat hierbij bijvoorbeeld om landbouwmachines, meststoffen en machines voor de voedingsmiddelenindustrie. Er zijn alleen goederen geselecteerd die enkel aan de agrarische sectoren kunnen worden toegeschreven. Het gebruik van drones in de agrarische sector kan momenteel bijvoorbeeld niet inzichtelijk worden gemaakt in de internationale handelsstatistiek. Drones kunnen immers door allerlei sectoren worden ingezet.

Door gebruik te maken van de Gecombineerde Nomenclatuur coderingssystematiek, kunnen nagenoeg dezelfde productgroepen worden betrokken uit de databronnen die in deze publicatie zijn gebruikt: CBS, Eurostat/Comext, Destatis en de Verenigde Naties/Comtrade. Meer informatie over de gehanteerde definitie is te vinden in bijlage 2 .

Nederland is al vele jaren een belangrijke wereldspeler in de agribusiness en de tweede landbouwgoederenexporteur van de wereld. Al jaren is circa $73 \%$ van de door Nederland geëxporteerde landbouwgoederen van Nederlandse makelij. Het overige deel betreft wederuitvoer ${ }^{3}$ van geïmporteerde goederen. Deze goederen worden, al dan niet na een lichte bewerking in

3 Zie voor het belang van de wederuitvoer onder andere de publicaties 'Bijdrage wederuitvoer aan bbp in twintig jaar verdubbeld' (CBS, 2016d), 'Het Rotterdam effect' (Kuipers, 2018) en 'Kenmerken van wederuitvoerbedrijven (Kuypers et al., 2012). 
Nederland, weer uitgevoerd naar het buitenland. Het Nederlandse agrocluster geniet internationaal groot aanzien. Nederland heeft een sterke primaire sector, maar ook de toeleverende en verwerkende industrie en logistiek zijn belangrijke spelers die de agribusiness tot een succes maken.

Ontwikkelingen in andere delen van Europa of de wereld zijn van invloed op de Nederlandse landbouw en zijn handelspositie. De prijsvolatiliteit op de wereldmarkt kan groot zijn, bijvoorbeeld door het al dan niet slagen van oogsten, conflicten, boycots of andere handelsbelemmeringen. Daarnaast spelen zaken als de groei van de wereldbevolking, de toenemende vraag naar gezond voedsel en klimaatverandering een steeds belangrijkere rol op internationale markten voor landbouwproducten. Om Nederland een sterke internationale positie te laten behouden, zal er in de toekomst, naast op concurrentie op prijs en volume, moeten worden blijven ingezet op de export van kwalitatief hoogstaande en duurzame producten, kennis, innovatie en technologie. Wil Nederland een agrarisch gidsland zijn op het gebied van duurzame landbouw, dan moet Nederland een prominente rol houden in de vernieuwing van productiemethoden. 


\section{De Nederlandse handel in landbouwgoederen}

In dit hoofdstuk worden de belangrijkste trends in de landbouwexport, -import en -handelsbalans beschreven. Hoe groot is de omvang, wat is de ontwikkeling en hoe verhoudt de ontwikkeling zich tot de ontwikkeling bij niet-landbouwgoederen? Daarna wordt de focus verlegd naar landen van herkomst en bestemming.

Wat zijn de belangrijkste landen en waar zit de grootste groei? Hetzelfde wordt vervolgens gedaan voor de goederenhoofdstukken (eerste 24 en overige landbouw). In de laatste paragraaf wordt specifiek de focus gelegd op Duitsland, onze belangrijkste handelspartner.

\subsection{Groei landbouwexport komt bijna tot stilstand}

De omvang van de Nederlandse landbouwexport wordt voor 2018 geraamd op 90,3 miljard euro. Dat is $0,2 \%$ meer dan het definitieve cijfer voor 2017 (90,1 miljard euro $)^{4}$ en steekt schril af tegen de voorgaande twee jaren (in 2016 ruim 4\% groei en in 2017 ruim 6\% groei). Sinds het crisisjaar 2008 is slechts twee keer (in 2009 en 2015) sprake geweest van een absolute exportdaling (figuur 2.1). De geraamde landbouwexport voor 2018 ligt 38\% hoger dan de waarde in 2008. Dat komt door zowel een hoeveelheids- als een prijseffect (zie paragraaf 4.2).

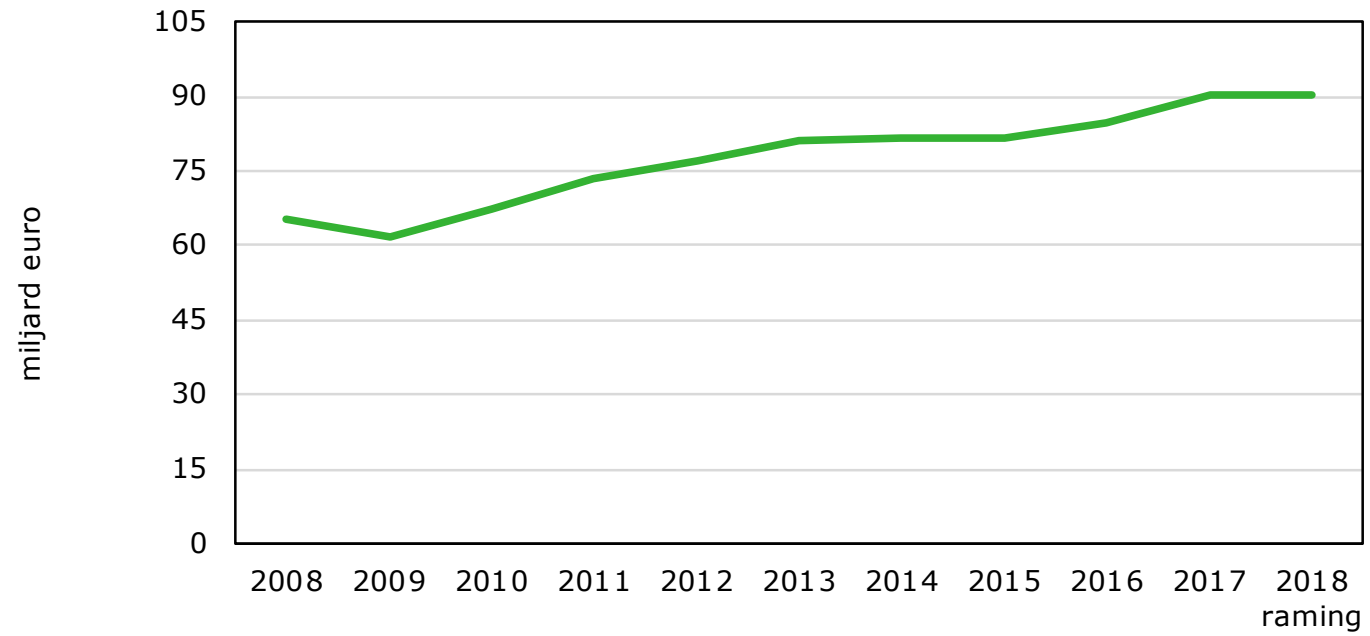

Figuur 2.1 Ontwikkeling waarde Nederlandse landbouwexport.

Bron: CBS tot en met oktober 2018, raming november - december 2018 door WUR en CBS.

Inclusief landbouwgerelateerde goederen, zoals machines voor de voedingsindustrie of meststoffen, wordt de landbouwexport geraamd op 99,5 miljard euro. Dit is 0,5\% hoger dan in 2017 (zie paragraaf 3.10).

\footnotetext{
4 Als gevolg van methodologische wijzigingen zijn de definitieve cijfers in de goederenhandelsstatistiek voor 2017 en eerdere jaren naar beneden bijgesteld en is de geraamde landbouwexport voor 2018 nu de hoogste waarde ooit, hoewel deze lager ligt dan de oorspronkelijke raming voor 2017 (voor de methodologische wijzingen). Zie verder de dataverantwoording in de bijlage.
} 


\subsubsection{Landbouwimport ook iets hoger}

Ook de invoer van landbouwgoederen wordt voor 2018 iets boven het niveau van 2017 geraamd. De import in 2018 wordt geschat op 61,4 miljard euro. Dat is 0,5\% hoger dan het definitieve cijfer van 2017 (figuur 2.2). Dat is ook hier een fors lagere groei dan in 2017, met toen $8 \%$ groei ten opzichte van 2016. De landbouwimport is sinds 2008, net als de export, vrijwel onafgebroken doorgegroeid. Alleen in 2009 en in 2014 was er sprake van een daling in vergelijking met het voorgaande jaar. De waarde van de voor 2018 geraamde landbouwimport ligt maar liefst 48\% hoger dan in 2008.

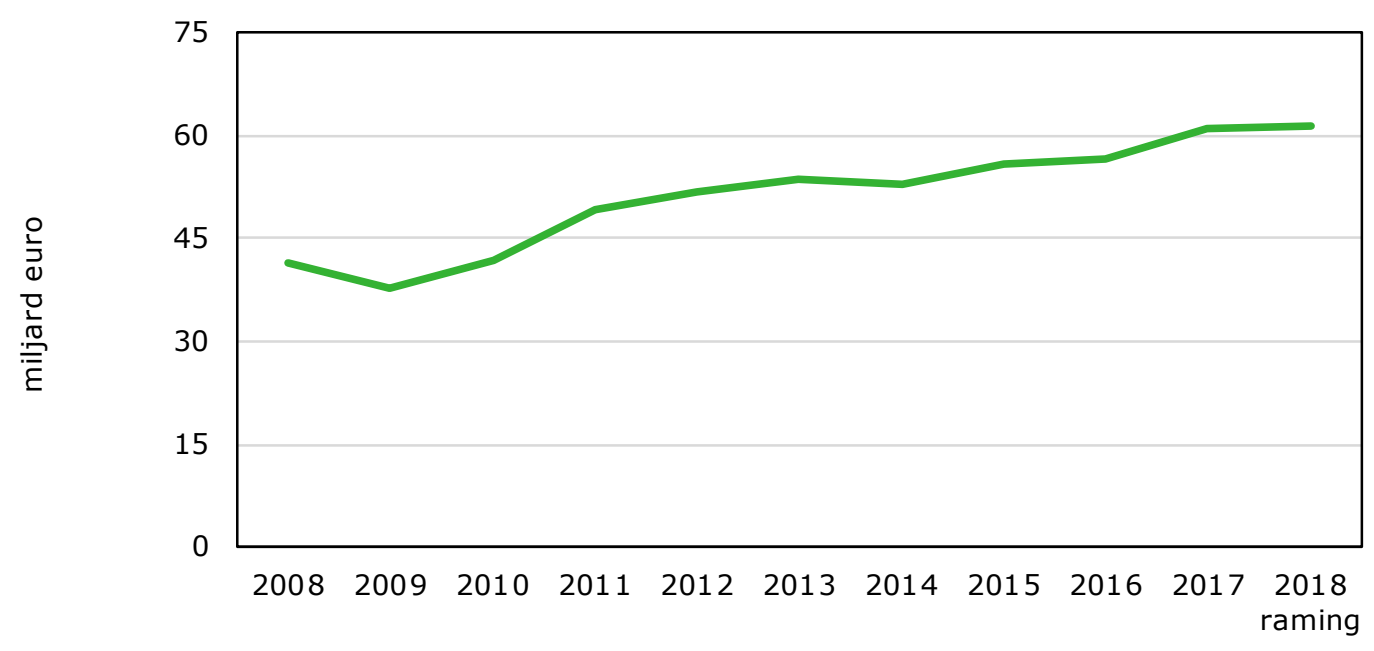

Figuur 2.2 Ontwikkeling waarde Nederlandse landbouwimport.

Bron: CBS tot en met oktober 2018, raming november - december 2018 door WUR en CBS.

\subsubsection{Handelsoverschot iets lager}

Door de iets sterker groeiende landbouwimport in vergelijking met de landbouwexport komt het landbouwhandelsoverschot ook iets lager $(-0,4 \%)$ uit dan in 2017 . Het handelsoverschot neemt licht af, van 28,9 naar 28,8 miljard euro (figuur 2.3). Nederland heeft daarmee sinds 2008 elk jaar een fors overschot in de handel in landbouwgoederen gekend. Het geraamde overschot voor 2018 ligt $22 \%$ hoger dan in 2008. Dat is een minder sterke groei dan de landbouwexport, doordat de import in dezelfde periode procentueel sterker groeide dan de export. Er is toch een toename, doordat de export absoluut (in miljarden euro's) sterker groeide dan de invoer.

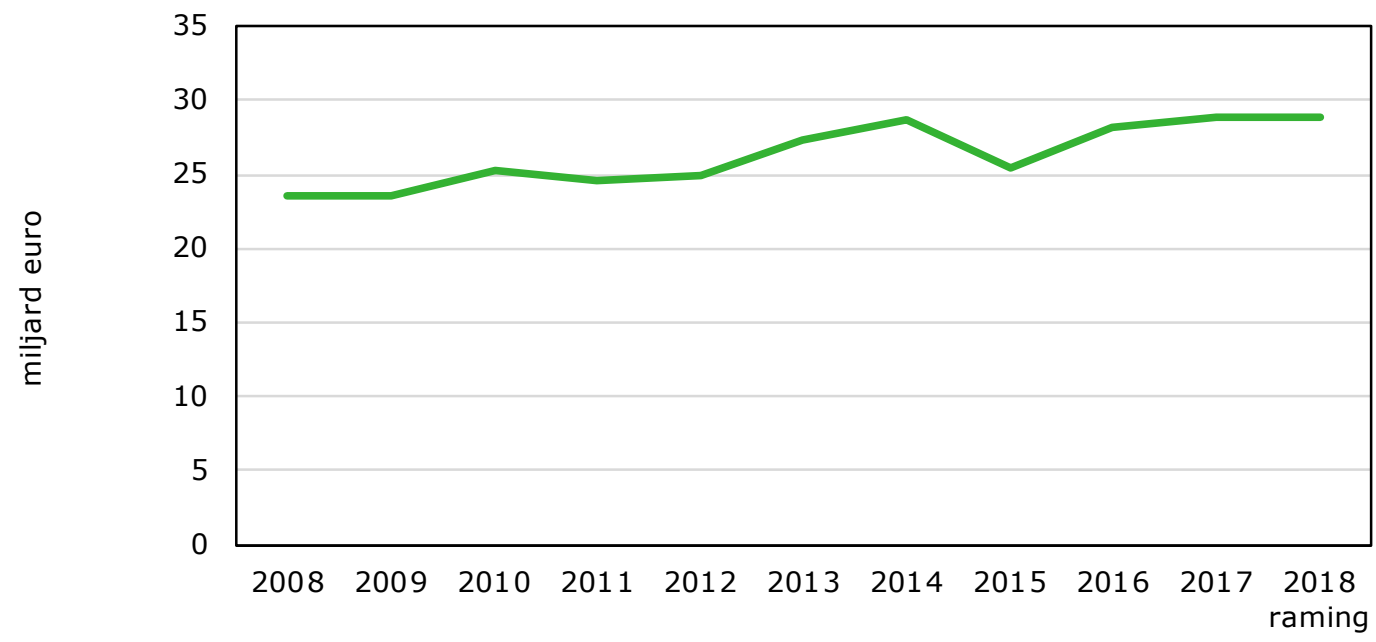

Figuur 2.3 Ontwikkeling Nederlands landbouwhandelsoverschot.

Bron: CBS tot en met oktober 2018, raming november - december 2018 door WUR en CBS. 


\subsubsection{Landbouwaandeel in totale handelsoverschot groeit}

In vergelijking met 2017 is zowel de landbouwexport als de landbouwimport minder belangrijk geworden in het totale Nederlandse goederenpakket. Dat komt doordat de handel in nietlandbouwgoederen een stuk sterker steeg dan de handel in agrarische goederen. Het aandeel van de landbouw in de totale goederenexport nam af van 19,3\% in 2017 naar 18,2\% in 2018. Bij de import daalt het landbouwaandeel van 15,0\% in 2017 naar 13,8\% in 2018. In de afgelopen tien jaar zijn de landbouwaandelen vrij stabiel gebleven (figuur 2.4).

Het landbouwhandelsoverschot laat een opvallende ontwikkeling zien als we deze vergelijken met het totale geraamde goederenhandelsoverschot van Nederland. Na een vrijwel continue afname van het landbouwaandeel van 68\% in 2008 naar 49\% in 2017, schiet het aandeel in 2018 weer omhoog naar $58 \%$. De reden is dat het totale goederenhandelsoverschot dit jaar fors lager zal uitkomen dan in 2017. Deze daling komt voor het overgrote deel door een sterk groeiend tekort in de handel in minerale brandstoffen. Daarbij speelt een toenemende import van aardgas en ruwe aardolie een grote rol (zie ook CBS, 2018a).

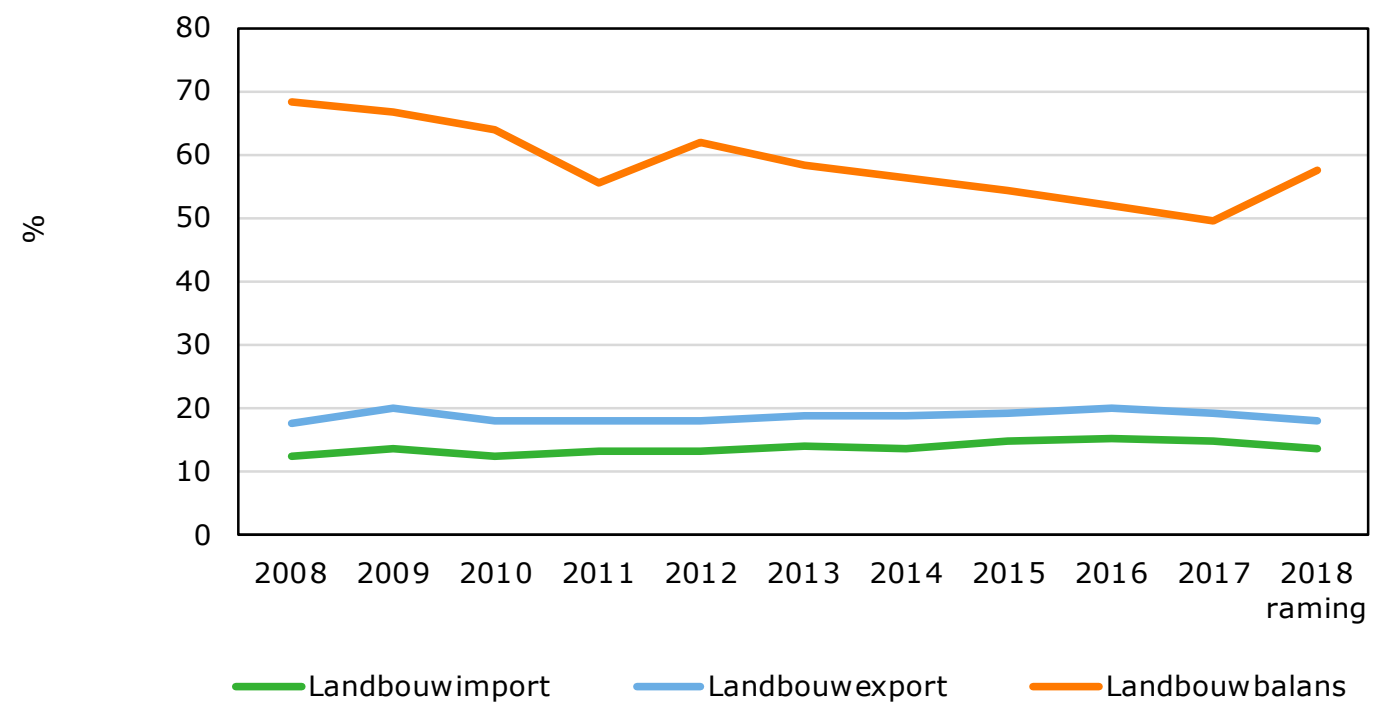

Figuur 2.4 Ontwikkeling landbouwaandeel in totale goederenhandel. Bron: CBS tot en met oktober 2018, raming november - december 2018 door WUR en CBS.

\subsection{Ruim een derde landbouwexport naar buurlanden}

De meeste landbouwexport gaat in 2018, net als alle voorgaande jaren, naar onze buurlanden: 22,8 miljard euro naar Duitsland en 10,2 miljard euro naar België (figuur 2.5). Dit betreft 36\% van de totale Nederlandse landbouwexport (Duitsland 25\% en België 11\%). Daarna volgen als belangrijkste afnemers het Verenigd Koninkrijk, Frankrijk, Italië, Spanje, de Verenigde Staten, China, Polen en Zweden. De gehele top tien is goed voor maar liefst $72 \%$ van de totale export, hetzelfde percentage als in 2017.

In de top tien van bestemmingen staan dezelfde namen als in 2017 en ook de volgorde is niet veranderd. Het aantal EU-landen (nog inclusief het Verenigd Koninkrijk) in de top tien is zeer hoog. Alleen de Verenigde Staten (zevende) en China (achtste) zijn bestemmingen buiten de EU. 


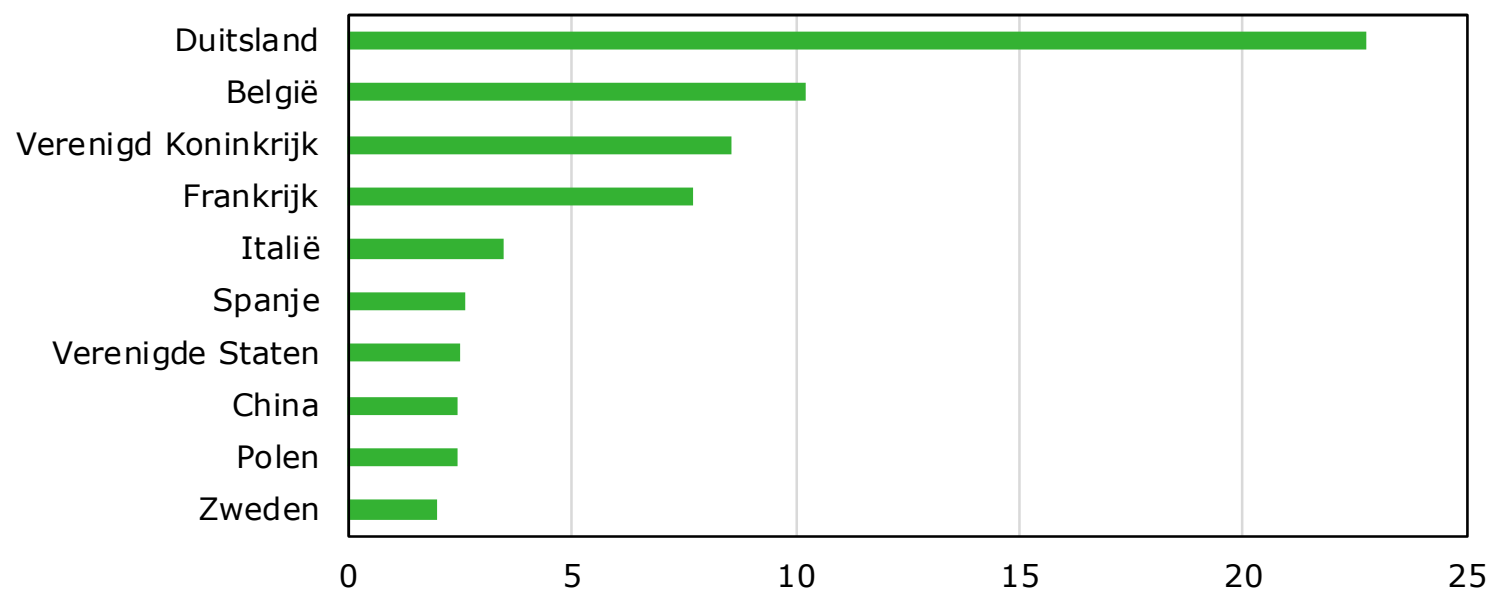

miljard euro

Figuur 2.5 Belangrijkste afnemers van de Nederlandse landbouwexport, 2018.

Bron: CBS tot en met oktober 2018, raming november - december 2018 door WUR en CBS.

\subsubsection{Grootste absolute afname in export naar Duitsland}

De grootste absolute afnames in de Nederlandse landbouwexport betreffen de topbestemmingen Duitsland (-310 miljoen euro, zie paragraaf 2.4), Frankrijk (-97 miljoen euro) en het Verenigd Koninkrijk (-72 miljoen euro) (figuur 2.6). Bij al deze bestemmingen gaat het om procentueel geringe afnames van circa $1 \%$ ten opzichte van 2017. De grootste afname bij de export naar het Verenigd Koninkrijk betreffen varkensvlees, natuurlijke vetten of oliën en dranken (zie ook CBS, 2018b).

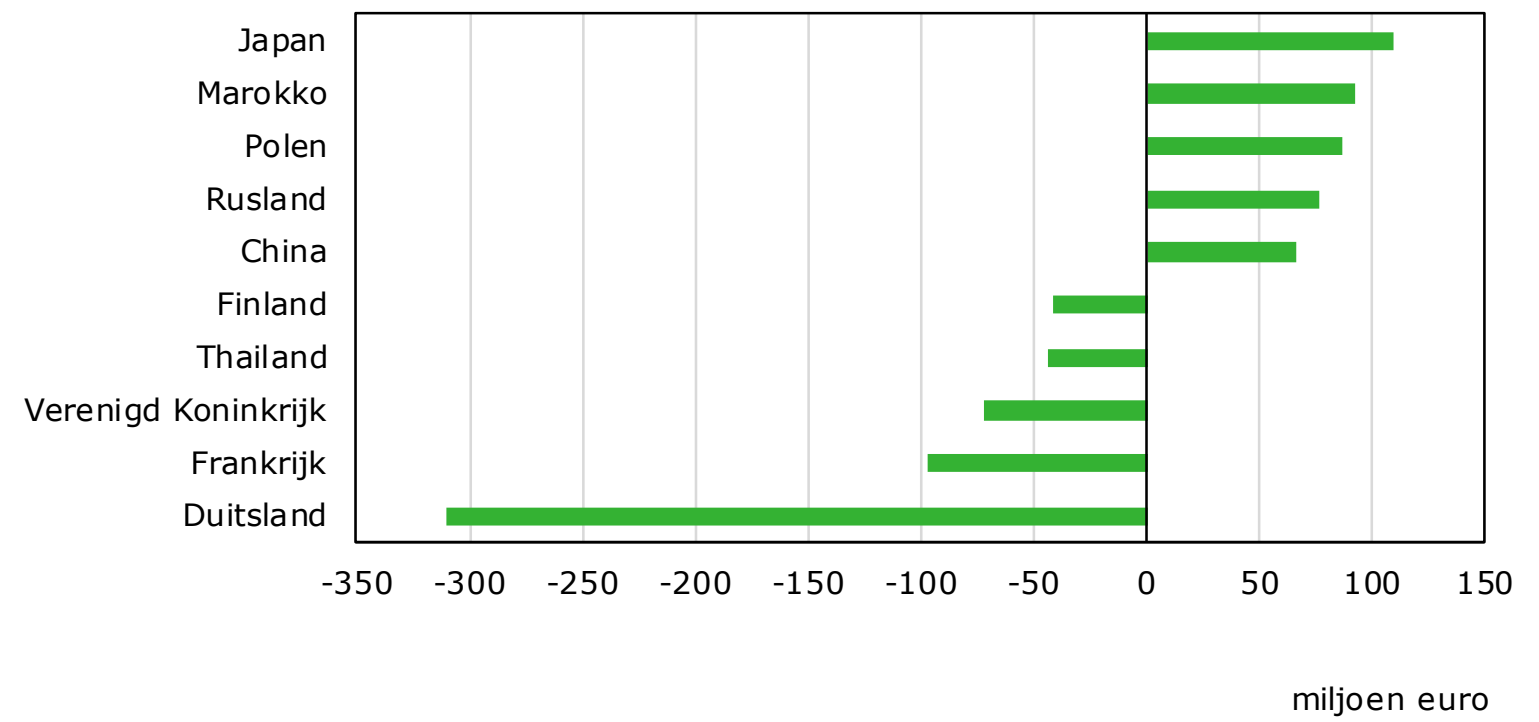

Figuur 2.6 Top 5 stijgers en dalers in de Nederlandse landbouwexport, 2017-2018.

Bron: CBS tot en met oktober 2018, raming november - december 2018 door WUR en CBS.

Aan de positieve kant komen Japan ( +110 miljoen euro), Marokko (+93 miljoen euro), Polen (+86 miljoen euro), Rusland ( +77 miljoen euro) en China (+66 miljoen euro) naar boven. In het geval van Marokko $(+36 \%)$ en Japan $(+17 \%)$ gaat het om aanzienlijke groeipercentages. De exportgroei naar Japan gaat met name om varkensvlees en dranken. De exportgroei naar Marokko betreft voor de helft natuurlijke vetten en oliën. Polen $(+3 \%)$, Rusland $(+6 \%)$ en China groeien procentueel een stuk minder. Fruit (naar Polen), bereidingen van graan, meel en melk (China, Rusland) en snijbloemen 
(Rusland) zijn hier de meest prominente stijgers. Babymelkpoeder is als zuivelbereiding zelfs verantwoordelijk voor de gehele exportgroei naar China en is inmiddels het belangrijkste Nederlandse exportproduct, inclusief niet-landbouwgoederen, richting China (CBS, 2018c).

\subsubsection{Buurlanden goed voor bijna een derde landbouwimport}

Net als bij de export zijn de buurlanden toonaangevend als landbouwleveranciers bij de import. De landbouwimport uit Duitsland wordt geraamd op 11,4 miljard euro (18,5\%) en daarnaast komt 8,6 miljard (14,0\%) uit België (figuur 2.7). De percentages zijn vrijwel gelijk aan vorig jaar. Frankrijk, Brazilië, de Verenigde Staten, Spanje, het Verenigd Koninkrijk, Polen, Italië en Ivoorkust vullen de top tien van belangrijkste landbouwleveranciers aan. De samenstelling van de top tien is bijna dezelfde als vorig jaar en ook het gezamenlijke aandeel is vergelijkbaar (licht gegroeid van 62 naar 62,6\%). De importwaarde van bonen in de cacao-industrie nam toe, de importwaarde van palmolie nam af. Daardoor kwam Ivoorkust in de top tien van importlanden en zakte Indonesië daaruit weg.

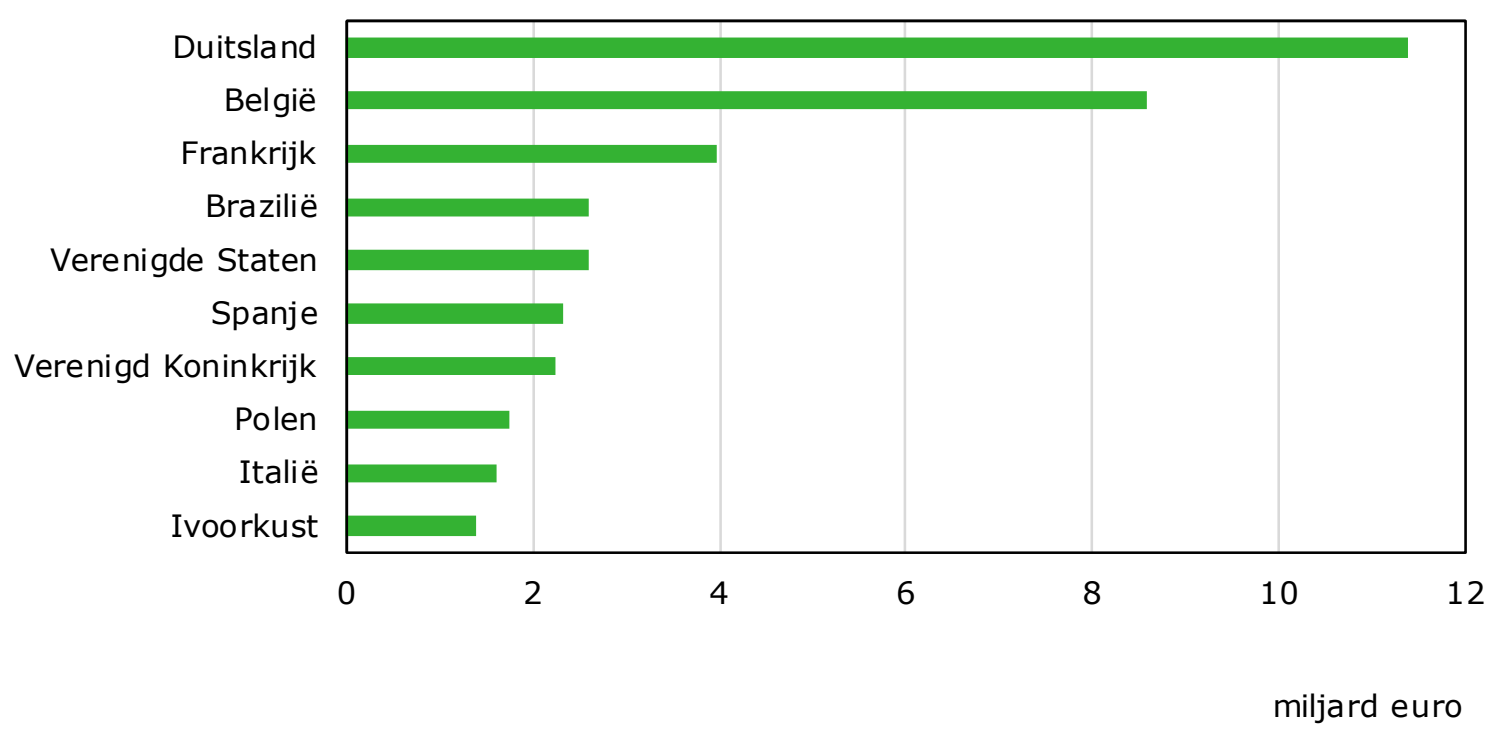

Figuur 2.7 Belangrijkste leveranciers van de Nederlandse landbouwimport, 2018.

Bron: CBS tot en met oktober 2018, raming november - december 2018 door WUR en CBS.

\subsubsection{Sterke groei import uit Frankrijk}

De grootste absolute toename bij de import van landbouwgoederen betreft de invoer uit Frankrijk. Deze nam toe met 350 miljoen euro, oftewel een groei van 10\% in vergelijking met 2017 (figuur 2.8). Het gaat hierbij met name om een groeiende waarde van de graaninvoer. Na Frankrijk volgen de Verenigde Staten (+193 miljoen euro; 8\%; sojabonen), Polen (+138 miljoen; $9 \%$; divers), Thailand (+104 miljoen; $22 \%$; vlees) en België (+91 miljoen; $1 \%$; dranken).

De invoer uit enkele landen buiten de EU nam sterk af: Indonesië (-341 miljoen euro; $-21 \%$; palmolie), Oekraïne (-169 miljoen; -14\%; natuurlijke oliën), Argentinië (-138 miljoen; -15\%; pinda's, veevoer), Australië (-99 miljoen; -23\%; kool- en raapzaad) en Brazilië (-93 miljoen; -3\%; vis- en vleesbereidingen). 


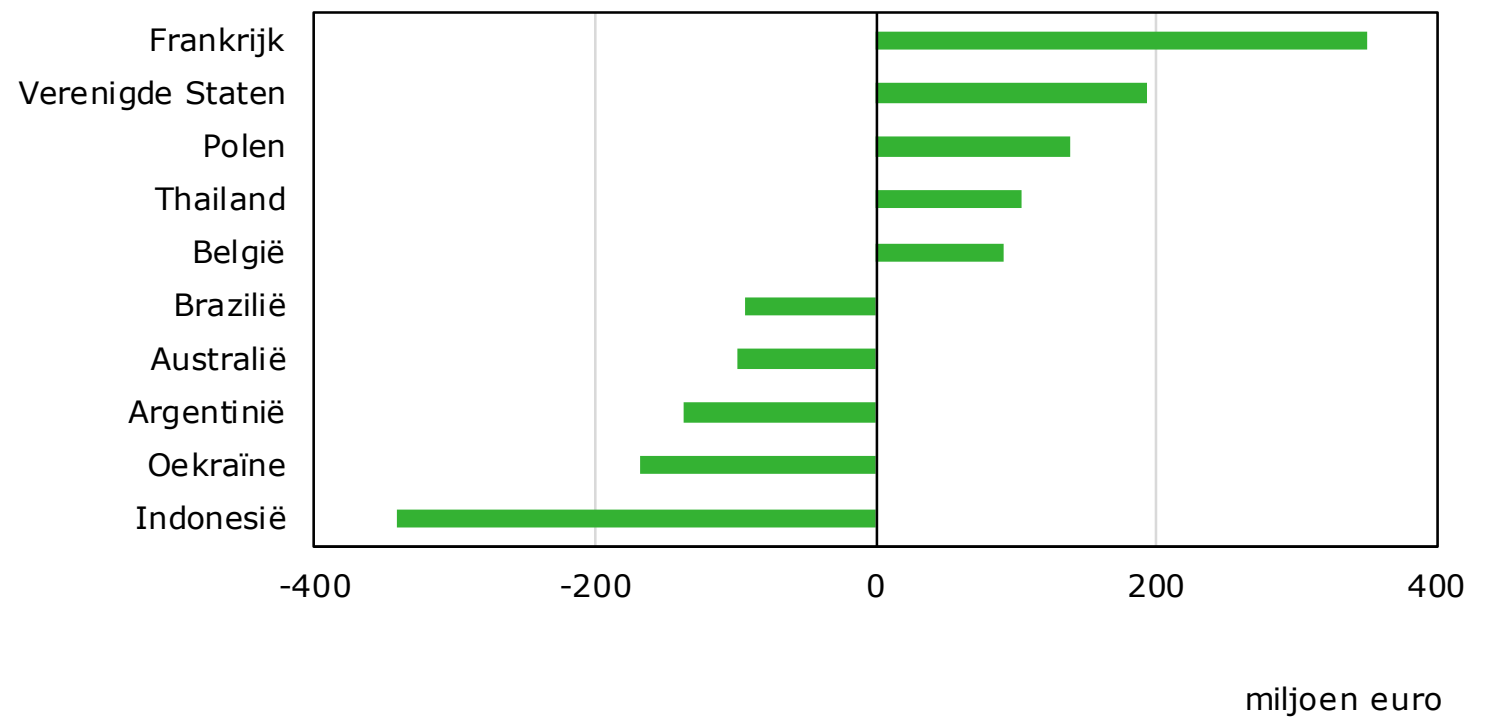

Figuur 2.8 Top 5 stijgers en dalers in de Nederlandse landbouwimport, 2017-2018.

Bron: CBS tot en met oktober 2018, raming november - december 2018 door WUR en CBS.

\subsection{Divers beeld bij de landbouwgoederenhoofdstukken}

In deze paragraaf worden de ontwikkeling van de export en import van 24 landbouwgoederen in Nederland in 2018 beschreven. De landbouwgoederen zijn hieronder gerangschikt naar afnemend aandeel in de exportwaarde. Met een aandeel van ruim $10 \%$ in de landbouwexportwaarde was sierteelt de belangrijkste productgroep in 2018. Bij de import had fruit het hoogste aandeel.

\subsubsection{Meer export en import van sierteeltproducten}

Bij sierteeltproducten gaat het om bloembollen, snijbloemen, boomkwekerijproducten en overige bloemen en planten. De export van sierteeltproducten nam in 2018 met 3\% toe tot een exportwaarde van 9,2 miljard euro (tabel 2.1). Van de sierteeltproducten ging $29 \%$ naar Duitsland, $12 \%$ naar het Verenigd Koninkrijk en 10\% naar Frankrijk. De exportwaarde naar Duitsland steeg met 4,5\%, terwijl de export naar het Verenigd Koninkrijk met 1\% daalde. De toename van de exportwaarde naar Duitsland hing vooral samen met de toegenomen export van overige snijbloemen bestemd voor o.a. boeketten. Sinds de Brexit-stemming in 2016 is de koers van het pond drastisch gedaald. Prijsverhogingen op de Britse markt leidden ertoe dat consumenten meer goedkopere bloemen kochten, waardoor de export naar het Verenigd Koninkrijk voor Nederlandse exporteurs moeizamer werd. Onzeker is hoe de export naar het Verenigd Koninkrijk in de toekomst zal verlopen. Nederlandse exporteurs hebben zorgen over tijdige afwikkeling van grensprocedures en fytosanitaire eisen. De export naar het Verenigd Koninkrijk is voor 2018 geraamd op 514 miljoen euro. Dit is ruim $2 \%$ lager ten opzichte van de export in 2017 (zie paragraaf 3.4). Naast snijbloemen zijn bloembollen en boomkwekerijproducten belangrijke exportproducten (zie paragraaf 3.5 en paragraaf 3.9). Van de totale geëxporteerde sierteeltproducten was $88 \%$ van Nederlandse makelij. Bij de export naar Duitsland was het aandeel goederen van Nederlandse makelij lager (83\%).

De importwaarde van sierteeltproducten bedroeg in 2018 circa 2,1 miljard euro en nam met $2 \%$ toe. De import kwam vooral uit Duitsland (16\%), Kenia (16\%) en België (12\%). Van deze landen nam alleen de import vanuit Duitsland toe ten opzichte van 2017. De grotere import uit Duitsland was vooral zichtbaar bij buitenplanten, bloeiende potplanten en bewerkte bloemen. Uit Kenia is de importwaarde van rozen afgenomen. 
Tabel 2.1 Nederlandse handel in sierteeltproducten (GN-06).

\begin{tabular}{|c|c|c|}
\hline & 2018 (raming) & Mutatie t.o.v. 2017 \\
\hline Totale exportwaarde (miljard euro) & 9,2 & $3,3 \%$ \\
\hline Waarvan Nederlandse makelij & $88 \%$ & \\
\hline Totale importwaarde (miljard euro) & 2,1 & $1,9 \%$ \\
\hline Aandeel in de landbouwimport & $2,4 \%$ & \\
\hline Duitsland & 2.638 & $5 \%$ \\
\hline Verenigd Koninkrijk & 1.066 & $-1 \%$ \\
\hline Frankrijk & 949 & $2 \%$ \\
\hline \multicolumn{3}{|c|}{ Belangrijkste herkomstlanden import (miljoen euro) } \\
\hline
\end{tabular}

Bron: CBS tot en met oktober 2018, raming november - december 2018 door WUR en CBS.

\subsubsection{Minder export van zuivel en eieren, groei bij import}

In 2018 bedroeg de export van zuivel en eieren 8,5 miljard euro - 2,4\% lager dan in 2017 (tabel 2.2). Dit kwam door een daling van de export van kaas. De export van consumptie-eieren nam toe, maar deze toename was kleiner dan de exportdaling bij de zuivel (zie paragraaf 3.6 en paragraaf 3.8). Duitsland is met $28 \%$ het belangrijkste afzetland, gevolgd door België (17\%) en Frankrijk (11\%). De exportwaarde van zuivel en eieren naar Duitsland is met $2 \%$ afgenomen, maar naar Frankrijk met $4 \%$ toegenomen. De afname in exportwaarde naar Duitsland wordt bepaald door een lagere export van kaas voor verwerking en van Goudse kaas (vetgehalte $<=40 \%$ ). De afname van de Nederlandse kaashandelswaarde wordt veroorzaakt door lagere exportvolumes. Enkele kaassoorten, zoals Goudse en Edammer kaas, zijn in 2018 lager geprijsd, maar over de hele linie is de oorzaak van de lagere exportwaarde het volume. De exportwaarde van zuivel en eieren was voor $82 \%$ afkomstig van goederen van Nederlandse makelij. Bij de export naar Duitsland was het aandeel goederen van Nederlandse makelij lager (77\%).

Tabel $2.2 \quad$ Nederlandse handel in zuivel en eieren (GN-04).

\begin{tabular}{|c|c|c|}
\hline & 2018 (raming) & Mutatie t.o.v. 2017 \\
\hline Totale exportwaarde (miljard euro) & 8,5 & $-2,4 \%$ \\
\hline Waarvan Nederlandse makelij & $82 \%$ & \\
\hline Totale importwaarde (miljard euro) & 4,2 & $6,8 \%$ \\
\hline Aandeel in de landbouwimport & $4,7 \%$ & \\
\hline Duitsland & 2.369 & $-2 \%$ \\
\hline België & 1.406 & $-1 \%$ \\
\hline Frankrijk & 906 & $4 \%$ \\
\hline \multicolumn{3}{|c|}{ Belangrijkste herkomstlanden import (miljoen euro) } \\
\hline
\end{tabular}

Bron: CBS tot en met oktober 2018, raming november - december 2018 door WUR en CBS.

In 2018 bedroeg de import van zuivel en eieren 4,2 miljard euro een toename van bijna $7 \%$. Nederland importeerde vooral uit Duitsland (38\%) en België (21\%). De toegenomen import uit Duitsland ten opzichte van 2017 houdt verband met de import van melk en room. De toename van import uit België hangt samen met de hogere importwaarde van melk en room en consumptie-eieren. De import uit Ierland van boter (vetgehalte tussen $80 \%$ en $85 \%$ ) en van melk en room (vetgehalte tussen $1,5 \%$ en $27 \%$ ) nam relatief sterk toe. 


\subsubsection{Minder export van vlees, groei bij import}

Nederland exporteerde in 2018 voor ruim 8 miljard euro aan vlees en eetbare slachtbijproducten. Dit was 1,4\% minder dan in 2017 (tabel 2.3). Rundvlees heeft het hoogste aandeel in de export van vlees. Varkensvlees had een aandeel van 1,8 miljard euro in de export (zie paragraaf 3.7). Van al het vlees ging $21 \%$ naar Duitsland en $15 \%$ naar het Verenigd Koninkrijk. Frankrijk, Italië en België maken de top vijf af. Samen hadden deze landen in 2018 een aandeel van circa $60 \%$ in de totale export van vlees. De totale exportwaarde van vlees naar de belangrijkste exportbestemmingen is slechts beperkt gewijzigd. Een belangrijke daler bij de exportwaarde van vlees was China (-21\% ten opzichte van 2017). De exportwaarde van vlees is voor $89 \%$ afkomstig van goederen van Nederlandse makelij.

Nederland importeerde in 2018 voor 3,9 miljard euro aan vlees. Dat is een toename van bijna $2 \%$ ten opzichte van 2017. De import kwam vooral uit Duitsland (25\%) en België (13\%). De afgenomen vleesimport uit Duitsland hing vooral samen met een importdaling van verse of gekoelde vleessoorten. Uit Brazilië nam vooral de importwaarde van gezouten, gepekeld, gedroogd of gerookt vlees af.

Tabel 2.3 Nederlandse handel in vlees (GN-02).

\begin{tabular}{|c|c|c|}
\hline & 2018 (raming) & Mutatie t.0.v. 2017 \\
\hline Totale exportwaarde (miljard euro) & 8,1 & $-1,4 \%$ \\
\hline Waarvan Nederlandse makelij & $89 \%$ & \\
\hline Totale importwaarde (miljard euro) & 3,9 & $1,8 \%$ \\
\hline Aandeel in de landbouwimport & $4,3 \%$ & \\
\hline Duitsland & 1.710 & $1 \%$ \\
\hline Verenigd Koninkrijk & 1.231 & $-1 \%$ \\
\hline Frankrijk & 745 & $2 \%$ \\
\hline \multicolumn{3}{|c|}{ Belangrijkste herkomstlanden import (miljoen euro) } \\
\hline
\end{tabular}

Bron: CBS tot en met oktober 2018, raming november - december 2018 door WUR en CBS.

\subsubsection{Vergelijkbare export van groenten, krimp bij import}

Tomaten, paprika's en komkommers zijn de belangrijkste exportproducten bij de groenten. De waarde van de export van kas- en vollegrondgroenten bedroeg 6,6 miljard euro in 2018. Dit is vergelijkbaar met het niveau van 2017 (tabel 2.4). De verschillen tussen de groenten zijn echter groot. De export van tomaten nam af en de export van komkommers nam fors toe. Bij de tomaten geldt dat al sinds januari 2018 de internationale markt in het teken staat van stagnerende vraag en veel aanbod, met als resultaat lage prijzen (zie paragraaf 3.4). Voor het totaal aan groenten waren in 2018 de drie belangrijkste exportbestemmingen Duitsland (34\%), het Verenigd Koninkrijk (13\%) en België (11\%). De export naar deze landen nam in lichte mate toe, ondanks een beperkte daling van de totale exportwaarde van groenten. De exportwaarde van groenten naar België nam vooral toe door een hogere exportwaarde van verse of gekoelde wortelen en rapen. Bijna 85\% van de export (5,5 miljard euro) wordt in Europa afgezet. Van de totale geëxporteerde groenten is $84 \%$ van Nederlandse makelij. Bij de export naar Duitsland was het aandeel goederen van Nederlandse makelij hoger (87\%).

De importwaarde van groenten bedroeg 2,3 miljard euro in 2018. Dat is een daling van 4,5\% ten opzichte van 2017. Spanje blijft het belangrijkste herkomstland van de import (26\%), maar de import daalde in 2018 met $12 \%$ ten opzichte van 2017. Andere belangrijke herkomstlanden in de import zijn België (18\%), Duitsland (15\%) en Frankrijk (7\%). De import uit België en Frankrijk nam beperkt toe. Uit Spanje nam de importwaarde van verse/gekoelde tomaten, paprika en komkommers duidelijk af. 
Tabel 2.4 Nederlandse handel in groenten (GN-07).

\begin{tabular}{|c|c|c|}
\hline & 2018 (raming) & Mutatie t.0.v. 2017 \\
\hline Totale exportwaarde (miljard euro) & 6,6 & $-0,2 \%$ \\
\hline Waarvan Nederlandse makelij & $84 \%$ & \\
\hline Totale importwaarde (miljard euro) & 2,3 & $-4,5 \%$ \\
\hline Aandeel in de landbouwimport & $2,6 \%$ & \\
\hline Duitsland & 2.241 & $2 \%$ \\
\hline Verenigd Koninkrijk & 905 & $5 \%$ \\
\hline België & 721 & $8 \%$ \\
\hline \multicolumn{3}{|c|}{ Belangrijkste herkomstlanden import (miljoen euro) } \\
\hline
\end{tabular}

Bron: CBS tot en met oktober 2018, raming november - december 2018 door WUR en CBS.

\subsubsection{Meer export en import van fruit}

Druiven, avocado's ${ }^{5}$, bananen, peren en appels zijn de belangrijkste exportproducten bij het fruit. De waarde van de Nederlandse export van fruit bedroeg 6 miljard euro in 2018. Dit is een toename van ruim 8\% ten opzichte van 2017 (tabel 2.5). Van het fruit ging 37\% naar Duitsland, op lange afstand gevolgd door België (10\%), Frankrijk (8\%) en het Verenigd Koninkrijk (6\%). De export naar de eerste drie landen steeg in 2018 met ruim 14\%, terwijl de export naar het Verenigd Koninkrijk daalde met $5 \%$. De exportwaarde van fruit naar Duitsland nam met name toe door verse appels en tafeldruiven. Naar België nam vooral de export van verse bananen en verse appels toe. Ook naar Frankrijk nam de exportwaarde van verse appels duidelijk toe. De exportgroei bij de appels was vooral te danken aan de lage appeloogst in 2017 elders in Europa, maar zeker ook in Duitsland: door de lage Duitse productie kwam op de Duitse markt ruimte voor Nederlandse appels. De exportwaarde naar de 28 Europese landen steeg met ruim 9\% ten opzichte van 2017 (zie paragraaf 3.1). Het geëxporteerde fruit, in waarde, was in 2018 voor $23 \%$ van Nederlandse makelij. Dit aandeel is veel lager dan bij de andere productgroepen. Een belangrijk deel van de export betreft wederuitvoer, zoals avocado's, druiven, mango's en bananen.

Tabel 2.5 Nederlandse handel in fruit (GN-08).

\begin{tabular}{lrr} 
& 2018 (raming) & Mutatie t.0.v. 2017 \\
Totale exportwaarde (miljard euro) & $\mathbf{6 , 0}$ & $\mathbf{8 , 5} \%$ \\
\hline Waarvan Nederlandse makelij & $23 \%$ & $6 \%$ \\
\hline Aandeel in de landbouwexport & $\mathbf{6 , 2}$ & $6,9 \%$ \\
\hline Totale importwaarde (miljard euro) & $\mathbf{6 , 7} \%$ \\
\hline Aandeel in de landbouwimport & 2.202 & 588 \\
\hline Belangrijkste exportbestemmingen (miljoen euro) & 471 \\
\hline Duitsland & $14 \%$ \\
\hline België & $15 \%$ \\
\hline Frankrijk & $17 \%$ \\
\hline Belangrijkste herkomstlanden import (miljoen euro) & 676 \\
\hline Zuid-Afrika & 591 \\
\hline Spanje & 439 \\
\hline Peru & $7 \%$ \\
\hline
\end{tabular}

Bron: CBS tot en met oktober 2018, raming november - december 2018 door WUR en CBS.

\footnotetext{
5 Zie ook het artikel: Nederland tweede avocado-importeur ter wereld (CBS, 2017a).
} 
De import van fruit bedroeg 6,2 miljard euro in 2018. Dat is een toename van bijna $7 \%$ ten opzichte van 2017. Fruit is daarmee het belangrijkste importproduct binnen de landbouwgoederen. Vooral de importwaarde van bananen en druiven steeg in 2018. De import was bijna gelijk aan de export van fruit. De belangrijke herkomstlanden in de import zijn Zuid-Afrika (11\%), Spanje (7\%), België (7\%) en Chili (7\%). De toegenomen importwaarde uit Zuid-Afrika had voor het grootste deel betrekking op tafeldruiven. Uit Spanje nam de importwaarde van frambozen en van verse of gedroogde avocado's toe. Uit Peru nam de importwaarde van tafeldruiven toe, terwijl de importwaarde van verse of gedroogde avocado's sterk afnam.

\subsubsection{Meer export en import van dranken}

De exportwaarde van dranken was met 5,2 miljard euro in 2018 ruim $1 \%$ hoger dan het niveau in 2017 (tabel 2.6). De belangrijkste exportproducten zijn bier en sterke dranken. Met een aandeel van $15 \%$ waren de Verenigde Staten de belangrijkste exportbestemming, gevolgd door het Verenigd Koninkrijk (13\%), Duitsland (11\%) en België (10\%). De export naar deze Europese landen daalde met name voor het Verenigd Koninkrijk (-8\%; onder andere van niet-gedenatureerd ethylalcohol). Van het totaal aan geëxporteerde dranken is $87 \%$ van Nederlandse makelij. Bij de export naar Duitsland was het aandeel goederen van Nederlandse makelij lager (57\%).

In 2018 bedroeg de waarde van de import van dranken 3,7 miljard euro. Dat is ruim $2 \%$ hoger dan in 2017. Bij de import zijn de belangrijkste herkomstlanden België (21\%), Duitsland (20\%) en Frankrijk (15\%). De toename van de import uit België is zichtbaar bij een breed scala aan producten (bier, mineraalwater, frisdranken, etc.).

Tabel 2.6 Nederlandse handel in dranken (GN-22).

\begin{tabular}{|c|c|c|}
\hline & 2018 (raming) & Mutatie t.o.v. 2017 \\
\hline Totale exportwaarde (miljard euro) & 5,2 & $1,2 \%$ \\
\hline Waarvan Nederlandse makelij & $75 \%$ & \\
\hline Totale importwaarde (miljard euro) & 3,7 & $2,4 \%$ \\
\hline Aandeel in de landbouwimport & $4,1 \%$ & \\
\hline VS & 786 & $1 \%$ \\
\hline Verenigd Koninkrijk & 658 & $-8 \%$ \\
\hline Duitsland & 551 & $-2 \%$ \\
\hline \multicolumn{3}{|c|}{ Belangrijkste herkomstlanden import (miljoen euro) } \\
\hline
\end{tabular}

Bron: CBS tot en met oktober 2018, raming november - december 2018 door WUR en CBS.

\subsubsection{Meer export en import van bereidingen van groenten en fruit}

Onder bereidingen van groenten en fruit wordt een diverse groep producten verstaan, zoals allerlei aardappelproducten (zie paragraaf 3.2), fruitsappen, bereidingen van champignons en een typisch Nederlands product als pindakaas. In 2018 bedroeg de export van bereidingen van groenten en fruit ruim 5 miljard euro. Dat is een toename van ruim 3\% ten opzichte van 2017 (tabel 2.7). De EU is de belangrijkste afzetmarkt van deze productgroep. Van de totale exportwaarde van bereidingen van groenten en fruit ging 25\% naar Duitsland, 14\% naar Frankrijk, 13\% naar het Verenigd Koninkrijk en $10 \%$ naar België. Bij de export naar Frankrijk werd de toename met name veroorzaakt door een hogere exportwaarde van bevroren gekookte aardappelproducten en sinaasappelsap. Van het totaal aan geëxporteerde bereidingen van groenten en fruit was ongeveer $70 \%$ van Nederlandse makelij. Bij de exportwaarde naar Duitsland was het aandeel goederen van Nederlandse makelij lager (62\%). 
In 2018 bedroeg de import 2,8 miljard euro, 4,7\% hoger dan in 2017. De producten kwamen vooral uit Brazilië (16\%), België (15\%) en Duitsland (15\%). De groei bij de importwaarde uit Brazilië werd bepaald door de importtoename van sinaasappelsap.

Tabel 2.7 Nederlandse handel in bereidingen van groenten en fruit (GN-20).

\begin{tabular}{lrr} 
& $\mathbf{2 0 1 8}($ raming) & Mutatie t.0.V. 2017 \\
\hline Totale exportwaarde (miljoen euro) & $\mathbf{5 , 2} \%$ \\
\hline Waarvan Nederlandse makelij & $70 \%$ & $5,6 \%$ \\
\hline Aandeel in de landbouwexport & $\mathbf{2 , 8}$ & $3,1 \%$ \\
\hline Totale importwaarde (miljard euro) & $\mathbf{4 , 7} \%$ \\
\hline Aandeel in de landbouwimport & 1.283 & 707 \\
\hline Belangrijkste exportbestemmingen (miljoen euro) & 694 \\
\hline Duitsland & $-2 \%$ \\
\hline Frankrijk & $6 \%$ \\
\hline Verenigd Koninkrijk & $-3 \%$ \\
\hline Belangrijkste herkomstlanden import (miljoen euro) & 459 \\
\hline Brazilië & 432 \\
\hline België & 417 \\
\hline Duitsland & $12 \%$ \\
\hline
\end{tabular}

Bron: CBS tot en met oktober 2018, raming november - december 2018 door WUR en CBS.

\subsubsection{Meer export en import van bereidingen van graan, meel en melk}

Onder bereidingen van graan, meel en melk wordt een diverse groep producten verstaan. Belangrijke exportproducten zijn allerlei voedingsbereidingen voor baby's en jonge kinderen (zie ook CBS, 2015), koekjes, pizza's en pastaproducten. In 2018 bedroeg de totale exportwaarde van deze diverse groep producten circa 4,8 miljard euro. Dat is een forse toename van 12\% ten opzichte van 2017 (tabel 2.8). Van deze producten ging de meeste export naar China (25\%). De toename naar China betrof circa $19 \%$ (hoofdzakelijk voedingsbereidingen voor baby's, zoals melkpoeder). Andere belangrijke exportbestemmingen waren Duitsland (12\%) en België (9\%). Een opvallende stijger bij de exportwaarde is Rusland (+65\%). Van het totaal aan geëxporteerde bereidingen van graan, meel, zetmeel en melk is $83 \%$ van Nederlandse makelij. Bij de export naar Duitsland was het aandeel goederen van Nederlandse makelij lager (78\%).

De bereidingsproducten van graan, meel en melk hadden in 2018 een importwaarde van 2,5 miljard euro, een stijging van ruim $13 \%$ ten opzichte van 2017 . De belangrijkste herkomstlanden in de import waren België en Duitsland, samen goed voor 46\%. De importwaarde uit Duitsland liet in 2018 een stijging zien van $17 \%$ (voedingsbereidingen voor baby's).

Tabel $2.8 \quad$ Nederlandse handel in bereidingen van graan, meel en melk (GN-19).

\begin{tabular}{lrr} 
& 2018 (raming) & Mutatie t.0.v. 2017 \\
Totale exportwaarde (miljard euro) & $\mathbf{4 , 8}$ & $\mathbf{1 2}, \mathbf{0} \%$ \\
\hline Waarvan Nederlandse makelij & $5,4 \%$ & $\mathbf{2 , 5}$ \\
\hline Aandeel in de landbouwexport & $2,7 \%$ & $\mathbf{1 3 , 3} \%$ \\
\hline Totale importwaarde (miljard euro) & 1.235 \\
\hline Aandeel in de landbouwimport & 582 \\
\hline Belangrijkste exportbestemmingen (miljoen euro) & 429 \\
\hline China & $21 \%$ \\
\hline Duitsland & $4 \%$ \\
\hline België & $4 \%$ \\
\hline Belangrijkste herkomstlanden import (miljoen euro) & 589 \\
\hline België & 572 \\
\hline Duitsland & 162 \\
\hline Frankrijk & $4 \%$ \\
\hline
\end{tabular}

Bron: CBS tot en met oktober 2018, raming november - december 2018 door WUR en CBS. 


\subsubsection{Meer export en import van resten uit voedselindustrie en veevoer}

Ook dit betreft een diverse groep producten. Belangrijke exportgoederen binnen de goederengroep 'resten uit de voedselindustrie en veevoer' zijn sojaschroot, zonnebloemzaadschroot, honden- en kattenvoer, premixes voor veevoer, en palmpitschilfers. Met een exportwaarde van 4,5 miljard euro steeg de exportwaarde van resten van de voedselindustrie en veevoer in 2018 met bijna $5 \%$ ten opzichte van 2017 (tabel 2.9). Duitsland en België waren de belangrijkste exportbestemmingen, met $31 \%$ en $18 \%$, samen dus goed voor de afname van bijna $50 \%$ van de totale export binnen deze goederengroep. De export naar het Verenigd Koninkrijk ( $9 \%$ exportaandeel) is met $12 \%$ gestegen (vooral honden- en kattenvoedsel), terwijl dit bij België met $2 \%$ daalde. Van het totaal aan geëxporteerde resten uit de voedingsindustrie en veevoer was circa $68 \%$ van Nederlandse makelij. Bij de export naar Duitsland was dit vergelijkbaar (65\%.)

In 2018 bedroeg de importwaarde van resten uit de voedselindustrie en veevoer 3 miljard euro. Dat is $1,4 \%$ hoger dan in 2017. Van deze productgroep kwam 25\% uit Brazilië, $21 \%$ uit Duitsland en $12 \%$ uit België. Een belangrijke daler is de import uit Argentinië (-32\%). Dat werd in belangrijke mate veroorzaakt door een forse daling van de importwaarde van sojaschroot. De toegenomen importwaarde uit Duitsland werd met name veroorzaakt door een hogere import van raapzaadschroot en honden- en kattenvoedsel. In het laatste hoofdstuk wordt nader ingegaan op de veevoerimport en de relatie met circulariteit (zie hoofdstuk 6).

Tabel 2.9 Nederlandse handel in resten uit de voedselindustrie en veevoer (GN-23).

\begin{tabular}{lrr} 
& 2018 (raming) & Mutatie t.0.v. 2017 \\
Totale exportwaarde (miljard euro) & $\mathbf{4 , 5}$ & $\mathbf{4 , 6 \%}$ \\
\hline Waarvan Nederlandse makelij & $68 \%$ & \\
\hline Aandeel in de landbouwexport & $5,0 \%$ & $\mathbf{1 , 4 \%}$ \\
\hline Totale importwaarde (miljard euro) & $\mathbf{3 , 0}$ & \\
\hline Aandeel in de landbouwimport & $3,3 \%$ & $8 \%$ \\
\hline Belangrijkste exportbestemmingen (miljoen euro) & & $-2 \%$ \\
\hline Duitsland & 1.349 & $14 \%$ \\
\hline België & 848 & 391 \\
\hline Verenigd Koninkrijk & & $0 \%$ \\
\hline Belangrijkste herkomstlanden import (miljoen euro) & 734 & $5 \%$ \\
\hline Brazilië & 608 & $-5 \%$ \\
\hline Duitsland & 368 & \\
\hline België & 368 & \\
\hline
\end{tabular}

Bron: CBS tot en met oktober 2018, raming november - december 2018 door WUR en CBS.

\subsubsection{Minder export en import van cacao en cacaobereidingen}

Nederland exporteerde in 2018 voor bijna 4,4 miljard euro aan cacao en bereidingen van cacaoproducten. Dit is $8 \%$ lager dan het niveau van 2017 (tabel 2.10). Van de exportwaarde gaat 27\% naar Duitsland en 12\% naar België. Met Frankrijk (9\%) en het Verenigd Koninkrijk (8\%) tezamen is dit $56 \%$ van de totale export. De geëxporteerde cacao en bereidingen van cacaoproducten zijn voor $60 \%$ van Nederlandse makelij. Vooral de exportwaarde van cacaoboter, -pasta en -bonen naar de belangrijkste exportbestemmingen nam af. Dit aandeel is lager dan bij de meeste andere productgroepen. Een belangrijk deel van de export betreft dus wederuitvoer.

De importwaarde van cacao en cacaobereidingen was met 3,9 miljard euro in 2018 bijna 4\% lager dan in 2017. Het grootste deel van de importwaarde komt uit Ivoorkust (34\%). Daarnaast komt de import via België (12\%) en Duitsland (8\%) vanuit cacaoproducerende landen. De importtoename vanuit Ivoorkust betreft cacaobonen, waarbij de import van cacaobonen via België fors is afgenomen. 
Tabel 2.10 Nederlandse handel in cacao en cacaobereidingen (GN-18).

\begin{tabular}{lrr} 
& Mutatie t.0.v. 2017 \\
\hline Totale exportwaarde (miljard euro) & $\mathbf{4 , 4}$ & $\mathbf{- 8 , 2} \%$ \\
\hline Waarvan Nederlandse makelij & $60 \%$ & $4,9 \%$ \\
\hline Aandeel in de landbouwexport & $\mathbf{3 , 9}$ & $\mathbf{9}, 4 \%$ \\
\hline Totale importwaarde (miljard euro) & $\mathbf{- 3 , 8} \%$ \\
\hline Aandeel in de landbouwimport & 1.187 \\
\hline Belangrijkste exportbestemmingen (miljoen euro) & 524 \\
\hline Duitsland & 383 \\
\hline België & $-8 \%$ \\
\hline Frankrijk & $-11 \%$ \\
\hline Belangrijkste herkomstlanden import (miljoen euro) & $-8 \%$ \\
\hline Ivoorkust & 1.345 \\
\hline België & 472 \\
\hline Duitsland & 334 \\
\hline
\end{tabular}

Bron: CBS tot en met oktober 2018, raming november - december 2018 door WUR en CBS.

\subsubsection{Minder export en import van natuurlijke vetten en oliën}

De export van natuurlijke oliën en vetten was in 2018 met 4,4 miljard euro bijna 10\% lager dan in 2017. Duitsland (27\%) en België (20\%) hebben het grootste aandeel in de export, gevolgd door het Verenigd Koninkrijk (10\%) en Frankrijk (8\%). De exportwaarde naar alle belangrijke afzetlanden daalde (fors). De daling van de waarde van de export naar Duitsland en België houdt vooral verband met de trend die bij palmolie zichtbaar is. Van het totaal aan geëxporteerde natuurlijke vetten en oliën is $70 \%$ van Nederlandse makelij, terwijl dit richting Duitsland $65 \%$ is.

De import van natuurlijke oliën en vetten was met 4,5 miljard euro in 2018 groter dan de export. Natuurlijke vetten en oliën zijn daarmee één van de weinige goederengroepen binnen de definitie van landbouwgoederen met een negatief handelsbalansoverschot. De importwaarde van natuurlijke oliën en vetten daalde met $15 \%$ ten opzichte van het niveau in 2017. De import kwam vooral uit Duitsland $(17 \%)$, Indonesië $(12 \%)$, Maleisië $(9 \%)$ en België ( $8 \%)$. Hoewel de importwaarde van ruwe palmolie afnam, is palmolie nog steeds het belangrijkste importproduct binnen de goederengroep natuurlijke vetten en oliën. De meeste palmolie is afkomstig uit Indonesië en Maleisië, maar steeds meer palmolie wordt geïmporteerd uit Latijns-Amerika (zie ook CBS, 2018f). De sterke daling van de waarde van de import uit Indonesië wordt voornamelijk bepaald door de afname bij ruwe palmolie.

Tabel 2.11 Nederlandse handel in natuurlijke vetten en oliën (GN-15).

\begin{tabular}{lrr} 
& 2018 (raming) & Mutatie t.0.v. 2017 \\
\hline Totale exportwaarde (miljard euro) & $\mathbf{4 , 4}$ & $\mathbf{- 9 , 9 \%}$ \\
\hline Waarvan Nederlandse makelij & $\mathbf{7 0} \%$ & $\mathbf{4} \%$ \\
\hline Aandeel in de landbouwexport & $\mathbf{4 , 5}$ & $\mathbf{- 1 5 , 1 \%}$ \\
\hline Totale importwaarde (miljard euro) & $5,0 \%$ & 1.203 \\
\hline Aandeel in de landbouwimport & 868 & $-10 \%$ \\
\hline Belangrijkste exportbestemmingen (miljoen euro) & 412 \\
\hline Duitsland & $-10 \%$ \\
\hline België & $-11 \%$ \\
\hline Verenigd Koninkrijk & 753 \\
\hline Belangrijkste herkomstlanden import (miljoen euro) & 492 \\
\hline Duitsland & 434 \\
\hline Indonesië & $-7 \%$ \\
\hline Maleisië & $-43 \%$ \\
\hline
\end{tabular}

Bron: CBS tot en met oktober 2018, raming november - december 2018 door WUR en CBS. 


\subsubsection{Meer export en import van overige voeding}

De goederengroep 'overige voeding' is zeer divers. Het gaat onder andere om soepen, sauzen, ijsjes en samengestelde voedselbereidingen. De export van overige voedingsproducten steeg in 2018 tot 4,3 miljard euro. Dat is een stijging van 3\% ten opzichte van 2017. $16 \%$ ging naar Duitsland, $13 \%$ naar het Verenigd Koninkrijk en $10 \%$ naar België. Frankrijk is goed voor $7 \%$ van de exportafzet. Een grote stijger in de subtop is Italië $(+26 \%)$. Van de totale waarde aan geëxporteerde overige voeding is ongeveer $73 \%$ van Nederlandse makelij.

De import van overige voedingsproducten bedroeg 2,4 miljard euro in 2018 . Dat is $10 \%$ hoger dan in 2017. De belangrijkste drie herkomstlanden van de import waren Duitsland (25\%), België (17\%) en het Verenigd Koninkrijk (10\%). De importtoename uit Duitsland was zichtbaar over een breed assortiment van producten.

Tabel 2.12 Nederlandse handel in overige voeding (GN-21).

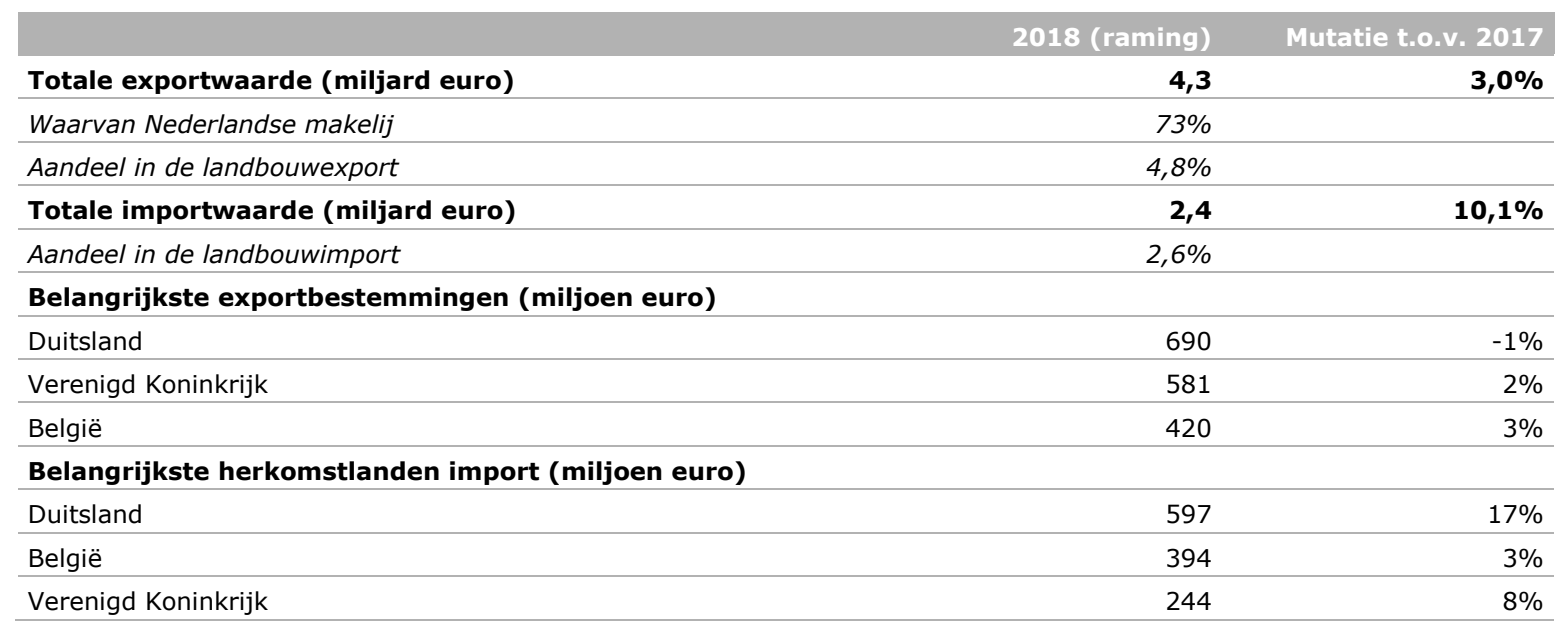

Bron: CBS tot en met oktober 2018, raming november - december 2018 door WUR en CBS.

\subsubsection{Vergelijkbare export van oliehoudende zaden en vruchten, krimp bij import}

In 2018 bedroeg de exportwaarde van oliehoudende zaden en vruchten 3,1 miljard euro. Dat is vergelijkbaar met het niveau van 2017 (tabel 2.13). Van deze producten ging 32\% naar Duitsland en ruim 7\% naar Spanje. Daarna volgt een grote groep landen met een exportaandeel van 3 tot $5 \%$. Grote stijgers zijn Mexico (44\%), België (27\%) en Spanje (25\%). De forse daling van de waarde van de export naar Duitsland werd voornamelijk veroorzaakt door minder export van koolzaad en sojabonen. Naar Spanje was de exporttoename te danken aan groentezaden. Van de totale waarde aan geëxporteerde oliehoudende zaden en vruchten was ongeveer $45 \%$ van Nederlandse makelij. Bij de exportwaarde naar Duitsland was dit aandeel slechts $13 \%$. Traditioneel vindt er bij oliehoudende zaden en vruchten veel wederuitvoer plaats.

De importwaarde van oliehoudende zaden en vruchten bedroeg in 2018 3,6 miljard euro. Dat is ruim 4\% lager dan in 2017. De belangrijkste herkomstlanden van de import zijn de Verenigde Staten (30\%) en Brazilië (12\%). De Verenigde Staten waren eveneens een grote stijger, met $24 \%$ ten opzichte van het niveau in 2017. Dit werd voornamelijk veroorzaakt door een verschuiving in herkomstlanden. De importwaarde van sojabonen uit de landen Uruguay en Paraquay daalde fors. Uit de Verenigde Staten en Oekraïne was de importwaarde juist hoger. 
Tabel 2.13 Nederlandse handel in oliehoudende zaden en vruchten (GN-12).

\begin{tabular}{|c|c|c|}
\hline & 2018 (raming) & Mutatie t.o.v. 2017 \\
\hline Totale exportwaarde (miljard euro) & 3,1 & $0,2 \%$ \\
\hline Waarvan Nederlandse makelij & $45 \%$ & \\
\hline Totale importwaarde (miljard euro) & 3,6 & $-4,3 \%$ \\
\hline Aandeel in de landbouwimport & $4,0 \%$ & \\
\hline Duitsland & 993 & $-19 \%$ \\
\hline Spanje & 232 & $27 \%$ \\
\hline Frankrijk & 172 & $0 \%$ \\
\hline \multicolumn{3}{|c|}{ Belangrijkste herkomstlanden import (miljoen euro) } \\
\hline
\end{tabular}

Bron: CBS tot en met oktober 2018, raming november - december 2018 door WUR en CBS.

\subsubsection{Meer export van vis en zeevruchten, vergelijkbaar niveau bij import}

De exportwaarde van vis en zeevruchten was met 3 miljard euro in 2018 bijna 5\% hoger dan in 2017. Duitsland en België zijn de grootste exportbestemmingen, met een aandeel van 17\% en 16\%, gevolgd door Italië (10\%) en Frankrijk (9\%) (tabel 2.14). De exporttoename naar België komt met name door verse/gekoelde zalmfilet en garnalen. Bij Duitsland was verse/gekoelde zalmfilet eveneens een belangrijke stijger. Nieuw in de top tien van de belangrijkste handelslanden is Marokko. De exportwaarde van vis en zeevruchten naar Marokko steeg met circa 25\%, met name door een hogere exportwaarde van garnalen. Van de totale waarde aan geëxporteerde vis en zeevruchten is $72 \%$ van Nederlandse makelij.

De import bedroeg 2,1 miljard euro in 2018. Dat is vergelijkbaar met het niveau van 2017. Duitsland had bij de import een aandeel van 15\%, gevolgd door België en Denemarken met elk circa $9 \%$. Turkije en Vietnam waren goed voor $7 \%$ van de import. Bij de import uit België nam vooral de waarde van garnalen af.

Tabel 2.14 Nederlandse handel in vis en zeevruchten (GN-03).

\begin{tabular}{|c|c|c|}
\hline & 2018 (raming) & Mutatie t.o.v. 2017 \\
\hline Totale exportwaarde (miljard euro) & 3,0 & $4,8 \%$ \\
\hline Waarvan Nederlandse makelij & $72 \%$ & \\
\hline Totale importwaarde (miljard euro) & 2,1 & $-0,4 \%$ \\
\hline Aandeel in de landbouwimport & $2,3 \%$ & \\
\hline Duitsland & 494 & $5 \%$ \\
\hline België & 482 & $8 \%$ \\
\hline Italië & 286 & $4 \%$ \\
\hline \multicolumn{3}{|c|}{ Belangrijkste herkomstlanden import (miljoen euro) } \\
\hline
\end{tabular}

Bron: CBS tot en met oktober 2018, raming november - december 2018 door WUR en CBS. 


\subsubsection{Minder export en import van levende dieren}

In 2018 bedroeg de export van levende dieren bijna 2 miljard euro. Dit is een afname van ruim 13\% ten opzichte van 2017 (tabel 2.15). De belangrijkste exportproducten waren kippen, varkens, paarden en melkvee. Vooral de exportwaarde van varkens en (raszuivere fok)paarden nam flink af ten opzichte van 2017. De lagere exportwaarde bij de varkens werd met name veroorzaakt door lagere prijzen van vleesvarkens en biggen. De belangrijkste exportbestemmingen voor alle levende dieren waren Duitsland (40\%), België (17\%) en de Verenigde Staten (11\%). Al deze landen lieten een daling zien. De export naar Duitsland nam vooral af bij varkens. Naar de Verenigde Staten nam de exportwaarde van (raszuivere fok)paarden af. De exportwaarde naar Spanje steeg fors (+84\%), waardoor het aandeel van Spanje toeneemt tot circa $6 \%$ van het totaal. Van het totaal aan geëxporteerde levende dieren was $83 \%$ van Nederlandse makelij.

In 2018 bedroeg de import van levende dieren 1,2 miljard euro. Dat is ruim 2\% lager dan in 2017. De belangrijkste herkomstlanden in de import zijn Duitsland (54\%) en België (25\%). De daling van de importwaarde uit België komt met name door een waardedaling bij varkens.

Tabel 2.15 Nederlandse handel in levende dieren (GN-01).

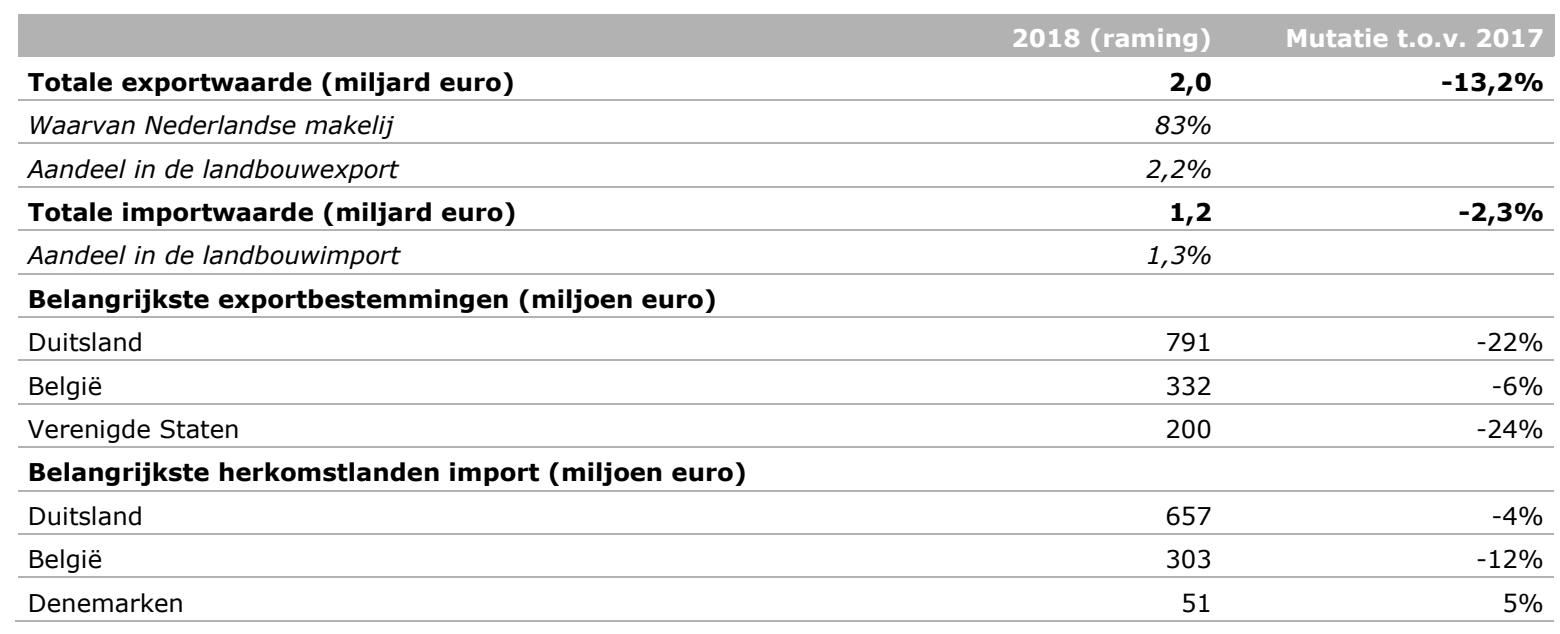

Bron: CBS tot en met oktober 2018, raming november - december 2018 door WUR en CBS.

\subsubsection{Minder export en import van bereidingen van vlees en vis}

De exportwaarde van bereidingsproducten van vlees en vis bedroeg in 20181,7 miljard euro. Dat is een afname van bijna 1\% ten opzichte van 2017 (tabel 2.16). Duitsland en België waren ook in 2018 de belangrijkste exportbestemming, met $29 \%$ en $22 \%$ van de export. De export naar België laat in tegenstelling tot het algemene beeld een sterke stijging zien $(+18 \%)$. Dit betreft met name een waardestijging bij gekookt, bereid of bewaard kippenvlees. Van de totale waarde aan geëxporteerde bereidingen van vlees en vis was in 2018 voor circa 66\% van Nederlandse makelij.

Nederland importeerde in 2018 voor 1,5 miljard euro aan bereidingsproducten van vlees en vis. Dat is $5 \%$ lager dan in 2017. België (20\%) en Duitsland (17\%) nemen het grootste deel van de import voor hun rekening. Grote stijger bij de import is Marokko (+74\%), met een importaandeel van $10 \%$. De waarde toename uit Marokko betreft vooral garnalenproducten. 
Tabel 2.16 Nederlandse handel in bereidingen van vlees en vis (GN-16).

\begin{tabular}{|c|c|c|}
\hline & 2018 (raming) & Mutatie t.o.v. 2017 \\
\hline Totale exportwaarde (miljard euro) & 1,7 & $-0,8 \%$ \\
\hline Waarvan Nederlandse makelij & $66 \%$ & \\
\hline Totale importwaarde (miljard euro) & 1,5 & $-5,0 \%$ \\
\hline Aandeel in de landbouwimport & $1,7 \%$ & \\
\hline Duitsland & 481 & $-4 \%$ \\
\hline België & 366 & $18 \%$ \\
\hline Frankrijk & 173 & $-6 \%$ \\
\hline \multicolumn{3}{|c|}{ Belangrijkste herkomstlanden import (miljoen euro) } \\
\hline
\end{tabular}

Bron: CBS tot en met oktober 2018, raming november - december 2018 door WUR en CBS.

\subsubsection{Meer export en import van suiker en suikerwerk}

Nederland exporteerde in 2018 voor 1,6 miljard euro aan suiker en suikerwerk. Dit is bijna $3 \%$ meer dan in 2017 (tabel 2.17). De belangrijkste exportbestemmingen zijn Duitsland (19\%) en België $(14 \%)$, gevolgd door Frankrijk (10\%) en het Verenigd Koninkrijk (9\%). De exportwaarde naar het Verenigd Koninkrijk nam vergeleken met de andere landen met $12 \%$ af. De export van suiker en suikerwerk in 2018 bestond voor 78\% uit goederen van Nederlandse makelij. Voor de export naar Duitsland lag dit aandeel op 69\%.

De import in 2018 bedroeg 0,9 miljard euro en was bijna 1\% groter dan in 2017. Van de import komt $26 \%$ uit Duitsland, 26\% uit België en 12\% uit Frankrijk. In tegenstelling tot de exportwaarde nam de importwaarde van suiker en suikerwerk uit het Verenigd Koninkrijk in 2018 met 17\% toe. Uit Frankrijk nam vooral de importwaarde van witte suiker toe.

Tabel 2.17 Nederlandse handel in suiker en suikerwerk (GN-17).

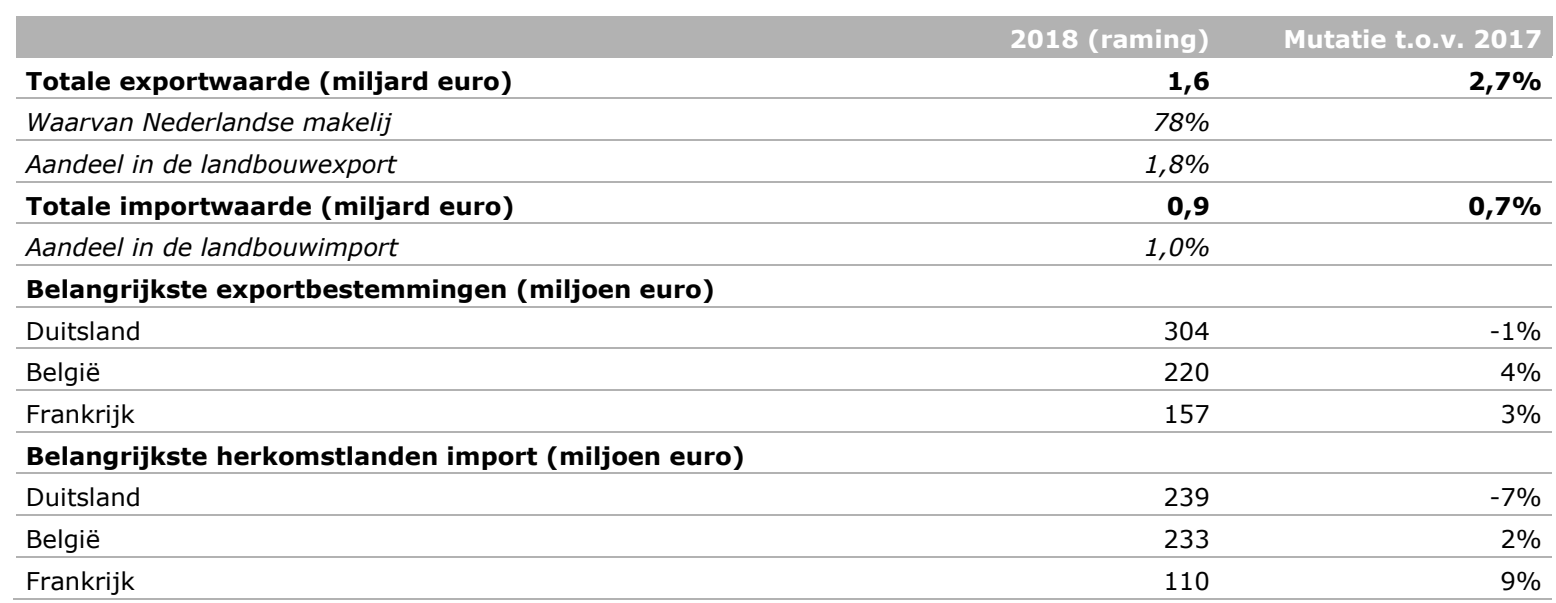

Bron: CBS tot en met oktober 2018, raming november - december 2018 door WUR en CBS.

\subsubsection{Minder export en import van tabak en tabaksproducten}

In 2018 nam de exportwaarde van tabak en tabaksproducten met ruim 30\% af ten opzichte van 2017 en kwam deze uit op 1,2 miljard euro (tabel 2.18). Van deze producten ging $23 \%$ naar Duitsland, $9 \%$ naar het Verenigd Koninkrijk en 9\% naar België. Een zeer sterke daler is Frankrijk, waarnaar de exportwaarde met $75 \%$ afnam (exportaandeel 6\%). Van de geëxporteerde waarde aan tabak en tabaksproducten is $66 \%$ van Nederlandse makelij. De exportdaling naar Duitsland betreft vooral sigaretten en 'gestripte' 
tabak. In 2018 bedroeg de import 0,9 miljard euro, een daling van 17\% ten opzichte van 2017. Het belangrijkste herkomstland bij de import is Polen (27\%), waaruit de import met $5 \%$ toenam. De import uit België (19\%) en Duitsland (12\%) nam met name uit Duitsland sterk af (-37\%; met name sigaretten).

Tabel 2.18 Nederlandse handel in tabak en tabaksproducten (GN-24).

\begin{tabular}{|c|c|c|}
\hline & 2018 (raming) & Mutatie t.o.v. 2017 \\
\hline Waarvan Nederlandse makelij & $66 \%$ & \\
\hline Aandeel in de landbouwexport & $1,3 \%$ & \\
\hline Totale importwaarde (miljard euro) & 0,9 & $-16,9 \%$ \\
\hline Aandeel in de landbouwimport & $1,0 \%$ & \\
\hline Duitsland & 281 & $-35 \%$ \\
\hline Verenigd Koninkrijk & 114 & $-16 \%$ \\
\hline België & 108 & $-32 \%$ \\
\hline \multicolumn{3}{|c|}{ Belangrijkste herkomstlanden import (miljoen euro) } \\
\hline
\end{tabular}

Bron: CBS tot en met oktober 2018, raming november - december 2018 door WUR en CBS.

\subsubsection{Meer export en import van koffie, thee en specerijen}

De exportwaarde van koffie, thee en specerijen nam in 2018 met 2,6\% toe ten opzichte van 2017 en kwam uit op 1,1 miljard euro (tabel 2.19). Frankrijk (22\%), Duitsland (16\%), België (11\%) en het Verenigd Koninkrijk (8\%) zijn de belangrijkste exportbestemmingen. De export naar Duitsland en België nam in 2018 met $11 \%$ en $10 \%$ af, tegenover een vergelijkbare relatieve toename van de exportwaarde naar Frankrijk en het Verenigd Koninkrijk. In alle gevallen betrof dit een waarde mutatie van geroosterde koffie (exclusief cafeïnevrije koffie). De exportwaarde van koffie, thee en specerijen bestond in 2018 voor $54 \%$ uit goederen van Nederlandse makelij. Een groot deel van de export betreft dus wederuitvoer.

Nederland importeerde in 2018 voor ruim 1,5 miljard euro aan koffie, thee en specerijen. Dat is een stijging van $0,5 \%$ ten opzichte van 2017 . Nederland importeerde voor deze goederengroep dus meer producten dan het exporteerde. België (22\%), Duitsland (21\%) en Frankrijk (13\%) hadden het grootste aandeel van de import. De importwaarde vanuit Frankrijk nam met $12 \%$ toe (met name door geroosterde koffie, exclusief cafeïnevrije), terwijl die uit België en Duitsland met $9 \%$ respectievelijk $11 \%$ daalde.

Tabel 2.19 Nederlandse handel in koffie, thee en specerijen (GN-09).

\begin{tabular}{lrr} 
& 2018 (raming) & Mutatie t.0.v. 2017 \\
\hline Totale exportwaarde (miljard euro) & $\mathbf{1 , 1}$ & $55 \%$ \\
\hline Waarvan Nederlandse makelij & $1,2 \%$ & $\mathbf{2} \%$ \\
\hline Aandeel in de landbouwexport & $1,7 \%$ & $\mathbf{0 , 5} \%$ \\
\hline Totale importwaarde (miljard euro) & 244 \\
\hline Aandeel in de landbouwimport & 178 \\
\hline Belangrijkste exportbestemmingen (miljoen euro) & 124 \\
\hline Frankrijk & $10 \%$ \\
\hline Duitsland & $-8 \%$ \\
\hline België & $-11 \%$ \\
\hline Belangrijkste herkomstlanden import (miljoen euro) & 335 \\
\hline België & 313 \\
\hline Duitsland & 194 \\
\hline Frankrijk & $-9 \%$ \\
\hline
\end{tabular}

Bron: CBS tot en met oktober 2018, raming november - december 2018 door WUR en CBS. 


\subsubsection{Meer export van meel, mout en zetmeel, vergelijkbaar niveau bij import}

In 2018 bedroeg de exportwaarde van meel, mout en zetmeelproducten 0,7 miljard euro. Dat is een toename van ruim 10\% ten opzichte van 2017 (tabel 2.20). Van deze goederen ging 15\% naar Duitsland en $13 \%$ naar België. De export naar Duitsland nam toe (12\%; van mout en aardappelmeel), terwijl die naar België met $1 \%$ daalde. Een andere belangrijke stijger is Frankrijk (+29\%), met een exportaandeel van $6 \%$. De exportwaarde van meelindustrieproducten is voor circa $89 \%$ van Nederlandse makelij.

De import van meel, mout en zetmeel bedroeg in 2018 bijna 0,8 miljard euro en is vergelijkbaar met 2017. Het grootste deel van de import komt uit Duitsland (38\%), België (36\%) en Frankrijk (12\%).

Tabel 2.20 Nederlandse handel in meel, mout en zetmeel (GN-11).

\begin{tabular}{|c|c|c|}
\hline & 2018 (raming) & Mutatie t.o.v. 2017 \\
\hline Totale exportwaarde (miljard euro) & 0,7 & $10,5 \%$ \\
\hline Waarvan Nederlandse makelij & $89 \%$ & \\
\hline Totale importwaarde (miljard euro) & 0,8 & $-0,3 \%$ \\
\hline Aandeel in de landbouwimport & $0,9 \%$ & \\
\hline Duitsland & 108 & $12 \%$ \\
\hline België & 99 & $-1 \%$ \\
\hline Verenigd Koninkrijk & 55 & $2 \%$ \\
\hline \multicolumn{3}{|c|}{ Belangrijkste herkomstlanden import (miljoen euro) } \\
\hline
\end{tabular}

Bron: CBS tot en met oktober 2018, raming november - december 2018 door WUR en CBS.

\subsubsection{Meer export en import van overige producten van dierlijke oorsprong}

Nederland exporteerde in 2018 voor ruim 0,6 miljard euro aan overige producten van dierlijke oorsprong. Dat is een toename van ruim 17\% ten opzichte van 2017 (tabel 2.21). Het gaat hier om een diverse groep producten, zoals rundersperma, darmen, blazen, magen, veren, haren en visafval. Van deze producten ging 21\% naar Duitsland, 15\% naar China en 10\% naar Frankrijk. Slechts 37\% van de waarde aan geëxporteerde goederen is van Nederlandse makelij. Veel van de export bestaat dus uit wederuitvoer. De exporttoename naar Duitsland, Frankrijk en China betreft vooral waardestijgingen bij darmen, blazen en magen.

In 2018 bedroeg de import van andere producten van dierlijke oorsprong 0,4 miljard euro, een toename van $3 \%$ ten opzichte van 2017. China is het belangrijkste herkomstland van de import (36\%), gevolgd door Duitsland (25\%), het Verenigd Koninkrijk (12\%) en België (7\%). De toegenomen importwaarde uit het Verenigd Koninkrijk betreft ook darmen, blazen en magen. 
Tabel 2.21 Nederlandse handel in overige producten van dierlijke oorsprong (GN-05).

\begin{tabular}{|c|c|c|}
\hline & 2018 (raming) & Mutatie t.o.v. 2017 \\
\hline Totale exportwaarde (miljard euro) & 0,6 & $17,3 \%$ \\
\hline Waarvan Nederlandse makelij & $37 \%$ & \\
\hline Totale importwaarde (miljard euro) & 0,4 & $3,3 \%$ \\
\hline Aandeel in de landbouwimport & $0,5 \%$ & \\
\hline Duitsland & 129 & $24 \%$ \\
\hline China & 94 & $19 \%$ \\
\hline Frankrijk & 60 & $22 \%$ \\
\hline \multicolumn{3}{|c|}{ Belangrijkste herkomstlanden import (miljoen euro) } \\
\hline
\end{tabular}

Bron: CBS tot en met oktober 2018, raming november - december 2018 door WUR en CBS.

\subsubsection{Meer export en import van granen}

De exportwaarde van granen bedroeg in 2018 bijna 0,5 miljard euro. Dat is een toename van ruim $10 \%$ ten opzichte van 2017 (tabel 2.22). Duitsland (37\%) en België (22\%) zijn de belangrijkste exportbestemmingen. Daarna volgen het Verenigd Koninkrijk (11\%) en Frankrijk (9\%). Opvallend is de sterke daling van de exportwaarde naar België (-34\%; met name door maïs). De exporttoename naar Duitsland komt eveneens door maïs. In 2018 bestond de export van graan voor $42 \%$ uit Nederlandse makelij.

Tabel 2.22 Nederlandse handel in granen (GN-10).

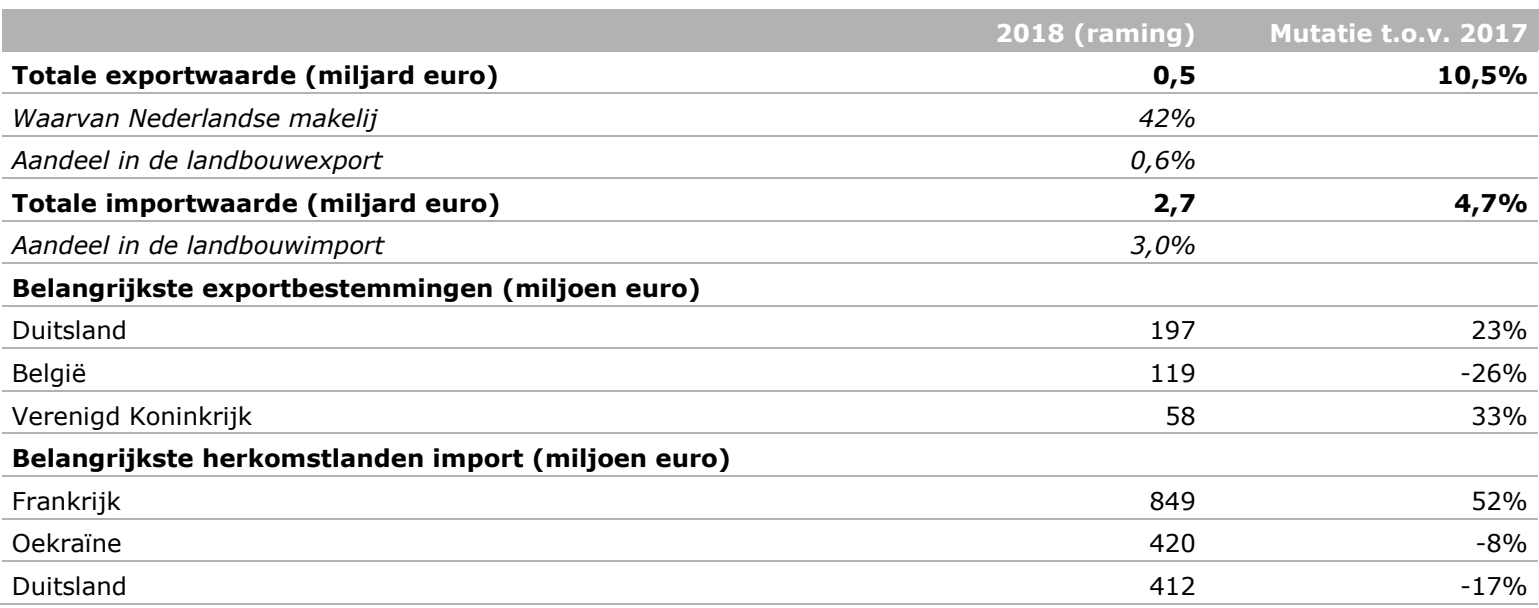

Bron: CBS tot en met oktober 2018, raming november - december 2018 door WUR en CBS.

Nederland importeerde in 2018 voor 2,7 miljard euro aan graan. Dat is bijna 5\% meer dan in 2017. Het handelsbalanstekort voor graan is groot. Een deel van de graanimport is bestemd voor dierlijke consumptie. Van de graanimport komt 31\% uit Frankrijk, 16\% uit Oekraïne, 15\% uit Duitsland en 10\% uit België. In 2018 nam de import uit Frankrijk aanzienlijk toe voor de producten tarwe en mengkoren, terwijl dit uit Duitsland juist afnam.

\subsubsection{Meer export en import van plantensappen}

In 2018 bedroeg de exportwaarde van plantensappen 0,1 miljard euro. Dat is een forse toename, van $64 \%$, ten opzichte van 2017 (tabel 2.23). Met name de exportwaarde naar de Verenigde Staten nam explosief toe ( $+184 \%$; van groentesappen en extracten). De Verenigde Staten hebben daarmee een exportaandeel van 35\%. De exportwaarde naar België steeg eveneens explosief (+206\%; van 
slijmstoffen en verdikkingsmiddelen). Na de Verenigde Staten zijn Duitsland (13\%) en België ( $8 \%)$ de belangrijkste exportbestemmingen. Van de totale waarde aan geëxporteerde plantensappen is $81 \%$ van Nederlandse makelij.

De importwaarde van plantensappen bedroeg in 2018 bijna 0,2 miljard euro en nam met ruim 23\% toe ten opzichte van 2017. De belangrijkste herkomstlanden in de import zijn Duitsland (17\%), de Verenigde Staten (17\%), België (14\%) en Frankrijk (11\%). Net als de export nam ook de import uit de Verenigde Staten explosief toe (+172\%; van groentesappen en extracten).

Tabel 2.23 Nederlandse handel in plantensappen (GN-13).

\begin{tabular}{|c|c|c|}
\hline & 2018 (raming) & Mutatie t.o.v. 2017 \\
\hline Waarvan Nederlandse makelij & $78 \%$ & \\
\hline Totale importwaarde (miljard euro) & 0,2 & $23,5 \%$ \\
\hline Aandeel in de landbouwimport & $0,2 \%$ & \\
\hline Verenigde Staten & 49 & $184 \%$ \\
\hline Duitsland & 18 & $37 \%$ \\
\hline België & 11 & $206 \%$ \\
\hline \multicolumn{3}{|c|}{ Belangrijkste herkomstlanden import (miljoen euro) } \\
\hline
\end{tabular}

Bron: CBS tot en met oktober 2018, raming november - december 2018 door WUR en CBS.

\subsubsection{Meer export en import van vlechtstoffen}

De exportwaarde van vlechtstoffen (bijvoorbeeld bamboe en riet) bedroeg in 2018 bijna 39 miljoen euro. Dat is een toename van bijna $10 \%$ ten opzichte van 2017 . Het aandeel in de totale landbouwexport is beperkt (tabel 2.24). De belangrijkste exportbestemmingen zijn Duitsland (33\%), België (22\%) en het Verenigd Koninkrijk (17\%). De export naar Duitsland is fors toegenomen (+76\%; van groentegerelateerde producten). In 2018 bestond de exportwaarde van vlechtstoffen voor $43 \%$ uit producten van Nederlandse makelij.

Nederland importeerde voor bijna 76 miljoen euro aan vlechtstoffen. De twee belangrijkste herkomstlanden van de import zijn China (34\%) en India (29\%). De importtoename uit India betrof met name een stijging van de waarde aan groentegerelateerde producten.

Tabel 2.24 Nederlandse handel in vlechtstoffen (GN-14).

\begin{tabular}{|c|c|c|}
\hline & 2018 (raming) & Mutatie t.0.v. 2017 \\
\hline Waarvan Nederlandse makelij & $42 \%$ & \\
\hline Totale importwaarde (miljoen euro) & 76 & $15,5 \%$ \\
\hline Aandeel in de landbouwimport & $0,1 \%$ & \\
\hline Duitsland & 12 & $54 \%$ \\
\hline België & 8 & $-6 \%$ \\
\hline Verenigd Koninkrijk & 7 & $-10 \%$ \\
\hline \multicolumn{3}{|c|}{ Belangrijkste herkomstlanden import (miljoen euro) } \\
\hline
\end{tabular}

Bron: CBS tot en met oktober 2018, raming november - december 2018 door WUR en CBS. 
2.3.25 Minder export van overige primaire en secundaire landbouwgoederen, groei bij import

De exportwaarde van overige primaire en secundaire landbouwproducten bedroeg in 2018 3,6 miljard euro (tabel 2.25). Dat is een daling van $1 \%$ vergeleken met 2017. Duitsland heeft het grootste aandeel in de export (22\%), gevolgd door België (11\%). Samen met het Verenigd Koninkrijk (8\%), Frankrijk (7\%) en Italië (7\%) bedroeg dit ruim de helft van de exportwaarde. De exportwaarde van deze overige primaire en secundaire landbouwgoederen bestaat voor $74 \%$ uit goederen van Nederlandse makelij. De import van deze groep landbouwproducten bedroeg 3,9 miljard euro en nam met ruim 3\% toe ten opzichte van 2017. De import kwam in 2018 met name uit Duitsland (21\%), Indonesië $(11 \%)$ en België (11\%), waarbij de import uit Duitsland met 13\% steeg.

Tabel 2.25 Nederlandse handel in overige primaire en secundaire landbouwgoederen.

\begin{tabular}{lrr} 
& 2018 (raming) & Mutatie t.0.v. 201.7 \\
\hline Totale exportwaarde (miljard euro) & $\mathbf{3 , 6}$ & $\mathbf{- 1 , 0 \%}$ \\
\hline Waarvan Nederlandse makelij & $\mathbf{7 4 \%}$ & $\mathbf{4} \%$ \\
\hline Aandeel in de landbouwexport & $\mathbf{3 , 9}$ & $\mathbf{9}, 3 \%$ \\
\hline Totale importwaarde (miljard euro) & $\mathbf{3 , 5 \%}$ \\
\hline Aandeel in de landbouwimport & 788 & 381 \\
\hline Belangrijkste exportbestemmingen (miljoen euro) & 286 \\
\hline Duitsland & $-1 \%$ \\
\hline België & $-1 \%$ \\
\hline Verenigd Koninkrijk & $-3 \%$ \\
\hline Belangrijkste herkomstlanden import (miljoen euro) & 798 \\
\hline Duitsland & 429 \\
\hline België & 423 \\
\hline Indonesië & $13 \%$ \\
\hline
\end{tabular}

Bron: CBS tot en met oktober 2018, raming november - december 2018 door WUR en CBS.

\subsection{Handel in landbouwgoederen met Duitsland gedaald}

Duitsland is al jaren veruit de belangrijkste handelspartner voor Nederland, voor zowel de export- als de importwaarde van landbouwgoederen, met respectievelijke aandelen in 2018 van $25,3 \%$ en $18,5 \%$ van de totale agrarische handel. Zowel de export naar als de import uit Duitsland nam in 2018 af, respectievelijk met 1,6 en 0,4\% ten opzichte van 2017. De waarde van de landbouwexport en -import naar en uit Duitsland bedroeg in 2018 respectievelijk 22,7 en 11,4 miljard euro.

\subsubsection{Nederlandse invoer uit Duitsland licht gedaald}

Nederland heeft in 2018 volgens de eerste raming voor 61,4 miljard euro aan landbouwgoederen ingevoerd. Hiervan kwam 11,4 miljard euro uit Duitsland (figuur 2.9). Duitsland is de belangrijkste leverancier van landbouwgoederen die in Nederland worden geïmporteerd. Op enige afstand volgen België (8,6 miljard euro) en Frankrijk (4,0 miljard euro).

Van de totale importwaarde van goederen uit Duitsland heeft ruim 14\% betrekking op landbouwgoederen. Ongeveer $20 \%$ van de landbouwgoederen die Nederland importeert, komt uit Duitsland. 


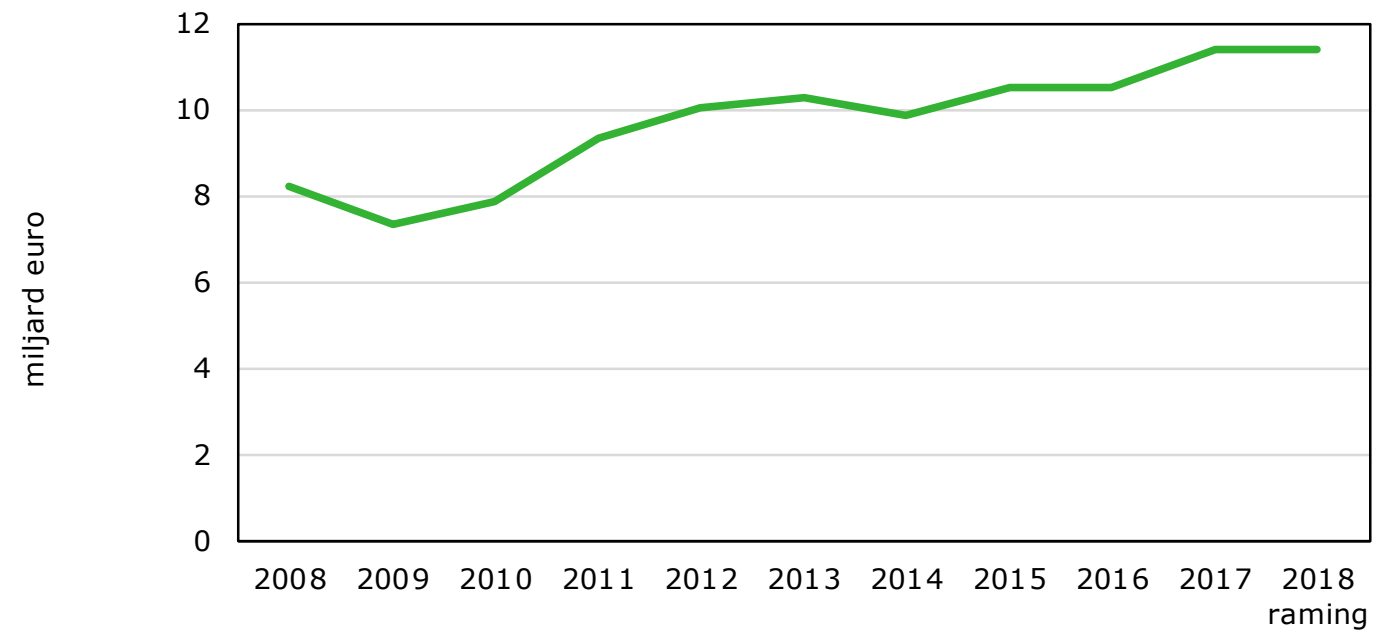

Figuur 2.9 Nederlandse importwaarde van landbouwgoederen uit Duitsland.

Bron: CBS tot en met oktober 2018, raming november - december 2018 door WUR en CBS.

De belangrijkste landbouwgoederen die uit Duitsland werden geïmporteerd, zijn zuivel en eieren (1,6 miljard euro). Daarna volgen op enige afstand vlees, de restgroep van overige primaire en secundaire landbouwgoederen, natuurlijke vetten en oliën, dranken, levende dieren en resten uit de voedselindustrie en veevoer (figuur 2.10). De importwaarde van zuivel en eieren en de restgroep van overige primaire en secundaire landbouwgoederen nam in 2018 (licht) toe, terwijl dit van de andere vermelde landbouwgoederen afnam. De totale importwaarde van landbouwgoederen nam in 2018 met 38 miljoen euro af ten opzichte van 2017. Dat is een afname van 0,3\% (figuur 2.11). De drie grootste stijgers bij de import uit Duitsland in 2018 waren overige primaire en secundaire landbouwgoederen, overige voeding en bereidingen van graan, zetmeel en melk. De grootste dalers in importwaarde betroffen de categorieën vlees, granen, tabak en tabaksproducten en natuurlijke vetten en oliën. De afgenomen waarde van de vleesimport uit Duitsland hing vooral samen met een importdaling van verse of gekoelde vleessoorten. 
Zuivel en eieren

Vlees

Overige primaire en secundaire landbouw

Natuurlijke vetten en oliën

Dranken

Levende dieren

Resten voedselindustrie, veevoer

Overige voeding

Bereidingen van graan, meel, melk

Bereidingen van groente en fruit

Graan

Groenten

Fruit

Sierteelt

Cacao en cacaobereidingen

Vis en zeevruchten Koffie, thee, specerijen

Meel, mout, zetmeel

Bereidingen van vlees en vis

Suiker en suikerwerk

Oliehoudende zaden en vruchten

Tabak en tabaksproducten

Andere producten van dierlijke oorsprong

Plantensappen

Vlechtstoffen

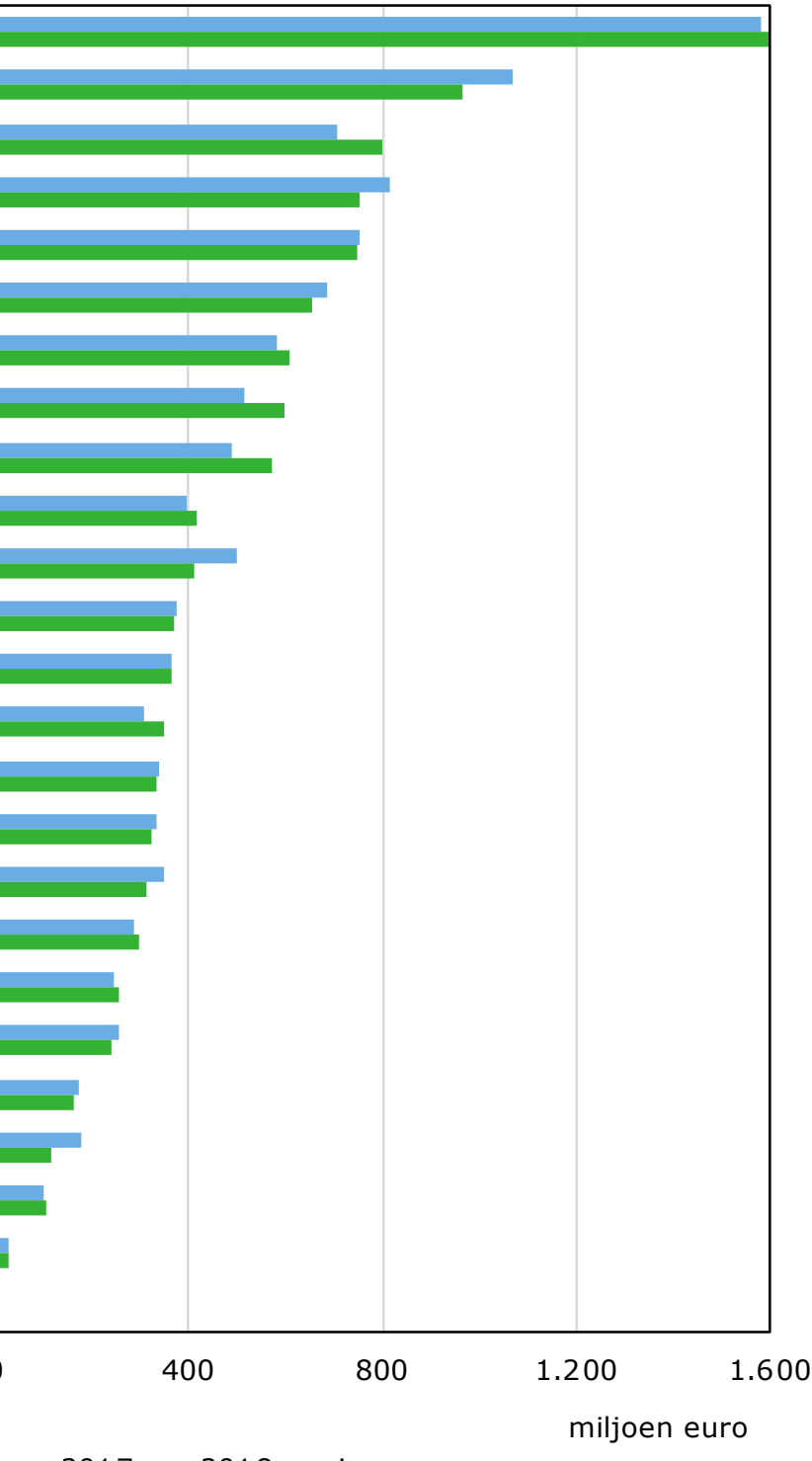

$2017 \quad 2018$ raming

Figuur 2.10 Nederlandse importwaarde van landbouwgoederen uit Duitsland per goederenhoofdstuk. Bron: CBS tot en met oktober 2018, raming november - december 2018 door WUR en CBS. 
Landbouwgoederen (totaal)

Overige primaire en secundaire landbouw

Overige voeding

Bereidingen van graan, meel, melk

Sierteelt

Resten voedselindustrie, veevoer

Bereidingen van groente en fruit

Zuivel en eieren

Meel, mout, zetmeel

Bereidingen van vlees en vis

Andere producten van dierlijke oorsprong

Fruit

Vlechtstoffen

Plantensappen

Dranken

Groenten

Cacao en cacaobereidingen

Vis en zeevruchten

Oliehoudende zaden en vruchten

Suiker en suikerwerk

Levende dieren

Koffie, thee, specerijen

Natuurlijke vetten en oliën

Tabak en tabaksproducten

Graan

Vlees

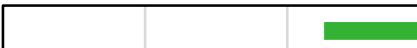

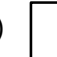




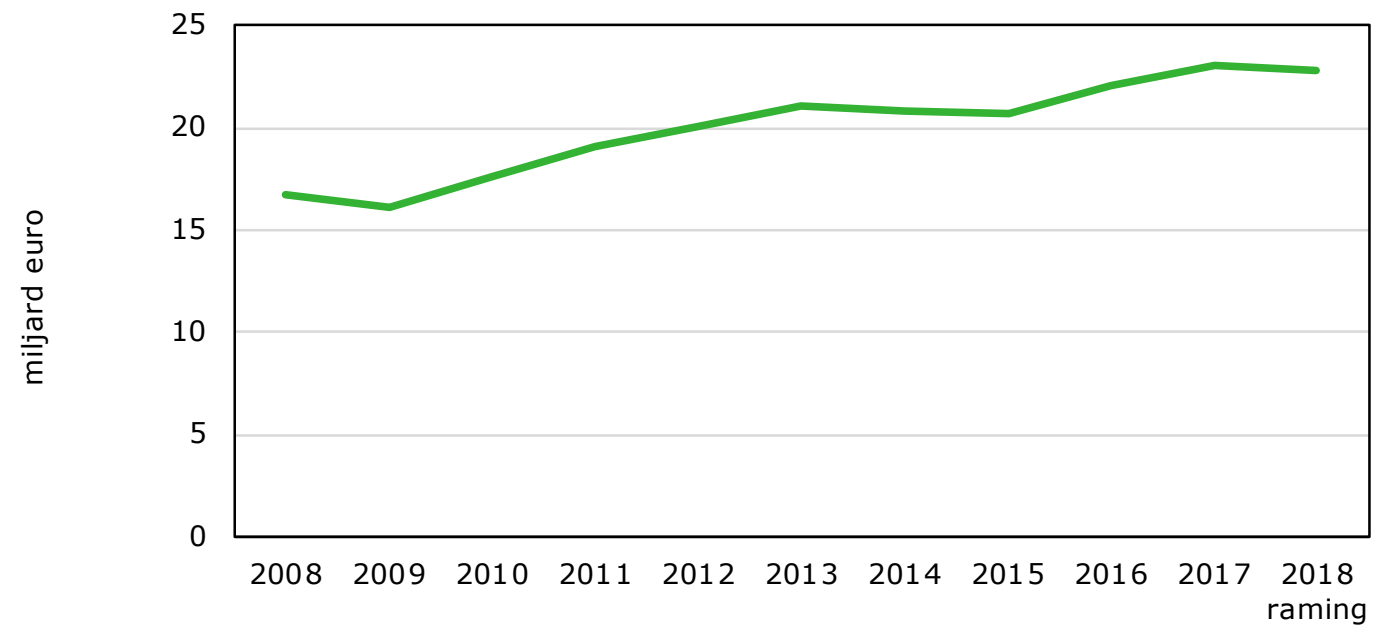

Figuur 2.12 Exportwaarde van Nederlandse landbouwgoederen naar Duitsland. Bron: CBS tot en met oktober 2018, raming november - december 2018 door WUR en CBS.

De belangrijkste vier landbouwgoederengroepen die naar Duitsland worden geëxporteerd, zijn sierteelt, zuivel en eieren, fruit en groenten, met elk een exportwaarde van meer dan 2 miljard euro (figuur 2.13). Van deze vier nam de exportwaarde van sierteelt en fruit in 2018 substantieel toe. De exportwaarde van fruit naar Duitsland steeg met 14\% ten opzichte van 2017. De exportwaarde van fruit naar Duitsland nam met name toe door verse appels (zie paragraaf 3.1) en tafeldruiven. Bij sierteeltproducten hing de toename van de exportwaarde naar Duitsland vooral samen met de toegenomen exportwaarde van overige snijbloemen, bestemd voor onder andere boeketten (zie paragraaf 3.4).

De totale exportwaarde van landbouwgoederen naar Duitsland nam in 2018 met 310 miljoen euro af. Deze daling werd hoofdzakelijk veroorzaakt door een afname van de export van levende dieren, oliehoudende zaden en vruchten, tabak en tabaksproducten, natuurlijke vetten en oliën en cacao en cacaobereidingen. De lagere exportwaarde bij levende dieren werd met name veroorzaakt door lagere prijzen van vleesvarkens en biggen bij de varkens. Voor de meeste categorieën landbouwgoederen was de mutatie in importwaarde tussen 2017 en 2018 beperkt (figuur 2.14). 


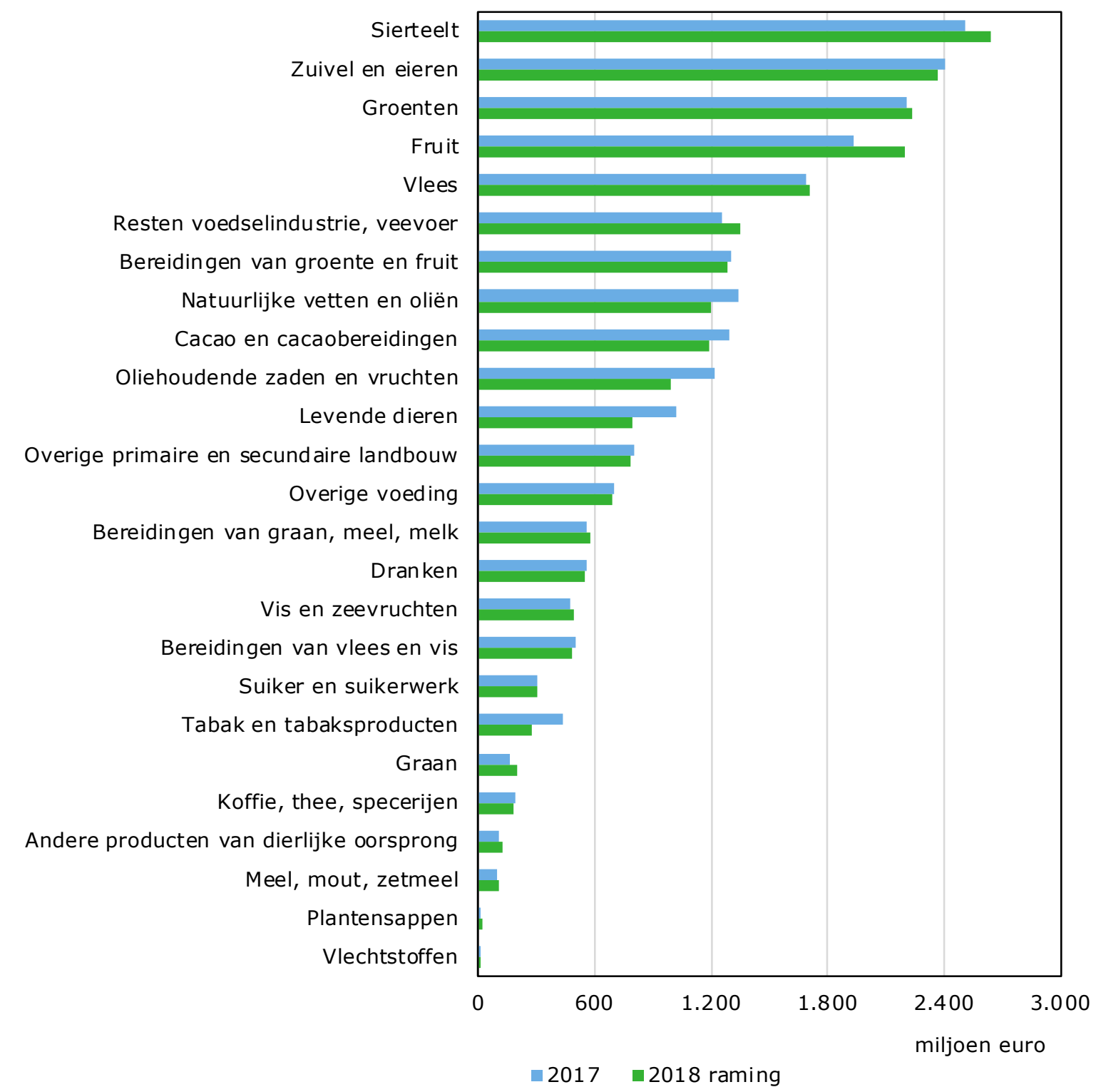

Figuur 2.13 Exportwaarde van Nederlandse landbouwgoederen naar Duitsland per goederenhoofdstuk.

Bron: CBS tot en met oktober 2018, raming november - december 2018 door WUR en CBS. 
Landbouwgoederen (totaal)

Fruit

Sierteelt

Resten voedselindustrie, veevoer

Graan

Groenten

Andere producten van dierlijke oorsprong

Vlees

Bereidingen van graan, meel, melk

Vis en zeevruchten

Meel, mout, zetmeel

Plantensappen

Vlechtstoffen

Suiker en suikerwerk

Overige voeding

Overige primaire en secundaire landbouw

Dranken

Koffie, thee, specerijen

Bereidingen van vlees en vis

Bereidingen van groente en fruit

Zuivel en eieren

Cacao en cacaobereidingen

Natuurlijke vetten en oliën

Tabak en tabaksproducten

Oliehoudende zaden en vruchten

Levende dieren

$-400$
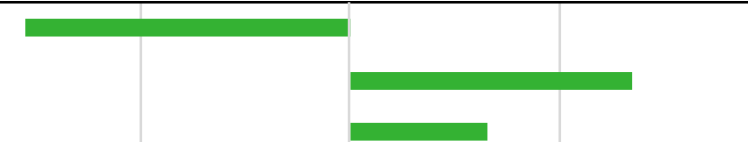

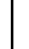

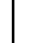




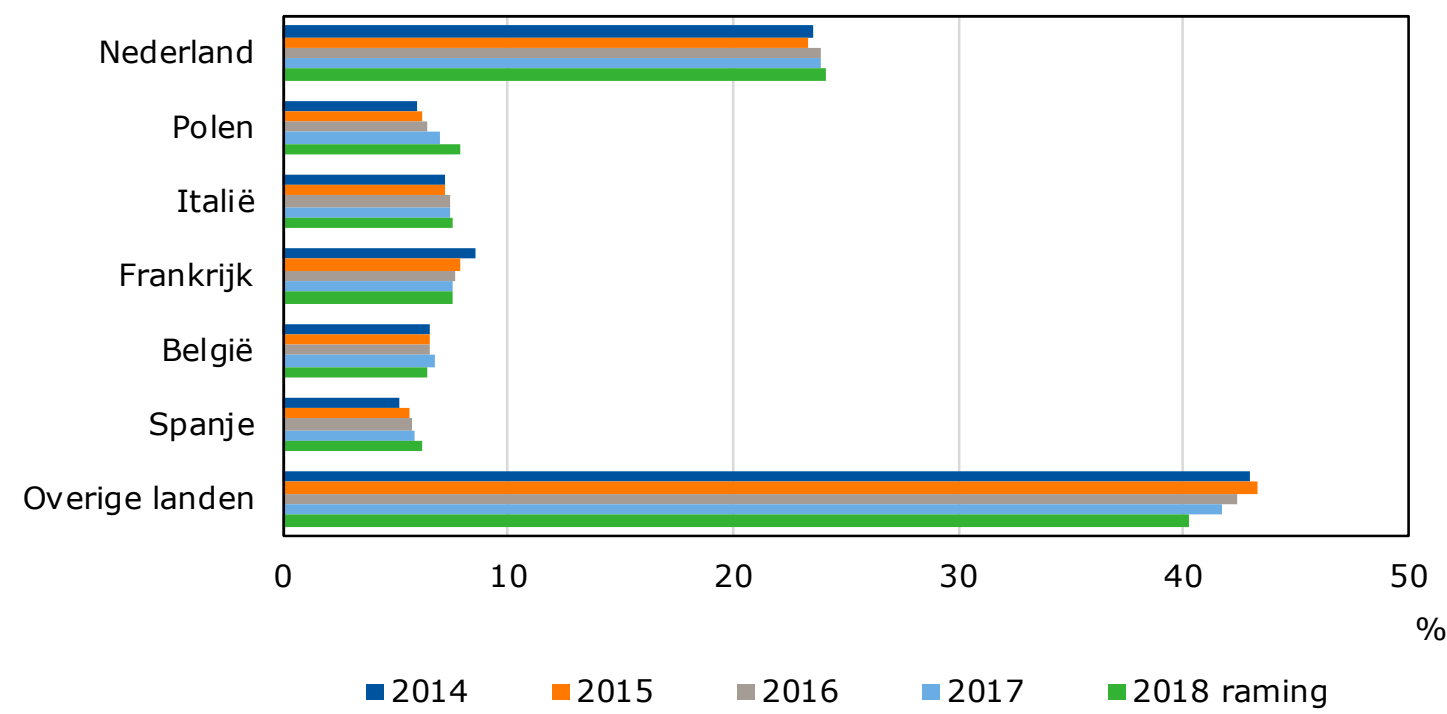

Figuur 2.15 Aandeel van de belangrijkste herkomstlanden in de Duitse import van landbouwgoederen.

Bron: Comext/Eurostat tot en met september 2018, raming oktober - december 2018 door WUR en CBS.

\subsubsection{Export naar zuidelijke deelstaten van Duitsland neemt af na jaren van stijging}

De importwaarde van alle deelstaten van Duitsland is weergegeven in figuur 2.16. Na NoordrijnWestfalen (38\%) en Nedersaksen (12\%) waren de zuidelijke deelstaten Baden-Württemberg (ruim $12 \%$ ) en Beieren (bijna $9 \%$ ) de belangrijkste deelstaten als het gaat om import van Nederlandse herkomst. De totale importwaarde van Nederlandse agrarische producten naar de twee zuidelijke Duitse deelstaten Beieren en Baden-Württemberg gezamenlijk daalde in 2018 naar bijna 3,3 miljard euro. Dit is een daling van $1,5 \%$ ten opzichte van 2017 . Veel van de agrarische producten werden in deze zuidelijke deelstaten betrokken uit de daar omringende landen. Van de belangrijkste vijf productgroepen die uit Nederland in deze zuidelijke deelstaten werden ingevoerd, was alleen bij groenteproducten en planten een waardestijging te zien.

Binnen de totale import van agrarische producten uit Nederland in de twee zuidelijke deelstaten was de import van verse groenten, planten en kaas het grootst, met een aandeel van 15, 14 en $12 \%$ (figuur 2.17). De importwaarde van verse groenten uit Nederland liet in 2018 een grote stijging zien van $7 \%$ ten opzichte van 2017. Dit hangt mogelijk samen met de lagere productie in (zuidelijke landen van) Europa ten gevolge van de warme zomerperiode. Na de sterke importtoename uit Nederland in 2017 van cacao en cacaobereidingen is de importwaarde van deze producten in de twee zuidelijke deelstaten in 2018 afgenomen. De verklaring ligt waarschijnlijk in de gestegen prijzen van cacao vanaf februari 2018 (Finanzen, 2018), wat de vraag naar cacao en bereidingen heeft verminderd. 


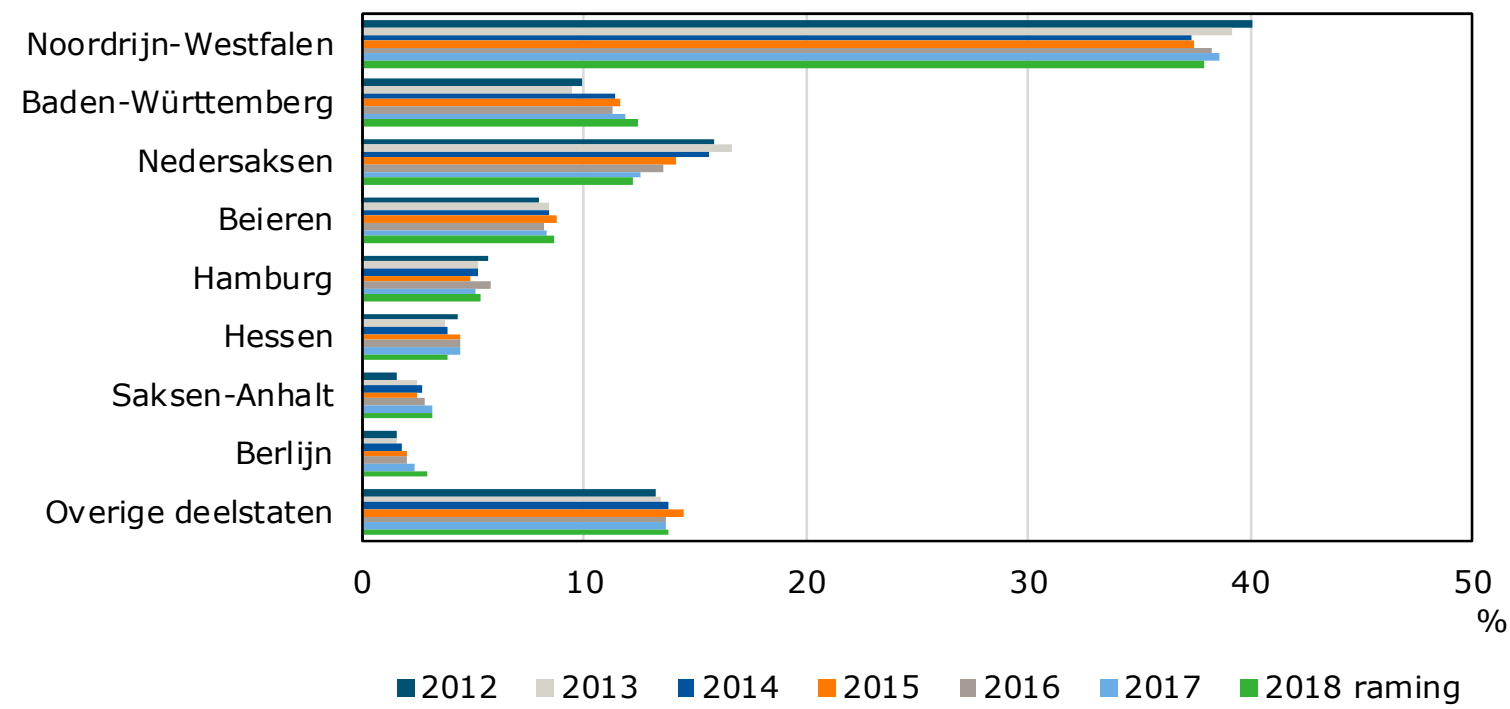

Figuur 2.16 Verdeling van de Duitse import van landbouwgoederen uit Nederland naar deelstaat. Bron: Destatis tot en met september 2018, raming oktober - december 2018 door WUR en CBS.

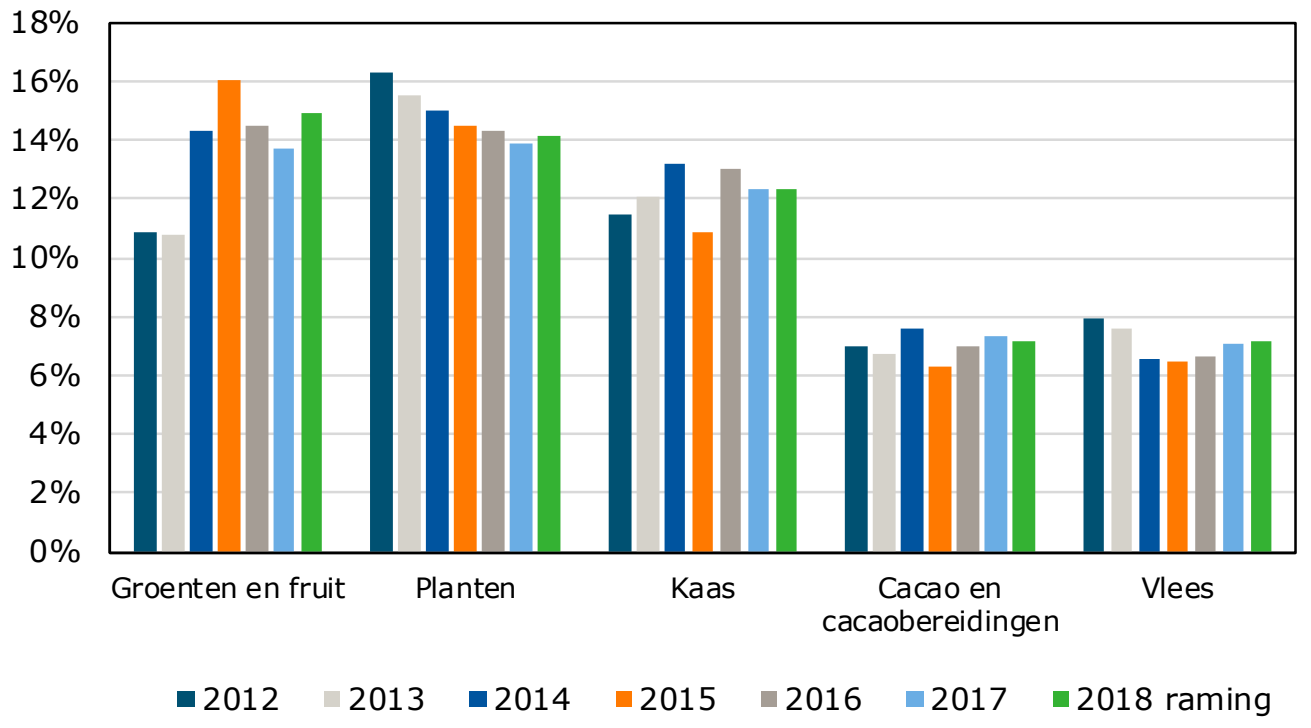

Figuur 2.17 Verdeling van de Zuid-Duitse import van landbouwgoederen uit Nederland naar productgroep.

Bron: Destatis tot en met september 2018, raming oktober - december 2018 door WUR en CBS. 


\section{Specifieke landbouwgoederen uitgelicht}

De in dit hoofdstuk beschreven productgroepen hebben een directe link met belangrijke Nederlandse agrarische sectoren en zijn ook van belang in de handelsrelatie met buurland Duitsland. De in dit hoofdstuk toegelichte producten vertegenwoordigen allemaal een grote Nederlandse primaire sector. Voor bijna al deze beschreven producten is Duitsland exportbestemming nummer één, bevroren aardappels en varkensvlees en bloembollen uitgezonderd. Bij deze eerste twee producten is Duitsland het exportland nummer twee. Maar ook voor de Nederlandse import geldt dat voor deze producten Duitsland veelal in de top twee te vinden is. In de laatste paragraaf wordt ingegaan op de ontwikkeling van landbouwgerelateerde goederen.

\subsection{Waarde appelexport ongeveer gelijk aan import}

De waarde van de export (inclusief re-export) en die van de import van appels houden elkaar vrijwel in evenwicht. Nederland importeerde in 2018 voor 264 miljoen euro aan appels. Iets minder dan de helft hiervan is afkomstig uit andere EU-landen. Iets meer dan de helft betreft appels waarvan de oorsprong buiten Europa ligt, zoals Chili en Nieuw-Zeeland. De export van appels ging voor een groot deel naar Duitsland, namelijk 50\%. Naar landen buiten de EU wordt weinig geëxporteerd. De exportwaarde van in Nederland geteelde appels is ongeveer een derde van de totale exportwaarde.

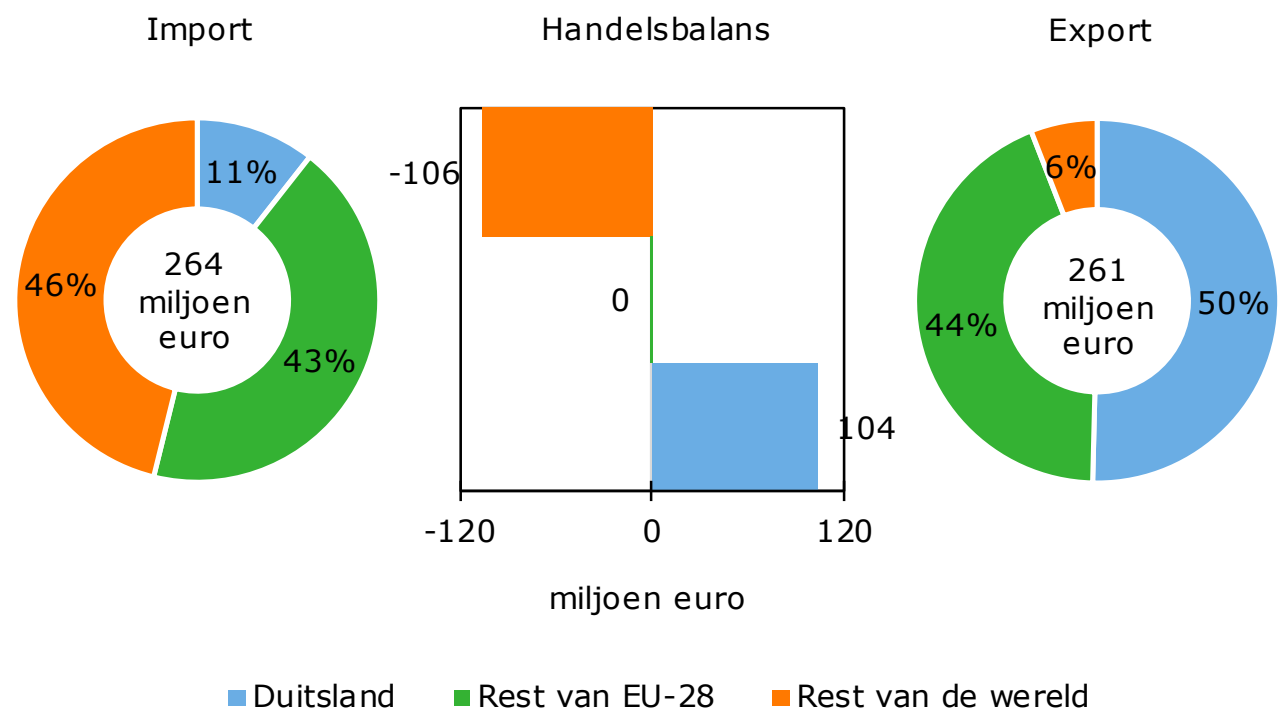

Figuur 3.1 Import en export van appels in 2018 naar regio.

Bron: CBS tot en met oktober 2018, raming november - december 2018 door WUR en CBS.

\subsubsection{Klein aanbod zorgt voor hoge prijs}

In 2018 nam de exportwaarde (inclusief re-export) naar Duitsland toe tot 132 miljoen euro. De exportgroei was vooral te danken aan de lage appeloogst in 2017 in Europa, maar zeker ook in Duitsland. Door de lage Duitse productie ontstond ruimte voor Nederlandse appels. De prijzen voor de appels van oogstjaar 2017 die ook in kalenderjaar 2018 werden afgezet, waren beduidend hoger dan de jaren ervoor. De oogst van 2018 was ondanks de extreem droge zomer ruimer dan het jaar ervoor, waardoor de vraag uit Duitsland afnam en de prijzen daalden. Na Duitsland is België de belangrijkste Europese exportbestemming, maar wel beduidend kleiner ( 41 miljoen euro). De totale exportwaarde 
van 261 miljoen euro was hoog, vooral door de hoge appelprijzen in het eerste deel van 2018. Het jaar 2013 blijft het recordjaar. Destijds was de Europese appelproductie laag als gevolg van vorstschade, waardoor de appels goed werden betaald.

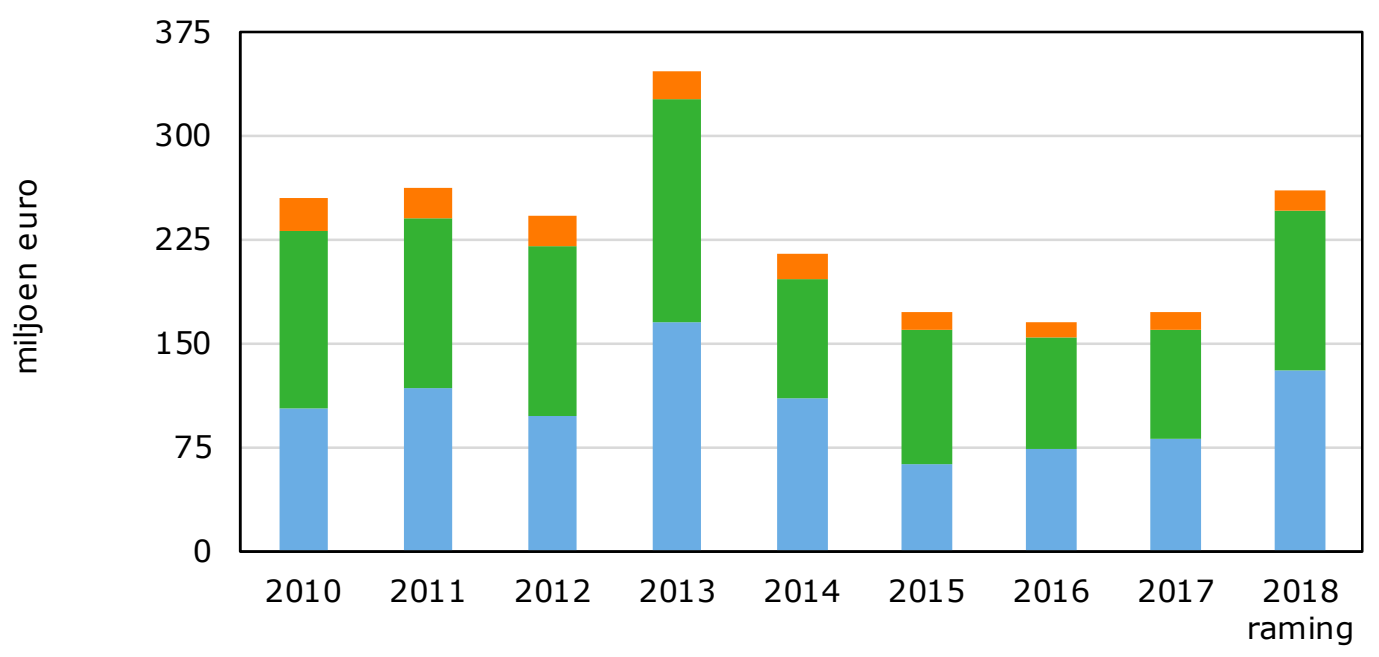

Duitsland $\quad$ Rest van EU-28 $\quad$ Rest van de wereld

Figuur 3.2 Nederlandse export van appels.

Bron: CBS tot en met oktober 2018, raming november - december 2018 door WUR en CBS.

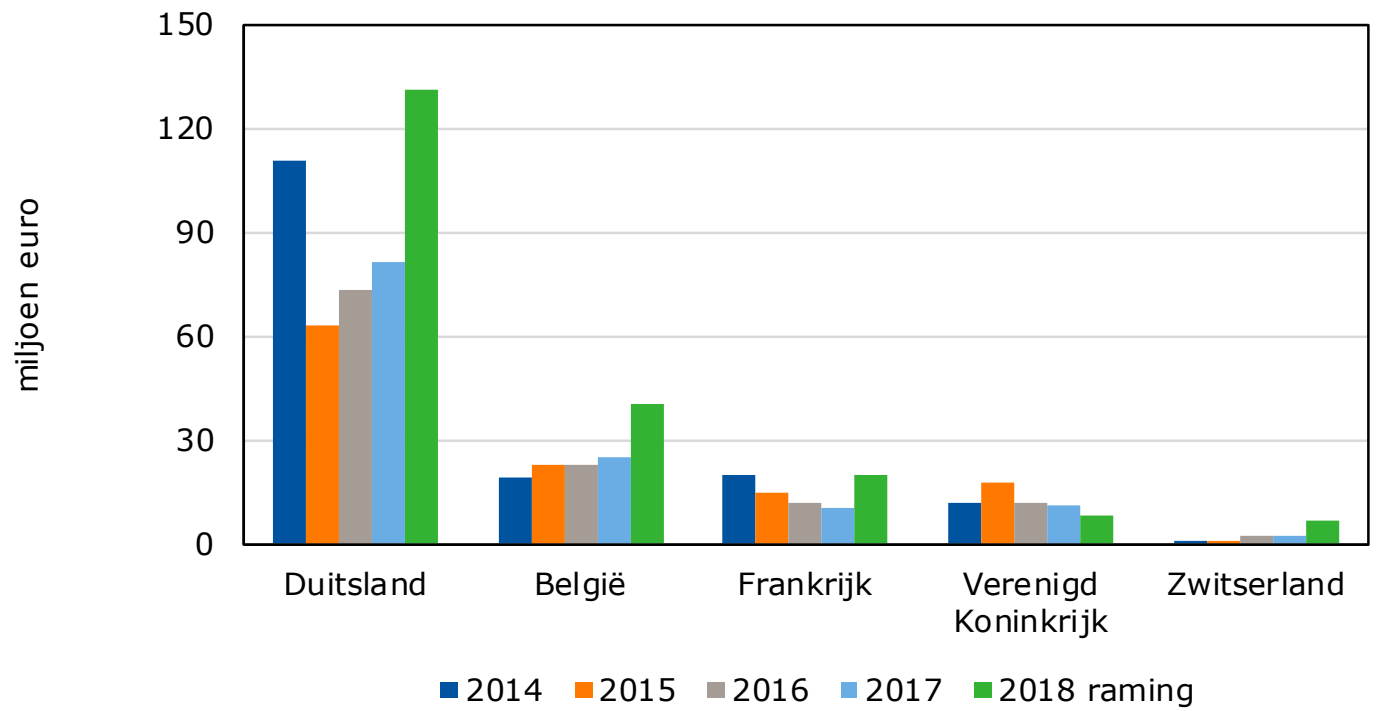

Figuur 3.3 Belangrijkste bestemmingen in de Nederlandse export van appels.

Bron: CBS tot en met oktober 2018, raming november - december 2018 door WUR en CBS.

\subsubsection{Marktaandeel Nederland in Duitse import rond 25\%}

Nederland levert ongeveer $25 \%$ van de totale hoeveelheid appels die Duitsland importeert. Toch is ons land niet de belangrijkste appelleverancier. Ongeveer $40 \%$ van de appels die Duitsland importeert, komt namelijk uit Italië. Italië is Europa's grootste producent van Golden Delicious en Gala, appelsoorten die voor Nederlandse fruittelers van beduidend minder belang zijn. Van de in Nederland geteelde appels gaan vooral Elstar en Jonagold naar onze oosterburen. 


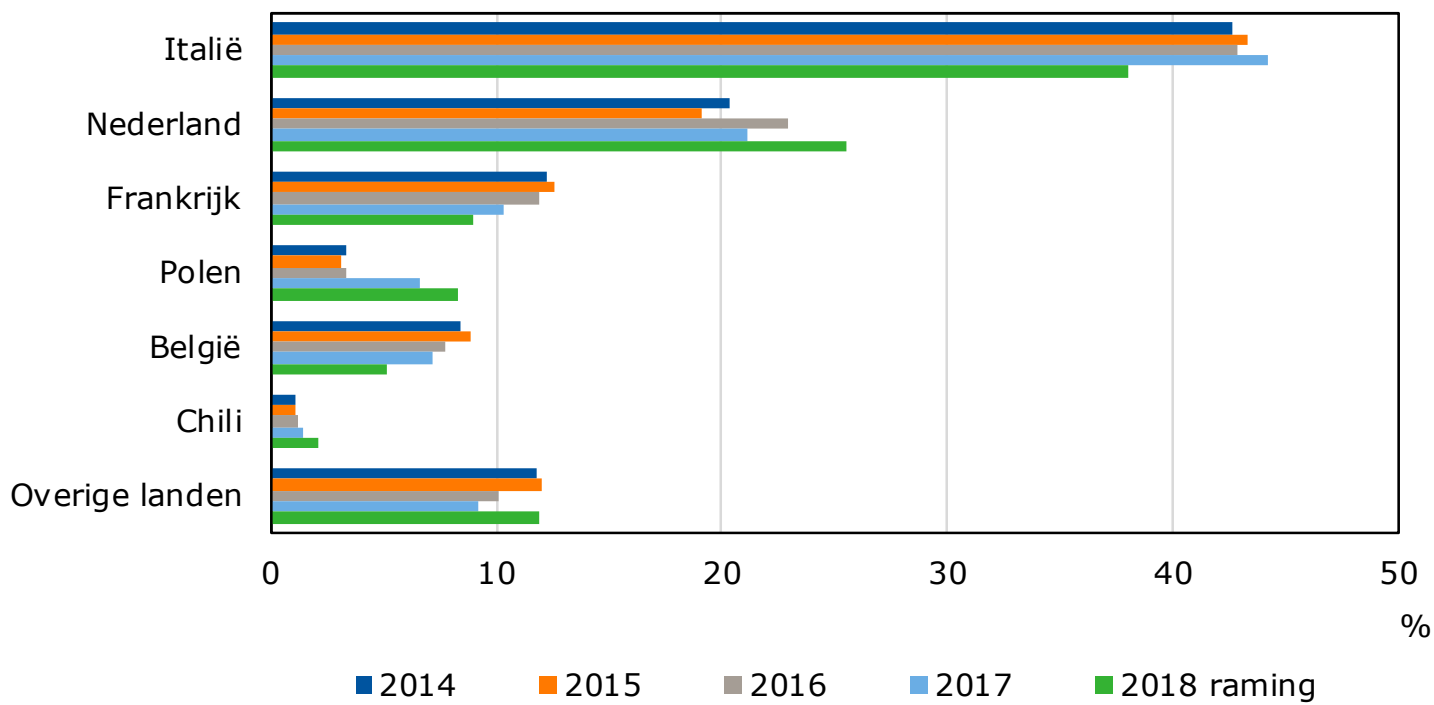

Figuur 3.4 Aandeel van de belangrijkste herkomstlanden in de Duitse import van appels. Bron: Comext/Eurostat tot en met september 2018, raming oktober - december 2018 door WUR en CBS.

\subsection{Positieve handelsbalans voor export van bevroren aardappelproducten uit Nederland}

Nederland heeft een positieve handelsbalans van 1.271 miljoen euro voor bevroren aardappelproducten in 2018 (figuur. 3.5). De export van deze producten vindt voor een belangrijk deel (ruim 65\%) plaats binnen Europa. Duitsland is een belangrijke afnemer, met in 2018 een import van 190 miljoen euro aan bevroren aardappelproducten uit Nederland. Andersom gaat een kleiner volume bevroren aardappelproducten vanuit Duitsland naar Nederland, namelijk ter waarde van 44 miljoen euro.

Import

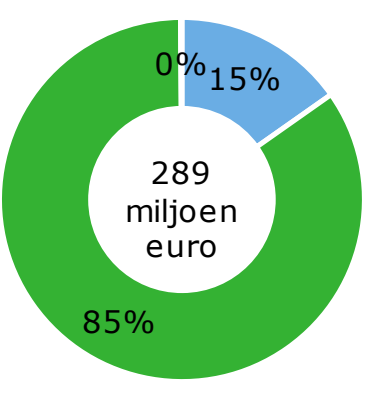

Duitsland
Handelsbalans

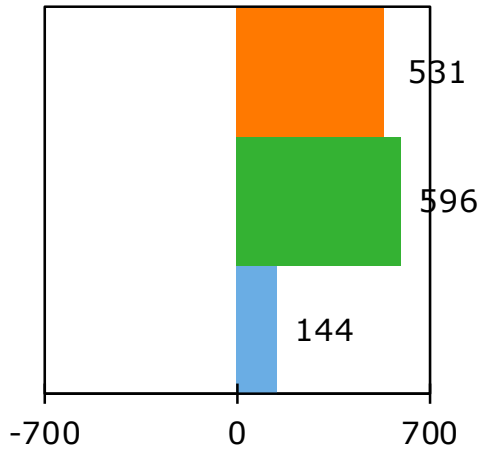

miljoen euro
Export

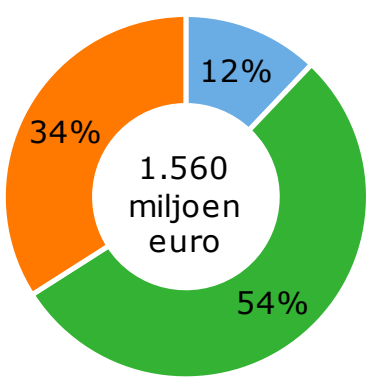

Figuur 3.5 Import en export van bevroren aardappelproducten in 2018 naar regio. Bron: CBS tot en met oktober 2018, raming november - december 2018 door WUR en CBS. 


\subsubsection{Nederlandse exportwaarde bevroren aardappelproducten gedaald}

Producten die binnen de productgroep bevroren aardappelproducten vallen, zijn bijvoorbeeld: frites, aardappelkroketjes, aardappelbolletjes, aardappelschijfjes, wedges, pommes Duchesse en rösti. Nederland is na België de grootste producent van diepgevroren aardappelproducten in Europa. Nederland levert voor meer dan 100 miljoen euro per land aan het Verenigd Koninkrijk, Duitsland en Frankrijk. Na het Verenigd Koninkrijk is Duitsland de belangrijkste Europese exportbestemming van diepgevroren aardappelproducten vanuit Nederland. Van de wereldwijd door Nederland geëxporteerde aardappelproducten is $87 \%$ van Nederlandse makelij. Voor de Nederlandse export naar Duitsland en de rest van Europa is dat aandeel respectievelijk $90 \%$ en $80 \%$.

De aardappelverwerkende industrieën in Nederland en België hebben de afgelopen periode fors geïnvesteerd in modernisering en uitbreiding van de productiecapaciteit. In 2017 verwerkte de Nederlandse aardappelverwerkende industrie een recordhoeveelheid aardappelen: voor het eerst in de geschiedenis werd de grens van 4 miljoen ton verwerkte aardappelen overschreden.

De exportwaarde van bevroren aardappelproducten naar Duitsland is in de periode 2010-2017 ruimschoots verdubbeld. In 2018 nam de totale waarde van de export van bevroren aardappelproducten uit Nederland voor het eerst af tot 1,6 miljard euro. De exportwaarde naar Duitsland daalde fors: $21 \%$ ten opzichte van 2017. De exportwaarde van Nederlandse bevroren aardappelproducten naar landen buiten de EU-28 is in 2018 toegenomen.

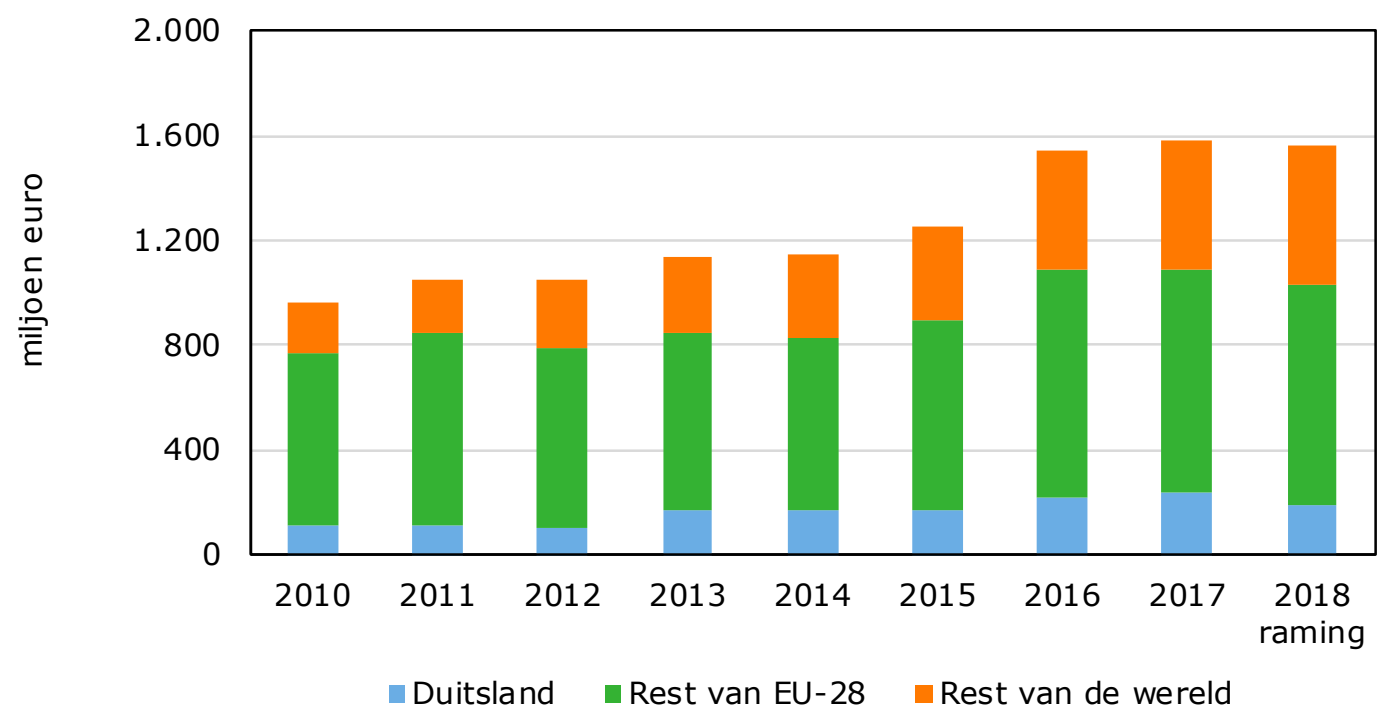

Figuur 3.6 Nederlandse export van bevroren aardappelproducten.

Bron: CBS tot en met oktober 2018, raming november - december 2018 door WUR en CBS. 


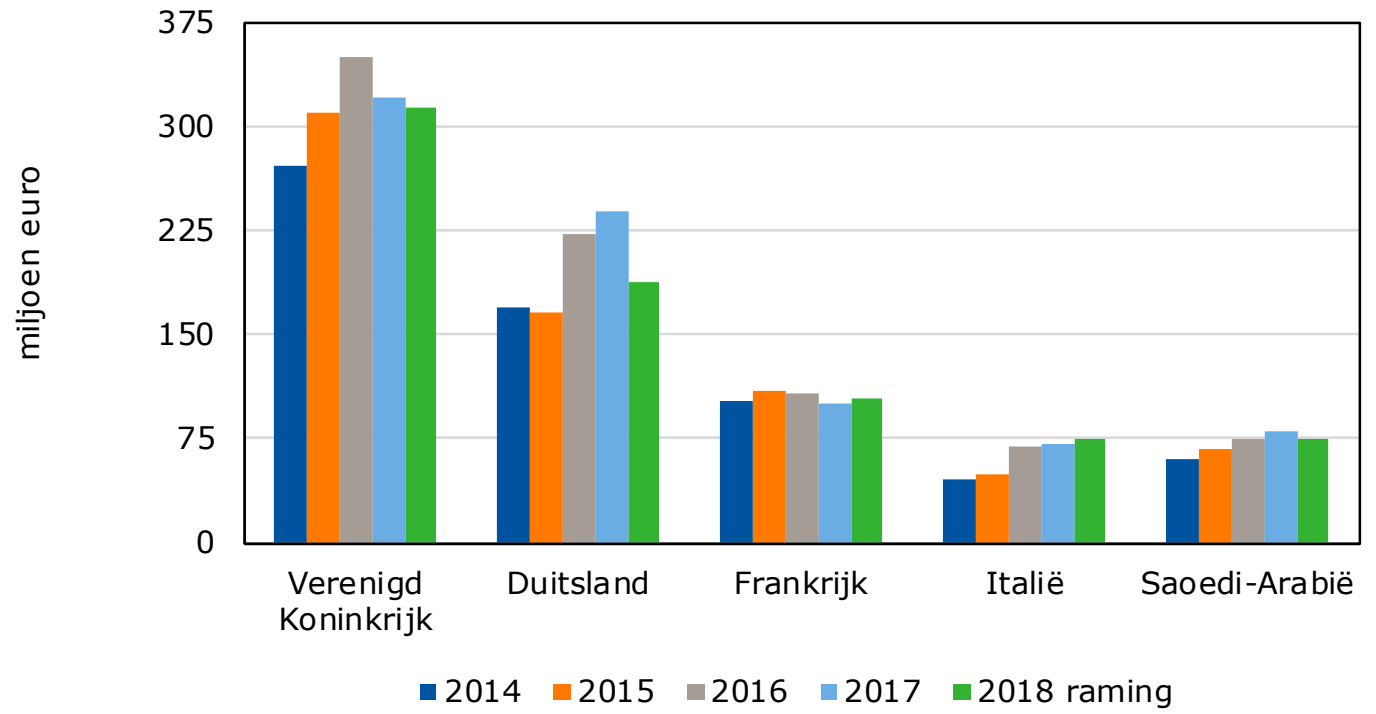

Figuur 3.7 Belangrijkste bestemmingen in de Nederlandse export van bevroren aardappelproducten.

Bron: CBS tot en met oktober 2018, raming november - december 2018 door WUR en CBS.

\subsubsection{Duitsland importeert bevroren aardappelproducten vooral uit Nederland}

Ongeveer drie kwart van de Nederlandse export bestaat uit frites. Nederland is veruit de belangrijkste handelspartner van Duitsland van diepgevroren aardappelproducten. Het Nederlandse aandeel van de Duitse import van diepgevroren aardappelproducten bedraagt $71 \%$ en nam in 2018 iets toe. Het (waarde)aandeel van de Duitse import vanuit België is aanzienlijk lager en daalde in 2018 naar $15 \%$. België is daarmee het tweede importland, gevolgd door Oostenrijk. Andere omringende landen, zoals Denemarken, Oostenrijk en Polen, zijn zeer bescheiden leveranciers van diepgevroren aardappelproducten voor de Duitse markt. Nederland heeft van oudsher een sterke positie op de Duitse markt: het levert kwaliteitsproducten in de duurdere marktsegmenten (onder andere fastfood). De sterk gegroeide Belgische aardappelverwerkende industrie concurreert vooral op prijs.

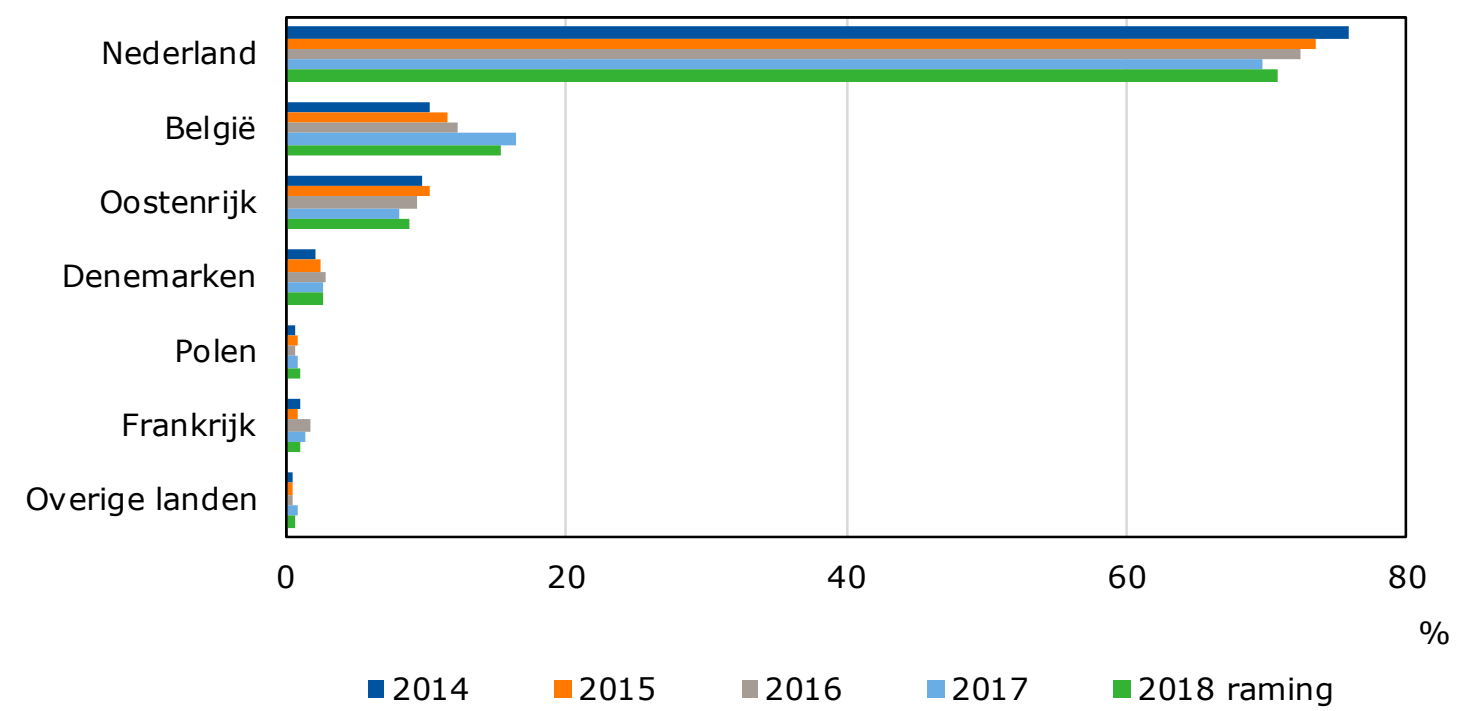

Figuur 3.8 Aandeel van de belangrijkste herkomstlanden in de Duitse import van bevroren aardappelproducten.

Bron: Comext/Eurostat tot en met september 2018, raming oktober - december 2018 door WUR en CBS. 


\subsection{Export tomaten flink lager}

Na het topjaar 2017 voor de Nederlandse tomatenexport heeft de export in 2018 een terugval gekend. De Nederlandse tomatenexport van 2018 is geraamd op 1.610 miljoen euro, wat een vermindering van $7,5 \%$ betekent. Daarmee ligt de geraamde exportwaarde in 2018 nog wel boven het niveau van 2016. Het beeld van 2018 is voornamelijk terug te voeren op het wegvallen van een deel van de consumptieve vraag naar Nederlandse tomaten in de zomermaanden en dan met name in Duitsland. Het aandeel van de Nederlandse export naar Duitsland is met 47,5\% iets lager dan in 2017 . Het saldo op de handelsbalans is voor 2018 geraamd op 1.345 miljoen euro. Ten opzichte van 2017 is de handelsbalans met 85 miljoen euro verslechterd. Er is minder geëxporteerd en ook minder geïmporteerd.

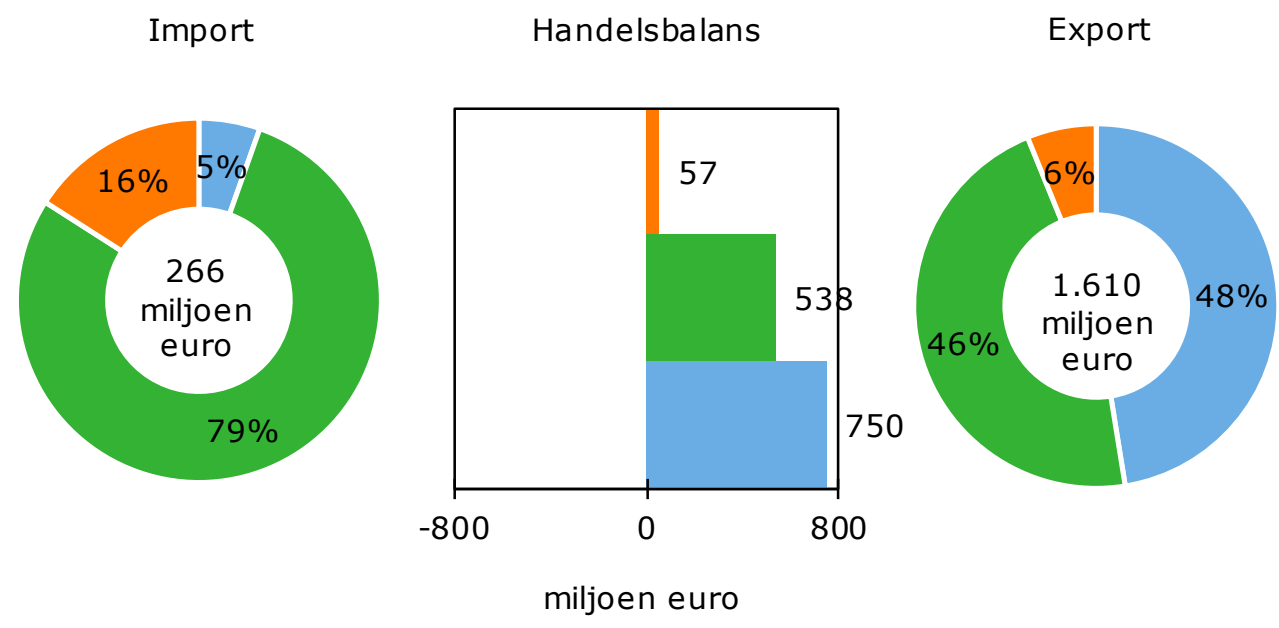

Duitsland $\quad$ Rest van EU-28 $\quad$ Rest van de wereld

Figuur 3.9 Import en export van tomaten in 2018 naar regio.

Bron: CBS tot en met oktober 2018, raming november - december 2018 door WUR en CBS.

Zowel de export als de import van Nederland is teruggelopen, wat duidt op een achterblijvende vraag. Als gevolg daarvan is het Nederlandse overschot op de handelsbalans met 1.345 miljoen euro 6\% lager dan in 2017. Met name de afgenomen export naar Duitsland draagt daaraan bij (-9\%).

\subsubsection{Exportwaarde naar Duitsland valt terug}

Vanaf januari 2018 heeft de internationale tomatenmarkt in 2018 in het teken gestaan van stagnerende vraag en veel aanbod, met als resultaat lagere prijzen. De teruggang in exportwaarde is het grootst geweest op de Duitse markt (-9\%). De teruggang in exportwaarde naar de overige EUlanden bedraagt een kleine 4\%. Door het warme weer was de Nederlandse productie weliswaar hoog, maar de kwaliteit werd minder naarmate het aanbodseizoen vorderde.

Het toepassen van assimilatiebelichting leidt in de tomatenteelt tot een totaal ander afzetpatroon ten opzichte van de gangbare teelt, waarbij belichte Nederlandse tomaten vanaf januari aan de markt zijn. Circa 30\% van het Nederlandse tomatenareaal wordt momenteel onder belichting geteeld. De laatste jaren is het areaal onder belichting sterk uitgebreid. Dat was tot en met vorig jaar ook rendabel (GF actueel 27-6-2017, Ellis Langen 2014, Wageningen Economic Research 2018). In 2018 waren vanaf januari de prijzen tegenvallend, wat mogelijk duidt op overproductie in de eerste maanden van het jaar. 


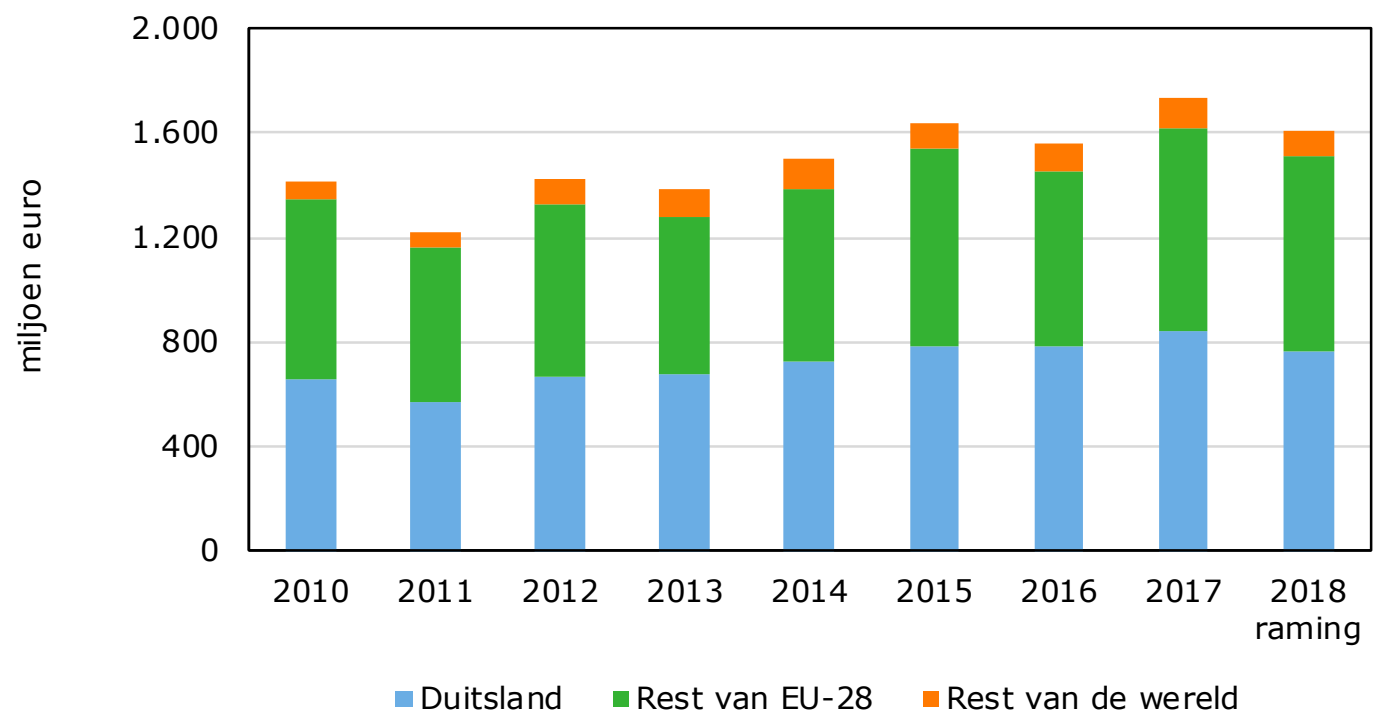

Figuur 3.10 Nederlandse export van tomaten.

Bron: CBS tot en met oktober 2018, raming november - december 2018 door WUR en CBS.

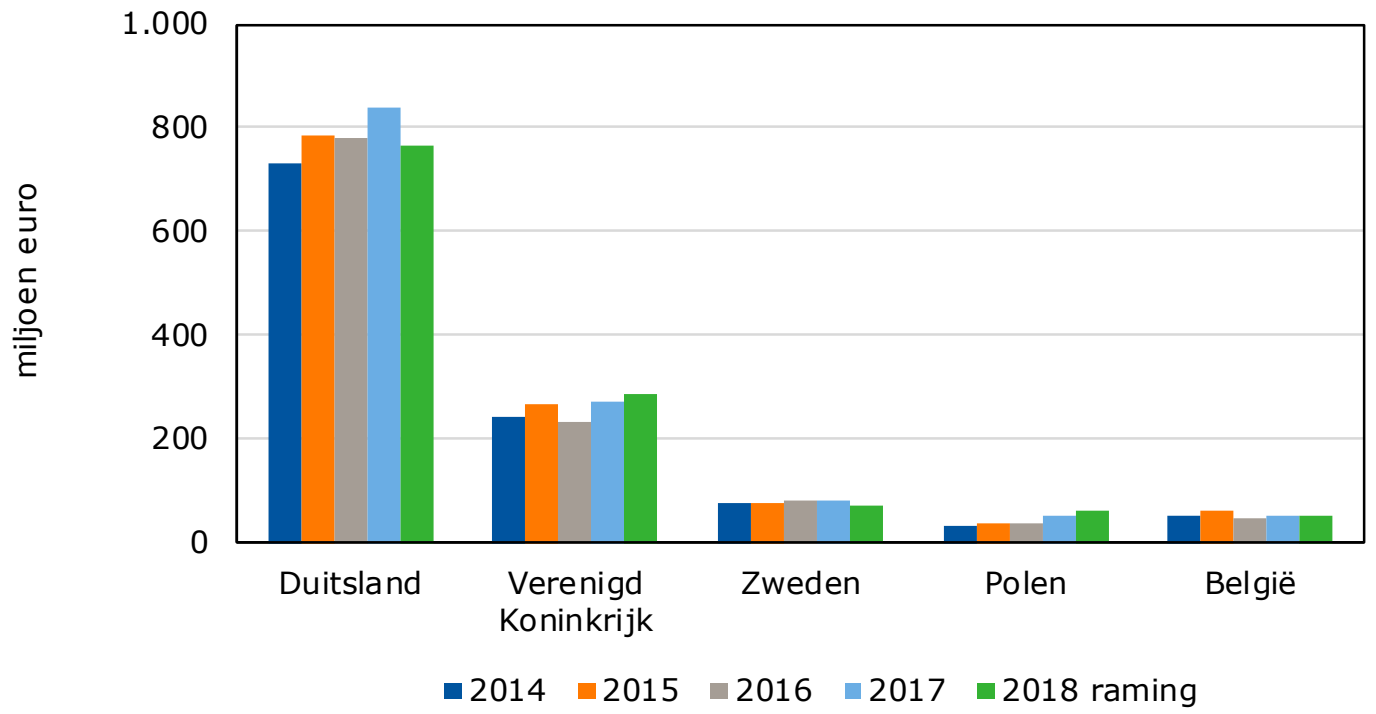

Figuur 3.11 Belangrijkste bestemmingen in de Nederlandse export van tomaten.

Bron: CBS tot en met oktober 2018, raming november - december 2018 door WUR en CBS.

\section{Export naar Verenigd koninkrijk groeit}

Ondanks de voor Nederland ongunstige koers van het pond, is het exportaandeel naar het Verenigd koninkrijk (VK) in 2018 hoger geraamd dan in 2017 (+4\%). Het VK blijft met ruim verschil het op één na belangrijkste exportland voor Nederlandse tomaten. De export naar Zweden heeft in 2018 een dip gekend (-12\%). Gezien de stabiele export in de jaren voor 2018 lijkt dit een incident. De export naar Polen blijft zich onverminderd ontwikkelen $(+20 \%)$, ondanks een behoorlijke eigen productie. De exportwaarde naar België is iets gedaald $(-5 \%)$.

\section{Afgenomen vraag leidt tot dalende import Nederland}

De afgenomen Nederlandse vraag in 2018 leidde ook tot afgenomen import (-12\%). De import uit de $\mathrm{EU}$ is veel meer afgenomen (vooral uit Spanje) dan de import uit de rest van de wereld $(-8 \%)$. 


\subsubsection{Marktaandeel naar Duitsland daalt licht}

Op de Duitse markt hebben Nederlandse tomaten in 2018 met 58\% het grootste marktaandeel. Het marktaandeel daalde wel met 2\%. De totale importwaarde van Duitsland bedraagt in 2018 bijna 1.230 miljoen euro. Dit is 7\% lager dan in 2017. Het aandeel Spaanse tomaten op de Duitse markt is met $2 \%$ toegenomen en bedraagt $25 \%$. Het marktaandeel van Frankrijk en Italië neemt gestaag af en de export van die landen in 2018 volgt deze trend. Het marktaandeel van België neemt gestaag toe.

Nederlandse tomaten onderscheiden zich van buitenlandse door een constante kwaliteit en diversiteit in soorten. Tijdens de teelt is gewasbescherming met chemische middelen noodzakelijk, maar het gebruik ervan neemt af (Bedrijveninformatienet 2017, kg werkzame stof). Het residuenniveau op tomaten is een belangrijk kwaliteitscriterium. De kwaliteits- en residueisen van de retail en consument in Duitsland zijn hoog. Nederland heeft op de Duitse markt een sterke positie en doet er alles aan om aan deze eisen te blijven voldoen. Door de warme omstandigheden in de zomer van 2018 was het voor bedrijven moeilijk de kwaliteit op goed niveau te houden.

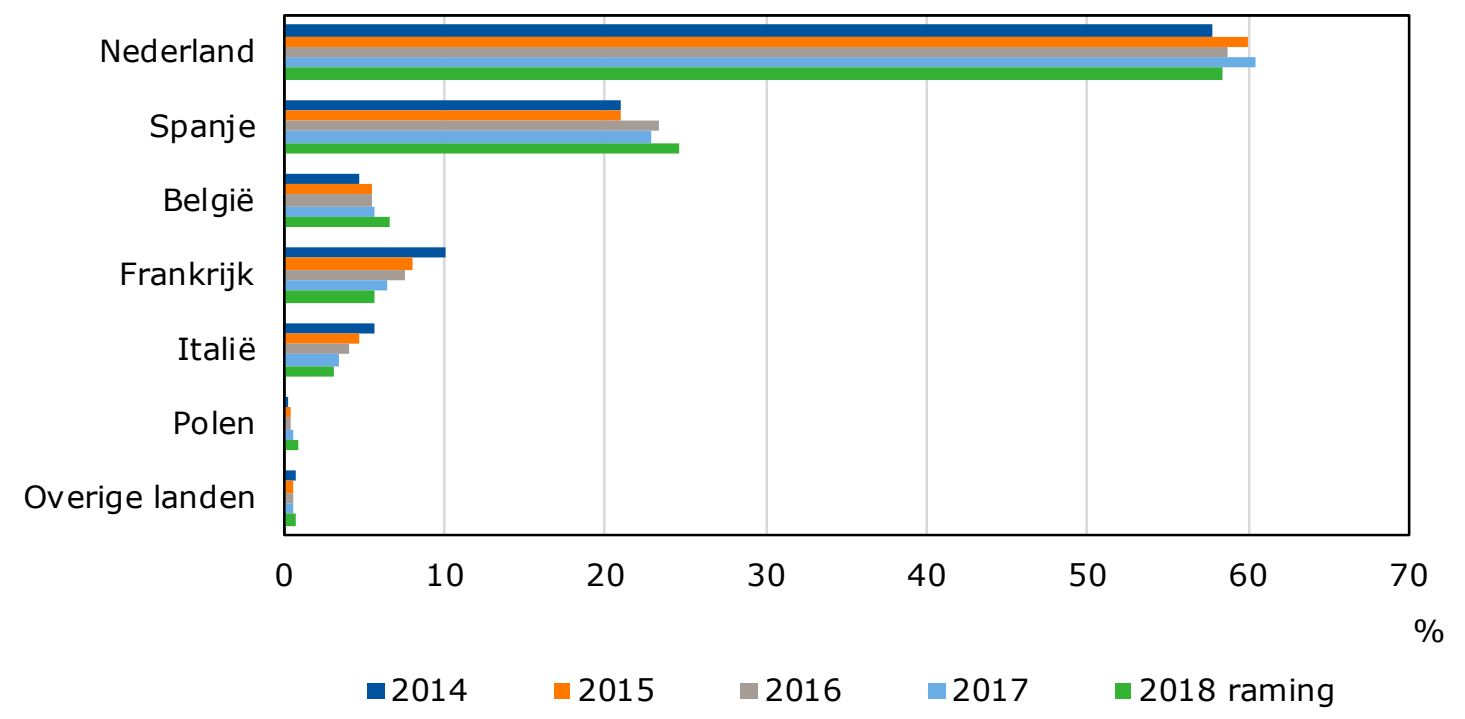

Figuur 3.12 Aandeel van de belangrijkste herkomstlanden in de Duitse import van tomaten. Bron: Comext/Eurostat tot en met september 2018, raming oktober-december 2018 door WUR en CBS. 


\subsection{Export snijbloemen ondanks warme zomer gegroeid}

De Nederlandse exportwaarde van snijbloemen is met 3.716 miljoen euro 89 miljoen euro hoger dan in 2017. Daartegenover staat dat er met 861 miljoen euro aan waarde 48 miljoen euro minder import is geweest. In de exportbestemmingen zijn weinig verschuivingen geweest. Bijna $30 \%$ van de Nederlandse exportwaarde is naar Duitsland gegaan. De import komt vooral uit de rest van de wereld en dan vooral uit Afrikaanse landen. Per saldo is het overschot op de handelsbalans ten opzichte van 2017 met 5\% gestegen. Doordat de afzet van snijbloemen sterk exportgeoriënteerd is, is het belangrijk om te voldoen aan fytosanitaire voorwaarden. In dit kader is het voldoen aan de 0-tolerantie-eis van groot belang. 0-tolerantie houdt in dat voor organismen die op de zogenaamde quarantainelijst staan van het land waar naartoe wordt geëxporteerd, geldt dat deze organismen niet in het geëxporteerde product mogen worden aangetroffen. Het kunnen voldoen aan fytosanitaire eisen zal in verband met het door regelgeving beperktere middelenpakket in de toekomst problematisch kunnen worden als geen nieuwe innovaties op dat terrein worden geïntroduceerd. Bedrijven die met een beperkter middelenpakket in de toekomst aan fytosanitaire eisen kunnen voldoen, zijn spekkoper. De verwachting is dat het behalen van de 0-tolerantie bij de teelt van biologische bloemen hierdoor nog moeilijker wordt en dan ook geen grote vlucht zal nemen.

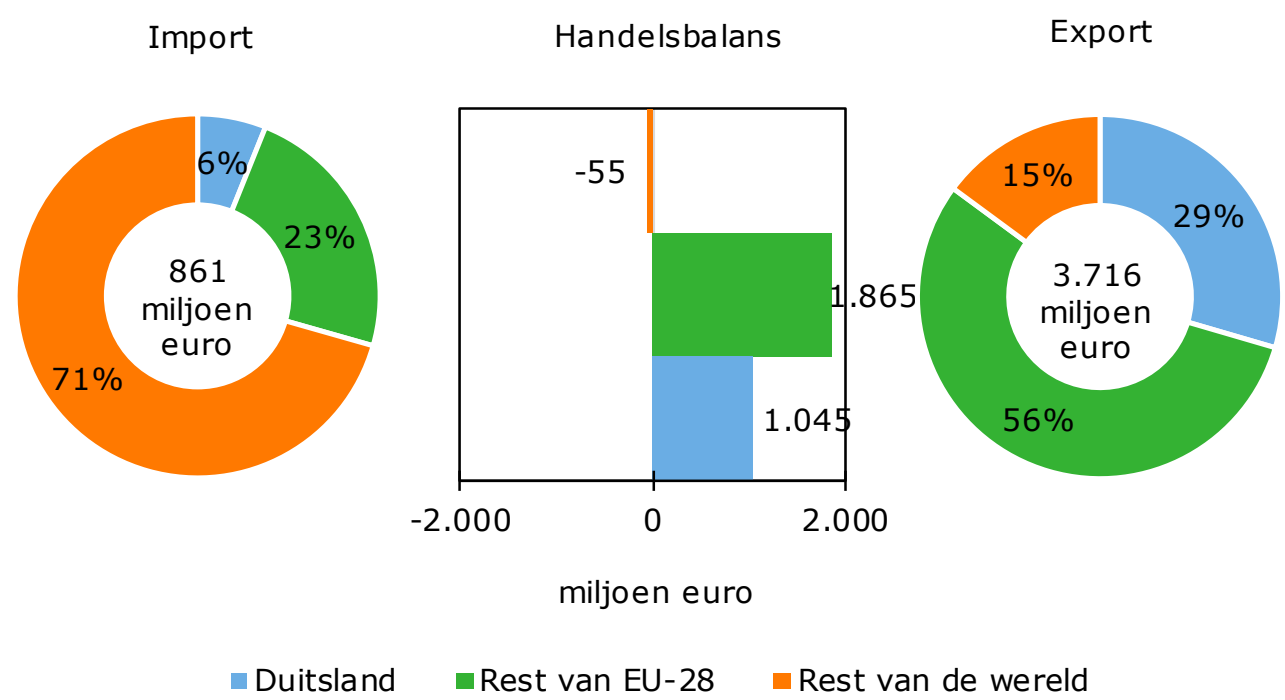

Figuur 3.13 Import en export van snijbloemen in 2018 naar regio.

Bron: CBS tot en met oktober 2018, raming november - december 2018 door WUR en CBS.

\subsubsection{Export snijbloemen na zomerdip hersteld}

Door het langdurige warme weer in heel West-Europa viel van mei tot en met augustus een deel van de vraag weg, met lage prijzen en lagere exportvolumes tot gevolg. Vanaf oktober herstelde de vraag, waarbij over het geheel genomen de export in deze maand goed was. De exportwaarde naar Duitsland, met afstand het grootste exportland voor snijbloemen, volgt het geschetste algemene beeld. Na september is hier het herstel ingetreden.

\section{Export Verenigd koninkrijk iets lager}

Sinds de Brexit-stemming in 2016 is de koers van het pond drastisch gedaald. Prijsverhogingen op de Britse markt leidden ertoe dat consumenten meer goedkopere bloemen kochten, waardoor de export naar het VK voor Nederlandse exporteurs moeizamer werd. Onzeker is hoe de export naar het VK in de toekomst zal verlopen. Nederlandse exporteurs hebben zorgen over tijdige afwikkeling van grensprocedures en fytosanitaire eisen. De export naar het VK is voor 2018 geraamd op 514 miljoen euro. Dit is ruim 2\% lager ten opzichte van de export in 2017. 


\section{Export Frankrijk toont bescheiden groei}

Voor de export naar Frankrijk is oktober een goede maand geweest. Daarmee werd enigszins ingelopen op de achterstand die in de zomermaanden ontstond. De totale export naar Frankrijk is geraamd op 461 miljoen euro, wat een evenaring van het resultaat van het jaar ervoor betekent.

\section{Markt Polen steeds belangrijker}

De export naar Rusland is met 175 miljoen euro het niveau van 2014 gepasseerd.

Van de overige landen zit vooral de export naar Polen de laatste vijf jaar in de lift. In 2018 is de export naar Polen geraamd op 152 miljoen euro (groei 10\%).

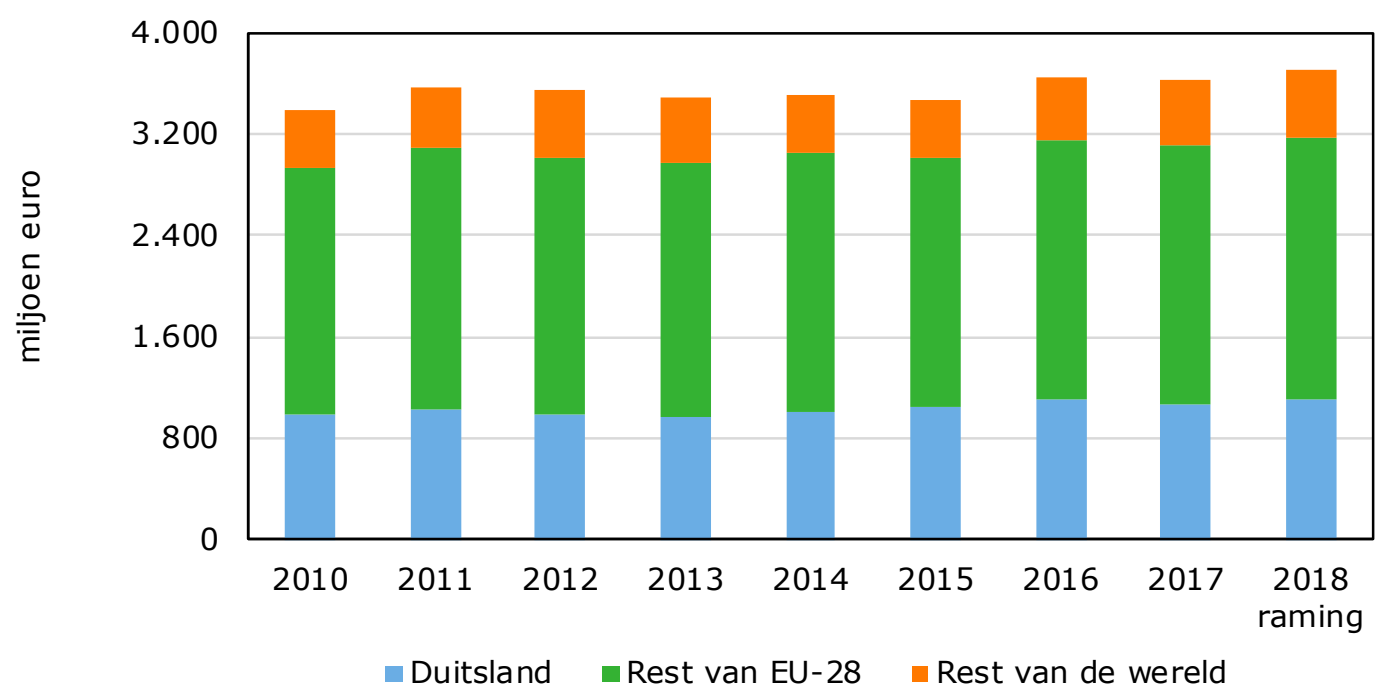

Figuur 3.14 Nederlandse export van snijbloemen.

Bron: CBS tot en met oktober 2018, raming november - december 2018 door WUR en CBS.

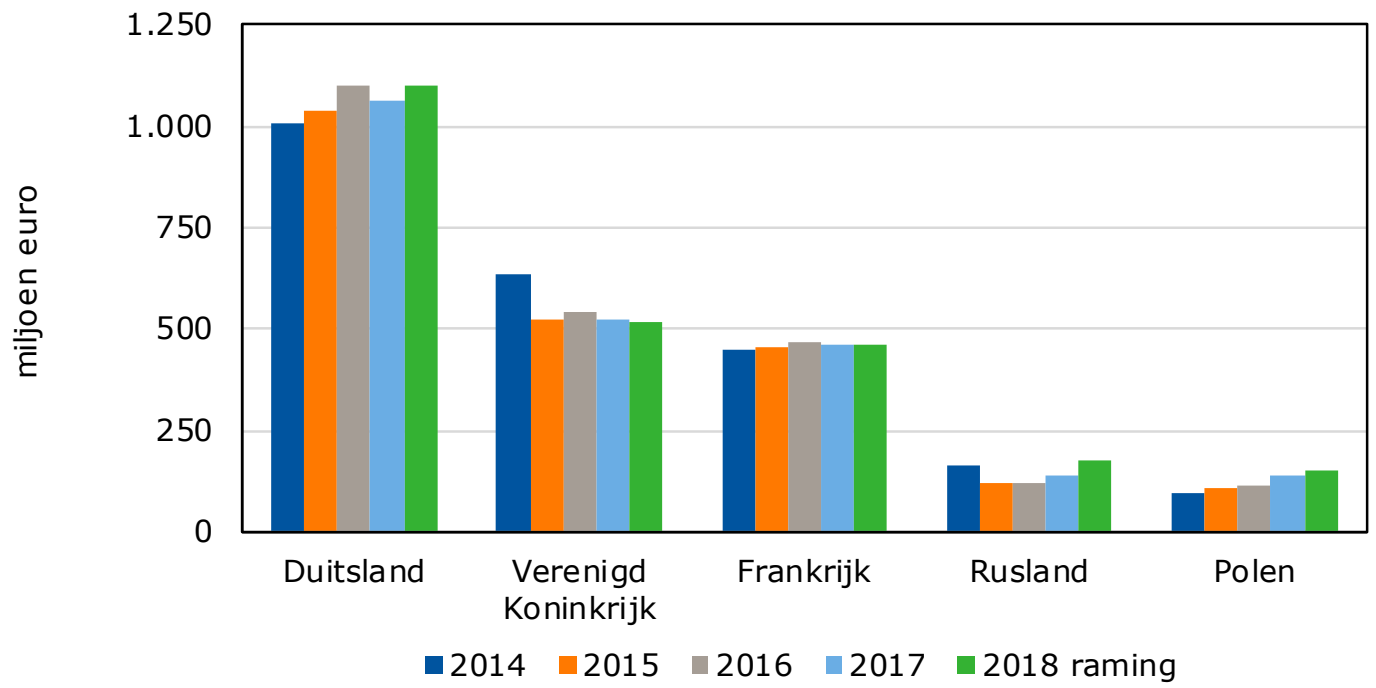

Figuur 3.15 Belangrijkste bestemmingen in de Nederlandse export van snijbloemen.

Bron: CBS tot en met oktober 2018, raming november - december 2018 door WUR en CBS. 


\subsubsection{Marktaandeel snijbloemen in Duitsland onverminderd groot}

Het aandeel van Nederland op de Duitse markt is in 2018 geraamd op 92\%, een even groot aandeel ten opzichte van 2017. In 2016 was dit aandeel nog 91\%. Het toegenomen aandeel van Nederlandse bloemen is ten koste gegaan van de export uit de overige landen. Het al kleine deel dat uit Polen afkomstig was, is in deze periode verder afgenomen. Binnen de categorie 'Overige landen' heeft Ethiopië een belangrijk aandeel.

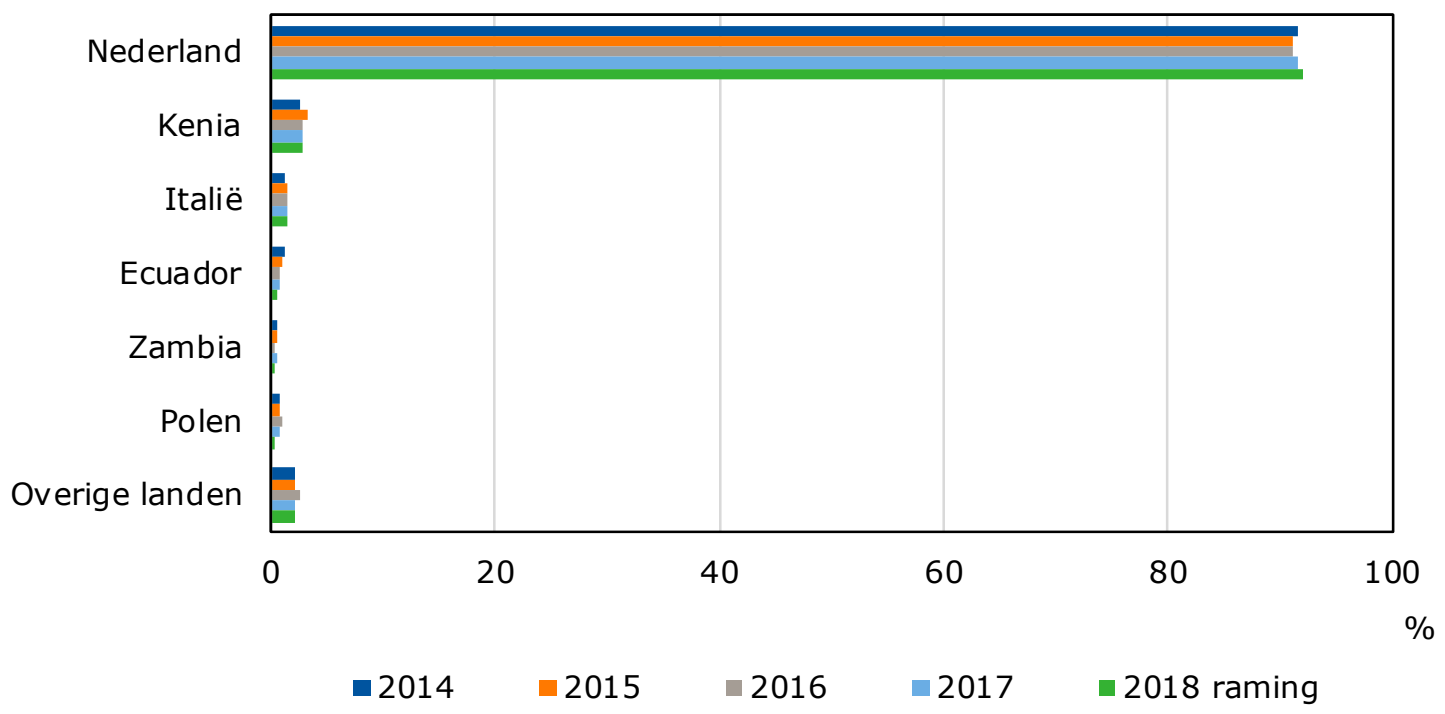

Figuur 3.16 Aandeel van de belangrijkste herkomstlanden in de Duitse import van snijbloemen. Bron: Comext/Eurostat tot en met september 2018, raming oktober-december 2018 door WUR en CBS.

\section{Import naar Nederland afgenomen}

Nederland importeert een substantiële omzet aan snijbloemen uit derde landen. Deze import bedraagt 873 miljoen euro en is in 2018 met $10 \%$ afgenomen Dit is een gevolg van een verminderde vraag in de zomerperiode ten opzichte van voorgaande jaren. Het grootste deel van de geïmporteerde bloemen wordt verwerkt tot gemengde boeketten. 


\subsection{Exportgroei boomkwekerijproducten zet in 2018 door}

De exportwaarde van boomkwekerijproducten uit Nederland zal naar verwachting met 7\% groeien. Dit is vooral het resultaat van een gemiddeld hogere waarde van producten. Na stagnatie in de periode 2014 en 2015 door uitval in de keten, lijkt het herstel van Duitsland als exportbestemming structureel van aard. In 2018 nam ook de export naar België en Frankrijk en Oost-Europese en Scandinavische bestemmingen toe. Export naar het Verenigd Koninkrijk maakte in 2018 vanwege vooral de Brexitveranderingen pas op de plaats.
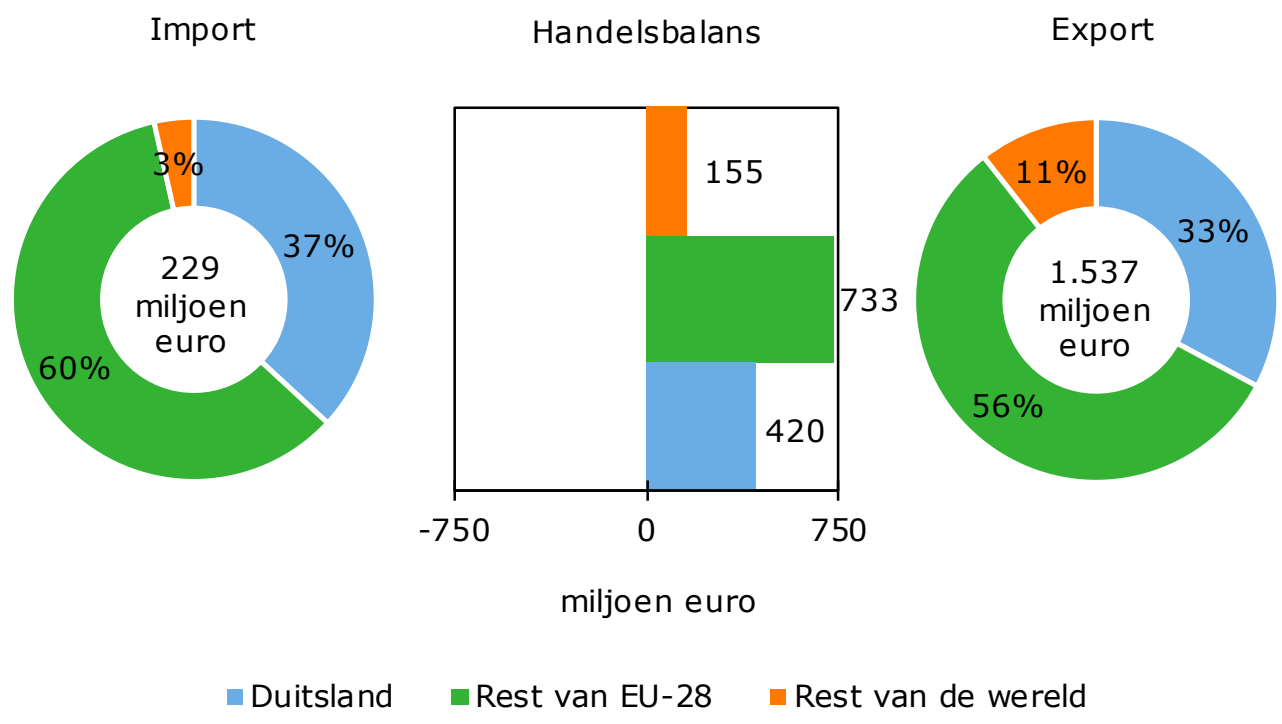

Figuur 3.17 Import en export van boomkwekerijproducten in 2018 naar regio.

Bron: CBS tot en met oktober 2018, raming november - december 2018 door WUR en CBS.

Omdat de waarde van de import van boomkwekerijproducten door Nederland beperkt is, heeft deze ook beperkt invloed op de handelsbalans. Het overschot op de handelsbalans groeide met 5\%. Er was enerzijds een gemiddeld hogere prijswaardering van het Nederlands boomkwekerijproduct, anderzijds was er meer import.

Import van boomkwekerijproducten komt hoofzakelijk uit de logistiek aantrekkelijk gelegen buurlanden. Van de totale invoer in Nederland kwam 37\% uit Duitsland. Dit aandeel is in 2018 iets gedaald ten opzichte van 2017, ondanks dat er in absolute zin meer werd geïmporteerd. Dit kwam doordat de totale import door Nederland sterker steeg.

\subsubsection{Export Nederlandse boomkwekerijproducten naar Duitsland neemt verder toe}

De totale export van Nederlandse boomkwekerijproducten met bestemming Duitsland is met $10 \%$ verder gegroeid. De vraag en waardering van Nederlandse boomkwekerijproducten in Duitsland hebben hiermee een groot aandeel in het herstel van de Nederlandse boomkwekerijsector. In 2018 waren verder de Scandinavische en Oost-Europese landen belangrijk, net als België en Frankrijk.

Na de periode 2014-2015, waarin uitval van ketenpartijen een belangrijke impact hadden op de export naar Duitsland, lijkt de exportwaarde van Nederlandse boomkwekerijproducten op de Duitse markt structureel hersteld. Dit komt vooral door vraaggerichte productie en doordat, na enkele faillissementen, het vertrouwen in de afzetketen is hersteld.

Vraaggerichte productie van boomkwekerijproducten, voldoen aan residueisen en levering van kwaliteit en hoge sierwaarde op het door de klant gewenste moment werden in 2018 beloond met een 
verbeterde prijs. Vooral boomkwekerijbedrijven die kwekersvaardigheid combineerden met een goed netwerk en assortiment, konden hiervan profiteren.

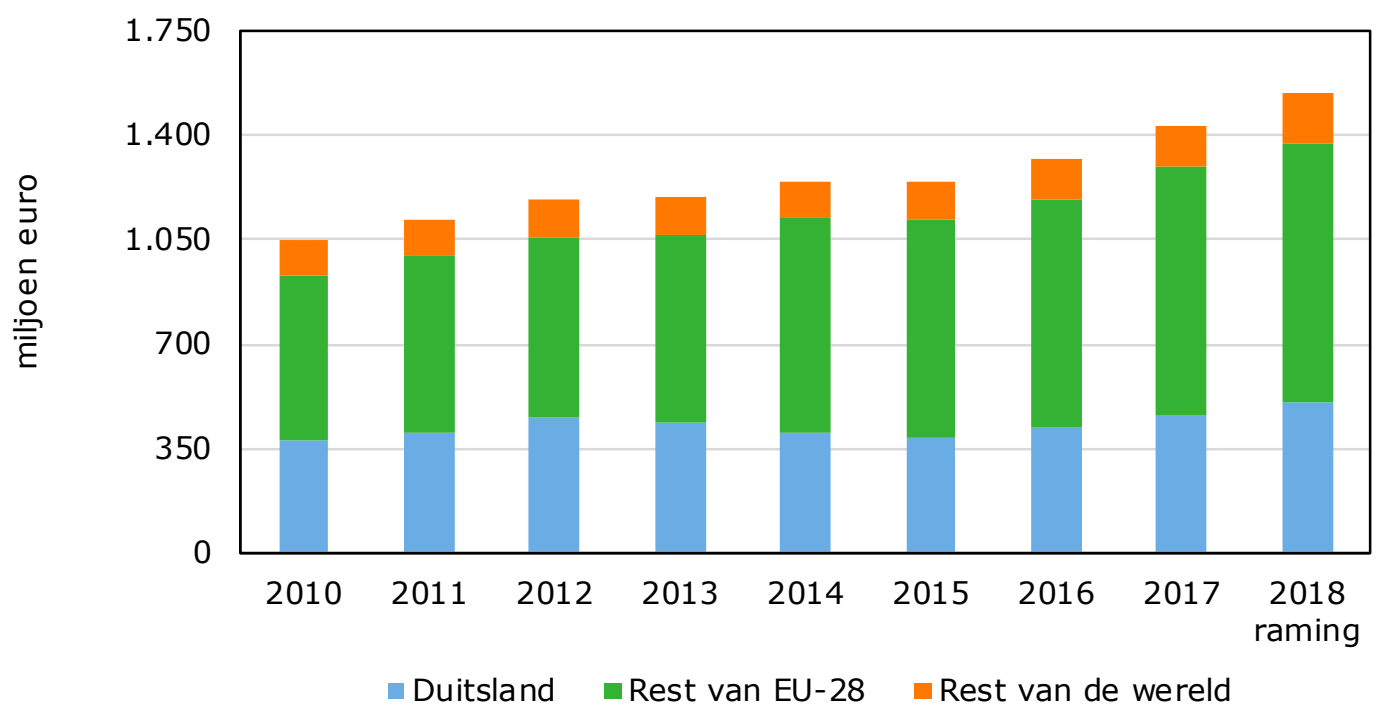

Figuur 3.18 Nederlandse export van boomkwekerijproducten.

Bron: CBS tot en met oktober 2018, raming november - december 2018 door WUR en CBS.

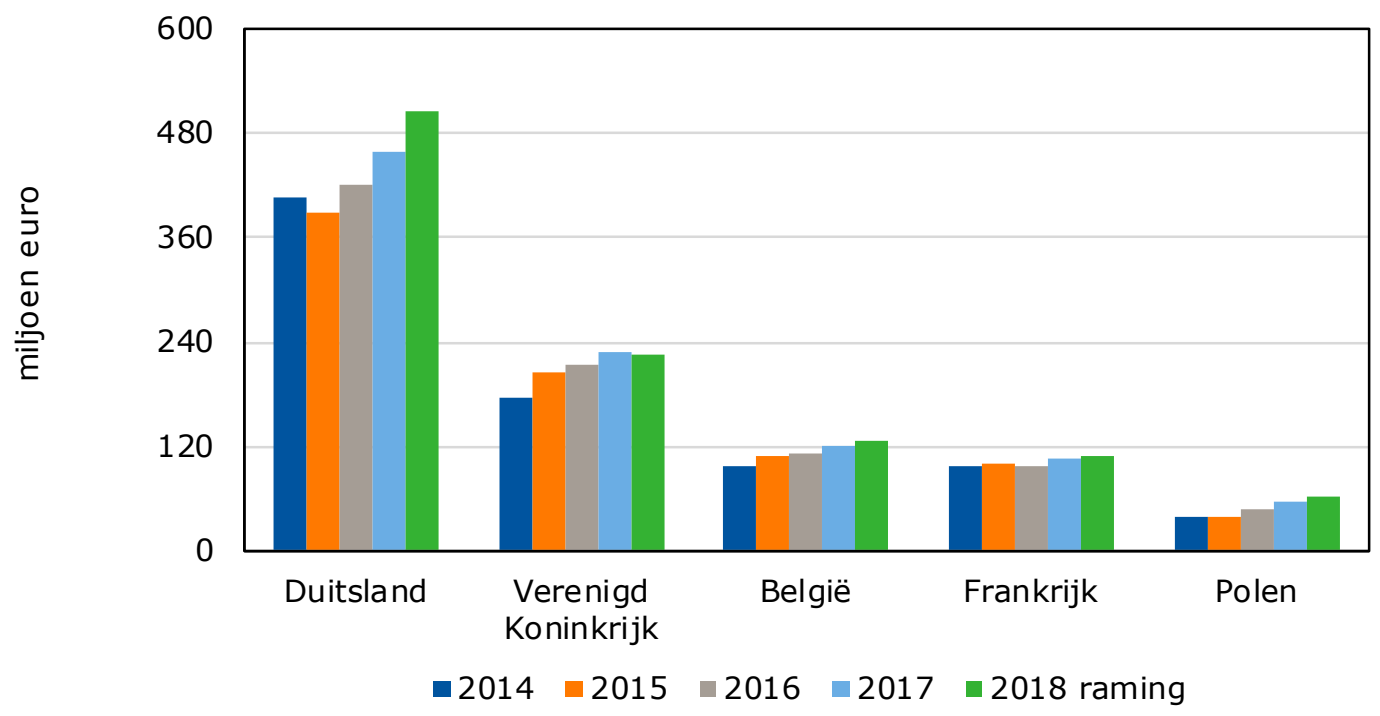

Figuur 3.19 Belangrijkste bestemmingen in de Nederlandse export van boomkwekerijproducten. Bron: CBS tot en met oktober 2018, raming november - december 2018 door WUR en CBS.

\subsubsection{Groei aandeel Nederlandse boomkwekerijproducten in Duitse import zet door}

De totale importwaarde van boomkwekerijproducten in Duitsland bleef in 2018 globaal gelijk. De waarde van de importwaarde van Nederlandse herkomst groeide wel, met $1 \%$. Hiermee blijft Nederland veruit de belangrijkste importpartner voor Duitse afnemers. Het marktaandeel is de laatste jaren gegroeid van $76 \%$ naar bijna $79 \%$. Hieraan ligt de vraag naar producten met een hogere waarde, waar Nederlandse kwekers een sterke positie in hebben, ten grondslag. 


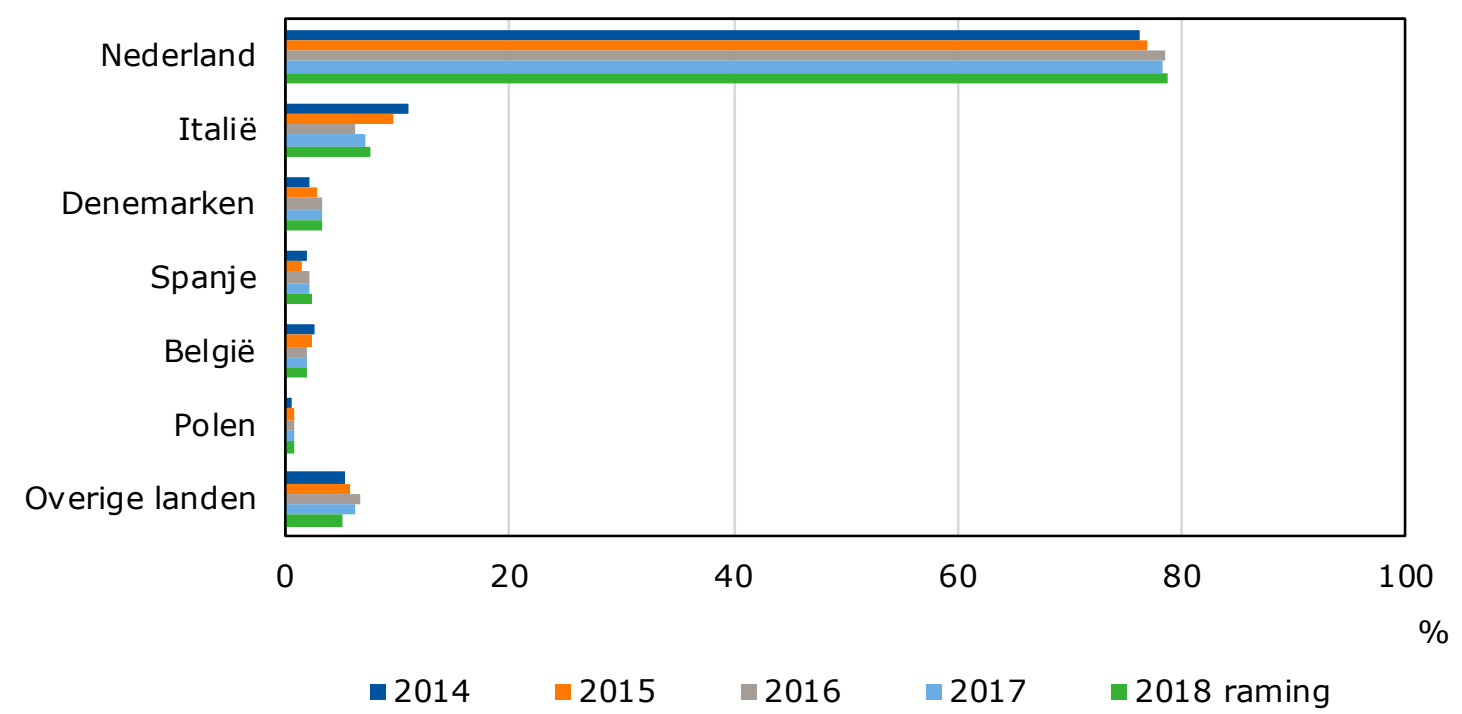

Figuur 3.20 Aandeel van de belangrijkste herkomstlanden in de Duitse import van boomkwekerijproducten.

Bron: Comext/Eurostat tot en met september 2018, raming oktober-december 2018 door WUR en CBS.

\subsection{Exportwaarde kaas 2\% gedaald in 2018}

De totale waarde van de Nederlandse kaasexport is in 2018 met 63 miljoen euro licht gedaald tot 3,5 miljard (figuur 3.21 en 3.22). Dit is een daling van $2 \%$ ten opzichte van 2017 . Een derde van alle geëxporteerde kaas ging in 2018 naar Duitsland. De totale waarde van de invoer van kaas is 1,3 miljard euro: een stijging van 18 miljoen (ruim 1\%) ten opzichte van 2017.

Import

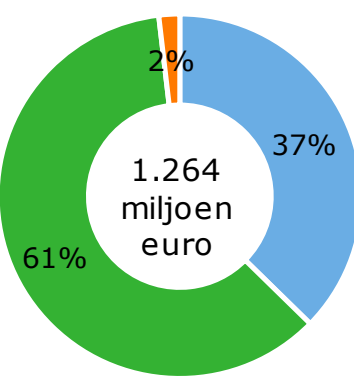

Handelsbalans

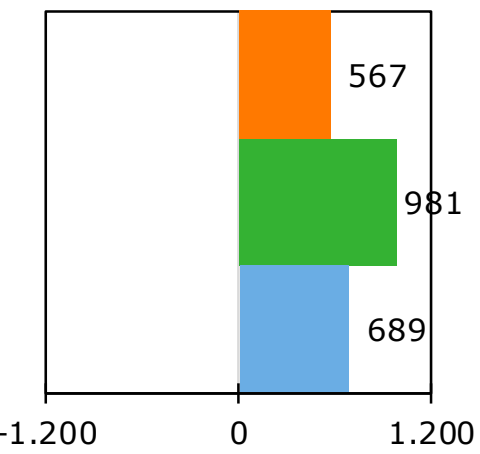

miljoen euro

Export

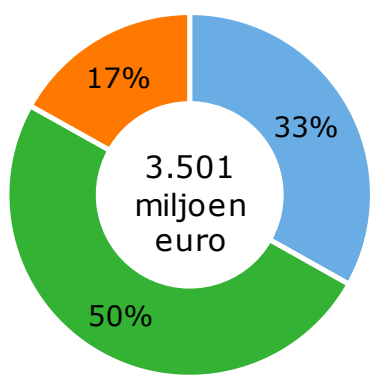

Duitsland $\quad$ Rest van EU-28 $\quad$ Rest van de wereld

Figuur 3.21 Import en export van kaas in 2018 naar regio.

Bron: CBS tot en met oktober 2018, raming november - december 2018 door WUR en CBS. 


\subsubsection{2/3 van Nederlandse kaasexport gaat naar vijf landen}

Andere belangrijke bestemmingen binnen de EU voor Nederlandse kaas zijn België en Frankrijk, met een aandeel in de totale exportwaarde van respectievelijk $12,5 \%$ en $10 \%$ (figuur 3.23). Het aandeel naar die landen stijgt ook in de loop van de tijd (na soms een dipje in tussenliggende jaren). De verminderde uitvoer naar EU-Ianden van 61 miljoen euro is voor het grootste deel verantwoordelijk voor de totale daling van 63 miljoen euro van de waarde van de door Nederland uitgevoerde kaas.

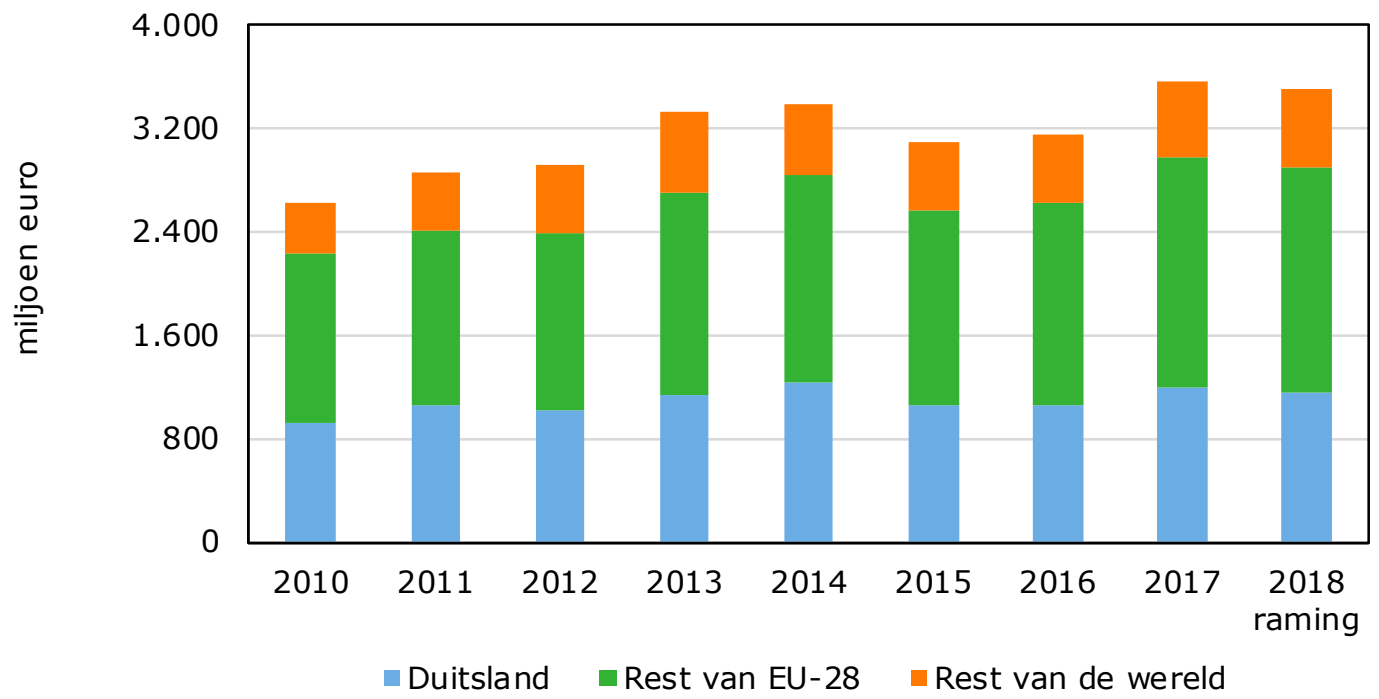

Figuur 3.22 Nederlandse export van kaas.

Bron: CBS tot en met oktober 2018, raming november - december 2018 door WUR en CBS.

De belangrijkste Nederlandse exportbestemmingen voor kaas buiten Europa zijn de Verenigde Staten en Japan, met een gezamenlijk aandeel van iets minder dan 5\%. De exportwaarde van kaas naar Japan is in 2018 nauwelijks veranderd in vergelijking met het voorgaande jaar, maar 62\% gestegen ten opzichte van 2016. De verwachting is dat de export van kaas uit de EU naar Japan in de toekomst een impuls krijgt als gevolg van het onlangs gesloten handelsakkoord JEFTA (NOS, 2017). De kaasexport naar de Verenigde Staten is vrij stabiel. De export naar Rusland is in 2015 door de Russische boycot stil komen te liggen. In 2013 werd er nog voor 233 miljoen euro aan kaas naar Rusland geëxporteerd. De export van kaas bestaat voor $84 \%$ uit goederen van Nederlandse makelij en voor 16\% uit wederuitvoer. Tussen 2010 en 2018 is naar verhouding meer kaas geëxporteerd naar Slowakije en Roemenië (met respectievelijk een factor 10 en 6), maar het aandeel van die landen in de totale export is met een paar tienden van procenten nog steeds verwaarloosbaar.

\section{Minder geëxporteerde kaas}

De afname van de Nederlandse kaashandelswaarde wordt veroorzaakt door lagere exportvolumes. Enkele kaassoorten, zoals Goudse en Edammer kaas, zijn in 2018 lager geprijsd, maar over de hele linie is de oorzaak van de lagere exportwaarde het volume. In Nederland wordt in 2018 naar verwachting ook $2 \%$ minder melk geproduceerd, zodat, zoals het er nu naar uit ziet, een evenredig kleiner deel tot kaas wordt verwerkt. 


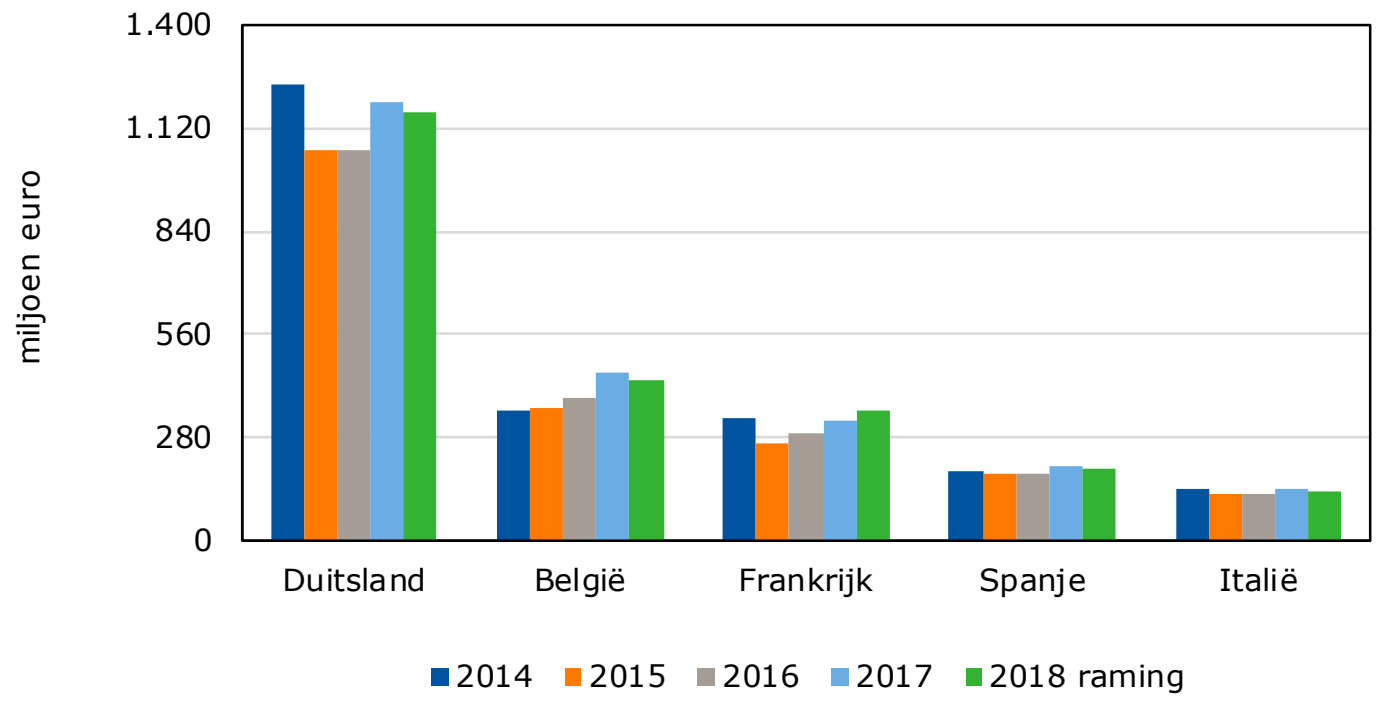

Figuur 3.23 Belangrijkste bestemmingen in de Nederlandse export van kaas.

Bron: CBS tot en met oktober 2018, raming november - december 2018 door WUR en CBS.

\subsubsection{Nederland belangrijkste handelspartner voor Duitse kaasimport}

In 2018 werd er in Duitsland voor 3,7 miljard euro aan kaas geïmporteerd, een daling van $2 \%$ ten opzichte van 2017. De zes genoemde landen in figuur 3.24 hebben een aandeel van $83 \%$ in de totale kaasinvoer in Duitsland. Nederland is voor Duitsland een belangrijk herkomstland, met een aandeel van bijna $30 \%$ over de laatste jaren. Na Nederland is Frankrijk, met een aandeel van $19 \%$, het belangrijkste land in de Duitse import. De totale importwaarde aan kaas in Duitsland neemt over het algemeen toe, al was in 2015 en 2016 een dip waarneembaar vanwege relatief lage prijzen voor kaas. Ten opzichte van 2010 nam de import van Duitsland uit Nederland toe met ruim 4\%. Het aandeel van de herkomstlanden is over het algemeen vrij stabiel, al neemt het aandeel van Frankrijk licht af en het aandeel van Italië licht toe. Het aandeel van Nederland in de totale invoerwaarde van kaas door Duitsland schommelt de laatste jaren rond de $30 \%$.

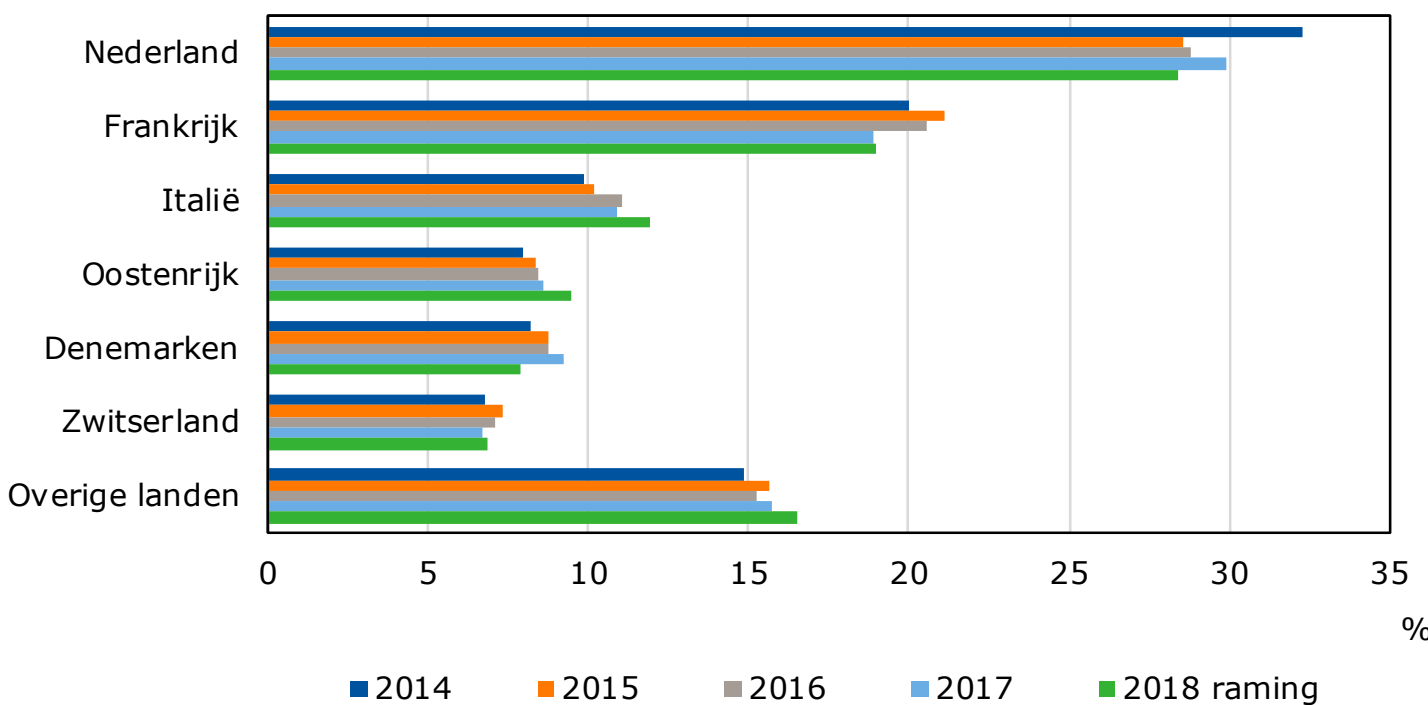

Figuur 3.24 Aandeel van de belangrijkste herkomstlanden in de Duitse import van kaas. Bron: Comext/Eurostat tot en met september 2018, raming oktober-december 2018 door WUR en CBS. 


\subsection{Duitsland belangrijke handelspartner voor import en export van varkensvlees}

De Nederlandse varkensvleesindustrie exporteert in 2018 voor ruim 1,8 miljard euro aan varkensvlees. Volgens de ramingen gaat hiervan 14\% (252 miljoen euro) naar Duitsland en 58\% (1 miljard euro) naar de overige EU-landen. Daarnaast gaat ruim een kwart van de exportwaarde naar bestemmingen buiten de EU (figuur 3.25). Tegenover deze export staat een import van 477 miljoen euro, waarvan 60\% (285 miljoen euro) uit Duitsland.

Duitsland is daarmee voor Nederland het belangrijkste handelsland van varkensvlees, resulterend in een nettohandelsbalans van -33 miljoen euro. Duitsland is voor Nederland ook een belangrijke bestemming van levende varkens (biggen en slachtvarkens), waarvan de waarde in 2017 circa 800 miljoen euro bedroeg (CBS). In 2018 zal de waarde van de export van levende dieren naar Duitsland lager zijn door gedaalde marktprijzen en minder uitgevoerde vleesvarkens.

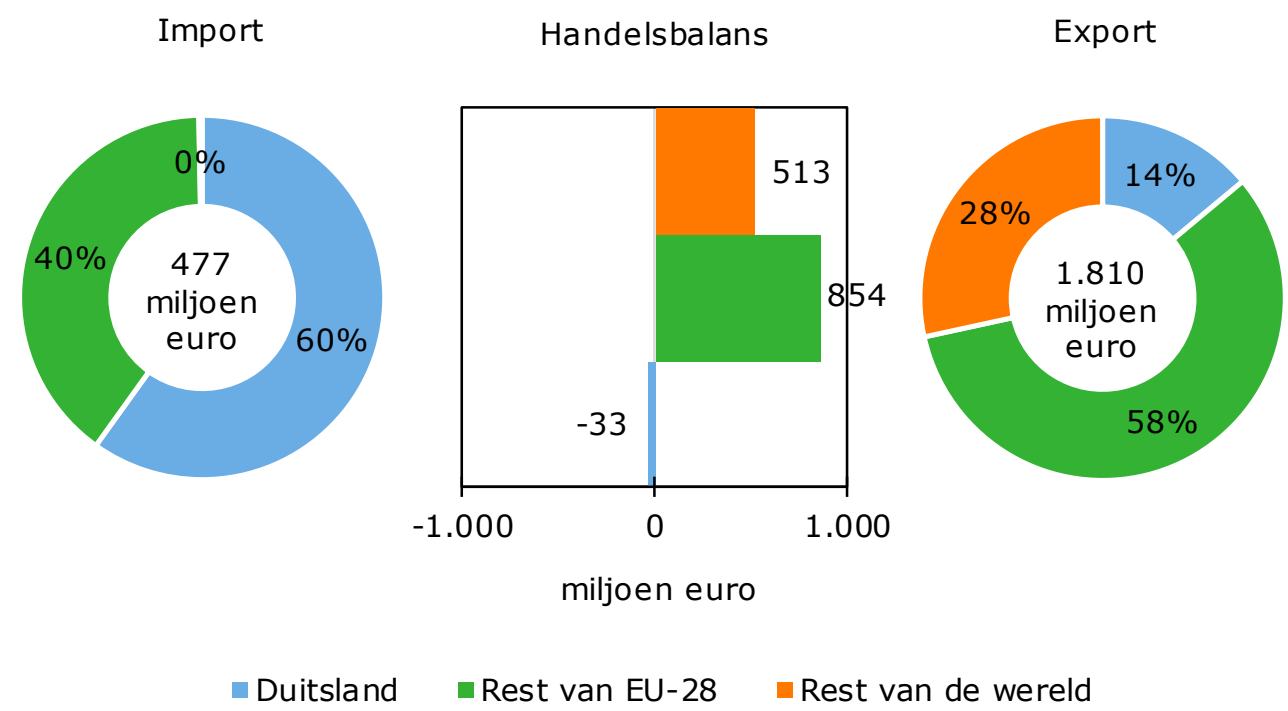

Figuur 3.25 Import en export van varkensvlees in 2018 naar regio.

Bron: CBS tot en met oktober 2018, raming november - december 2018 door WUR en CBS.

Het ingevoerde varkensvlees bestaat voor een groot deel uit Nederlandse varkens die eerst levend zijn vervoerd naar en vervolgens zijn verwerkt in Duitse slachterijen. Daaronder bevinden zich ook varkens die volgens het Nederlandse kwaliteitsprogramma 'Varkens van Morgen' en het Beter Leven keurmerk zijn geproduceerd en naar de Nederlandse supermarkten gaan. Dat deze varkens in Duitsland geslacht en verwerkt worden, hangt samen met de nabijheid (meerdere slachthuizen op vergelijkbare reisafstand als binnen Nederland) en de hoge efficiëntie van sommige Duitse slachthuizen, die daardoor concurrerende inkoopprijzen voor vleesvarkens kunnen betalen.

\subsubsection{Exportwaarde varkensvlees stagneert}

De totale exportwaarde van varkensvlees vanuit Nederland stagneert, na jarenlange stijgingen. De exportwaarde is gestegen van circa 1,5 miljard euro in 2010 tot ruim 30\% hoger: 1,9 miljard euro in 2017. Maar in 2018 daalt de exportwaarde door lagere prijzen van vleesvarkens en vooral biggen (figuur 3.26). 


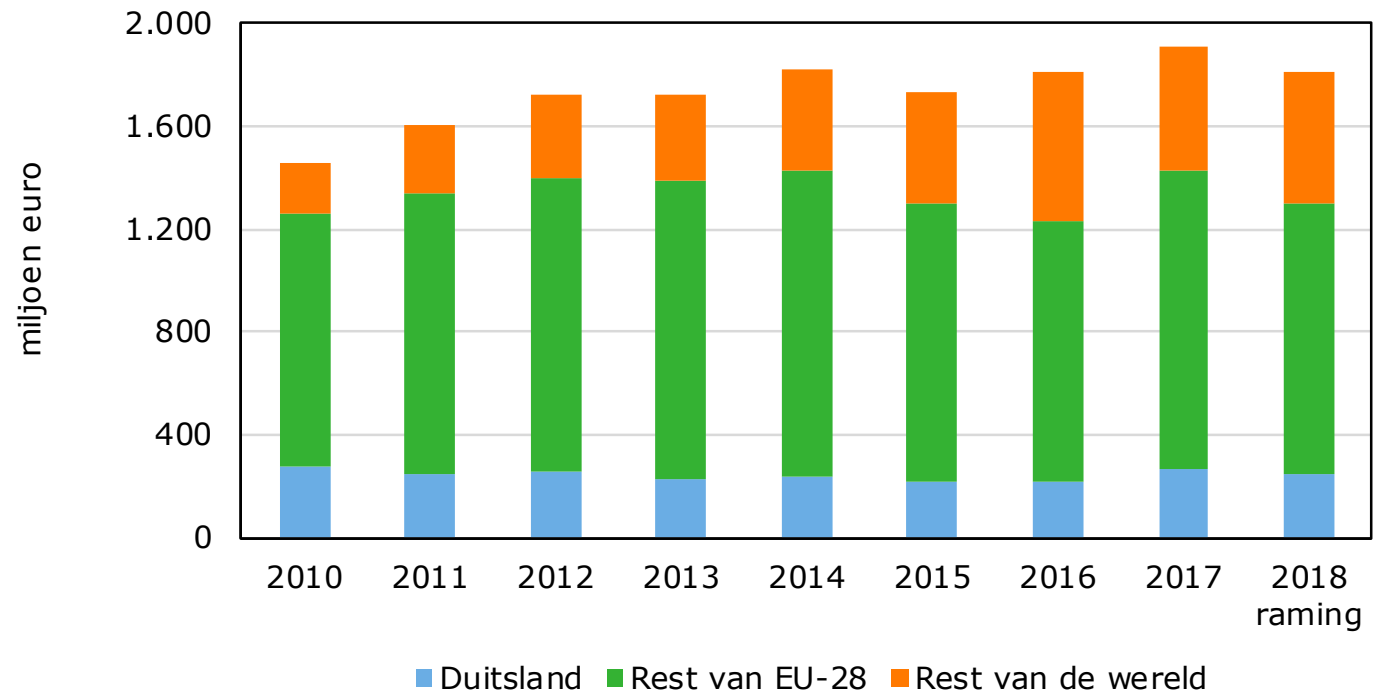

Figuur 3.26 Nederlandse export van varkensvlees.

Bron: CBS tot en met oktober 2018, raming november - december 2018 door WUR en CBS.

De afzet naar niet-Europese bestemmingen is tussen 2010 en 2016 aanzienlijk gestegen, van 196 miljoen euro tot 585 miljoen euro in 2016, vooral door de sterke toename van de afzet naar China. In 2017 is die afzet naar niet-Europese bestemmingen echter met $18 \%$ gedaald, naar 482 miljoen euro, vooral door de teruglopende afzet naar China en Japan. Voor 2018 wordt de totale afzet naar niet-Europese bestemmingen iets hoger geraamd, op 514 miljoen euro. De export naar China is opnieuw lager, maar dat wordt gecompenseerd door de hogere afzet naar andere Aziatische bestemmingen, zoals Japan en Zuid-Korea.

De afzet van varkensvlees naar niet-Europese bestemmingen groeit, terwijl de afzet naar EU-landen $9 \%$ lager is dan in 2017. Vooral de export naar Italië, het Verenigd Koninkrijk en Griekenland is lager geraamd dan in 2017. De exportwaarde naar Duitsland daalt iets minder (5\%), naar 252 miljoen euro in 2018. Die waarde ligt iets boven het meerjarig gemiddelde van 2010-2017.

De export van levende vleesvarkens is afgenomen. Daar staat tegenover dat het aantal binnenlandse slachtingen is toegenomen. De binnenlandse slachtcapaciteit is voldoende om meer vleesvarkens te verwerken. Bovendien liggen de uitbetaalde prijzen voor slachtvarkens in Nederland en Duitsland dichter bij elkaar dan tot enkele jaren geleden, waardoor het minder aantrekkelijk is om varkens naar Duitsland uit te voeren.

\section{Uitvoerwaarde naar Duitsland in $\mathbf{2 0 1 8}$ iets lager}

Italië is in waarde gemeten de grootste afnemer van varkensvlees uit Nederland, gevolgd door Duitsland en Griekenland (figuur 3.27). De totale afzet van varkensvlees naar Duitsland in 2018 is geraamd op 252 miljoen euro; 5\% minder dan in 2017. China is twee plaatsen teruggevallen, van de vierde naar de zesde exportbestemming in 2018, doordat de exportwaarde $30 \%$ is gedaald. De totale exportwaarde naar de vijf grootste afzetlanden bedraagt bijna 1 miljard euro, oftewel 53\% van de totale exportwaarde vanuit Nederland. 


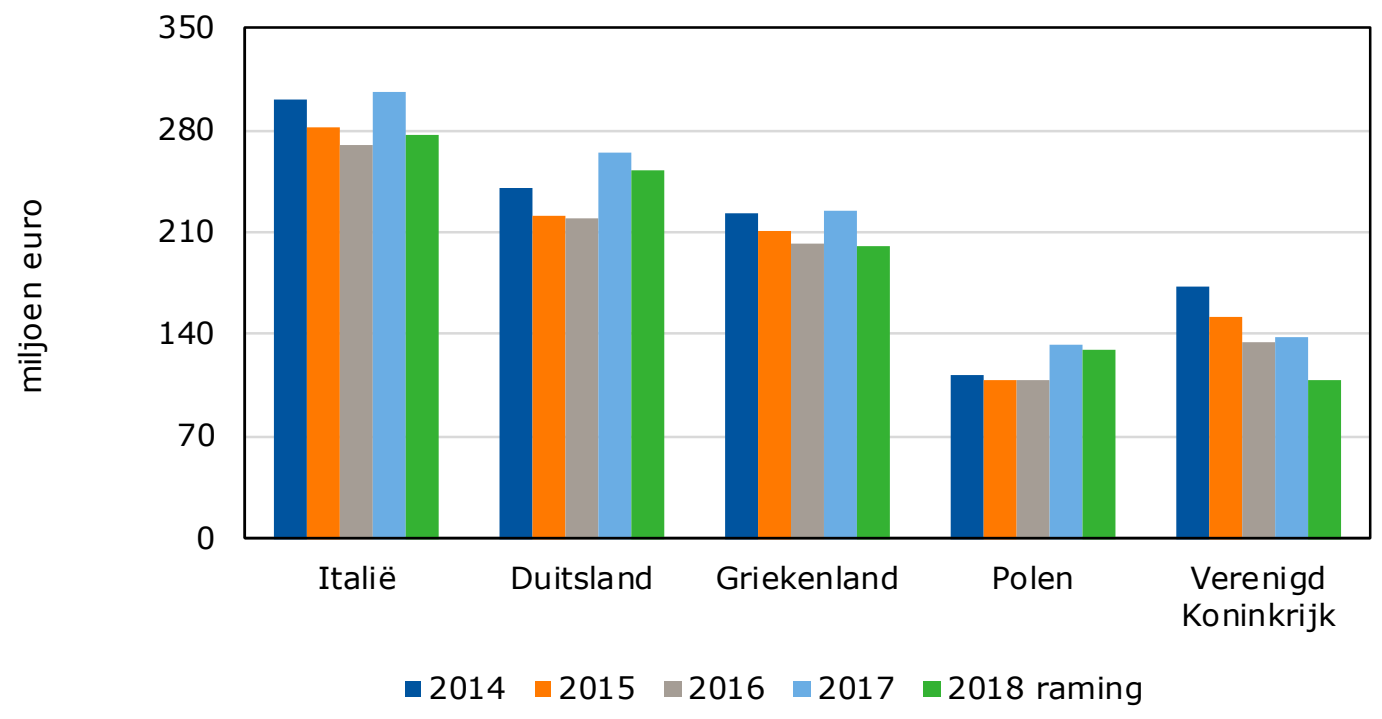

Figuur 3.27 Belangrijkste bestemmingen in de Nederlandse export van varkensvlees. Bron: CBS tot en met oktober 2018, raming november - december 2018 door WUR en CBS.

Nederland is een handelsland met veel uitvoer, maar ook invoer van varkensvlees. Een deel van de export is zogenaamde wederuitvoer: $8 \%$ van de export heeft betrekking op geïmporteerd varkensvlees dat na eventuele bewerking weer wordt geëxporteerd. Verreweg het grootste deel (92\%) van de totale uitvoer betreft in Nederland geproduceerd varkensvlees. Voor de export naar Duitsland geldt een vergelijkbaar hoog percentage.

\subsubsection{Importaandeel op Duitse markt in 2018 gestegen}

Duitsland importeerde in 2018 naar schatting voor 1,4 miljard euro aan varkensvlees. De belangrijkste leveranciers zijn Denemarken en België, op ruime afstand gevolgd door Nederland met een totale waarde van 229 miljoen euro. Nederland heeft daarmee een importaandeel in de totale varkensvleesimport in Duitsland van 16\%. Dat is net iets hoger dan in 2017, en hoger dan in de meeste voorgaande jaren. Het importaandeel van met name Denemarken op de Duitse markt is wel iets gestegen.

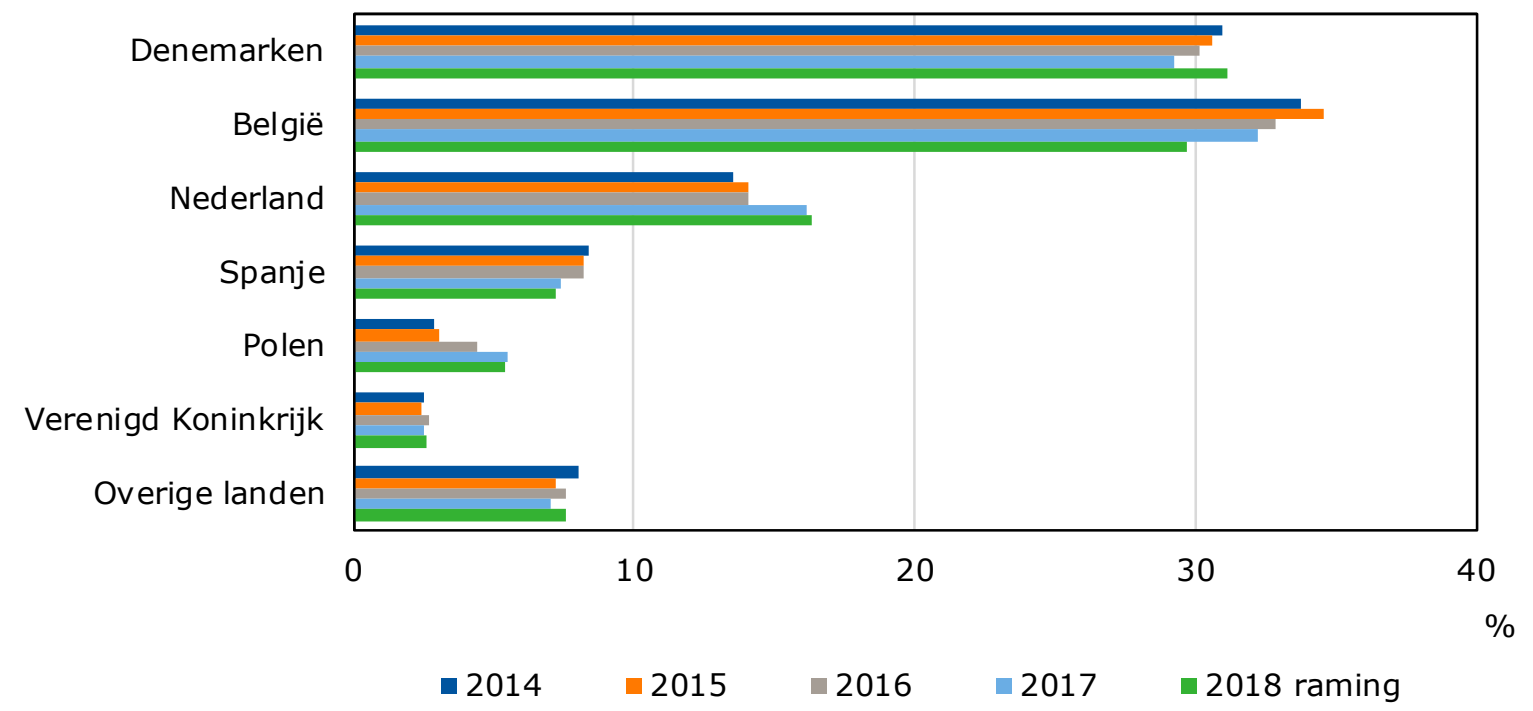

Figuur 3.28 Aandeel van de belangrijkste herkomstlanden in de Duitse import van varkensvlees. Bron: Comext/Eurostat tot en met september 2018, raming oktober-december 2018 door WUR en CBS. 


\subsection{Duitsland blijft belangrijkste afzetmarkt voor Nederlandse eieren}

De ramingen voor 2018 geven in vergelijking met 2017 een hogere waarde van export consumptieeieren. De invoerwaarde is in 2018 ook gestegen. Het resultaat is een overschot op de handelsbalans van 274 miljoen euro. Volgens deze raming is het overschot 15 miljoen euro hoger dan in 2017. Figuur 3.29 laat zien dat vooral het handelsoverschot met Duitsland dit resultaat verklaart. In 2018 wordt een overschot met Duitsland verwacht van 313 miljoen euro. De cijfers van zowel 2017 als 2018 zijn sterk beïnvloed voor de fipronil-affaire, die in de tweede helft van 2017 en de eerste maanden van 2018 leidde tot hoge eierprijzen.

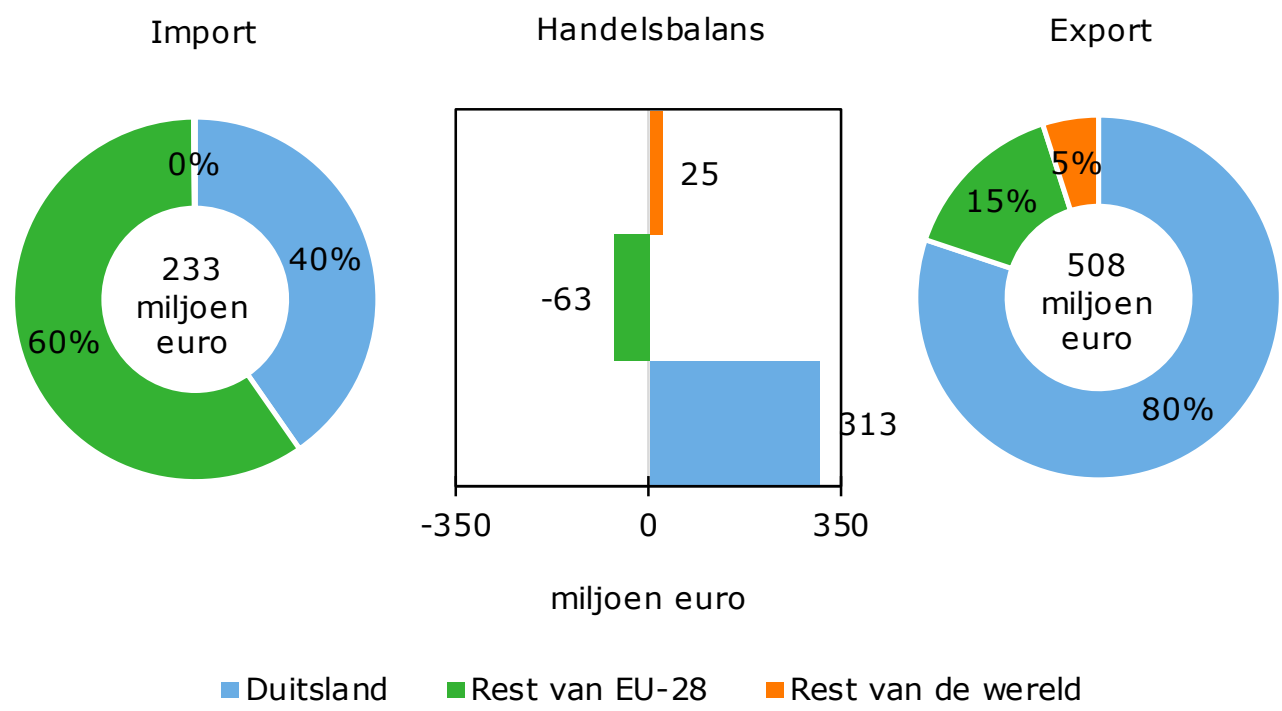

Figuur 3.29 Import en export van consumptie-eieren in 2018 naar regio. Bron: CBS tot en met oktober 2018, raming november - december 2018 door WUR en CBS.

\subsubsection{Toename warde van export naar Duitsland}

Voor de Nederlandse legpluimveesector is Duitsland een zeer belangrijke exportbestemming. Van de in Nederland geproduceerde eieren gaat circa de helft naar Duitsland. Het merendeel is export als consumptie-ei, maar ook veel eieren gaan in de vorm van eiproduct naar onze Oosterburen. De totale waarde van de export van consumptie-eieren wordt voor 2018 geraamd op 407 miljoen euro.

Van de totale export van consumptie-eieren gaat in 2018 bijna 95\% naar EU-landen. Van de EUlanden is Duitsland veruit de belangrijkste bestemming. Het aandeel Duitsland in de EU-export wordt voor 2018 geschat op 84\%. In 2017 was dit aandeel $83 \%$.

Nederland had in de tweede helft van 2017 te maken met de fipronil-affaire. In de periode vanaf augustus 2017 was de eierproductie lager, doordat eieren vernietigd werden en door het vroegtijdig afvoeren van leghennen. Door de lagere productie stegen de eierprijzen naar een hoog niveau. De periode van hoge prijzen liep door tot en met april 2018. Vooral voor scharreleieren en eieren van hennen met vrije uitloop waren de marktprijzen gedurende een langere periode erg hoog. Dit leidde tot hoge exportwaarden van consumptie-eieren.

Naast naar Duitsland is er afzet naar België, Zwitserland, Frankrijk en Oostenrijk. De waarde van deze export is fors lager dan de export naar Duitsland. De raming voor 2018 voor de waarde van de export naar België is 54, Zwitserland 18, Frankrijk 7 en Oostenrijk 5 miljoen euro. In figuur 3.31 is te zien dat de waarde in 2018 voor Duitsland en België gestegen is. Voor de andere landen is dit niet het geval. 
Nederland is een handelsland met veel uitvoer, maar ook veel invoer van consumptie-eieren. Een deel van de exportwaarde is zogenaamde wederuitvoer: $26 \%$ van de export heeft betrekking op geïmporteerde consumptie-eieren die na een bewerking (bijvoorbeeld sorteren en verpakken) weer geëxporteerd worden. Het merendeel, namelijk $74 \%$ van de waarde, bestaat uit in Nederland geproduceerde eieren die worden geëxporteerd. De genoemde percentages gelden voor zowel de totale export als de export naar Duitsland.

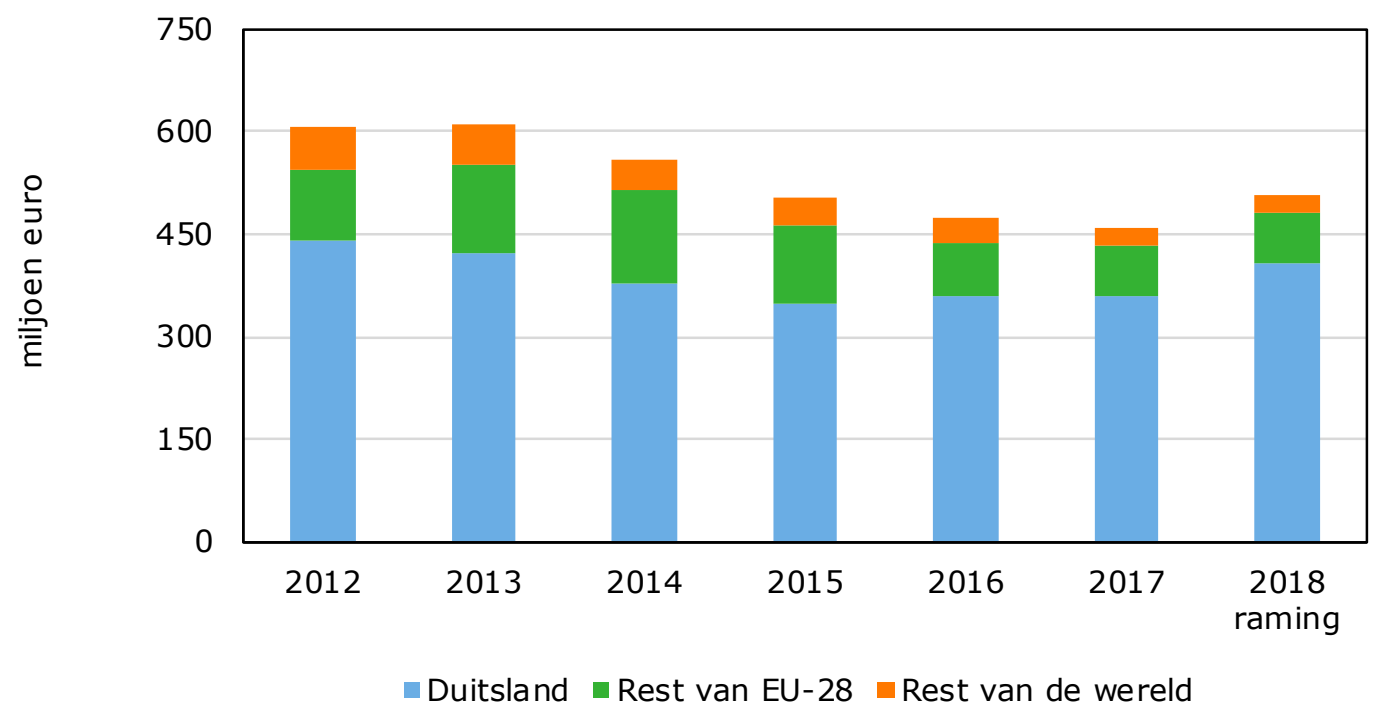

Figuur 3.30 Nederlandse export van consumptie-eieren.

Bron: CBS tot en met oktober 2018, raming november - december 2018 door WUR en CBS.

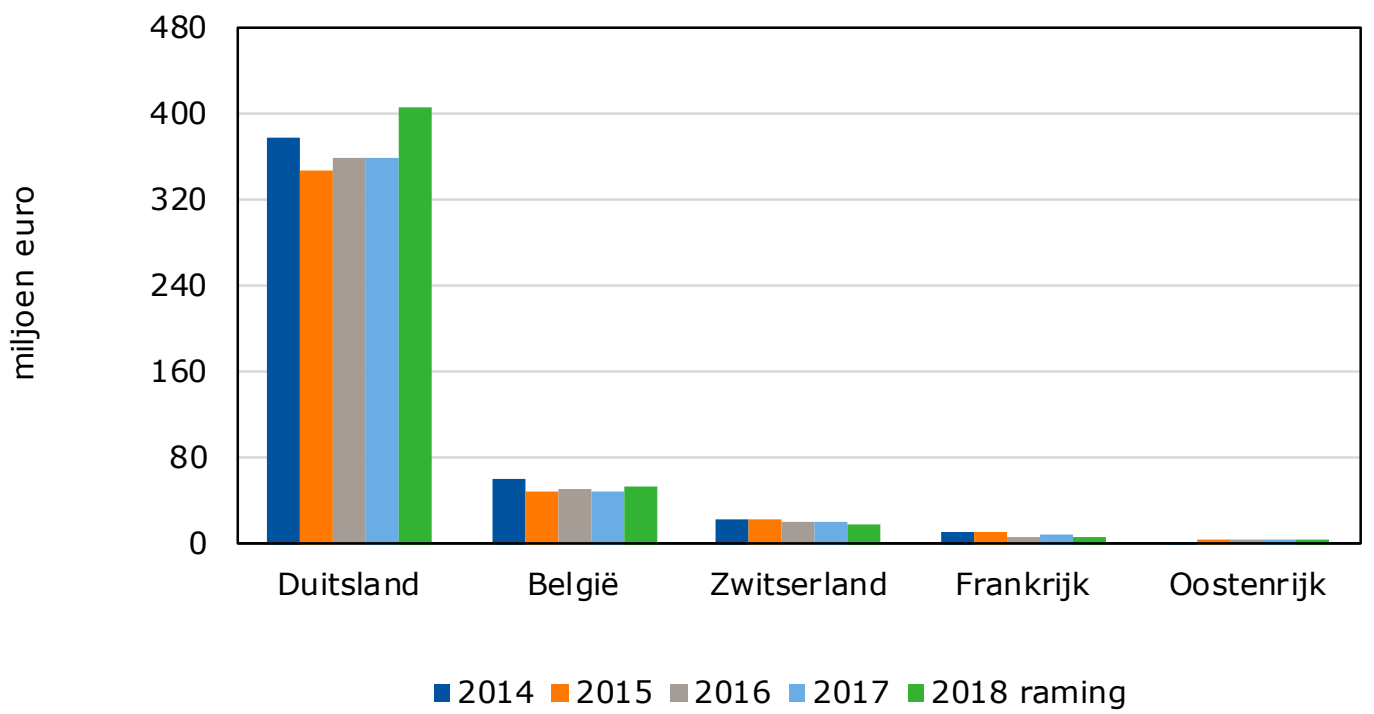

Figuur 3.31 Belangrijkste bestemmingen in de Nederlandse export van consumptie-eieren. Bron: CBS tot en met oktober 2018, raming november - december 2018 door WUR en CBS.

\subsubsection{Marktaandeel Nederland op Duitse markt blijft circa $80 \%$}

Op de Duitse markt is Nederland veruit de belangrijkste speler. In 2018 is het aandeel van Nederland in de totale Duitse invoer $80 \%$. De belangrijkste concurrenten zijn Polen en, in mindere mate, België. De aandelen van Nederland, maar ook van Polen en België in de Duitse invoer, zijn de laatste jaren redelijk stabiel. Er zijn tussen 2014 en 2018 geen noemenswaardige verschuivingen opgetreden. In figuur 3.32 worden de details gegeven. 


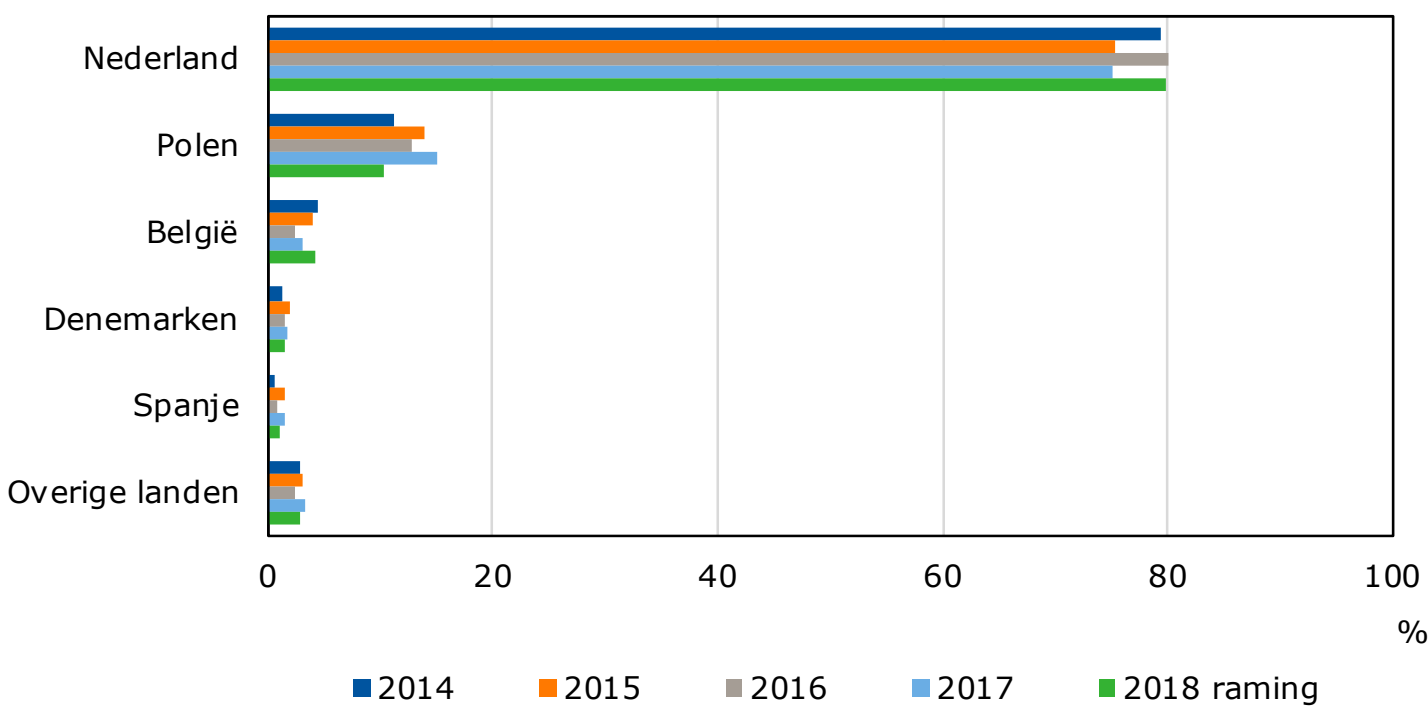

Figuur 3.32 Aandeel van de belangrijkste herkomstlanden in de Duitse import van consumptieeieren.

Bron: Comext/Eurostat tot en met september 2018, raming oktober-december 2018 door WUR en CBS.

\section{Hogere eierprijzen in 2017 en 2018}

In de tweede helft van 2017 en de eerste maanden van 2018 waren de prijzen van eieren relatief hoog als gevolg van de fipronil-affaire. De gemiddelde opbrengstprijs voor leghennenhouderijen die witte scharreleieren produceren was in 2015, 2016, 2017 en 2018 (tot en met oktober) respectievelijk $1,04,0,92,1,21$ en 1,17 euro per kilogram. Hierdoor nam de exportwaarde in 2017 en 2018 toe, wat ook naar voren komt in figuur 3.30 en 3.31. Verwacht kan worden dat in 2019 de waarde weer zal dalen als de export weer plaatsvindt tegen een meer gemiddeld prijsniveau.

Duidelijk is dat er in de Duitse media veel negatieve aandacht is geweest voor Nederlandse eieren. Dit effect zal nog langere tijd doorwerken en is van invloed op het imago van het Nederlandse ei op de Duitse markt. Daarbij komt dat de Duitse consument in toenemende mate een voorkeur heeft voor Duitse eieren. Enkele supermarktketens hebben recent aangekondigd over enkele jaren alleen nog maar Duitse eieren te willen verkopen. Dit zal extra druk zetten op exportmogelijkheden voor de Nederlandse eierensector. De enige keuze voor Nederland is het leveren van een kwalitatief hoogwaardig ei dat voldoet aan alle marktwensen vanuit Duitsland. De Nederlandse sector doet dit al door het houden van leghennen met onbehandelde snavels en door gebruik te maken van legvoer dat vrij is van genetisch gemodificeerde organismen (non-GMO-voer). De verwachting is dat de Duitse supermarkten de komende jaren met verdergaande eisen zullen komen om het dierenwelzijnsniveau voor leghennen te verhogen en de productkwaliteit nog verder te verbeteren. Voor de Nederland eierensector is het zaak hierop alert te reageren en een voorsprong te behouden op de concurrenten in Polen en België.

\subsection{Nederland bij uitstek bloemenbollenhandelsland}

De Nederlandse handel in bloembollen is wereldwijd georiënteerd en de bloembollen worden naar alle uithoeken van de wereld geëxporteerd. De exportwaarde inclusief wederuitvoer bedraagt in 2018 naar verwachting 765 miljoen euro. Dit is een daling van ruim $5 \%$ ten opzichte van 2017 , die voor een groot deel zal zijn veroorzaakt door de lagere bloembollenproductie in Nederland als gevolg van de hete en droge zomer. De Verenigde Staten blijven de belangrijkste afnemer van de Nederlandse bloembollen, waarbij het aandeel in de totale export in de periode 2014-2018 is gestegen van 12 naar $15 \%$. China is het Verenigd Koninkrijk op de ranglijst gepasseerd en bezet nu de tweede plek, met 
een aandeel van $11 \%$ in 2018. De import is met een verwachte waarde van 41 miljoen euro in 2018 beperkt van omvang en vrijwel gelijk aan die in 2017.

Het overschot op de handelsbalans bedraagt in 2018 naar verwachting 724 miljoen euro, waarvan $38 \%$ wordt gerealiseerd binnen de EU en $62 \%$ daarbuiten.

Import

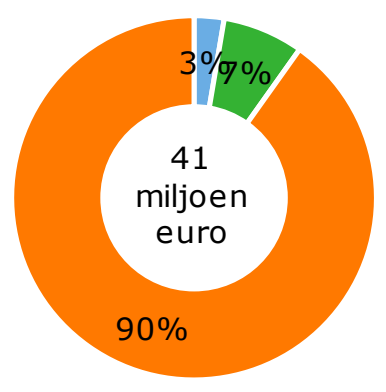

Handelsbalans

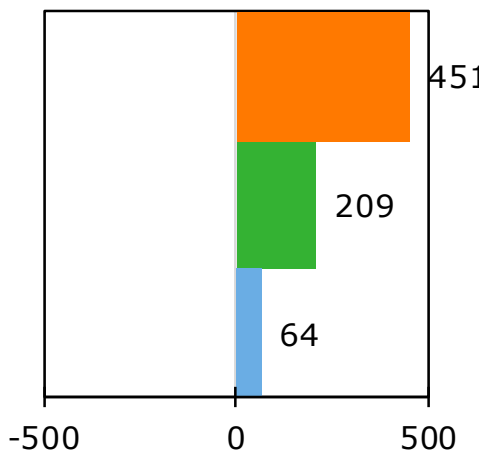

miljoen euro
Export

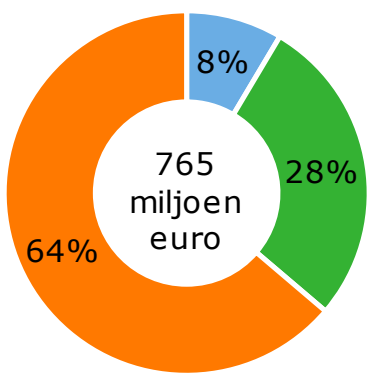

Duitsland $\quad$ Rest van EU-28 $\quad$ Rest van de wereld

Figuur 3.33 Import en export van bloembollen in 2018 naar regio.

Bron: CBS tot en met oktober 2018, raming november - december 2018 door WUR en CBS.

\subsubsection{Verenigde Staten en China belangrijkste exportbestemmingen}

Net als voorgaande jaren wordt ongeveer 35\% van de bloembollen afgezet binnen de EU en $65 \%$ daarbuiten. In vergelijking met andere agrarische producten is het aandeel dat buiten de EU-landen wordt afgezet zeer groot. De import is relatief gering en er worden meer bollen van buiten de EU geïmporteerd (90\%) dan van binnen de EU (10\%). Dit heeft te maken met het feit dat op het zuidelijk halfrond de teeltseizoenen tegengesteld zijn en deze bollen geschikt zijn voor de veredeling en als uitgangsmateriaal voor exclusieve bolbloemen in Nederland. Het betreft dan ook veelal bloembollen die door Nederlandse bedrijven elders in de wereld worden geteeld om van deze voordelen te profiteren. Ondanks de uitbreiding van het areaal in Nederland kostte het in 2018 door een lagere productie per hectare als gevolg van de hete en droge zomer moeite om de vraag vanuit de markt op een goede manier in te vullen, resulterend in sterk stijgende prijzen in de vrije verkoop. De marktvraag werd gestimuleerd door de goede resultaten in de Nederlandse broeierij van bolbloemen in het afgelopen seizoen.

De Verenigde Staten blijven de belangrijkste afzetmarkt voor Nederlandse bloembollen, waarbij het aandeel in de totale export in de periode $2014-2018$ is gestegen van $12 \%$ naar $15 \%$. Het Verenigde Koninkrijk heeft mede door de achterblijvende economische groei en de daling van het Britse pond de tweede plek verloren aan China, dat in 2018 een aandeel heeft van 12\%. Op deze ranglijst bezetten het Verenigd Koninkrijk en Duitsland momenteel de plaatsen drie en vier, met een aandeel van ongeveer $9 \%$. In 2018 bedraagt de waarde van de export van bloembollen naar onze oosterburen naar schatting 65 miljoen euro.

Door de grote geografische spreiding van de Nederlandse export over veel landen binnen en buiten de EU beschikt de branche over een goed mechanisme om tegenvallende marktontwikkelingen of mogelijke incidenten op individuele markten het hoofd te bieden. 


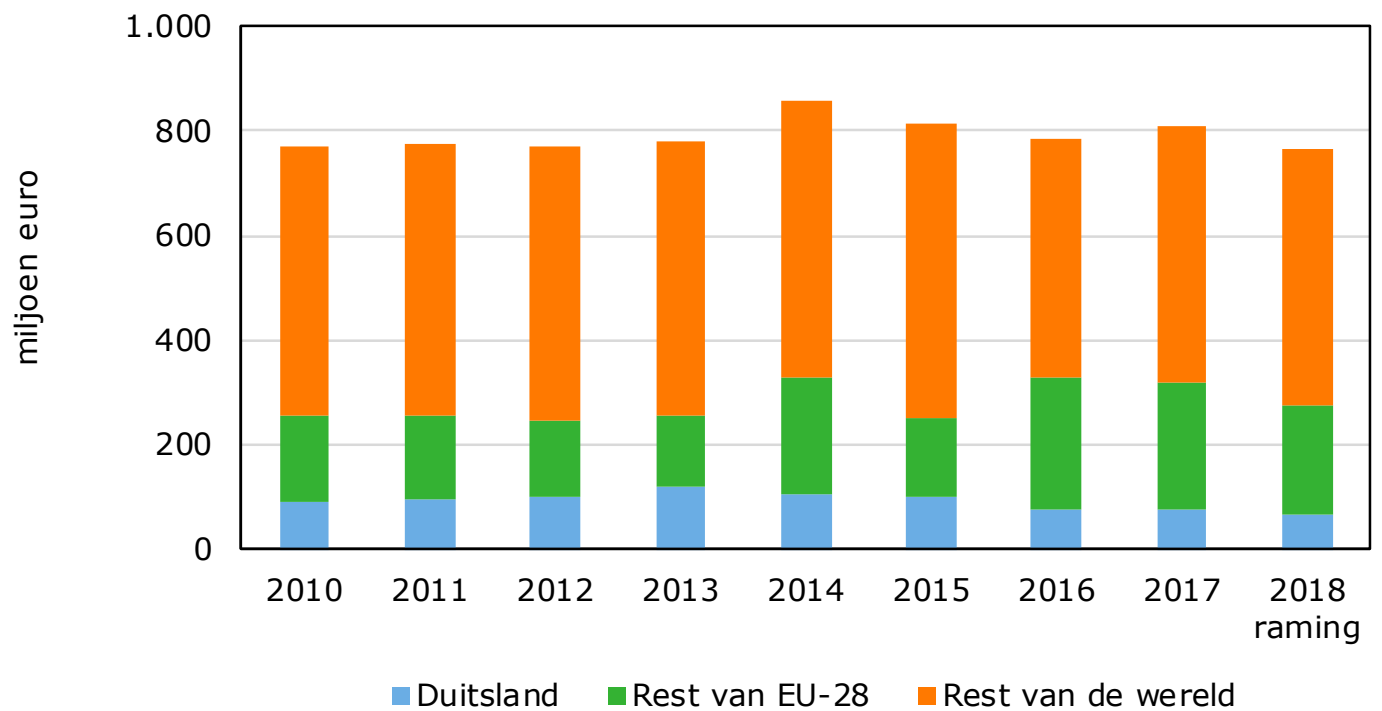

Figuur 3.34 Nederlandse export van bloembollen.

Bron: CBS tot en met oktober 2018, raming november - december 2018 door WUR en CBS.

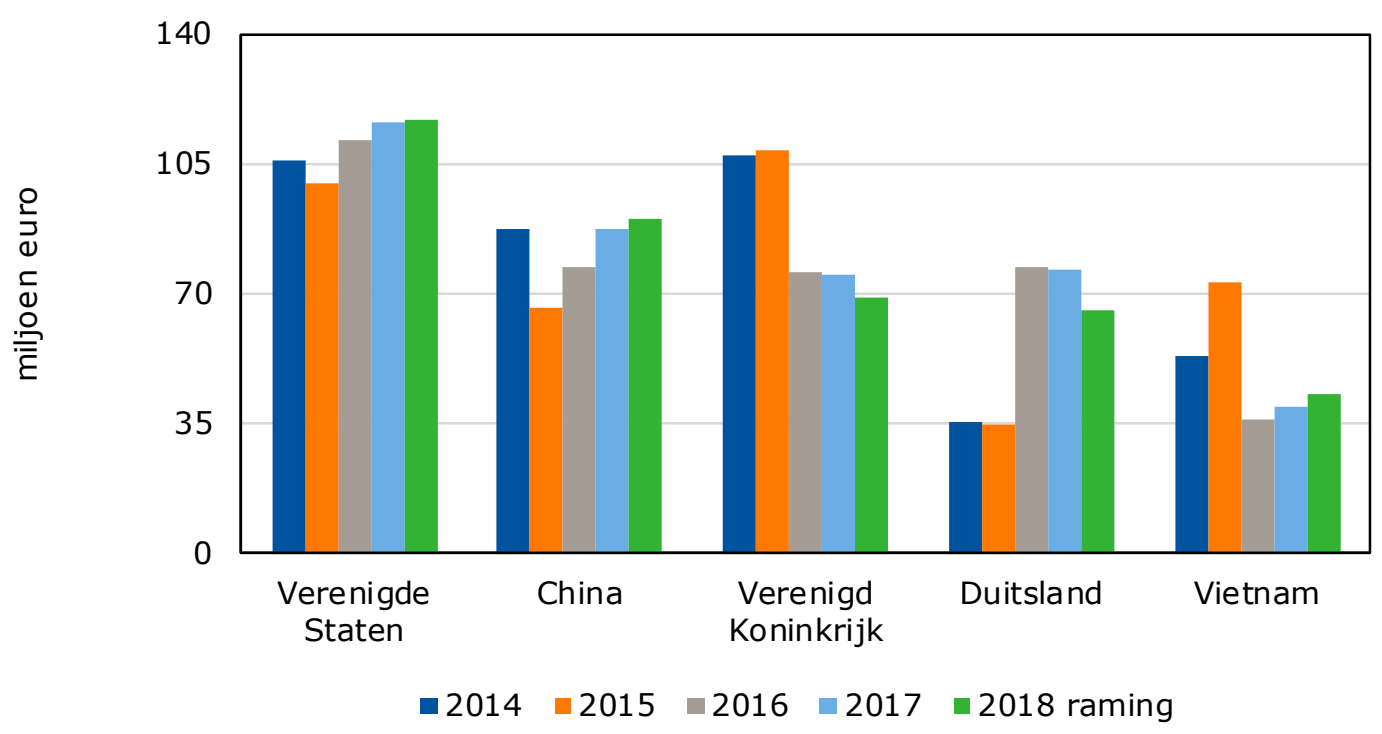

Figuur 3.35 Belangrijkste bestemmingen in de Nederlandse export van bloembollen.

Bron: CBS tot en met oktober 2018, raming november - december 2018 door WUR en CBS.

\subsubsection{Import van bloembollen in Duitsland gedomineerd door Nederland}

De import van bloembollen op de Duitse markt wordt, met een aandeel van 99\%, gedomineerd door Nederland. De overige landen spelen geen enkele rol van betekenis. 


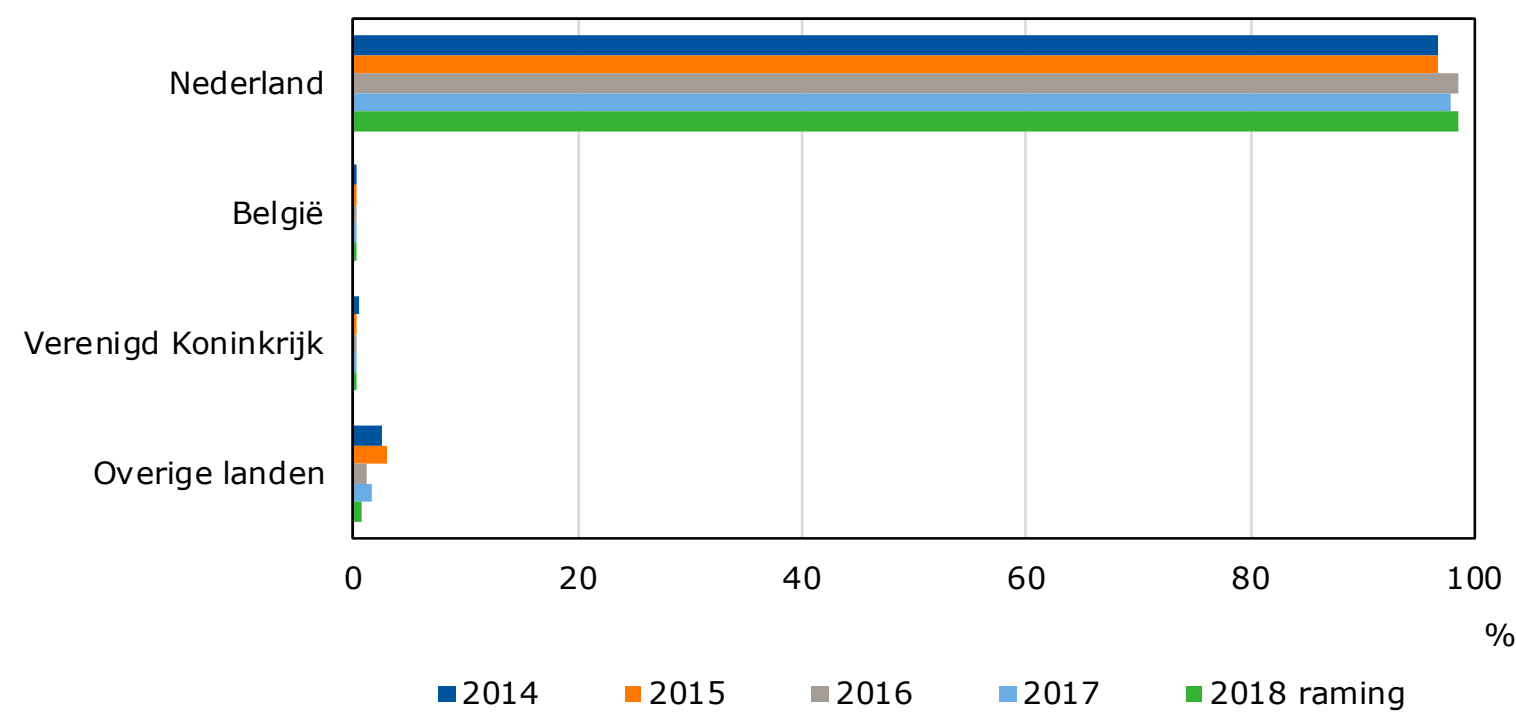

Figuur 3.36 Aandeel van de belangrijkste herkomstlanden in de Duitse import van bloembollen. Bron: Comext/Eurostat tot en met september 2018, raming oktober-december 2018 door WUR en CBS.

\subsection{Handelsbalansoverschot van landbouwgerelateerde goederen toegenomen}

Het handelsbalansoverschot van landbouwgerelateerde goederen is in 2018 toegenomen naar 5 miljard euro, door een hogere exportwaarde (9,2 miljard euro) bij een gelijkblijvende importwaarde (4,2 miljard euro) vergeleken met 2017 (zie figuur 3.37). De import en export naar Duitsland zijn min of meer gelijk aan elkaar. Het handelsbalansoverschot werd vooral gerealiseerd met landen buiten de EU. De vier belangrijkste geëxporteerde landbouwgerelateerde goederen zijn landbouwmachines, machines voor de voedingsmiddelenindustrie, meststoffen en kasmaterialen, welke samen $80 \%$ van de totale export vormen. De Nederlandse export en import van landbouwgerelateerde goederen vindt grotendeels plaats binnen de Europese Unie, namelijk voor respectievelijk $58 \%$ en $81 \%$. Duitsland heeft een aandeel van $15 \%$ in de export en $27 \%$ in de import van landbouwgerelateerde goederen.

Import

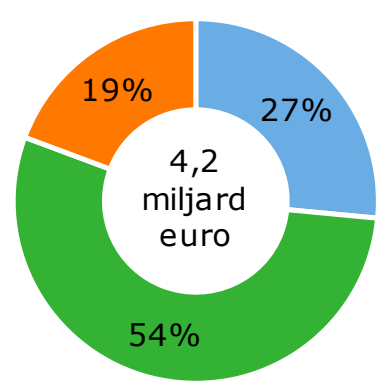

Handelsbalans

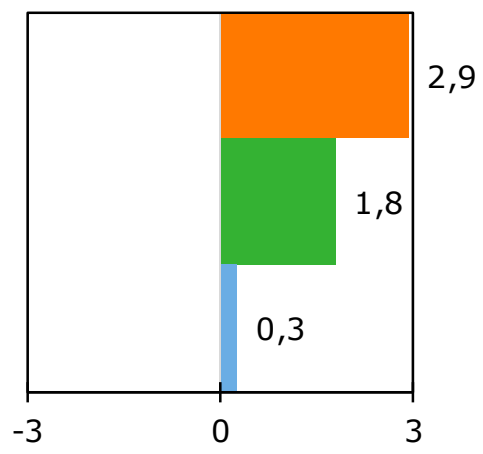

miljard euro
Export

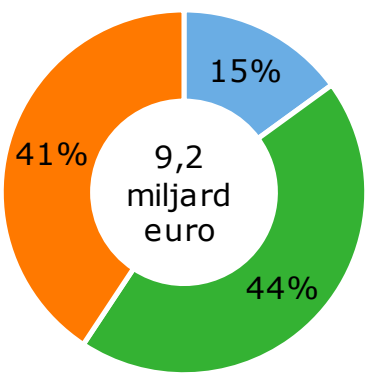

Figuur 3.37 Import en export van landbouwgerelateerde goederen in 2018 naar regio. Bron: CBS tot en met oktober 2018, raming november - december 2018 door WUR en CBS. 


\subsubsection{Export van landbouwgerelateerde goederen groeit gestaag}

De Nederlandse export van landbouwgerelateerde goederen is toegenomen van 8,9 miljard euro in 2017 naar 9,2 miljard euro in $2018(+3,2 \%)$. De toename is vooral te danken aan de toegenomen export naar de rest van de wereld ( $+0,3$ miljard euro), terwijl de export binnen Europa licht daalde (-0,02 miljard euro; zie figuur 3.38). De export van machines voor de voedingsmiddelenindustrie nam fors toe (+316 miljoen; $+19 \%)$. Grootste daler bij de landbouwgerelateerde export was de export van meststoffen (-120 miljoen euro; $-7 \%)$.

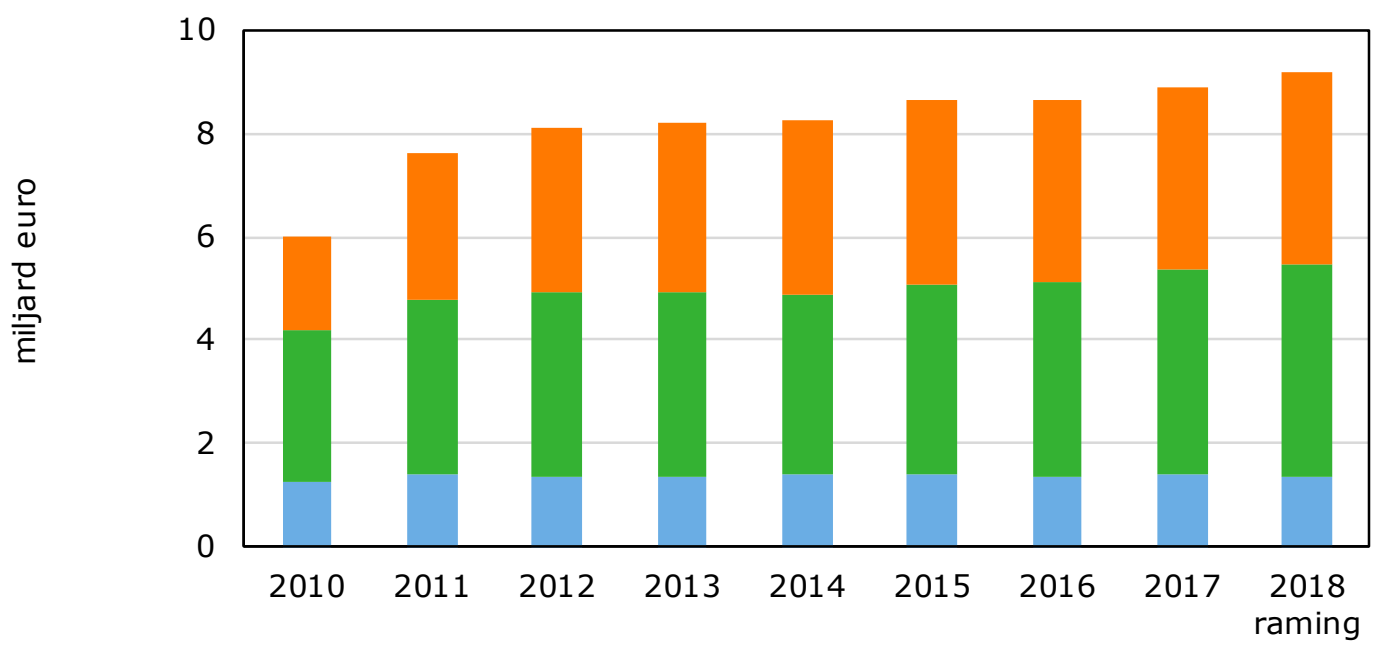

Duitsland $\quad$ Rest van EU-28 $\quad$ Rest van de wereld

Figuur 3.38 Nederlandse export van landbouwgerelateerde goederen.

Bron: CBS tot en met oktober 2018, raming november - december 2018 door WUR en CBS.

Duitsland is de belangrijkste exportbestemming voor landbouwgerelateerde goederen $(1,4$ miljard euro), gevolgd door België (0,9 miljard euro), Frankrijk (0,7 miljard euro) en het Verenigd Koninkrijk (0,6 miljard euro). Vanaf 2010 is de export van landbouwgerelateerde goederen met meer dan $50 \%$ toegenomen. Van de waarde aan alle Nederlandse geëxporteerde landbouwgerelateerde goederen binnen Europa is in 2018 circa 70\% van Nederlandse makelij. Voor de rest van de wereld is dit hoger, namelijk circa 75\%. Deze cijfers komen overeen met die van 2017 (zie paragraaf 4.3).

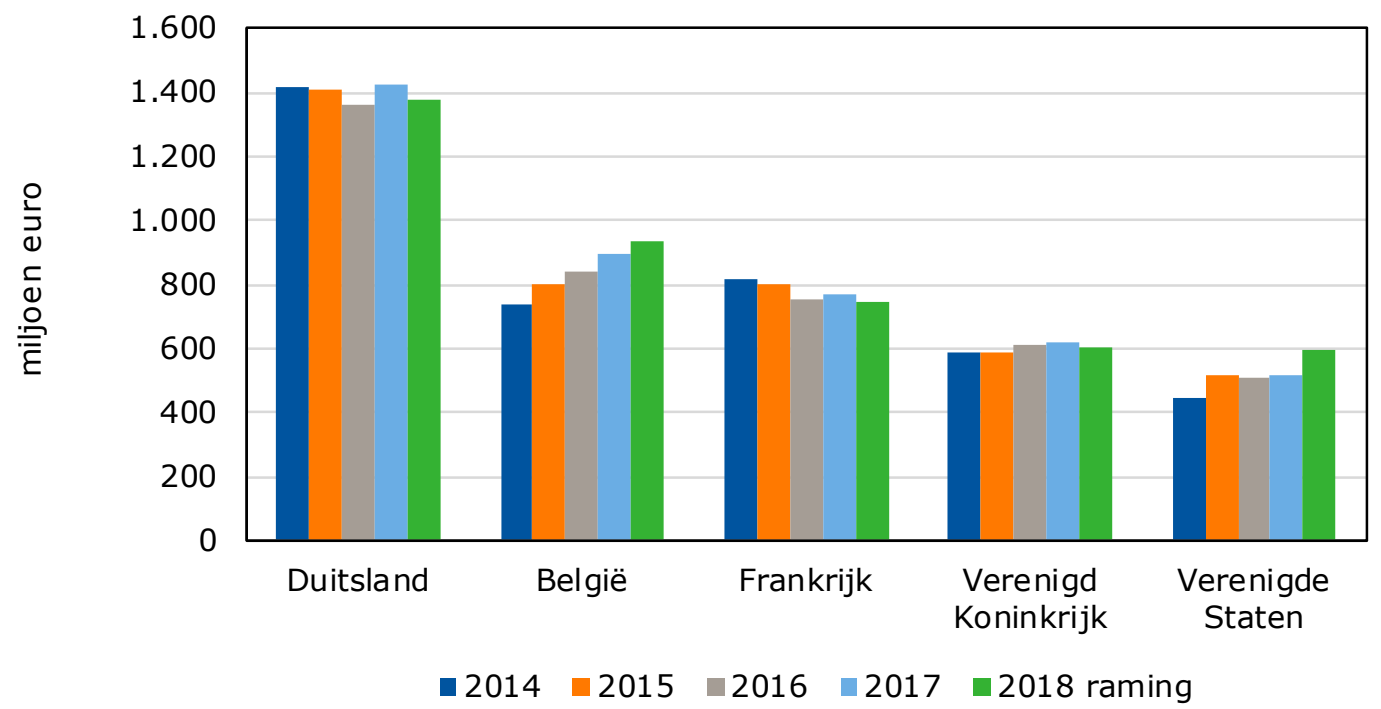

Figuur 3.39 Belangrijkste bestemmingen in de Nederlandse export van landbouwgerelateerde goederen.

Bron: CBS tot en met oktober 2018, raming november - december 2018 door WUR en CBS. 
De belangrijkste exportbestemming van landbouwgerelateerde goederen is Duitsland, dat goed is voor bijna 1,4 miljard euro in 2018. Andere belangrijke bestemmingen zijn België, Frankrijk, de Verenigde Staten en het Verenigd Koninkrijk. De exportwaarde naar Duitsland laat, op 2017 na, al enkele jaren een lichte daling zien. Naar België neemt de exportwaarde daarentegen gestaag toe.

Landbouwmachines en meststoffen zijn de belangrijkste (in waarde) geëxporteerde landbouwgerelateerde goederen naar bovengenoemde landen, waarbij naar Duitsland ook veel kasmaterialen worden geëxporteerd. De daling in exportwaarde naar Duitsland houdt vooral verband met de daling in de export van meststoffen en kasmaterialen. De exportwaarde van landbouwmachines nam daarentegen substantieel toe.

\subsubsection{Marktaandeel van Nederland in Duitsland afgenomen}

Het Nederlands aandeel in de Duitse import van landbouwgerelateerde goederen is van $14 \%$ in 2016 en 2017 gedaald naar 12\% in 2018 (zie figuur 3.40). Polen heeft in 2018 een vergelijkbaar marktaandeel als Nederland. De waarde van het marktaandeel van Nederland in Duitsland laat sinds 2015 een daling zien. Overigens neemt ook de totale waarde van door Duitsland geïmporteerde landbouwgerelateerde goederen sinds 2015 af ( 8 miljard euro in 2018 ten opzichte van 9,1 miljard euro in 2015).

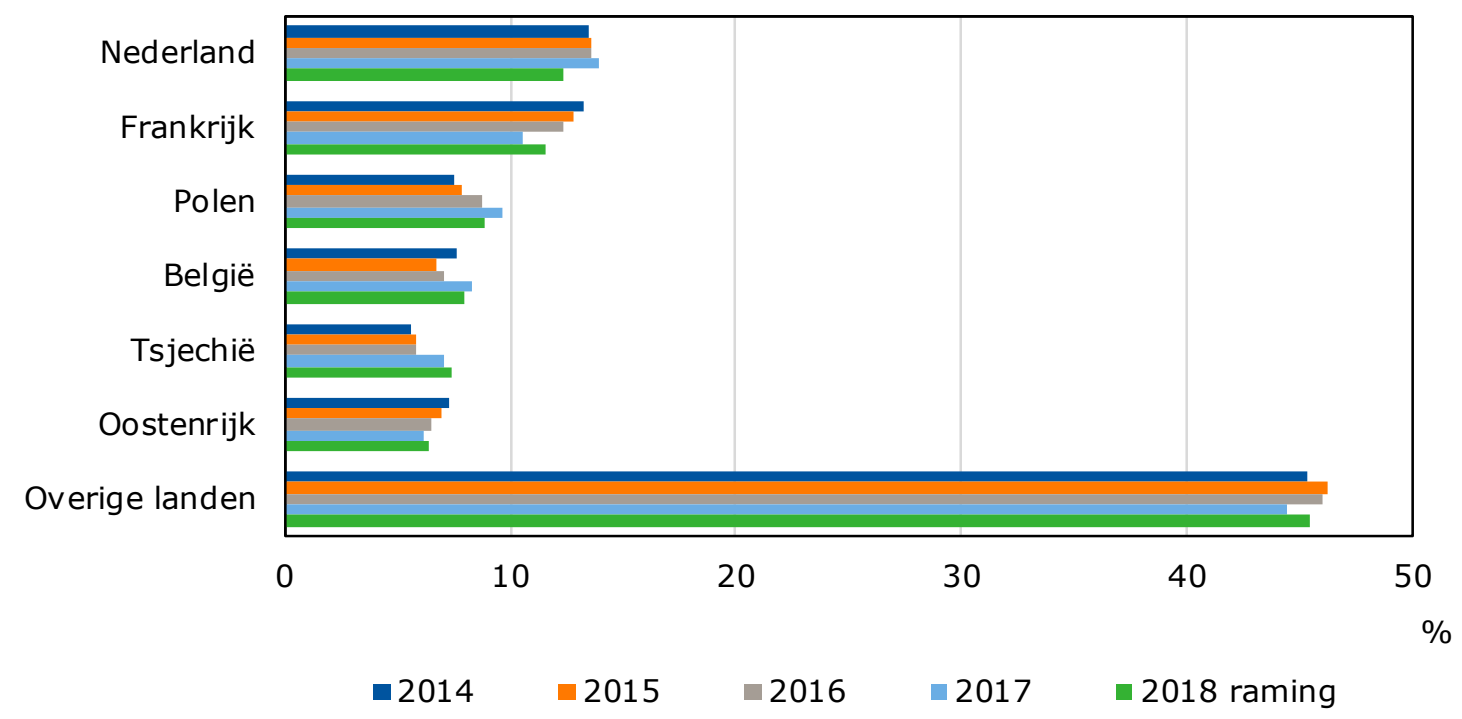

Figuur 3.40 Aandeel van de belangrijkste herkomstlanden in de Duitse import van landbouwgerelateerde goederen.

Bron: Comext/Eurostat tot en met september 2018, raming oktober-december 2018 door WUR en CBS. 


\section{$4 \quad$ Nederlandse export van landbouwgoederen in breder perspectief}

In dit hoofdstuk wordt nader ingegaan op de positie van de Nederlandse landbouwexport in de wereld. Vervolgens wordt verklaard of de gepresenteerde waardeontwikkelingen bij de Nederlandse in- en uitvoer vooral door prijsontwikkelingen of vooral door volumeontwikkelingen wordt veroorzaakt. Verder wordt beschreven welk deel van de landbouwexport van Nederlandse makelij is en in hoeverre het gaat om wederuitvoer van buitenlandse makelij. Tot slot is berekend wat de Nederlandse economie eigenlijk verdient aan de Nederlandse landbouwexport.

\subsection{Nederland behoudt exportpositie in wereld}

Ook in 2017 is Nederland de op één na grootste landbouwexporteur van de wereld. De Verenigde Staten blijven tevens de nummer 1 . Duitsland, Brazilië en China vullen de top vijf van belangrijkste exportlanden op landbouwgebied in 2017 aan.

De omvang van de wereldmarkt voor landbouwgoederen is in 2017 , volgens de meest recente cijfers uit de UN Comtrade-database, geraamd op 1.647 miljard dollar. Dit is 7\% hoger dan een jaar geleden, toen het niveau ongeveer 1.537 miljard dollar bedroeg. Zoals bij de UN Comtrade-database gebruikelijk is, zijn er niet voor elk land elk jaar data beschikbaar, omdat landen soms geen data aanleveren. Ook in 2017 was dit het geval. Voor alle landen waarvan cijfers ontbraken, is een aanname gemaakt om tot deze totaal schatting te komen (zie verder de dataverantwoording).

De Verenigde Staten exporteerden in 2017 voor ongeveer 163 miljard dollar aan landbouwgoederen. Dit is zo'n $10 \%$ van de wereldhandel in landbouwgoederen. Nederland is met 101 miljard dollar op afstand nummer twee. Daarna volgen dus Duitsland (94 miljard), Brazilië (83 miljard) en China (77 miljard). De top vijf is de laatste drie jaar niet veranderd. Alleen wisselden Brazilië en China in 2016 van positie, vooral door de toen tegenvallende prijzen voor oliezaden, die vooral door Brazilië worden geëxporteerd. Inmiddels is deze rangorde hersteld.

Een opvallend verschil tussen de landen is dat in deze top vijf Brazilië en Nederland netto-exporteurs zijn, terwijl de Verenigde Staten, Duitsland en vooral China meer importeren dan exporteren. Brazilië is zelfs de grootste netto-exporteur op landbouwgebied in de wereld, gevolgd door Argentinië en als derde Nederland. Thailand en Indonesië vullen deze top vijf van netto-exporteurs aan. China is juist de grootste netto-importeur van de wereld voor landbouwgoederen, gevolgd door Japan en het Verenigd Koninkrijk. Zuid-Korea, Hongkong en Saoedi-Arabië (schatting) liggen dicht bij elkaar als het om plek 5 gaat.

De exportwaarde groeide tussen 2016 en 2017 bij alle landen uit de top vijf, maar de exportwaarde van Brazilië groeide het sterkst, namelijk met $14 \%$. Ook in absolute zin was de groei in de top vijf voor dat land het grootst, gevolgd door Nederland (8\%). De groeipercentages van de VS en China lagen dicht bij elkaar (beide 3\%). De groei van Duitsland bedroeg 6\%. Maar in alle landen steeg ook de importwaarde. Vooral China had behoefte aan een grotere landbouwimport (+15\%). De Nederlandse import steeg ook sterk, namelijk met 10\%. De groei van de Verenigde Staten (6\%) en Duitsland (7\%) lag dicht bij elkaar, terwijl de import van landbouwgoederen door Brazilië slechts een bescheiden groei kende van $3 \%$.

Belangrijke exportmarkten voor de Verenigde Staten zijn Canada, China, Mexico, Japan en ZuidKorea. Ongeveer $17 \%$ van de exportwaarde van de Verenigde Staten gaat naar Canada. Dit aandeel is de laatste drie jaar licht dalend. In 2017 nam ook het aandeel van de export naar China af. Naar dit land werd vanuit de VS ook in absolute zin en als enige uit de top vijf minder geëxporteerd dan in 
2016. Of deze daling structureel is, moet nog blijken. De aandelen van Mexico, Japan en Zuid-Korea blijven min of meer stabiel. Samen is de top vijf van landen waar de VS naar exporteert goed voor $57 \%$ van de totale exportwaarde van de Verenigde Staten. De VS exporteren vooral oliezaden, granen, vlees en fruit. Met name de exportwaarde van vlees steeg, maar die van oliezaden daalde in 2016 en 2017.

De belangrijke exportmarkten voor Duitsland zijn Nederland (13\%), Frankrijk (8\%), Italië (8\%), Oostenrijk (6\%) en Polen (6\%). Deze aandelen waren de laatste drie jaar redelijk stabiel. De gezamenlijke top vijf waar Duitsland naar exporteert, is goed voor $41 \%$ van de totale landbouwexport. Dit is dus een stuk lager dan bij de Verenigde Staten en Nederland. Van de totale landbouwexport van Nederland gaat $60 \%$ naar de top vijf landen. Duitsland exporteert vooral zuivel, vlees, producten uit de meelindustrie en dranken.

Brazilië is voor de landbouwexport in grote mate afhankelijk van China. In 2017 was het aandeel dat China had in de totale landbouwexport van Brazilië 27\%. Op afstand zijn het de VS, Nederland, Japan en Hongkong die de top vijf compleet maken. Hiermee is Brazilië wel een land dat samen met de VS sterk globaal georiënteerd is als het gaat om haar belangrijkste exportbestemmingen. Samen hebben deze 5 landen een exportaandeel van een kleine 43\%. Met name oliezaden, vlees, suiker en suikerwerk, diervoeders en koffie en thee worden door Brazilië geëxporteerd. Vooral van oliehoudende zaden, maar ook van vlees en suiker en suikerwerk, steeg de exportwaarde in 2016 en 2017.

China zet zijn landbouwgoederen vooral af naar omliggende landen. De belangrijkste handelspartner van China, als het om de export van landbouwgoederen gaat, is Japan. Ruim $13 \%$ van de export gaat naar dat land. Een bijna even groot aandeel gaat naar Hongkong en nog eens ruim 10\% wordt afgezet in de Verenigde Staten. Zuid-Korea en Vietnam hebben beiden een aandeel van $6 \%$. Thailand is het laatste land uit de top vijf, met een aandeel van 4\%, en de export naar dit land neemt de laatste jaren wat af. De export van China naar Vietnam daarentegen stijgt gestaag. Samen zijn deze vijf landen in 2017 goed voor bijna 50\% van de exportwaarde van landbouwgoederen uit China. China exporteert vooral veel vis en groente. Ook wordt veel vlees, vis en groente eerst verwerkt voordat het wordt geëxporteerd. Fruit staat ook in de top vijf van exportproducten. Vooral van verwerkte producten steeg de exportwaarde tussen 2016 en 2017.

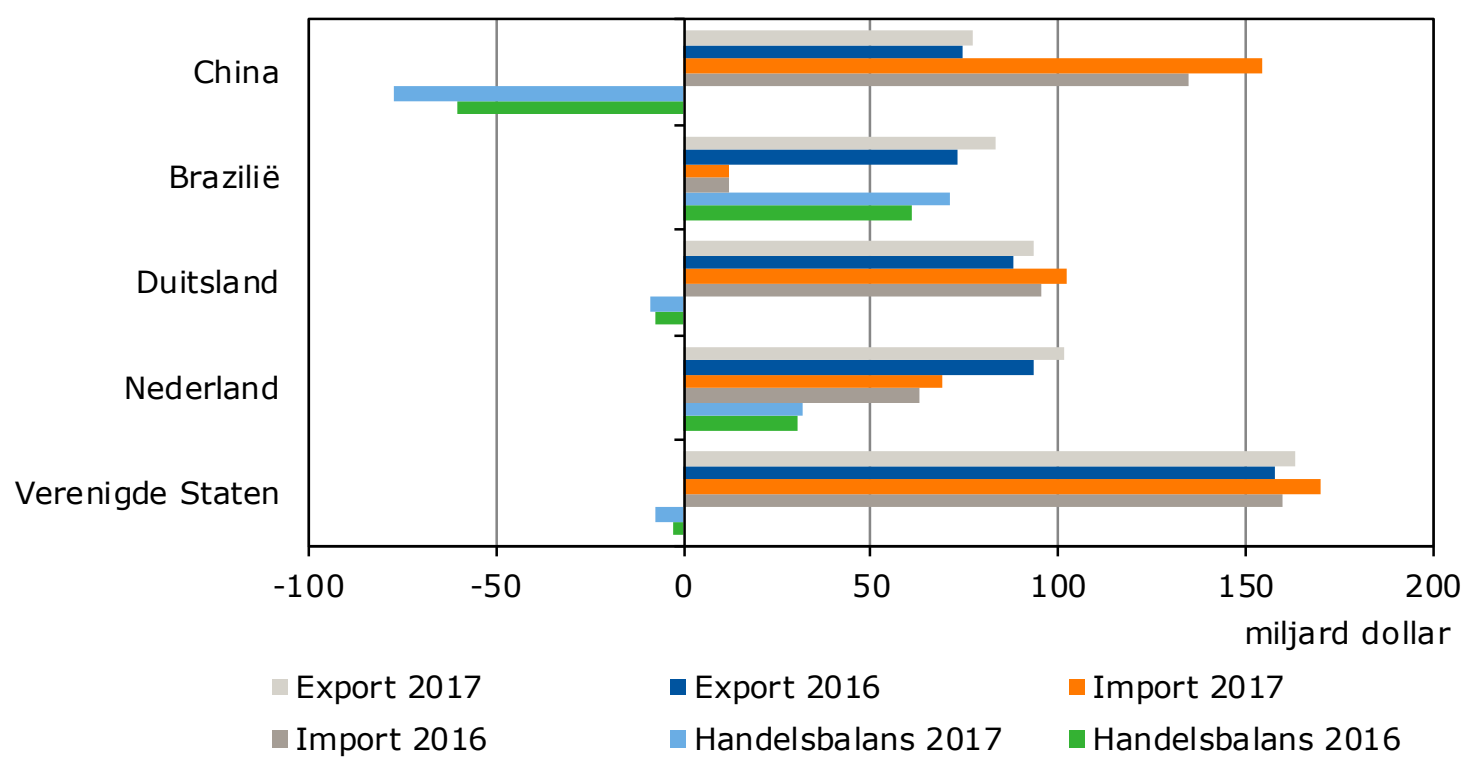

Figuur 4.1 De vijf grootste landbouwexporteurs van de wereld (in miljard dollar). Bron: Comtrade, bewerking Wageningen Economic Research. 


\subsection{Prijsdaling dempt waardeontwikkelingen}

In dit rapport staat de ontwikkeling van de exportwaarde centraal. Onderliggend spelen volume- en prijsontwikkelingen hierbij een rol. Bij de afdeling Nationale Rekeningen (NR) van het CBS worden de import- en exportcijfers op hoog niveau uitgesplitst naar volume- en prijsmutaties. Op een laag detailniveau wordt hierover niet gepubliceerd. De hieronder gepresenteerde ramingen zijn gebaseerd op NR-cijfers van de eerste drie kwartalen van 2018.

Op basis van NR-landbouwcijfers over de eerste drie kwartalen van 2018 kan worden gezegd dat de kleine exportwaardegroei door hoeveelheidsgroei komt en niet door prijsgroei. De eerder in deze publicatie gepresenteerde waardegroei van 0,2\% komt naar schatting voort uit een volumegroei van $0,9 \%$ en een prijsdaling van $0,7 \%$.

Binnen de basisdefinitie zijn er kleine verschillen tussen de primaire landbouwgoederen (uit landbouw, bosbouw, visserij) en de secundaire landbouwgoederen (zoals voedingsmiddelen, dranken en tabaksproducten). Zo is het uitvoervolume van de primaire landbouw met $0,6 \%$ gestegen en bij de secundaire landbouw met $1,0 \%$. De prijzen zijn sterker gedaald bij de secundaire goederen $(-1,0 \%)$ dan bij de primaire goederen $(-0,1 \%)$.

Tabel 4.1 Volume-, prijs- en wardeontwikkeling voor de landbouwexport, 2017-2018.

\begin{tabular}{lrr}
\multicolumn{1}{l}{ Nationale Rekeningen eerste drie kwartalen: } & Waardemutatie & Volumemutatie \\
\hline Landbouw-, bosbouw- en visserijproducten & $0,5 \%$ & $0,6 \%$ \\
\hline Voedingsmiddelen, dranken en tabaksproducten & $-0,1 \%$ & $-0,1 \%$ \\
\hline Landbouwgoederen totaal & $0,1 \%$ & $-1,0 \%$ \\
\hline Vertaald naar raming voor heel $\mathbf{2 0 1 8}$ & $\mathbf{0 , 2}, 0$ & $-0,7 \%$ \\
\hline
\end{tabular}

Bron: CBS.

Aan de invoerkant is het beeld redelijk vergelijkbaar. Ook hier is de prijsontwikkeling negatief en de volumeontwikkeling positief en is het volume-effect doorslaggevend. De eerder gepresenteerde waardegroei van $0,5 \%$ komt namelijk voort uit een geschatte volumegroei van $2,4 \%$ en een prijsdaling van $1,9 \%$.

Binnen de landbouwgoederen is er bij de invoer een duidelijk verschil tussen de volumeontwikkeling bij de primaire landbouwgoederen $(+4,2 \%)$ in vergelijking met de secundaire goederen $(+1,5 \%)$. De prijs daalt daarnaast sterker bij de primaire $(-2,9 \%)$ dan bij de secundaire landbouwgoederen $(-1,0 \%)$.

Tabel 4.2 Volume-, prijs- en waardeontwikkeling voor de landbouwimport, 2017-2018.

\begin{tabular}{|c|c|c|c|}
\hline & Waardemutatie & Volumemutatie & Prijsmutatie \\
\hline \multicolumn{4}{|l|}{ Nationale Rekeningen eerste drie kwartalen: } \\
\hline Landbouw-, bosbouw- en visserijproducten & $1,3 \%$ & $4,2 \%$ & $-2,9 \%$ \\
\hline Landbouwgoederen totaal & $0,8 \%$ & $2,6 \%$ & $-1,7 \%$ \\
\hline Vertaald naar raming voor heel 2018 & $0,5 \%$ & $2,4 \%$ & $-1,9 \%$ \\
\hline
\end{tabular}

Bron: CBS.

Op een dieper niveau is de publicatie van NR-cijfers niet toegestaan. Wel kan er iets worden gezegd over de richting. Bij hoeveel goederengroepen groeit of daalt het volume en bij hoeveel goederengroepen stijgt of daalt de prijs? Dit is weergegeven in tabel 4.3. Het macropatroon van volumegroei en prijsdaling komt nu ook terug. Bij de uitvoer wordt voor 25 van de 45 productgroepen een volumegroei genoteerd en voor 24 van de 45 een prijsdaling. De combinatie prijsdaling en 
volumegroei komt zelfs het meest voor (17 keer). Aan de invoerkant zijn er zelfs 29 productgroepen met volumegroei en 27 goederen met prijsdaling. Ook nu is de combinatie prijsdaling en volumegroei het meest voorkomend (20 keer).

Tabel 4.3 Volume-, prijs- en wardeontwikkeling voor de landbouwimport, 2017-2018.

\begin{tabular}{lll} 
Uitvoer & Volume daalt & Volume stijgt \\
Prijs daalt & 7 goederengroepen & 17 goederengroepen \\
\hline Prijs stijgt & 13 goederengroepen & 8 goederengroepen \\
\hline & & \\
\hline Invoer & Volume daalt & Volume stijgt \\
\hline Prijs daalt & 7 goederengroepen & 20 goederengroepen \\
\hline Prijs stijgt & 9 goederengroepen & 9 goederengroepen \\
\hline
\end{tabular}

Bron: CBS.

\subsection{Nederlandse landbouwgerelateerde machines in de lift}

De Nederlandse landbouwexport betreft zowel uitvoer van goederen van Nederlandse makelij als wederuitvoer. Wederuitvoer is invoer van buitenlandse productie die, al dan niet na lichte bewerking in Nederland, weer wordt uitgevoerd naar het buitenland. Wederuitvoer betreft bovendien goederen die tijdens het verblijf in Nederland (tijdelijk) in Nederlands eigendom zijn. Doorvoer van goederen van buitenlandse makelij die permanent in buitenlands eigendom zijn, wordt in de statistieken niet wederuitvoer genoemd, maar quasi-doorvoer. De quasi-doorvoerstromen worden wel gepubliceerd op Eurostat ('community concept'), maar niet door het CBS ('national concept'). Daarom blijft de landbouwexport in deze publicatie beperkt tot de uitvoer van goederen van Nederlandse makelij en tot wederuitvoer.

Voor 2018 wordt de landbouwexport (basisdefinitie) geraamd op 90,3 miljard euro, zoals vermeld in paragraaf 2.1. Dit bedrag is samengesteld uit 65,4 miljard euro aan uitvoer van goederen van Nederlandse makelij en 24,9 miljard euro aan wederuitvoer. Bij de landbouwgerelateerde goederen gaat het om 6,9 miljard euro aan uitvoer van goederen van Nederlandse makelij en 2,3 miljard euro aan wederuitvoer. Dat geeft een totale 'brede' landbouwexportomvang van 72,3 miljard euro aan export van goederen van Nederlandse makelij en 27,2 miljard euro aan wederuitvoer.

In vergelijking met 2017 zijn de meeste verschillen minimaal. De enige uitschieter betreft de export van Nederlandse landbouwgerelateerde goederen. Hier is de groei met bijna $5 \%$ een stuk positiever dan bij de wederuitvoer $(-1,3 \%)$. De groei bij de uitvoer van goederen van Nederlandse makelij komt volledig voor rekening van landbouwmachines, zoals sorteermachines, melkrobots en veevoederbereiders (+96 miljoen euro; $+5 \%$ ) en machines voor de voedingsmiddelenindustrie, zoals voor de bereiding of verwerking van chocolade, vlees, vruchten, groenten en dranken (+261 miljoen euro; $+17 \%)$. 


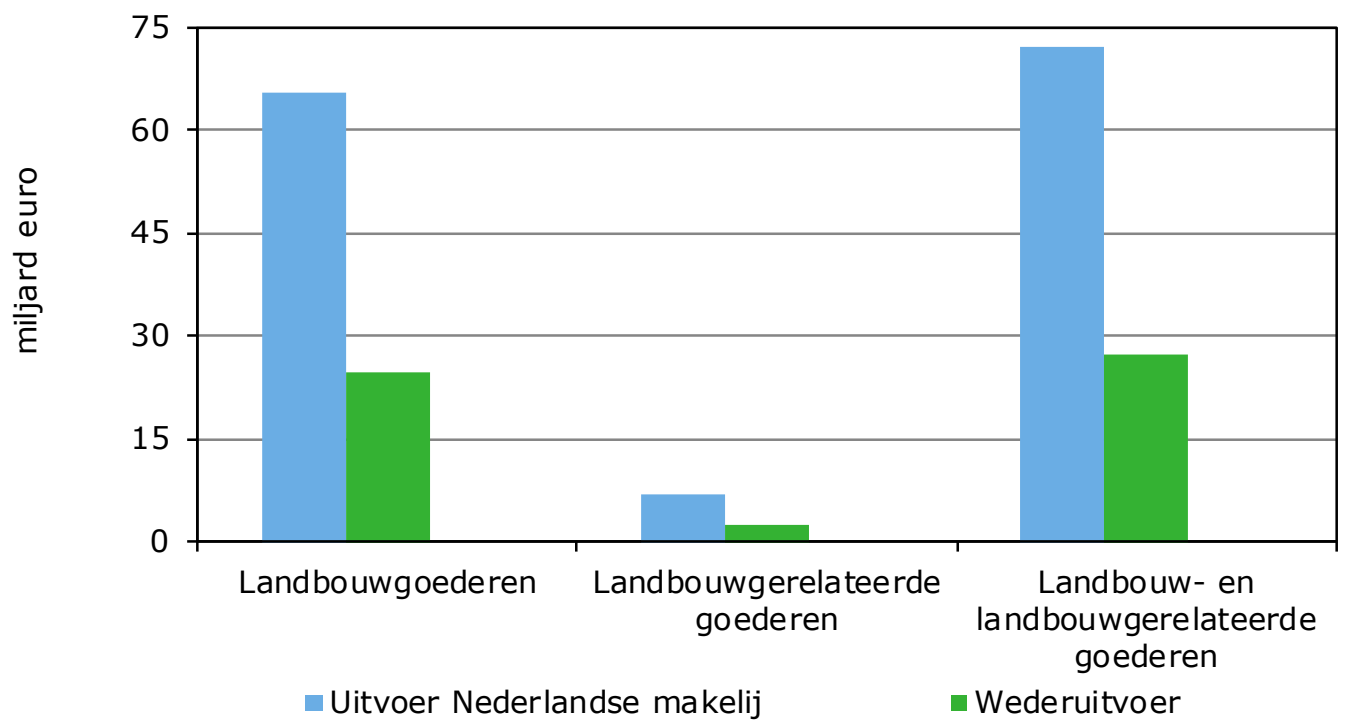

Figuur 4.2 Samenstelling van de Nederlandse landbouwexport 2018.

Bron: CBS tot en met oktober 2018, raming november - december 2018 door WUR en CBS.

\subsubsection{Relatief weinig wederuitvoer in Nederlandse landbouw}

Door de toename van Nederlandse machines in de landbouwexport is het wederuitvoeraandeel in de tertiaire landbouw afgenomen van $26,2 \%$ in 2017 tot $25,1 \%$ in 2018 . In de primaire en secundaire landbouw is het wederuitvoeraandeel iets gestegen van $27,5 \%$ tot $27,6 \%$. In de brede definitie van de landbouwexport is er daarom slechts een minimale afname van het percentage wederuitvoer, van $27,4 \%$ naar $27,3 \%$ wederuitvoer.

Niet-landbouwgoederen, zoals computers, telefoons en kleding van buitenlandse makelij (zie ook Kuypers et al., 2012), hebben traditioneel veel meer wederuitvoer dan landbouwgoederen. Het wederuitvoerpercentage bij de niet-landbouwgoederen is met 49,1\% iets hoger dan in $2017(48,7 \%)$. De totale goederenexport heeft daarmee 44,7\% wederuitvoer in 2018.

Het veel lagere wederuitvoerpercentage bij de landbouwgoederen betekent dat Nederland aan een euro landbouwexport veel meer overhoudt dan aan een euro export van overige goederen. Aan een euro export van goederen van Nederlandse makelij verdient de Nederlandse economie immers gemiddeld ruim vijf keer meer dan aan een euro uit wederuitvoer (57 om 11 eurocent per euro uit export, CBS 2016a). In paragraaf 4.4 wordt specifiek ingegaan op de Nederlandse landbouwexportverdiensten per euro. 


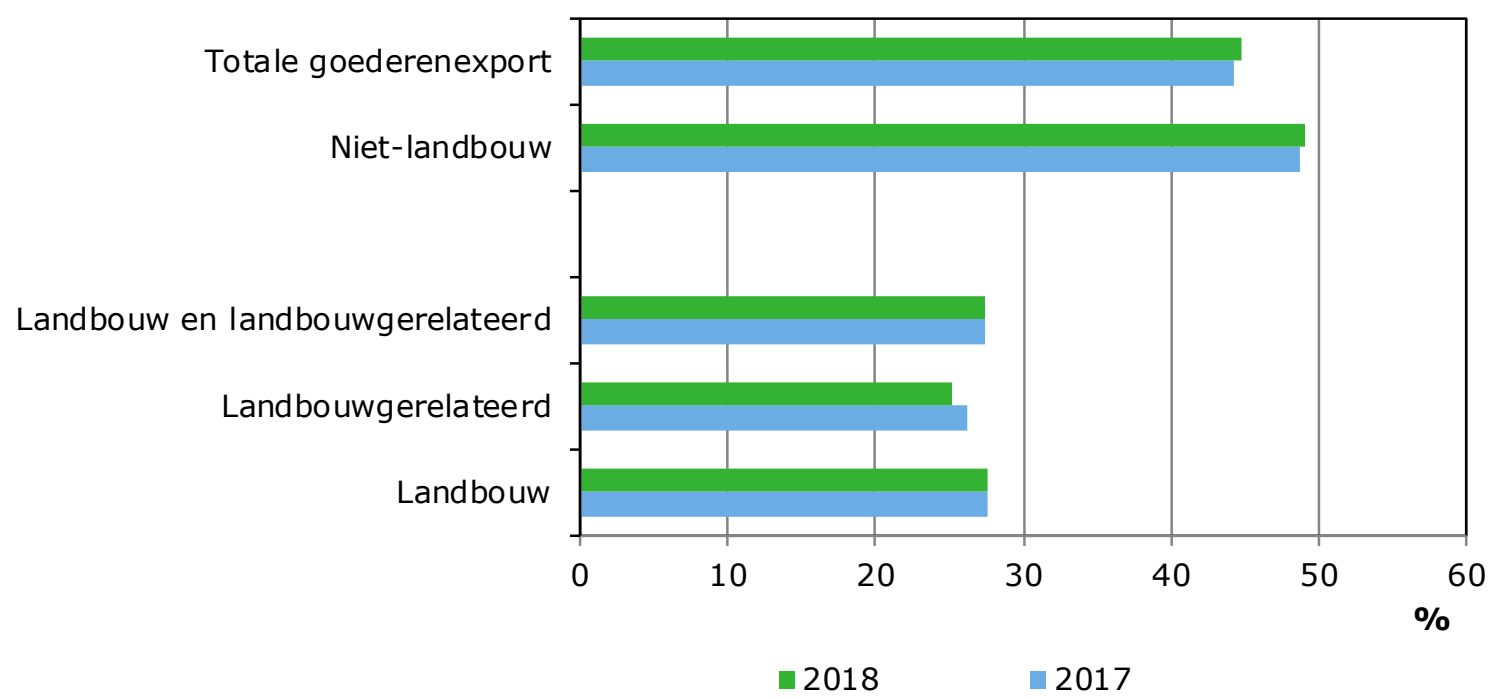

Figuur 4.3 Aandeel wederuitvoer in Nederlandse uitvoerstromen.

Bron: CBS tot en met oktober 2018, raming november - december 2018 door WUR en CBS.

\subsubsection{Fruit traditioneel veel wederuitvoer}

De belangrijkste tien landbouwgroepen in de export (volgens de eerste twee digits van de GNnomenclatuur) zijn weergegeven in tabel 4.4. De eerste zes zijn dezelfde zes als in 2017. Dat zijn sierteelt $(9,2$ miljard euro exportwaarde), zuivel en eieren $(8,5)$, vlees $(8,1)$, groenten $(6,6)$, fruit $(6,0)$ en dranken $(5,2)$. Van die zes is fruit met afstand het vaakst van buitenlandse makelij. Het wederuitvoerpercentage komt hier uit op $77 \%$ en dat is veel meer dan bij sierteelt (12\%), zuivel en eieren $(18 \%)$, vlees $(11 \%)$, groenten $(16 \%)$ en dranken $(25 \%)$.

Zonder wederuitvoer blijft sierteelt bovenaan staan als meest geëxporteerde goederengroep (volgens de GN-goederenindeling). Vlees (relatief weinig wederuitvoer) passeert dan zuivel en eieren voor plek twee en groente blijft op een vierde positie staan. Bereidingen van graan, meel en melk springen ten koste van de fruitexport naar plek vijf en dranken blijven op zes.

In vergelijking met 2017 zit de grootste absolute groei in de export van goederen van Nederlandse makelij bij sierteelt en bereidingen van graan, meel en melk (met name babymelkpoeder naar China). Het gaat om toenames van respectievelijk 291 en 379 miljoen euro in een jaar tijd. De wederuitvoer groeit absoluut het sterkst bij fruit (met 327 miljoen euro). Zie bijlage 4 voor een totaaloverzicht op goederenniveau. 


\begin{tabular}{|c|c|c|c|c|c|c|}
\hline \multirow[b]{3}{*}{ Alle landbouwgoederen } & \multicolumn{3}{|c|}{2017} & \multicolumn{3}{|c|}{2018} \\
\hline & \multirow{2}{*}{$\begin{array}{l}\text { Nederlandse } \\
\text { makelij } \\
65,3\end{array}$} & \multirow{2}{*}{$\begin{array}{l}\text { Weder- } \\
\text { uitvoer } \\
\mathbf{2 4 , 8}\end{array}$} & \multirow{2}{*}{$\begin{array}{l}\text { Totaal } \\
\text { 90,1 }\end{array}$} & \multirow{2}{*}{$\begin{array}{l}\text { Nederlandse } \\
\text { makelij } \\
65,4\end{array}$} & \multirow{2}{*}{$\begin{array}{r}\text { Weder- } \\
\text { uitvoer } \\
\mathbf{2 4 , 9}\end{array}$} & \multirow{2}{*}{$\begin{array}{l}\text { Totaal } \\
\qquad \mathbf{9 0 , 3}\end{array}$} \\
\hline & & & & & & \\
\hline \multicolumn{7}{|l|}{10 belangrijkste goederengroepen ( 2 digits $G N$-code) } \\
\hline GN-06 Sierteelt & 7,8 & 1,1 & 8,9 & 8,1 & 1,1 & 9,2 \\
\hline GN-04 Zuivel en eieren & 7,0 & 1,7 & 8,7 & 6,9 & 1,6 & 8,5 \\
\hline GN-02 Vlees & 7,1 & 1,1 & 8,2 & 7,2 & 0,9 & 8,1 \\
\hline GN-07 Groenten & 5,6 & 1,0 & 6,6 & 5,6 & 1,0 & 6,6 \\
\hline GN-08 Fruit & 1,2 & 4,3 & 5,5 & 1,4 & 4,6 & 6,0 \\
\hline GN-22 Dranken & 3,8 & 1,3 & 5,1 & 3,9 & 1,3 & 5,2 \\
\hline GN-20 Bereidingen van groente en fruit & 3,5 & 1,5 & 4,9 & 3,6 & 1,5 & 5,1 \\
\hline GN-19 Bereidingen van graan, meel, melk & 3,6 & 0,7 & 4,3 & 4,0 & 0,8 & 4,8 \\
\hline GN-23 Resten voedselindustrie, veevoer & 2,9 & 1,4 & 4,3 & 3,0 & 1,4 & 4,5 \\
\hline GN-18 Cacao en cacaobereidingen & 3,1 & 1,6 & 4,8 & 2,7 & 1,7 & 4,4 \\
\hline Alle landbouwgerelateerde goederen & 6,6 & 2,3 & 8,9 & 6,9 & 2,3 & 9,2 \\
\hline $\begin{array}{l}\text { Totaal landbouw en landbouwgerelateerde } \\
\text { goederen }\end{array}$ & 71,8 & 27,1 & 99,0 & 72,3 & 27,2 & 99,5 \\
\hline
\end{tabular}

Bron: CBS tot en met oktober 2018, raming november - december 2018 door WUR en CBS.

\subsubsection{Verenigd Koninkrijk derde bestemming voor Nederlandse producten}

In paragraaf 2.2 werd getoond dat het Verenigd Koninkrijk na Duitsland en België de belangrijkste afnemer is in de Nederlandse landbouwexport. Door verbijzondering naar wederuitvoer en uitvoer van goederen van Nederlandse makelij kan ook worden getoond dat het VK de derde afnemer van Nederlandse landbouw (hier inclusief tertiaire goederen) is, met een bedrag van 6,8 miljard euro in 2018. Dat is minder dan Duitsland (16,0 miljard) en België (7,5 miljard), maar meer dan Frankrijk (5,9 miljard), Italië (2,9 miljard) en de VS (2,8 miljard). Het percentage wederuitvoer in de exportwaarde naar onze buurlanden is relatief hoog met 34\% (Duitsland) en 33\% (België). Bij de export naar het Verenigd Koninkrijk (26\%), Frankrijk (30\%), Italië $(22 \%)$ en de VS (10\%) is er beduidend minder wederuitvoer.

De tien belangrijkste afnemers van Nederlandse landbouwproducten zijn ook de tien belangrijkste afnemers in de totale Nederlandse landbouwexport. De volgorde is wel iets anders. Dat komt doordat China bovengemiddeld veel Nederlandse producten afneemt (zoals babymelkpoeder). Daarmee is China niet de achtste, maar de zevende bestemming voor Nederland (in plaats van Spanje).

In vergelijking met 2017 zijn er weinig grote verschillen. De grootste ontwikkeling zit in de export naar Frankrijk. Daarin is de exportwaarde van goederen van Nederlandse makelij een stuk lager (van 6,2 naar 5,9 miljard euro). Een totaaloverzicht op landenniveau is opgenomen in bijlage 4 . 


\begin{tabular}{|c|c|c|c|c|c|c|}
\hline & \multicolumn{3}{|c|}{2017} & \multicolumn{3}{|c|}{2018} \\
\hline & $\begin{array}{l}\text { Nederlandse } \\
\text { makelij }\end{array}$ & $\begin{array}{l}\text { Weder- } \\
\text { uitvoer }\end{array}$ & Totaal & $\begin{array}{l}\text { Nederlandse } \\
\text { makelij }\end{array}$ & $\begin{array}{l}\text { Weder- } \\
\text { uitvoer }\end{array}$ & Totaal \\
\hline EU-28 & 51,7 & 23,6 & 75,3 & 51,5 & 23,6 & 75,1 \\
\hline Niet-EU & 20,1 & 3,5 & 23,7 & 20,8 & 3,6 & 24,4 \\
\hline Duitsland & 16,1 & 8,4 & 24,5 & 16,0 & 8,2 & 24,2 \\
\hline België & 7,5 & 3,5 & 11,1 & 7,5 & 3,7 & 11,2 \\
\hline Verenigd Koninkrijk & 6,8 & 2,5 & 9,3 & 6,8 & 2,4 & 9,2 \\
\hline Frankrijk & 6,2 & 2,4 & 8,6 & 5,9 & 2,6 & 8,4 \\
\hline China & 2,3 & 0,3 & 2,6 & 2,4 & 0,3 & 2,7 \\
\hline Polen & 1,7 & 0,9 & 2,6 & 1,8 & 0,9 & 2,7 \\
\hline Zweden & 1,5 & 0,6 & 2,1 & 1,5 & 0,6 & 2,1 \\
\hline
\end{tabular}

Bron: CBS tot en met oktober 2018, raming november - december 2018 door WUR en CBS.

\subsection{Nederland verdient meest aan traditionele landbouwexport}

In al het voorgaande is uitgegaan van exportwaarden, dus de omzetwaarden van de landbouwexport bij het overschrijden van de Nederlandse landsgrens. Uit deze cijfers valt niet zomaar af te leiden hoeveel de Nederlandse economie eraan verdient. Voor elke euro aan export is namelijk import van goederen en diensten nodig. Soms is het importdeel heel groot. Dat is met name het geval bij de buitenlandse landbouwgoederen die Nederlandse bedrijven importeren en vervolgens verkopen aan het buitenland. Aan deze wederuitvoer verdient Nederland per euro aan export relatief weinig. Aan andere goederen verdient Nederland relatief veel. Dat komt doordat goederen vrijwel rechtstreeks uit de natuur komen of doordat er wel bewerking nodig is, maar de benodigde grondstoffen, halffabricaten of diensten uit Nederland komen en niet uit het buitenland.

Op basis van cijfers over 2017 van de afdeling Nationale Rekeningen van het CBS zijn toegevoegde waardecijfers geschat voor de export van landbouwgoederen. Deze cijfers geven inzicht in de exportverdiensten ${ }^{6}$ : aan welke landbouwgoederen verdient Nederland via de export het meest? Daarbij is het goed om te bedenken dat alle verdiensten in de Nederlandse economie worden meegerekend die te danken zijn aan de landbouwexport. Niet alleen de directe landbouwverdiensten die te danken zijn aan de export door bedrijven in de landbouwsector of de voedingsmiddelenindustrie, maar ook de verdiensten van alle andere bedrijven in de toeleveringsketen van de landbouwexport. Dat kan heel ver gaan: zelfs de accountant van het schoonmaakbedrijf dat een exporterende voedingsmiddelenfabriek schoonmaakt, telt voor een klein gedeelte mee. Zo verdienen dus ook dienstensectoren aan de export van landbouwgoederen.

De gehele landbouwexport leverde in 2018 ongeveer hetzelfde op als in 2017 (nauwelijks verschillen tussen beide jaren), namelijk naar schatting 45 miljard euro $^{7}$ aan exportverdiensten. In 2018 gaat het om circa 41,5 miljard euro door de export van goederen van Nederlandse makelij en 3,5 miljard euro

\footnotetext{
6 In deze paragraaf gaat het om exportverdiensten die te danken zijn aan de export van landbouwgoederen, oftewel de exportwaarde minus de waarde van de import van goederen en diensten die nodig zijn om de goederen te exporteren en eventueel te produceren. Exportverdiensten zijn vrijwel hetzelfde begrip als de toegevoegde waarde die voortkomt uit de landbouwexport. Het verschil betreft het saldo van productgebonden belastingen en subsidies. Hier is gekozen voor exportverdiensten, inclusief het saldo van productgebonden belastingen en subsidies, omdat dit als voordeel heeft dat vergelijkingen kunnen worden gemaakt met het bbp tegen marktprijzen.

7 Dit ligt een stuk lager dan vorig jaar geraamd voor 2017. Dit komt voornamelijk door een grote datarevisie bij Nationale Rekeningen dit jaar. Zie de dataverantwoording voor verdere details.
} 
door wederuitvoer. Een verdere uitsplitsing laat zien dat de 41,5 miljard door goederen van Nederlandse makelij voor 37,8 miljard euro primaire en secundaire landbouwgoederen betreft en voor 3,7 miljard tertiaire goederen. De 3,5 miljard wederuitvoerverdiensten betreffen voor 3,25 miljard euro aan primaire en secundaire landbouwgoederen en voor 0,25 miljard euro aan tertiaire.

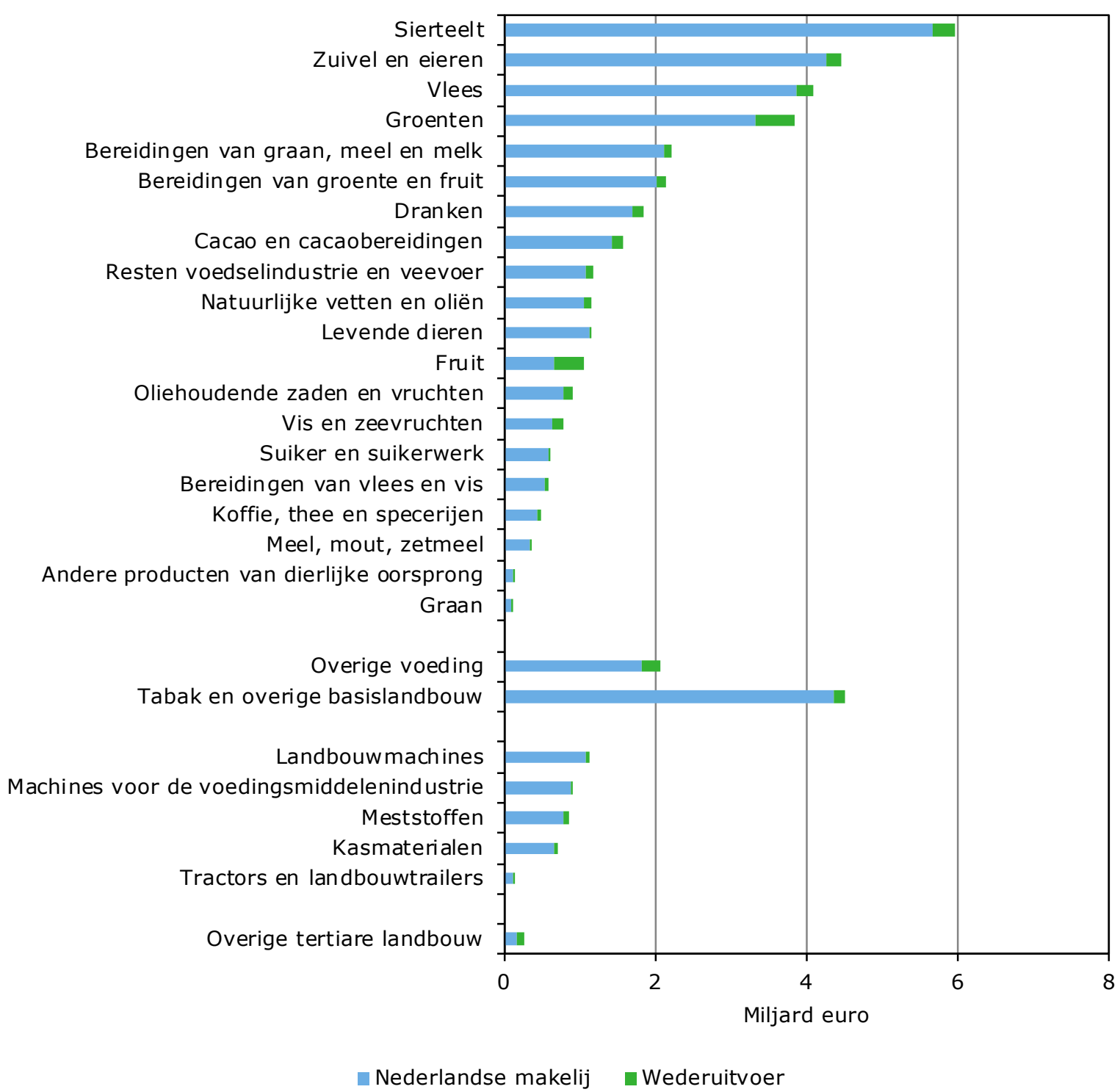

Figuur 4.4 Exportverdiensten aan landbouwgoederen, inclusief tertiaire goederen, 2017. Bron: CBS.

Een blik op de verschillende landbouwgoederen leert dat Nederland nog altijd het meest verdient aan de traditionele landbouw: het meest aan sierteelt (6,0 miljard euro), gevolgd door zuivel en eieren (4,7 miljard), vlees (4,1 miljard), groenten (3,8 miljard) en bereidingen van graan, meel en melk, zoals babymelkpoeder (2,2 miljard). Ook traditioneel hoog staan bereidingen van groente en fruit (2,2 miljard), dranken (1,8 miljard) en cacaobereidingen (1,6 miljard). Bij de tertiaire landbouw zijn de verdiensten het hoogst bij landbouwmachines (1,3 miljard), voedingsmachines, meststoffen (beide 0,9 miljard) en kasmaterialen (0,7 miljard).

De bijdrage van de wederuitvoer aan de Nederlandse exportverdiensten is bij landbouwgoederen relatief laag. In de eerste plaats is het percentage wederuitvoer bij de landbouw relatief laag (zie paragraaf 4.3) en in de tweede plaats is de toegevoegde waarde per euro aan uitvoer bij de wederuitvoer beperkt (zie 4.4.1). 


\subsubsection{4 eurocent exportverdiensten per euro export}

In de totale landbouwexport zijn de verdiensten 44 eurocent voor elke euro die over de grens gaat. Voor een euro aan wederuitvoer is dat 10 eurocent, maar voor een euro aan goederen van Nederlandse makelij is dat zes keer zoveel: 61 eurocent. Dezelfde verhoudingen zijn zichtbaar bij de primaire en secundaire landbouw. Bij de tertiaire landbouw liggen de verdiensten per euro iets hoger (49 eurocent), omdat hier het aandeel wederuitvoer wat lager ligt. Bovendien levert een euro aan wederuitvoer iets meer op (11 eurocent) en dat geldt ook voor een euro aan uitvoer van goederen van Nederlandse makelij (65 eurocent).

Op goederenniveau zijn de exportverdiensten per euro het hoogste bij de bloembollen (76 eurocent per euro aan export), ook omdat vrijwel alle geëxporteerde goederen van Nederlandse makelij zijn. Erg laag zijn de exportverdiensten bij fruit (20 eurocent), vanwege het hoge aandeel goederen van buitenlandse makelij. Als we alleen rekening houden met de export van goederen van Nederlandse makelij, dan liggen de hoogste exportverdiensten per euro bij sierteelt (84 eurocent), groenten (81 eurocent), oliehoudende zaden en vruchten (83 eurocent) en nu ook fruit (80 eurocent). Bij de tertiaire landbouwgoederen liggen de verdiensten per euro nu een stuk lager, omdat hier vaak meer import nodig is, bijvoorbeeld van machineonderdelen.

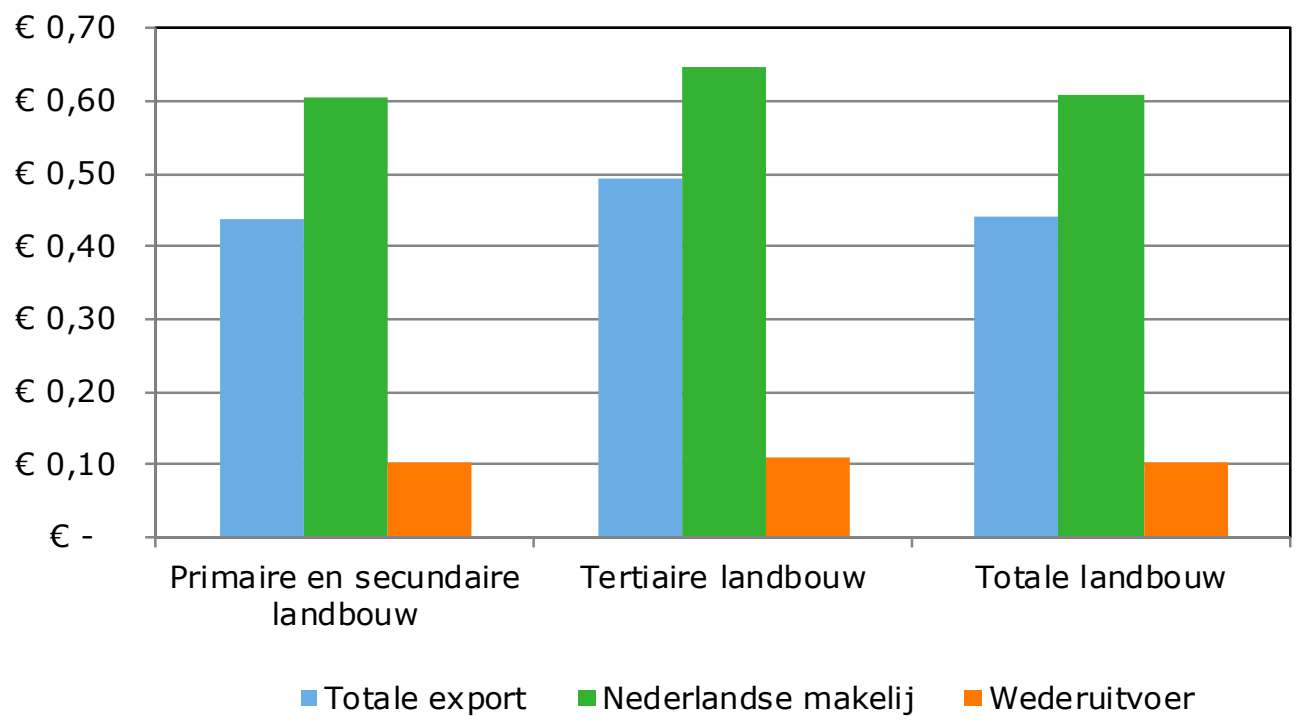

Figuur 4.5 Exportverdiensten per euro aan export, 2017.

Bron: $C B S$. 


\section{$5 \quad$ Kennis-, innovatie- en duurzaamheidsaspecten van internationalisering}

In dit hoofdstuk wordt ingegaan op kennis-, innovatie- en duurzaamheidsaspecten van de Nederlandse landbouwhandel, door andere statistieken met een internationale component dan de goederenhandel te verbinden met de agribusiness. In de eerste paragraaf wordt getoond dat de Nederlandse agribusiness naast goederen ook diensten exporteert. Daarna wordt het belang van R\&D en innovatie in de agribusiness gekwantificeerd, gevolgd door een focus op patentaanvragen in de voedingsmiddelen- en drankenindustrie. De kennispositie van Nederland als landbouwland wordt ook uitgelicht, door te kijken naar het aantal buitenlandse dochterbedrijven in Nederland en het aantal Nederlandse dochterbedrijven in het buitenland. Daarnaast komt de Nederlandse kennispositie tot uitdrukking in het aantal internationale studenten dat aan de universiteit Wageningen komt studeren. Het hoofdstuk wordt afgesloten met enkele duurzaamheidscijfers, door een blik op de biologische agro/food sector en op de invoer van duurzame agrogrondstoffen uit met name derdewereldlanden.

\subsection{Agribusiness importeert meer diensten dan het exporteert}

Recent is bij het CBS een nieuw microdatabestand ontwikkeld met data over de internationale handel in diensten. Door gebruik te maken van dit bestand, beschikt het CBS per bedrijf over schattingen van de omvang van de dienstenhandel ten aanzien van verschillende bedrijfskenmerken. Het bestand bevat geen bedrijven in de financiële sector of bijschattingen van financiële diensten. Ook zijn de bestedingen van toeristen niet opgenomen. Hierdoor liggen de cijfertotalen circa een derde lager dan de cijfertotalen op StatLine (Smit en Wong, 2017).

De agribusiness (zie de dataverantwoording voor de precieze definitie) importeert meer diensten dan het exporteert. Dat is sinds 2012 elk jaar het geval geweest. Het dienstenhandelstekort neemt zelfs toe en komt uit op 2,4 miljard euro in 2016. Dat is het resultaat van een dienstenimport van 4,7 miljard euro en een dienstenexport van 2,3 miljard euro. Zowel de invoer als de uitvoer zijn geleidelijk in waarde toegenomen. Ook het aantal dienstenhandelaren in de agribusiness neemt toe. Het aantal importeurs is gestegen van 13,4 duizend in 2012 tot 17,6 duizend in 2016 en het aantal exporteurs nam toe van 2,7 duizend tot 3,5 duizend. Daarmee is ook te zien dat een gemiddelde dienstenexporteur voor meer geld uitvoert dan de gemiddelde dienstenimporteur aan waarde invoert.

In vergelijking met de totale dienstenhandel door bedrijven in de Nederlandse economie is de dienstenhandel door de agribusiness vrij gering in omvang. Bij de import gaat het om een agroaandeel van $4,5 \%$ en bij de export om een aandeel van $2 \%$. 


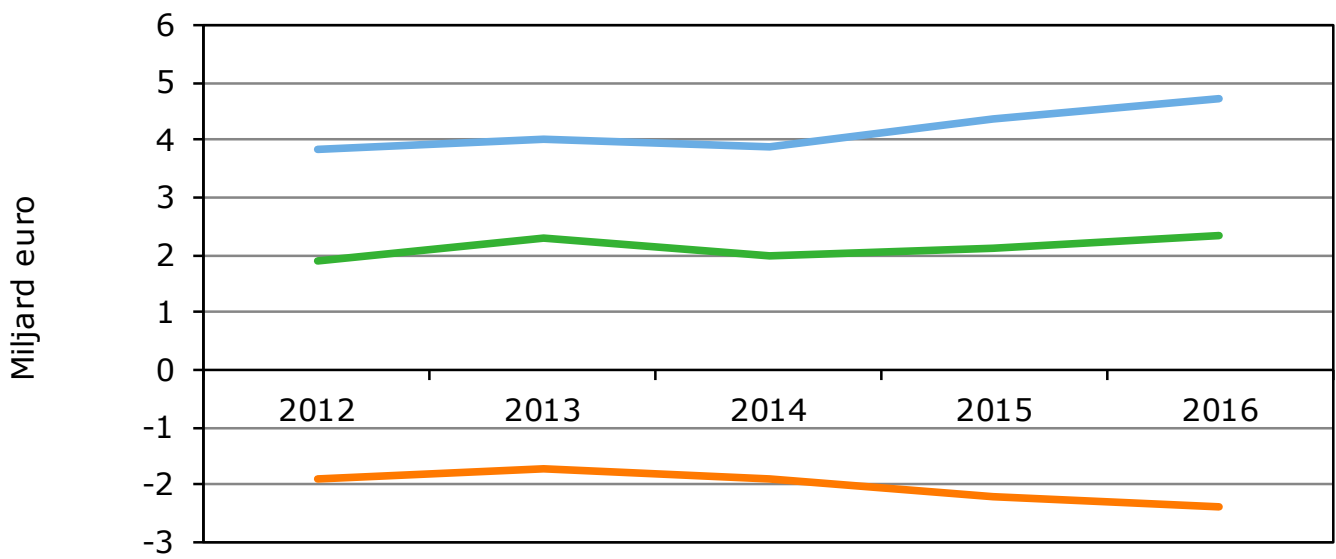

Invoer Uitvoer $=$ Handelsbalans

Figuur 5.1 Ontwikkeling van de internationale dienstenhandel door de agribusiness (miljard euro). Bron: $C B S$.

\subsubsection{Dienstenhandel vooral EU-aangelegenheid}

De invoer uit EU-landen is in de dienstenhandel toonaangevend en in deze stroom zit de laatste jaren ook de grootste groei: van 3,1 miljard euro in 2012 tot 3,7 miljard in 2016. Ook in de Nederlandse export is de EU toonaangevend, maar hier zijn de verschillen met de niet-EU-landen een stuk kleiner dan bij de import. In 2016 werd door de agribusiness voor 1,5 miljard euro geëxporteerd naar EUlanden en voor 0,9 miljard euro naar andere landen.

Op landniveau is er alleen iets te zeggen over de EU-landen. De belangrijkste dienstenleveranciers binnen de EU zijn België (25\%), Duitsland (23\%), Frankrijk (14\%) en het Verenigd Koninkrijk (10\%). Dat zijn ook de belangrijkste bestemmingen, maar daarbij wisselen de buurlanden van positie: Duitsland (22\%), België (18\%), Frankrijk (16\%) en het Verenigd Koninkrijk (12\%).

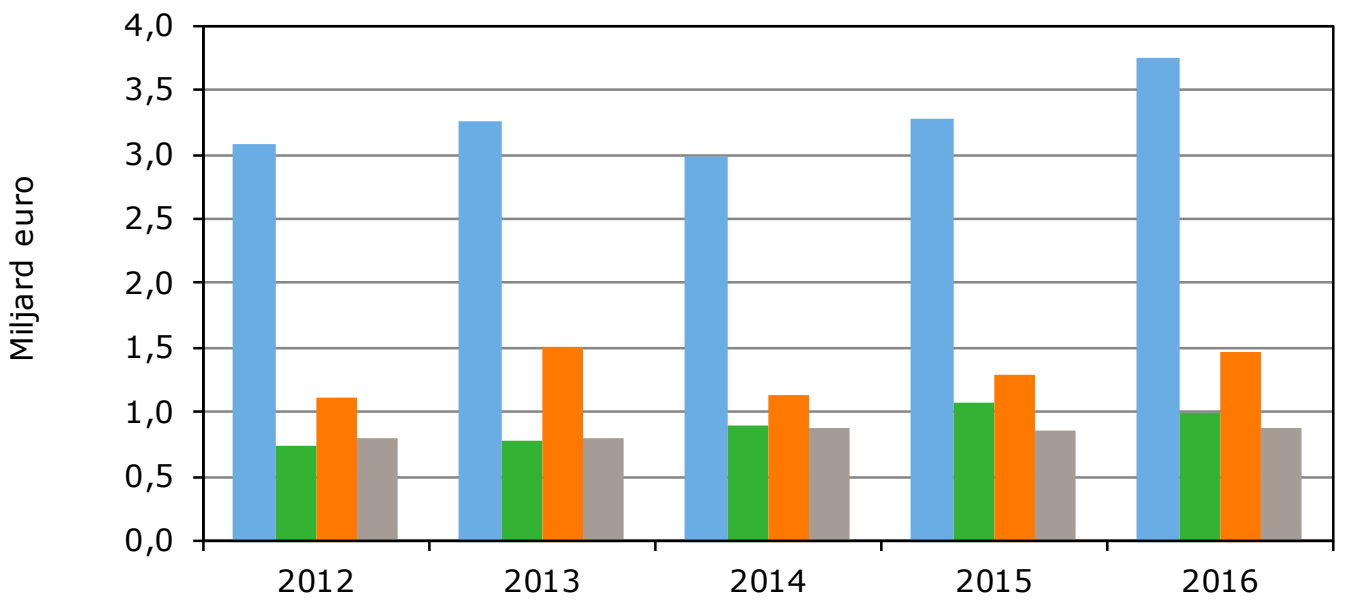

$\square$ Invoer uit EU $\quad$ Invoer uit niet-EU $\quad$ Uitvoer naar EU $\quad$ Uitvoer naar niet-EU

Figuur 5.2 Verhouding tussen EU en niet-EU in de dienstenhandel door de agribusiness. Bron: $C B S$. 


\subsubsection{Voedingsmiddelenindustrie en groothandel dominant}

Op bedrijfsactiviteitenniveau (SBI) zijn het de voedingsmiddelenindustrie en de agrarische groothandel die het meeste diensten verhandelen met het buitenland. De sector 'vervaardiging en verwerking van overige voedingsmiddelen' (zoals chocolade, suikerwerk, koffie, thee, sauzen, kant-en

klaarmaaltijden, snacks, voedingspreparaten en dieetvoeding) is zowel de belangrijkste leverancier als de belangrijkste afnemer van diensten. Andere branches die veel diensten verhandelen, zijn de groothandel in landbouwproducten en levende dieren, de groothandel in voedings- en genotmiddelen, de verwerking van aardappelen, groente en fruit, de vervaardiging van zuivelproducten en de vervaardiging van natuurlijke oliën en vetten.

Een vergelijking door de tijd leert dat de grootste groei in de dienstenhandel zit in de vervaardiging en verwerking van overige voedingsmiddelen, zowel bij de in- als de uitvoer.

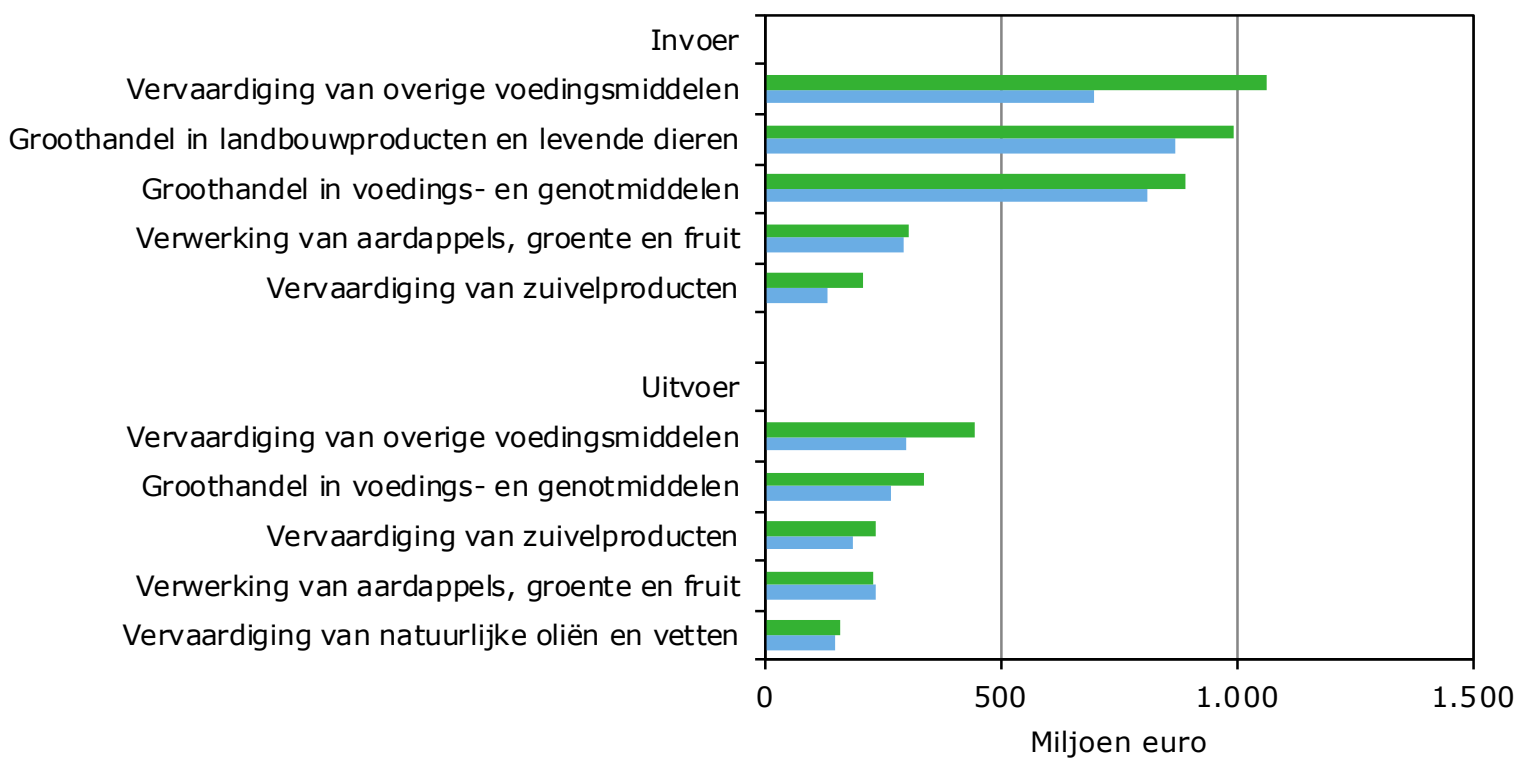

- $2016 \square 2012$

Figuur 5.3 Top vijf sectoren in de in- en uitvoer van diensten door de agribusiness. Bron: $C B S$.

\subsubsection{Veel diensten verbonden aan be- en verwerking van goederen}

Nog interessanter dan de identiteit van de dienstenhandelaren is de precieze inhoud van de dienstenhandel. Een blik op de meeste verhandelde dienstensoorten laat zien dat de dienstenhandel en de goederenhandel elkaar nodig hebben. Zo zijn diensten verbonden aan de be- en verwerking van goederen na wegvervoer de meest ingevoerde en de meest uitgevoerde diensten. Het gaat hier om het verwerken, labelen of verpakken door buitenlandse bedrijven die niet de eigenaar van de goederen zijn. De overige 18 dienstensoorten in de top twintig vallen grofweg in te delen in drie categorieën: vervoersdiensten (zeevaart, luchtvaart, binnenvaart, overig vervoer), kennisintensieve diensten (R\&D-diensten, vergoedingen voor R\&D, wetenschappelijke diensten, computerdiensten, primaire landbouwdiensten, onderhoud en reparatie) en zakelijke diensten (zakelijk advies, aan de handel verbonden diensten, adverteren, marktonderzoek en accounting). 


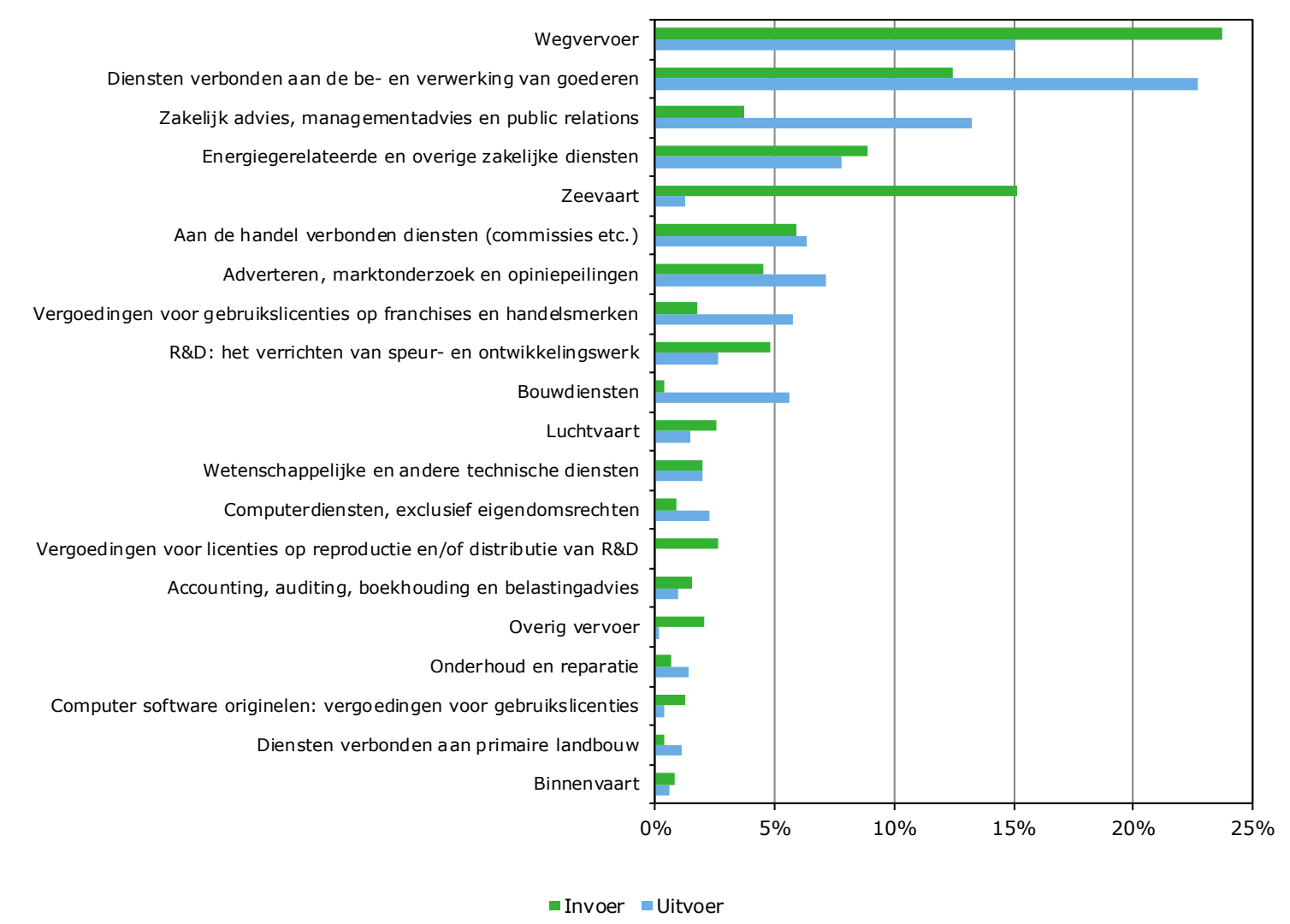

Figuur 5.4 Top twintig dienstensoorten agribusiness, 2018.

Bron: $C B S$.

\subsubsection{Overige kenmerken van dienstenhandelaren}

Verder onderzoek naar de kenmerken van dienstenhandelaren in de agribusiness laat zien dat circa $88 \%$ van de handelswaarde afkomstig is uit handelsstromen van boven de 10 miljoen euro (12\% door kleinere handelsstromen). Daarnaast is circa drie kwart van de handel verricht door het grootbedrijf en circa een kwart door het zelfstandig MKB. Ook valt op dat het meest aan dienstenimport wordt gedaan door buitenlandse bedrijven in Nederland (63\%) en minder door Nederlandse bedrijven (37\%). Bij de dienstenexport is het meer in evenwicht (48\% door Nederlandse bedrijven).

\subsection{Innovatie en R\&D volop in de aandacht}

Nederland heeft een prominente positie in de wereld als het gaat om kennis en innovatie. Het kabinet blijft een actieve rol spelen in het stimuleren van de innovatiekracht en nieuwe kennis. Er wordt 400 miljoen euro per jaar vrijgemaakt voor fundamenteel en toegepast onderzoek (regeerakkoord 2017-2021). Hierbij wordt onder andere de focus gelegd op publiek-private samenwerking bij universiteiten en hogescholen, op bèta en techniek en op de topsectoren. Een van de hoofdthema's in het topsectorenbeleid is landbouw, water en voedsel. Ook wordt incidenteel 15 miljoen euro vrijgemaakt voor het innovatieprogramma voor visserij.

Nauwe en geconcentreerde samenwerking tussen universiteiten en researchinstituten wordt in de voedselsector gerealiseerd met de bouw van het Global Foods Innovation Centre van Unilever in Wageningen (Unilever 2017, Unilever 2018). Ook het Digital Food Processing Initiative, dat op 29 juni jongstleden werd gelanceerd door Wageningen University \& Research (WUR) samen met TNO en TU Eindhoven (Dros, 2018), is een voorbeeld van een dergelijke nieuwe strategische samenwerking. De ambitie van dit initiatief is om wereldwijd het toonaangevende centrum te worden dat de terreinen Food \& Nutrition en High-Tech verbindt. 
In deze paragraaf gaan we dieper in op R\&D en innovatie in de agribusiness sector, bestaande uit land- en tuinbouw, visserijen en de relevante toeleveranciers en afnemers (zie ook CBS, 2016b). Bij innovatie wordt onderscheid gemaakt tussen technologische en niet-technologische innovatie. Technologische innovatie is de ontwikkeling en succesvolle invoering van nieuwe of verbeterde producten en diensten en productie- en distributieprocessen. Niet-technologische innovatie omvat marketing- en organisatorische innovatie. In dit hoofdstuk ligt de focus op technologische innovatie. $R \& D$ is fundamenteel wetenschappelijk en toegepast onderzoek naar nieuwe kennis en technologie. Omdat het de bedoeling is dat de ontwikkelde kennis en technologie uitmonden in concrete nieuwe producten en processen, oftewel de innovatie, zijn de R\&D-uitgaven een onderdeel van de bredere technologische innovatie-uitgaven.

Concreet kan bij innovaties in de agribusiness worden gedacht aan kweekvlees uit stamcellen, zodat er uiteindelijk geen dieren meer gedood hoeven te worden om in de vleesproductie te voorzien. Bovendien zal naar alle waarschijnlijkheid de belasting voor het milieu door de nieuwe vleesproductie verminderd worden (Hosselet, 2017). Er kan ook worden gedacht aan meststoffen om planten en bloemen sneller te laten groeien. Ook onderzoek naar biobased stoffen vindt plaats in de agribusiness, bijvoorbeeld biomassa als grondstof of voor nieuwe papiersoorten. Daarnaast loopt er onderzoek naar het 3D-printen van voedsel als oplossing voor mondiale voedseltekorten. Maar ook huidige alledaagse producten zijn het resultaat van intensief innovatief werk. Wetenschappers van Unilever in Vlaardingen ontwikkelden Cool Blending, waarmee het mogelijk is om smakelijke margarines te produceren met minder verzadigd vet. Verder ontwikkelden ze een unieke citrusvezeltechnologie waarmee vetarme mayonaise geproduceerd kan worden (Unilever, z.d.). Dit is allemaal slechts een kleine greep uit innovatieprojecten en innovatieve producten, maar het geeft wel aan dat het gaat om veelbelovend onderzoek.

\subsubsection{R\&D agribusiness trekt aan}

In de periode 2014-2016 is het aandeel technologisch innovatieve bedrijven onder de bedrijven met tien of meer werkzame personen ten opzichte van de periode 2012-2014 gestegen met 1 procentpunt, naar 38\%. In de agribusiness is het aandeel innovatoren juist met 5 procentpunt gedaald, naar 36\% (figuur 5.5). Wel is het aandeel bedrijven met gerealiseerde technologische innovaties gestegen, zowel voor alle bedrijven met tien of meer werkzame personen als voor de agribusiness.

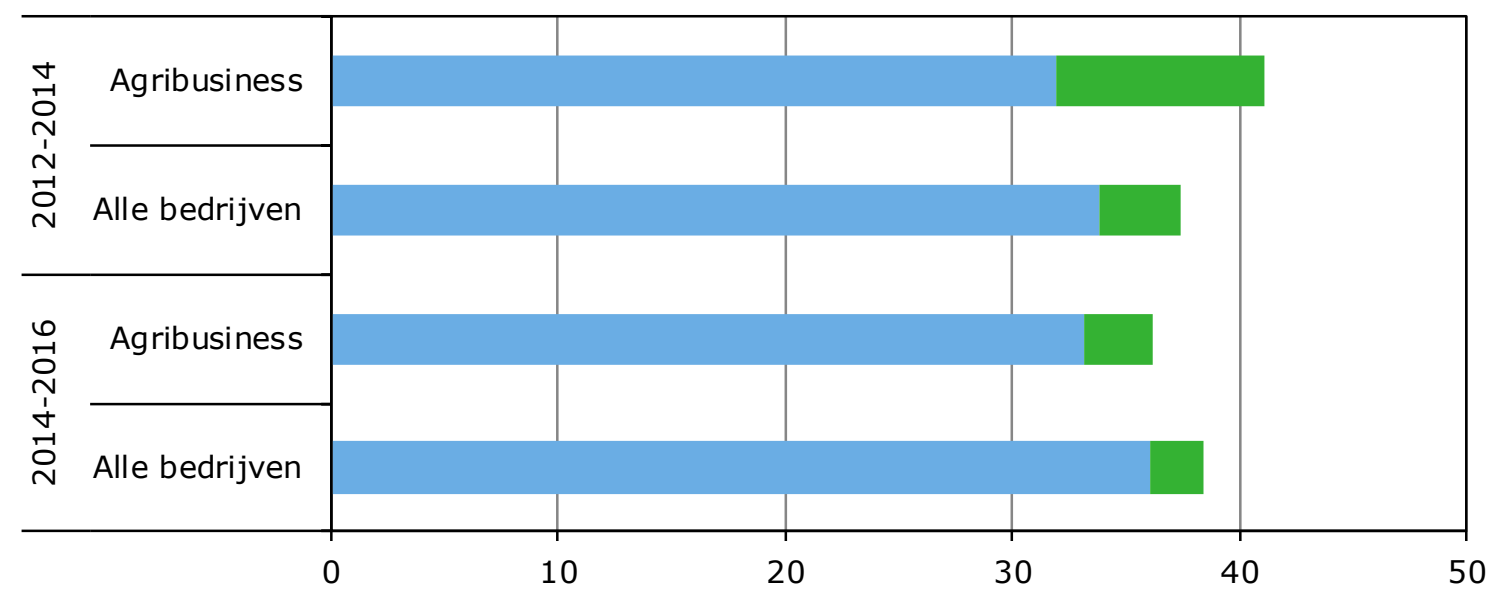

- Voltooide innovaties $\quad$ Onvoltooide of afgebroken innovaties

Figuur 5.5 Aandeel bedrijven met technologische innovaties. Bron: $C B S$. 
In 2016 zijn de R\&D-uitgaven van de agribusiness gestegen, zowel in absolute zin als als aandeel van de technologische innovatie-uitgaven (figuur 5.6 en 5.7). Bedrijven in de agribusiness hebben in 2016 ten opzichte van 2014 meer technologische innovaties voltooid en zijn ook meer gaan uitgeven aan R\&D.

De R\&D-uitgaven van de bedrijven in de agribusiness met tien of meer werkzame personen bedroegen in 2016864 miljoen euro, tegen 728 miljoen euro in 2014. Dit komt neer op een stijging van bijna $19 \%$. De R\&D-uitgaven van bedrijven in Nederland stegen in diezelfde periode bijna $11 \%$.

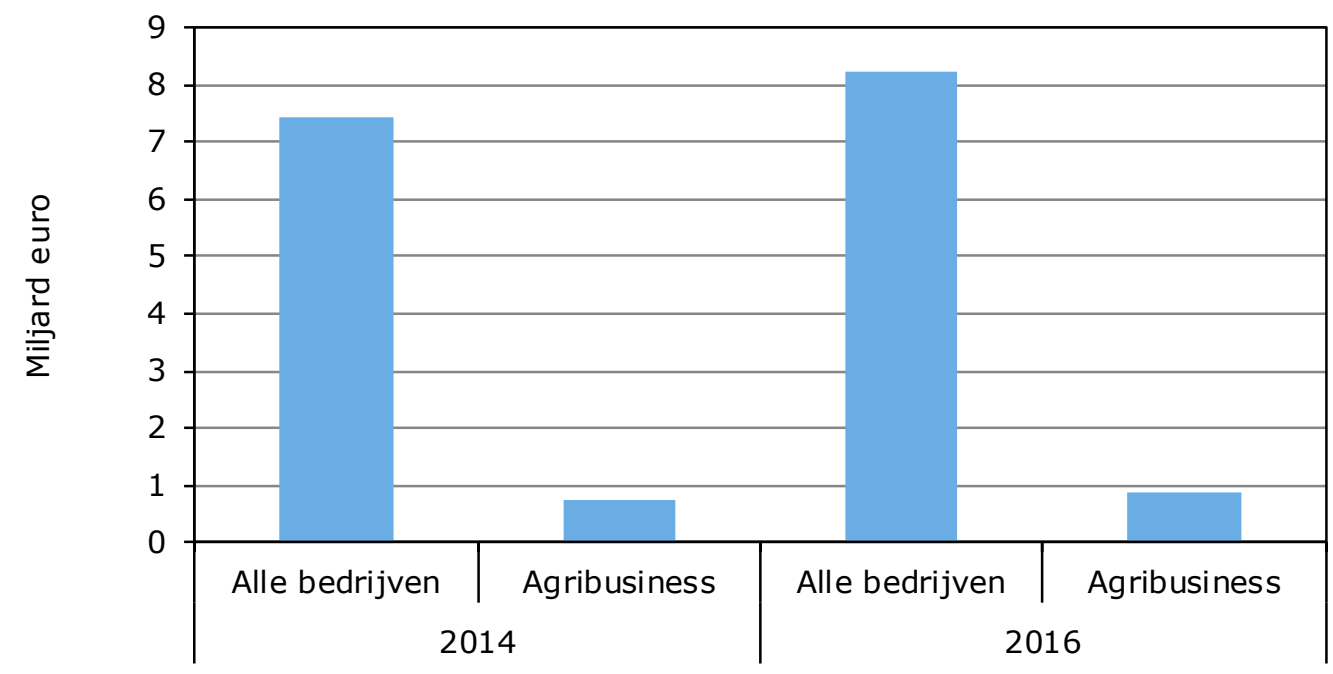

Figuur 5.6 R\&D-uitgaven.

Bron: $C B S$.

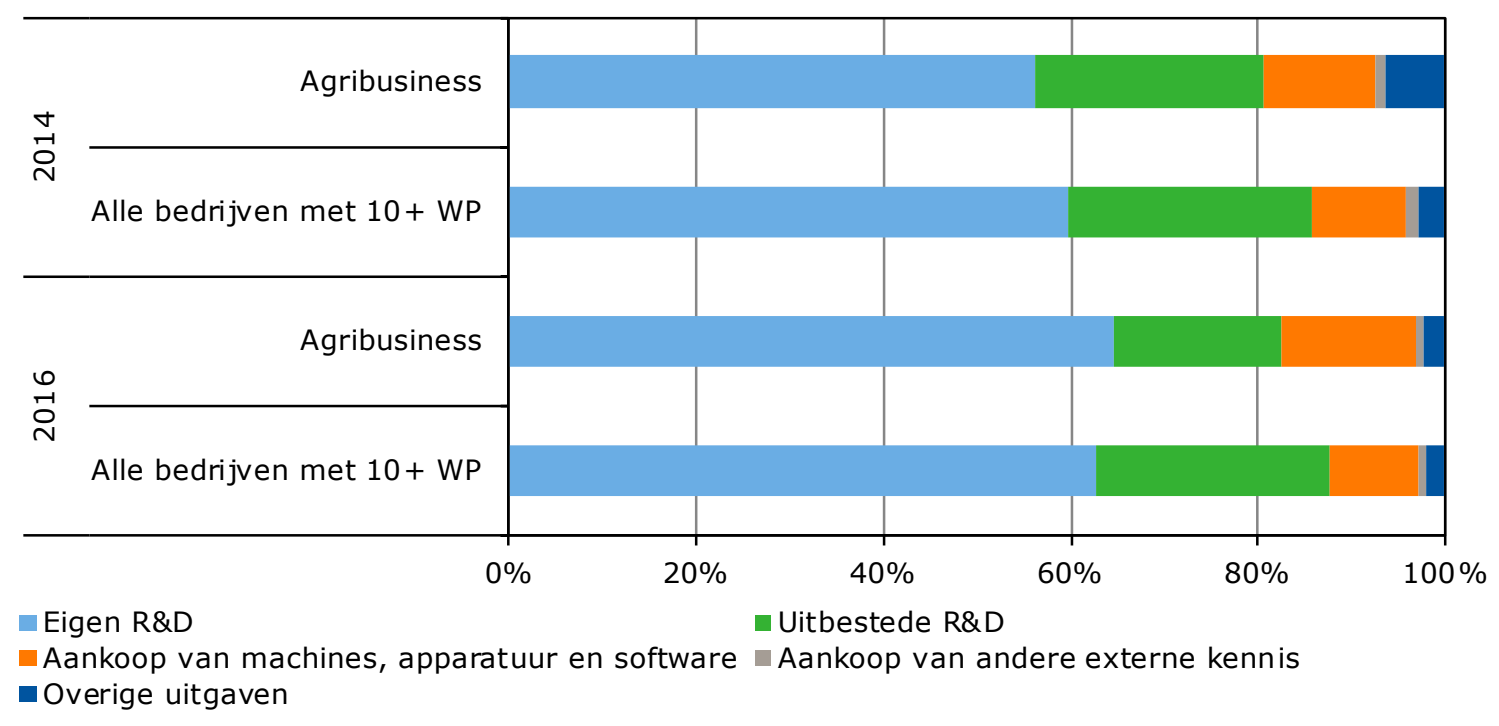

Figuur 5.7 Verdeling innovatie-uitgaven.

Voetnoot: WP: werkzame personen.

Bron: $C B S$.

De agribusiness is niet alleen in absolute zin meer gaan uitgeven aan R\&D, ook in relatieve zin ten opzichte van de totale innovatie-uitgaven is het aandeel R\&D in de agribusiness toegenomen met ruim 8 procentpunt, naar $64,5 \%$. Voor alle bedrijven met tien of meer werkzame personen was dit bescheidener, met 3 procentpunt groei. 


\subsubsection{Percentage productinnovatoren neemt toe}

In de periode 2014-2016 is het aandeel productinnovatoren binnen de populatie van bedrijven met voltooide technologische innovaties gegroeid naar 75\%. Dit aandeel is bij de totale populatie bedrijven met tien of meer werkzame personen iets lager en vrijwel gelijk gebleven (figuur 5.8).

Het omzetaandeel van nieuwe of sterk vernieuwde producten (de innovatieve producten) nam voor de gehele agribusiness in de periode 2014-2016 toe van 10 naar bijna $11 \%$. Productinnovatoren in deze branche zelf zijn daarentegen voor hun eigen omzet minder afhankelijk geworden van innovatieve producten, aangezien hun omzetaandeel daalde van 19 naar $17 \%$.

Productinnovatoren met tien of meer werkzame personen haalden in het algemeen gemiddeld wel meer omzet uit innovatieve producten. Het aandeel innovatieve producten in de totale omzet van bedrijven in Nederland met tien of meer werkzame personen bleef echter vrijwel gelijk.

Uit deze cijfers blijkt dat het belang van productinnovatoren in de agribusiness in de periode 20142016 is toegenomen ten opzichte van 2012-2014. Het aandeel productinnovatoren in het totale aantal technologische innovatoren nam toe, evenals het aandeel van de omzet van innovatieve producten in de totale omzet van de agribusiness. Maar ook voor andere branches in Nederland blijft innovatie een belangrijke aangelegenheid, aangezien bedrijven in Nederland gemiddeld toch voor meer dan $9 \%$ van hun omzet afhankelijk zijn van innovatie.

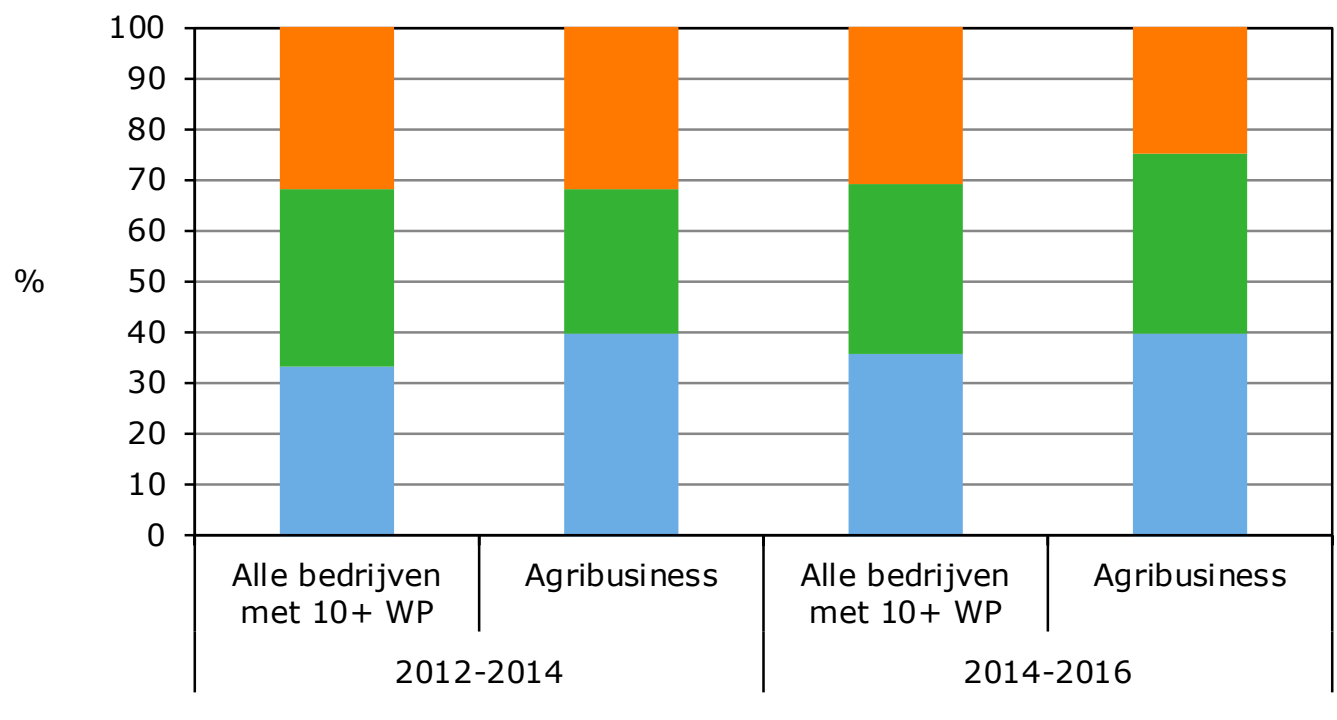

Enkel productinnovatie Beide typen innovaties $\quad$ Enkel procesinnovatie

Figuur 5.8 Type innovatoren.

Voetnoot: WP: werkzame personen.

Bron: CBS. 


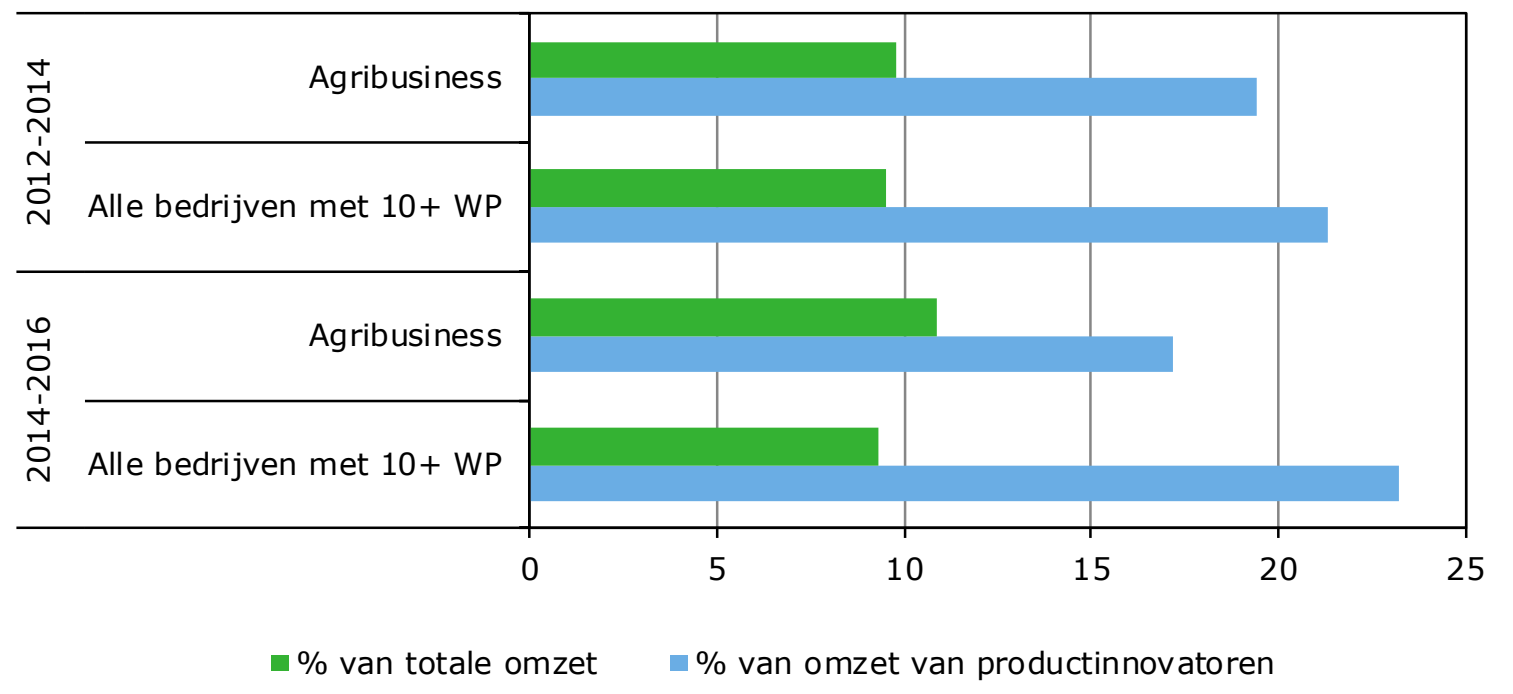

Figuur 5.9 Omzetaandeel nieuwe of sterk vernieuwde producten.

Voetnoog: WP: werkzame personen.

Bron: $C B S$.

\subsection{Patenten stabiele innovatiemotor in voedingsmiddelen- en drankenindustrie}

De voedselindustrie speelt een belangrijke rol in de Nederlandse economie. Het is een industrie die op grote schaal landbouwproducten verwerkt tot voedingsmiddelen en dranken. In 2016 waren er minstens 5.790 bedrijven actief in de drank- en voedselindustrie. Hier werkten 171,7 duizend werknemers, dat is $19,2 \%$ van het totale aantal werknemers in de gehele industrie in Nederland. De voedselindustrie is tevens verantwoordelijk voor circa $22,5 \%$ van de totale omzet in de industrie (zie tabel 5.1). Daarnaast zijn drank- en voedselgerelateerde producten en diensten belangrijk voor de wereldwijde export: zo wordt $21,5 \%$ van de totale industriële export gegenereerd door deze sector.

Tabel 5.1 Kerncijfers drank- en voedingsmiddelenindustrie voor de Nederlandse industrie, 2016.

\begin{tabular}{lrr} 
& Aantallen & Aandeel in totale industrie \\
Bedrijven & 5.790 & 9,5 \\
\hline Werknemers & 171,7 & 19,2 \\
\hline Omzet & 74,0 & 22,5 \\
\hline Toegevoegde waarde & 23,1 & 16,7 \\
\hline Export & 27,0 miljard & 21,5 \\
\hline
\end{tabular}

Bron: European Patent Office (EPO) en CBS.

De Nederlandse voedsel- en drankindustrie wordt zich er ook steeds bewuster van dat een op kennis en ideeën gebaseerde economie belangrijk is voor het behouden van haar vooraanstaande positie. Het creëren van nieuwe ideeën en kennis op zich is echter niet genoeg; bedrijven moeten ervoor zorgen dat de nieuwe kennis en ideeën zowel technisch als economisch waardevol zijn. Om de innovatieve kracht van bedrijven te versterken, wordt er ook veelvuldiger en intensiever samengewerkt met andere bedrijven, klanten, universiteiten, kennisinstellingen enzovoort. In een sector waar veel bedrijven gebonden zijn aan beperkte R\&D-budgetten en technologische middelen, is samenwerking een goede manier om innovatiever te worden. Een voorbeeld van een samenwerking tussen verschillende belanghebbenden is de zogenoemde 'Food Valley' rond Wageningen: een hub van onderzoekscentra en een kennisnetwerk, waar wordt samengewerkt tussen ondernemingen, de overheid en de universiteit. 
Waar kennis is, duikt ook meestal internationalisering op. De internationalisering van innovatieve activiteiten maakt namelijk een belangrijk deel uit van globalisering. Niet alleen industriële processen zijn geglobaliseerd in de vorm van internationale keten- en netwerksamenwerking, ook technologische activiteiten kennen een toenemende mondialisering. Het onderzoek door Breschi en Lissoni (2009) toont bijvoorbeeld aan dat de geografische spreiding van innovatie, gemeten aan de hand van de afstand tussen personen die beschikken over complementaire innovatie, is toegenomen.

In de studie van Powell en Gianella (2010) wordt het thema 'collective inventions' belicht. 'Collective inventions' worden gedefinieerd als 'technology advance driven by knowledge sharing among a community of inventors who are often employed by organizations with competing intellectual property interests'. De rol van patenten, namelijk het verschaffen van exclusieve rechten op een uitvinding, is bij deze definitie van toepassing wanneer men spreekt over intellectueel eigendom. Patenten zijn een veelgebruikte indicator van innovatieoutput (bijvoorbeeld Leten, Belderbos en Van Looy, 2016 en ook CBS, 2017b) en zijn heel sterk gecorreleerd met andere innovatie-indicatoren, zoals de introductie van 'nieuwe producten' (Hagedoorn and Cloodt, 2003).

Naast een heel duidelijke analyse in een historische context en voorbeelden van 'collective inventions' geeft de studie van Powell en Gianella (2010) ook een overzicht van enkele drijfveren van internationale samenwerking:

- Innoveren is risicovol. Door meer samen te werken, worden de risico's en de daaruit volgende kosten van uitvindingen gespreid over meerdere organisaties.

- Bedrijven die zich internationaal willen profileren en daarvoor toegang willen krijgen tot geografisch gelokaliseerde kennis, kunnen dit verkrijgen door deel te nemen aan collectieve uitvindingen met uitvinders in het buitenland.

- Aangezien kennis steeds sneller verouderd is, zijn bedrijven ook meer en meer genoodzaakt om toegang te krijgen tot de meest recente expertise over grenzen heen.

\subsubsection{Internationalisering en samenwerking}

Het onderzoek in dit hoofdstuk gaat over internationalisering en samenwerking bij innovatie in de voedsel- en drankindustrie. Er zijn patentdata gebruikt om internationale samenwerking in innovatie te meten. Vanuit de patentdocumentatie is het mogelijk om namen en adressen van zowel de aanvrager als de uitvinder(s) van het patent te identificeren. Hierdoor kan worden nagegaan waar die uitvinders zijn gelokaliseerd en kan de informatie over uitvinders gebruikt worden om de grootte van een mogelijk onderzoeksteam en de geografische ligging van uitvinders te bepalen. Om beter te begrijpen hoe het innovatieproces is geïnternationaliseerd, kan worden nagegaan in hoeverre uitvinders met buitenlandse adressen betrokken zijn bij een patent, dus, of er al dan niet internationale samenwerking bij uitvindingen bestaat. In internationaal vergelijkend onderzoek van Nagaoka et al. (2010) is de evolutie te zien van het aantal patenten met internationale co-uitvinders tussen de periode 1980-2005 voor Japan, de Verenigde Staten, Duitsland, Frankrijk en het Verenigd Koninkrijk. Uit de cijfers blijkt dat het aandeel van door co-uitvindingen gerealiseerde patenten gedurende de onderzochte periode is toegenomen en een klein aandeel van alle aangevraagde patenten vertegenwoordigt ( $2 \%$ in Japan, $8 \%$ in de Verenigde Staten, $9 \%$ in Duitsland en Frankrijk en $12 \%$ in het Verenigd Koninkrijk). Vervolgens tonen de auteurs aan dat een team van internationale co-uitvinders groter is dan een team van lokale uitvinders. Een internationaal team bestaat uit ongeveer vier internationale co-uitvinders, afkomstig uit drie landen.

Buitenlandse bedrijven die in Nederland investeren, brengen dikwijls technologische vaardigheden en een internationaal kennisnetwerk met zich mee. Dit kan weer aanleiding geven tot kennisoverdracht en andere vormen van 'spillovers' naar lokale ondernemingen toe. Bijvoorbeeld: uit het onderzoek van Fons-Rosen et al. (2018) blijkt dat de aanwezigheid van ondernemingen met buitenlandse zeggenschap horizontale 'kennis-spillovers' naar lokale bedrijven genereert wanneer beide bedrijven (i) in dezelfde sector operationeel zijn en (ii) over een gelijkaardige technologische kennis ('technological closeness') beschikken. De gelijkaardige technologische kennis werd in deze bovengenoemde studie gemeten aan de hand van patentclassificaties; spillovers werden gemeten aan de hand van de mobiliteit van uitvinders tussen buiten- en binnenlandse ondernemingen. Op basis van 
de patentdata is ook de informatie van de aanvrager beschikbaar. Alleen aan aanvragers die als bedrijf kunnen worden gezien, kunnen gegevens over buitenlandse zeggenschap worden gekoppeld.

\subsubsection{Registratie patentaanvragen}

Voor de periode 2000-2013 zijn patentaanvragen verzameld op het niveau van de ondernemingengroep. Dit omdat het eigendomsrecht van intellectuele eigendom op dit niveau van toepassing is en niet toe te wijzen is aan individuele bedrijven binnen de groep. Ook is het zo dat aanvragers van patenten die een beroep doen op naam van het individuele bedrijf binnen de groep of op niveau van de ondernemingsgroep soms moeilijk te onderscheiden zijn. Alle Nederlandse en Europese patentaanvragen die in de periode 2000-2013 zijn geregistreerd bij het European Patent Office (EPO), zijn opgenomen in de analyse. Er is gewerkt met alle ondernemingen die ten minste één aanvraag in Nederland hebben ingediend en de dataset bevat, naast de naam van de aanvrager van het patent, het jaar waarin de aanvraag werd ingediend, de internationale patentclassificatie, waarmee wordt aangegeven in welk technologisch toepassingsgebied een bepaalde uitvinding zich bevindt (de classificatie is terug te vinden op de website), de uitvindersnaam en -residentie, de bijbehorende statistische eenheid van de ondernemingsgroep en informatie over buitenlandse zeggenschap. Ondernemingen zijn vervolgens volgens de Standaard Bedrijfsindeling (SBI) op basis van een 2 cijfer niveau naar bedrijfstak ingedeeld. De data over buitenlandse zeggenschap zijn afkomstig uit de 'Foreign Affiliate Statistics' (FATS) en zijn beschikbaar vanaf 2006. Op basis hiervan is een onderscheid gemaakt tussen buitenlandse en Nederlandse zeggenschap.

Patentactieve bedrijven die tot de voedsel- en drankindustrie behoren, zijn aan de hand van twee methoden geselecteerd. In de eerste methode is een selectie gemaakt van alle bedrijven op basis van hun economische hoofdactiviteit volgens de SBI2008-code 10-11 (de voedings- en drankenindustrie volgens de SBI). Als referentiekader wordt ook gekeken naar evoluties van patentactieve bedrijven die volgens SBI2008-code 10-33 tot de gehele industrie behoren. Bedrijven die buiten de hoofdactiviteit 10-11 vallen, dienen echter ook patentaanvragen in die gerelateerd zijn aan de technologie in het domein van voedsel en drank. Om deze bedrijven ook op te nemen in de analyse, wordt ook de zogenoemde 'International Patent Classification' (IPC), een classificatie van technologisch gebieden waaraan een bepaald patent gerelateerd is, meegenomen. De technologische gebieden waar de voedselindustrie toe behoort, zijn: baking, equipment for making or processing doughs, doughs for baking, butchering; meat treatment; processing poultry or fish foods en foodstuffs.

\subsubsection{Herstel aantal patentaanvragen}

In figuur 5.10 wordt de evolutie weergegeven van het aantal aangevraagde EPO-patenten voor de gehele industrie (SBI10-33). We zien dat het aantal patenten voor de gehele industrie vooral tussen 2000 en 2003 sterk steeg, van 2.902 naar 3.730 patenten. Tussen 2007 en 2010, tijdens de crisisjaren, daalde het aantal aanvragen flink tot 2.372 patenten. Daarna zien we weer een stijging tot 2.881 aangevraagde patenten in 2013. Hieruit kunnen we dus concluderen dat er op het vlak van uitvindingen een herstel merkbaar is na de financiële crisis. 


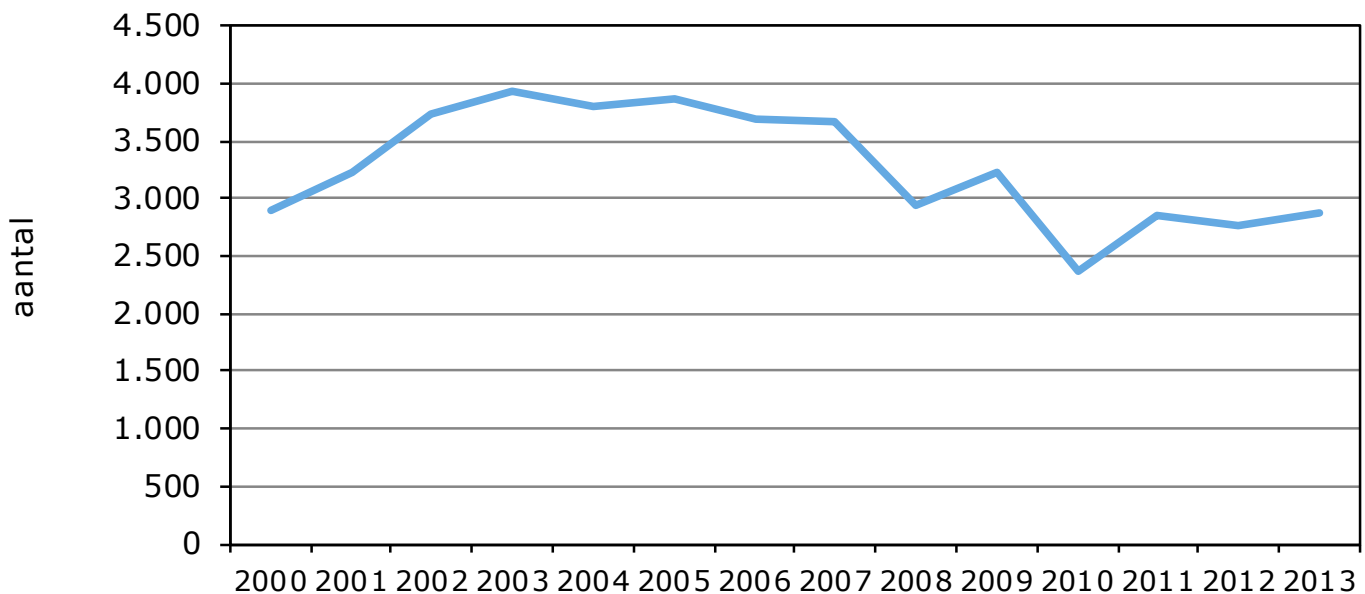

Figuur 5.10 Aantal aangevraagde patenten, industrie, 2000-2013. Bron: European Patent Office (EPO) en CBS.

In figuur 5.11 kijken we zowel naar de evolutie van het aantal aangevraagde patenten in de drank- en voedselindustrie (SBI 10-11) als naar sectoren waarin bedrijven patenten op het technologiegebied voedsel hebben aangevraagd (IPC). Uit de figuur blijkt duidelijk dat het aantal aangevraagde patenten met IPC 'voedsel' gedurende de gehele periode is toegenomen. Het aantal aangevraagde patenten volgens bedrijfsactiviteit daarentegen fluctueert sterk, met een dieptepunt in zowel 2004 als 2010.

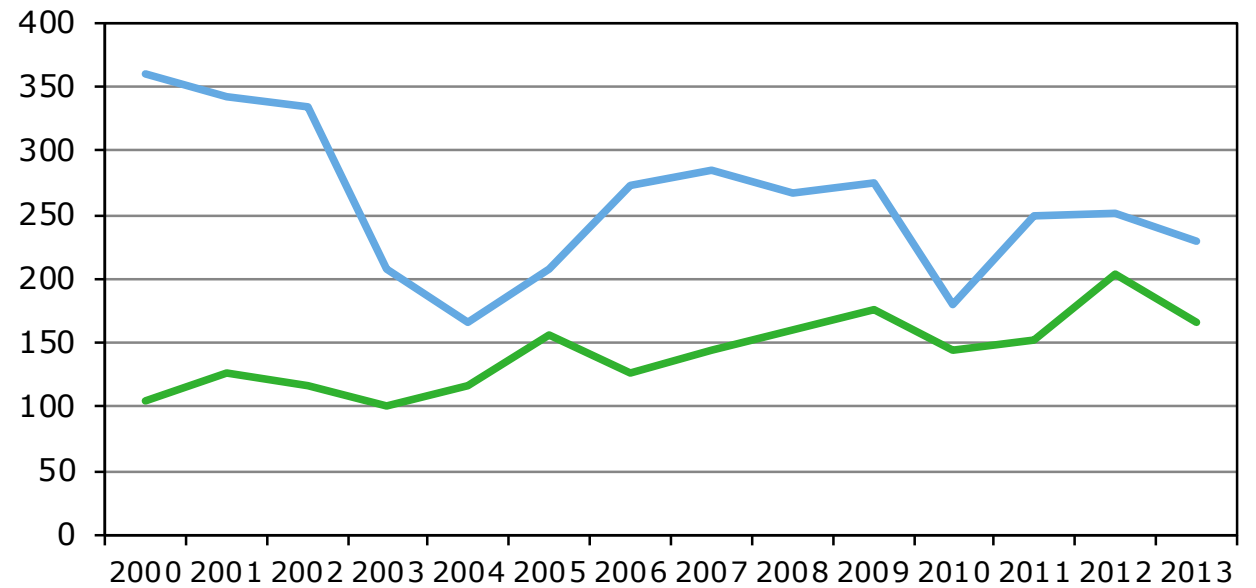

Aantal patenten, SBI10-11 $\longrightarrow$ Aantal patenten, IPC

Figuur 5.11 Aantal aangevraagde patenten SBI10-11, IPC voedsel, 2000-2013. Bron: European Patent Office (EPO) en CBS.

In figuur 5.12 (gehele industrie) en 5.13 (voeding en dranken) is de evolutie weergegeven van het aantal patenten met één of meerdere buitenlandse uitvinders en het aantal patenten met alleen lokale uitvinders. Uit figuur 5.13 blijkt dat in de drank- en voedselindustrie patenten voornamelijk worden gerealiseerd in samenwerking met buitenlandse uitvinders. Uit de figuur blijkt ook heel duidelijk dat er rond 2002 een plotselinge snelle afname is van het aantal patenten dat gerealiseerd is in samenwerking met buitenlandse uitvinders en een lichte daling na de crisis van 2008 in de drank- en voedselindustrie. Het aantal aangevraagde patenten van alleen lokale uitvinders is gedurende de hele periode 2000-2013 relatief stabiel gebleven. In de gehele industrie (figuur 5.12) zijn er gedurende 
vrijwel de hele periode meer patenten aangevraagd door alleen Nederlandse uitvinders dan in samenwerking met buitenlandse uitvinders.

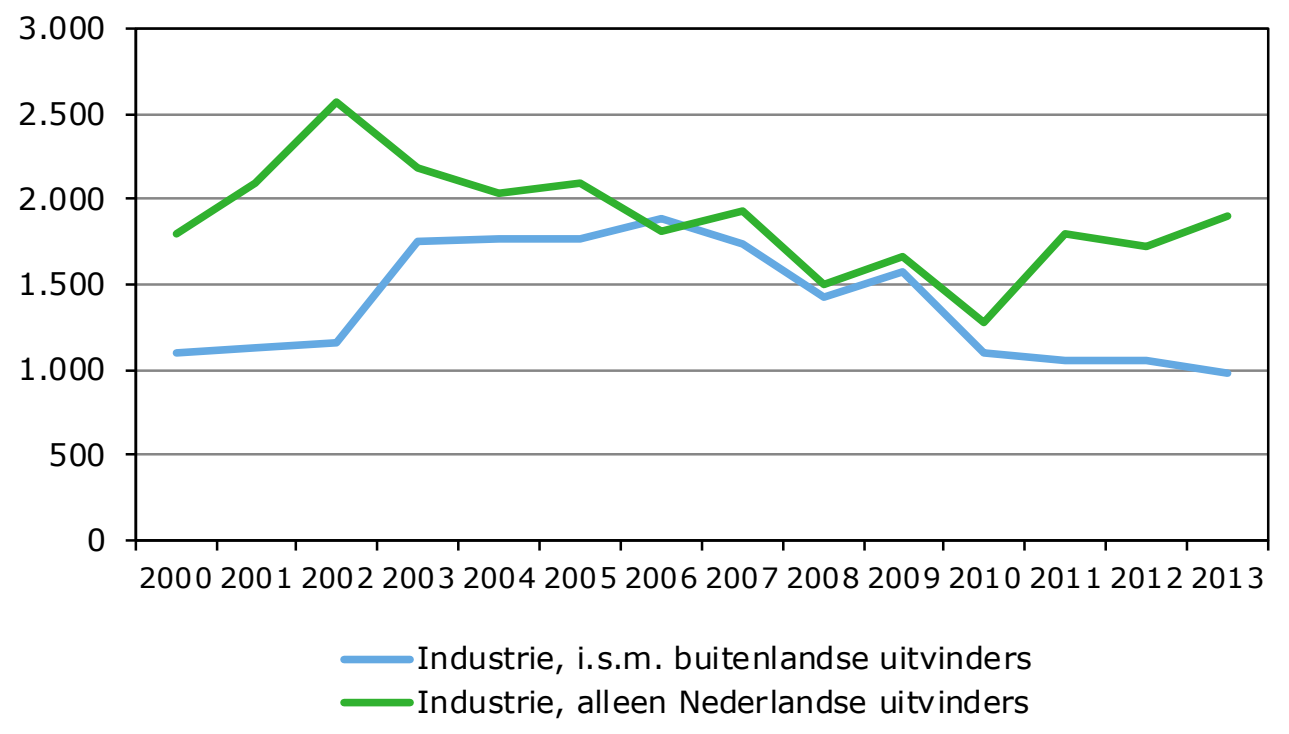

Figuur 5.12 Aantal aangevraagde patenten in totale industrie (SBI 10-33) volgens typering uitvinder, lokaal versus buitenlands, 2000-2013.

Bron: European Patent Office (EPO) en CBS.

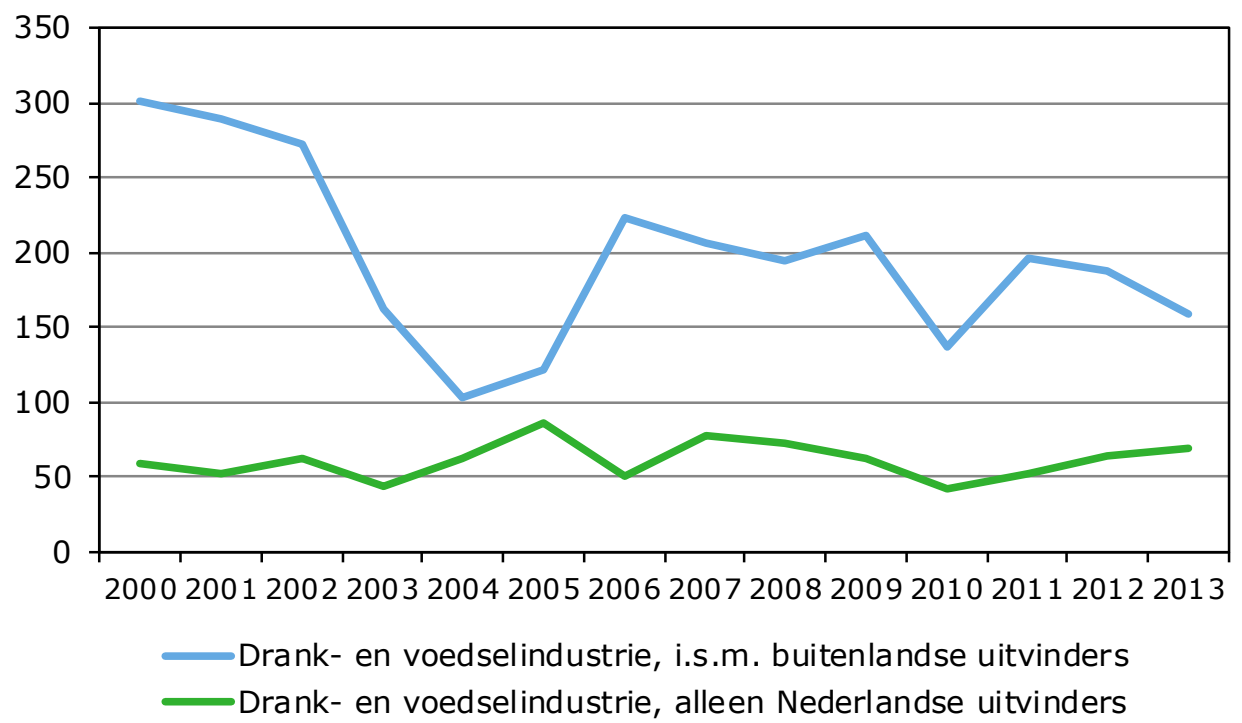

Figuur 5.13 Aantal aangevraagde patenten in drank- en voedselindustrie (SBI 10-11) volgens typering uitvinder, lokaal versus buitenlands, 2000-2013.

Bron: European Patent Office (EPO) en CBS.

Met internationalisering van innovatie wordt in deze studie niet alleen verwezen naar buitenlandse uitvinders, maar ook naar buitenlands eigenaarschap van bedrijven die actief zijn in het verwerven van patenten. Algemeen wordt aangenomen dat buitenlandse bedrijven, dus bedrijven die deel uitmaken van een buitenlands concern, kennisspillovers hebben naar lokale bedrijven. Uit tabel 5.2 blijkt dat gedurende de onderzoeksperiode 2006-2013 het aantal buitenlandse patentactieve bedrijven in de drank- en voedselindustrie en bedrijven die gerelateerd zijn aan voedseltechnologie stabiel is gebleven, terwijl de algemene trend van buitenlandse bedrijven in de totale industrie eerder stijgend is. In de cijfers valt ook op dat in elk van de categorieën het aantal buitenlandse patentactieve bedrijven in het crisisjaar 2008 niet drastisch is teruggelopen. De resultaten in tabel 5.2 vormen een 
sterke aanwijzing dat gedurende de hele periode inkomende buitenlandse investeringen en de rol van internationale samenwerking relatief stabiel zijn gebleven. Dit kan deels ook worden verklaard door de eventuele steunpakketten waarin de overheid voorziet (bijvoorbeeld door middel van de innovatiebox en R\&D-subsidies).

Tabel 5.2 Aantal bedrijven, lokaal versus buitenlands, 2006-2013.

\begin{tabular}{|c|c|c|c|c|c|c|}
\hline \multirow[t]{2}{*}{ Jaar } & \multicolumn{2}{|c|}{ Drank- en voedselindustrie } & \multicolumn{2}{|c|}{ IPC } & \multicolumn{2}{|c|}{ Gehele industrie } \\
\hline & NL & BUIT & NL & BUIT & NL & BUIT \\
\hline 2006 & 8 & 4 & 28 & 5 & 215 & 62 \\
\hline 2008 & 8 & 3 & 26 & 5 & 211 & 81 \\
\hline 2009 & 11 & 5 & 34 & 8 & 212 & 68 \\
\hline 2011 & 10 & 5 & 31 & 6 & 196 & 84 \\
\hline 2012 & 13 & 3 & 37 & 9 & 190 & 81 \\
\hline 2013 & 17 & 3 & 33 & 8 & 209 & 84 \\
\hline
\end{tabular}

Bron: European Patent Office (EPO) en CBS.

\subsubsection{Effect conjunctuur}

Innovatie, internationalisering en samenwerking worden gezien als belangrijke drijfveren achter economische groei. De resultaten van dit onderzoek, afgeleid uit patentdata om internationale samenwerking in innovatie te analyseren, wijzen erop dat het aantal aangevraagde patenten waarbij buitenlandse uitvinders actief betrokken zijn sterker varieert vergeleken met het aantal patenten dat gerealiseerd is door alleen lokale uitvinders. Het aantal patenten met alleen lokale uitvinders blijft in de periode 2000-2013 namelijk relatief stabiel, terwijl de overige uitvindingen in aantal fluctueren en gemiddeld genomen een dalende trend vertonen.

Deze resultaten zijn deels in overeenstemming met vorig CBS-onderzoek (zie Schoonbrood en Vancauteren, 2015), waarin werd aangetoond dat de ontwikkeling van innovatie-uitgaven door bedrijven met een buitenlands moederbedrijf in de periode 2008-2012 sterk afnamen.

Wanneer wordt gezocht naar redenen van een grotere volatiliteit van buitenlandse uitvinders die bijgedragen hebben aan patenten, zien we heel duidelijk een hele sterke samenhang tussen schokken in de economie en de inzet van internationale samenwerking in innovatie. Voor bedrijven die al dan niet in buitenlandse handen zijn, is die samenhang minder zichtbaar. Dit zou erop kunnen wijzen dat buitenlandse investeringen in de sector vaste kosten met zich meebrengen en dat, wanneer de economische toestand onzeker wordt, er vooral wordt ingezet op lokale kennis. 


\subsection{5 dochterondernemingen van voeding en drank buiten EU}

In 2016 hadden Nederlandse bedrijven 225 dochterondernemingen in de dranken- en voedingsmiddelenindustrie buiten de Europese Unie. Dat is een kleine toename na een aantal jaren waarin het aantal bedrijven flink afnam. In 2012 waren er nog er nog 335 bedrijven in de dranken- en voedingsmiddelenindustrie. Van 2014 op 2015 was sprake van een daling van 55 bedrijven, bijna allemaal in de voedingsmiddelenindustrie. De daling werd vooral veroorzaakt door Canada ( -15 bedrijven) en landen in het Verre Oosten (-20). Zie figuur 5.14.

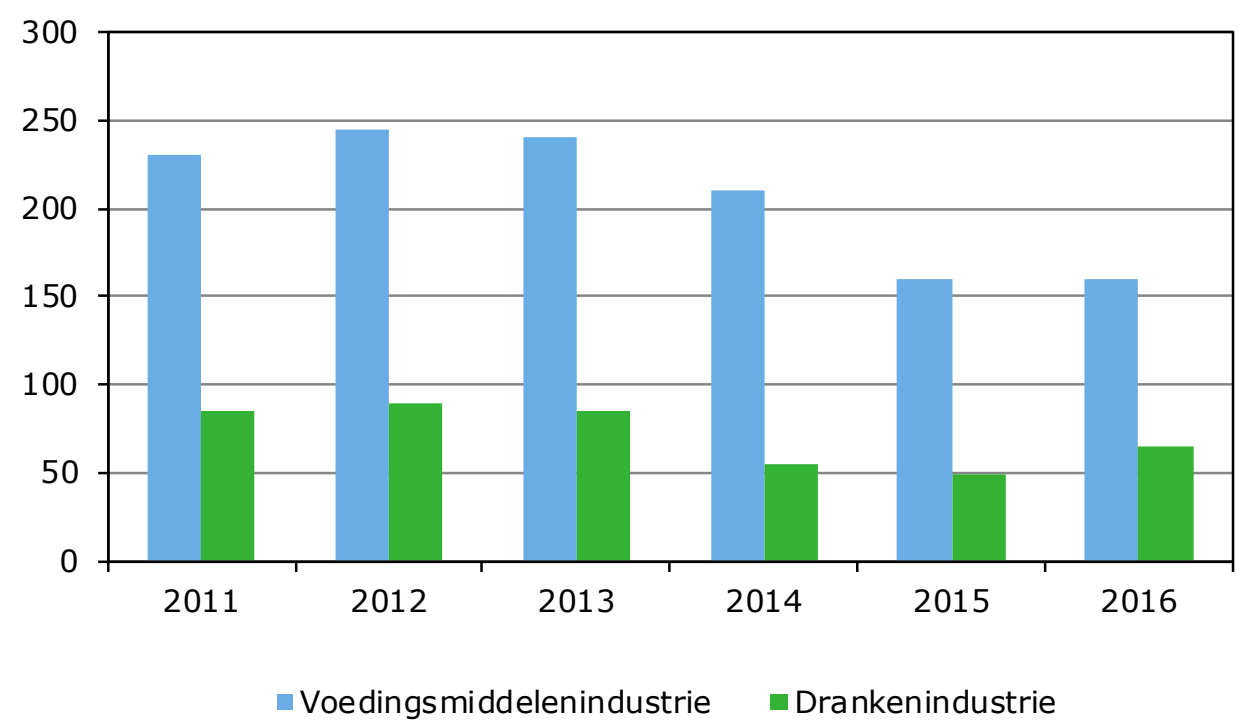

Figuur 5.14 Aantallen Nederlandse dochterondernemingen buiten de EU, 2011-2016. Bron: CBS, Eurostat.

In 2016 nam het aantal voedingsmiddelenbedrijven niet verder af. Het aantal bedrijven in de drankenindustrie nam met 5 licht toe, vooral veroorzaakt door een toename van 15 Zwitserse dochterbedrijven.

De belangrijkste vestigingslanden voor Nederland waren in de jaren vanaf 2011 de Verenigde Staten, China en Canada. Vanaf 2015 is Canada uit deze top drie weggevallen - in 2016 heeft Zwitserland deze plek ingenomen. Het belang van de oorspronkelijke top drie van vestigingslanden is in de periode 2011-2016 wel minder geworden. Het totaal aan bedrijven is in deze landen gedaald van 105 naar 50 en het aandeel van de top drie in het totaal van een derde tot minder dan een kwart. 


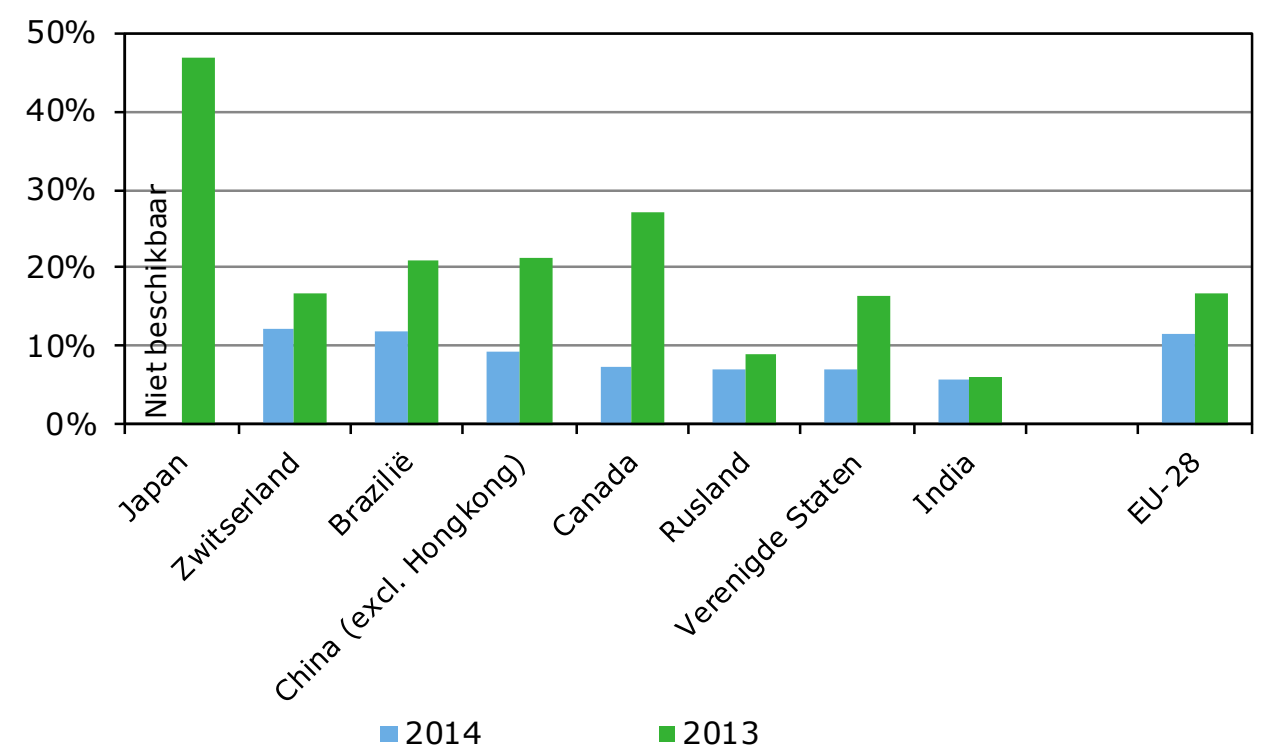

Figuur 5.15 Aandeel Nederland in aantal EU-dochterondernemingen buiten de EU t.a.v. de voedingsmiddelen-, dranken- en tabaksindustrie.

Bron: CBS, Eurostat.

Alle EU-landen samen hadden in 2014 ruim 2.300 dochterondernemingen in de voedingsmiddelen-, dranken- en tabaksindustrie buiten de EU. De belangrijkste bestemmingen zijn de Verenigde Staten (374 in 2015), China (172), Rusland (113), Brazilië (108) en Canada (67).

Nederland was in 2014 nog steeds een belangrijke Europese speler en was ook het op twee na belangrijkste EU-land wat betreft het aantal nationale ondernemingen buiten de EU. Alleen Frankrijk (701) en het Verenigd Koninkrijk (631) hadden er meer. Wel is de afstand tot die twee landen groter geworden. Het aantal Nederlandse bedrijven daalde, terwijl in de beide andere landen er sprake was van een toename van het aantal bedrijven. Het aantal steeg in Frankrijk met 100 en in het Verenigd Koninkrijk met 265, wat bijna een verdubbeling is. Die prestatie werd in 2015 herhaald, toen steeg het aantal buitenlandse dochterondernemingen van het Verenigd Koninkrijk met bijna 500.

Om een idee te krijgen op welke landen de Nederlandse dranken en voedingsmiddelenindustrie bij uitstek gericht is, is het nuttig om het Nederlandse aandeel per land te berekenen op basis van de EUtotalen. In verband met geheimhouding zijn de percentages alleen beschikbaar voor de belangrijkste bestemmingen. Bovendien zijn niet voor alle jaren alle gegevens beschikbaar ${ }^{8}$.

Zwitserland en Brazilië zijn landen waar Nederland in 2014 relatief veel dranken- en voedingsmiddelenindustrie vestigde. In 2013 was dat ook zeker Japan, maar in 2014 en 2015 waren daarvoor geen EU-totalen beschikbaar. Van de landen waarvan de gegevens beschikbaar zijn, was er in 2014 geen duidelijk land waar Nederland zich bovengemiddeld vaak op richtte.

Voor alle landen waarvan gegevens beschikbaar zijn, is het aandeel van de Nederlandse dochterondernemingen gedaald, het sterkst in Canada. Dat vertaalt zich ook in een daling van het aandeel Nederlandse ondernemingen in het totaal van alle EU-ondernemingen met een dochteronderneming buiten de EU. Dat is gedaald van 1 op de 6 in 2013 tot 1 op de 10 in 2014.

\subsubsection{3 buitenlandse dochterbedrijven actief in Nederland}

In 2016 waren er in de Nederlandse voedingsmiddelen-en drankindustrie 6.400 bedrijven actief. Daarvan hadden er 183 bedrijven een buitenlandse moedermaatschappij. In vergelijking met 2007 was zowel het aantal buitenlandse bedrijven als het aantal Nederlandse bedrijven in deze branche met

8 Voor Zwitserland en de VS en Canada zijn de verhoudingen van 2015 gebruikt, voor Zwitserland zijn voor de gegevens uit 2013 die van 2011 gebruikt, voor China die van 2010. 
een kwart toegenomen, mogelijk deels door schaalverkleining. De toename van buitenlandse bedrijven was het grootst bij de grotere bedrijven: in 2016 was de helft van de allergrootste bedrijven (250 of meer werkzame personen) in buitenlandse handen, in 2007 was dat nog iets meer dan een derde. Van de grootste MKB-bedrijven (50-249 werkzame personen) was in 2016 bijna 1 op de 4 bedrijven buitenlands, in 2007 was dat nog 1 op de 8 . De toename van het aantal grotere buitenlandse bedrijven is ook zichtbaar in het aandeel werknemers dat werkzaam was voor een dochteronderneming van een buitenlands moederbedrijf. In de periode 2007-2016 was dat gestegen van $20 \%$ naar $25 \%$.

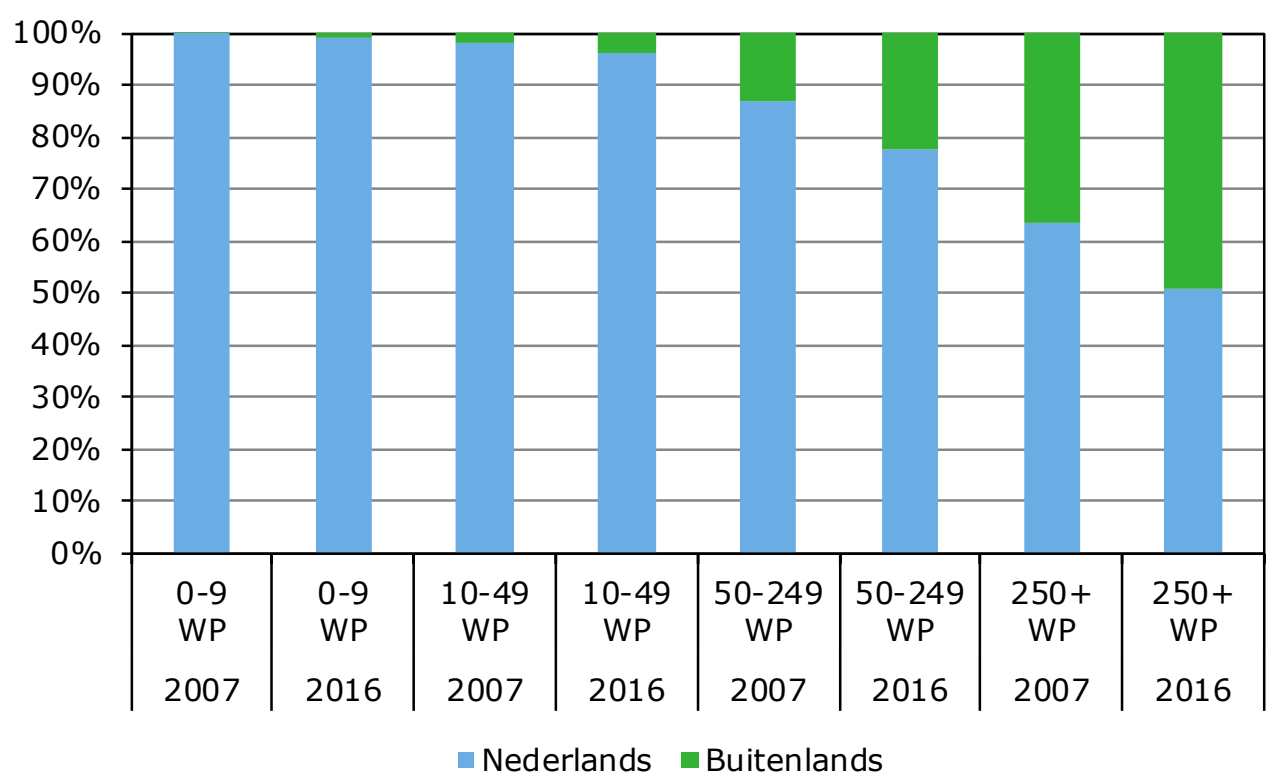

Figuur 5.16 Aantallen bedrijven naar bedrijfsgrootte en buitenlands eigendom.

Voetnoot: WP: werkzame personen.

Bron: CBS.

\section{Vestigingsland moederbedrijf}

De grootste groep buitenlandse bedrijven had in 2016 een moedermaatschappij die gevestigd was binnen de eurozone, gevolgd door bedrijven met een moedermaatschappij in Noord-Amerika. Samen waren deze regio's goed voor twee derde van alle buitenlandse dochterondernemingen. Het aantal bedrijven met een moederbedrijf in Oost- of Zuidoost-Azië was weliswaar beperkt - met net minder dan 20 bedrijven - maar is sinds 2007 wel ruim verdubbeld.

\section{Bedrijven met buitenlandse moedermaatschappij vaker actief als handelaar in goederen}

Bedrijven met een buitenlandse moedermaatschappij doen vaker aan goederenhandel met het buitenland dan bedrijven in Nederlandse handen. In 2007 was slechts $8 \%$ van de bedrijven met een buitenlandse moedermaatschappij niet actief als importeur of exporteur van goederen. Voor Nederlandse bedrijven lag dat op 77\%. In beide groepen is het aandeel handelaren in 2016 licht gestegen. De Nederlandse bedrijven zijn vooral vaker gaan importeren.

Als een buitenlands bedrijf handel drijft, is dat in meer dan $90 \%$ van de gevallen als 'two-way-trader': een bedrijf dat zowel exporteert als importeert. Voor Nederlandse bedrijven is dat bij minder dan de helft van de handelende bedrijven het geval.

De ongeveer $3 \%$ van de bedrijven in de voedingsmiddelen en drankindustrie die in buitenlandse handen zijn, zijn goed voor ongeveer $40 \%$ van de totale exportwaarde van die branche en voor $60 \%$ van de importwaarde. De groep buitenlandse bedrijven heeft in de periode 2007-2016 een groei van $15 \%$ van de export en $12 \%$ importgroei laten zien. Voor Nederlandse bedrijven lag dat op respectievelijk $10 \%$ en $1 \%$. 


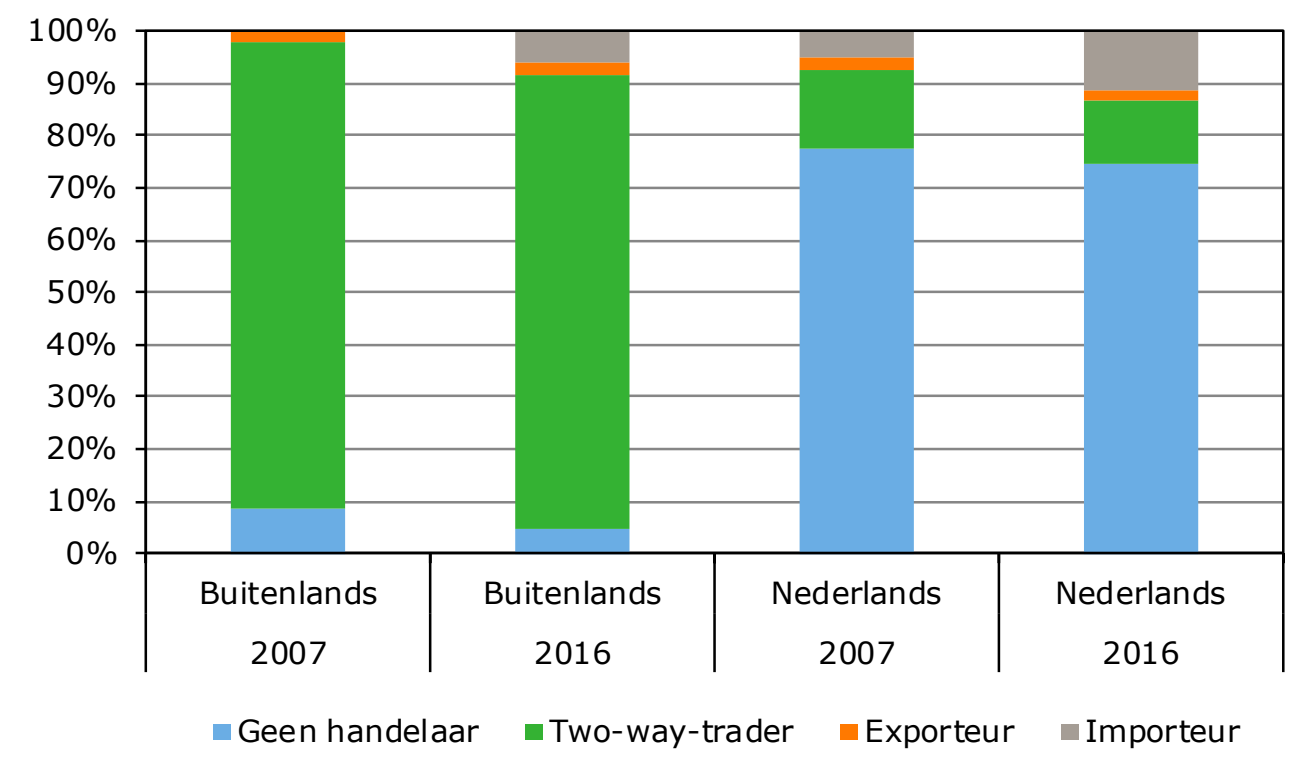

Figuur 5.17 Handelaarstype en buitenlands eigendom.

Bron: $C B S$.

\section{Buitenlandse bedrijven exporteren naar meer landen}

Gemiddeld genomen exporteert een bedrijf in buitenlandse handen naar 30 landen en een Nederlands bedrijf naar 12. Ook wanneer naar continenten wordt gekeken, wordt duidelijk dat bedrijven in buitenlandse handen een grotere regionale spreiding hebben van hun goederenhandel. Ruim een kwart van de buitenlandse bedrijven is als exporteur actief op alle vijf de continenten, bij Nederlandse bedrijven is dat minder dan $10 \%$. Daarentegen is iets meer dan de helft van de Nederlandse bedrijven actief op slechts één continent. Dat is in bijna alle gevallen Europa, met het zwaartepunt in de eurozone. De buitenlandse exporteurs die op één continent actief zijn, zijn allemaal uitsluitend actief in Europa, met een minder sterke focus op de eurozone.

Van de 183 bedrijven in buitenlands eigendom handelen er in 2016145 met het land waar het moederbedrijf is gevestigd. Voor bijna 50 daarvan vertegenwoordigt de handel met dat moederland ten minste $50 \%$ van de totale export- of importwaarde.

De vier belangrijkste exportlanden zijn, afgezien van de volgorde, voor de Nederlandse en buitenlandse bedrijven identiek: Duitsland, Engeland, België en Frankrijk. De top vijf wordt voor de Nederlandse bedrijven aangevuld met Italië en voor de buitenlandse bedrijven met China.

\section{Buitenlandse bedrijven exporteren veel chocolade en cacao}

De belangrijkste vijf exportproducten in 2016 zijn voor buitenlandse bedrijven cacao, chocolade, bereide voedingsmiddelen, natuurlijke oliën of vetten en granen. Voor Nederlandse bedrijven zijn dat vlees (rund, ander vlees en slachtafval), bereide voedingsmiddelen, groenten en kaas en wrongel.

\subsection{Relatief veel internationale landbouwalumni verlaten Nederland}

In deze paragraaf zal worden gekeken naar het carrièreverloop van internationale wo-alumni in Nederland met een specifieke focus op landbouwstudenten aan de universiteit Wageningen (zie ook CBS: 2017c, 2018d en 2018e).

In het studiejaar 2009/2010 studeerden 7.149 internationale studenten af aan Nederlandse universiteiten. Daarvan hebben 5.451 studenten zich op enig moment ingeschreven bij een Nederlandse gemeente. Deze groep kan door de tijd worden gevolgd wat betreft hun woon- en werksituatie. Zo is te herleiden dat $68 \%$ van de geregistreerden enkele maanden later nog was 
ingeschreven in Nederland (32\% vertrokken). Dat percentage loopt terug tot 44\% (1 oktober 2012) en $35 \%$ ( 1 oktober 2014). In dat licht moet ook worden gekeken naar het aantal in Nederland werkzame internationale alumni. Dat percentage was op 1 oktober 2010 24\%, liep op naar 27\% in 2012 (meer werkvinders dan alumni die uit Nederland vertrokken) en weer terug naar 24\% (meer alumni die uit Nederland vertrokken dan werkvinders).

Voor specifiek Wageningen zijn dezelfde patronen zichtbaar, maar liggen de percentages over de gehele linie een stuk lager. Daar zit deels een logica in, omdat alumni die Nederland hebben verlaten, uiteraard ook niet in Nederland werkzaam kunnen zijn. Desalniettemin valt het aantal internationale alumni van de universiteit Wageningen dat vertrekt op. Het percentage ingeschrevenen was op 1 oktober 2010 67\% (van 391 ingeschreven afgestudeerden) en daalt sterk naar 35\% (2012) en 24\% (2014). Het aantal werkenden gaat van $16 \%$ omhoog naar $19 \%$ en weer terug naar $15 \%$. Daar komt bij dat voor elk gemeten jaar onder Wageningse internationale alumni het aantal werkenden in verhouding tot het aantal ingeschrevenen lager ligt in vergelijking met het totaal internationale alumni.

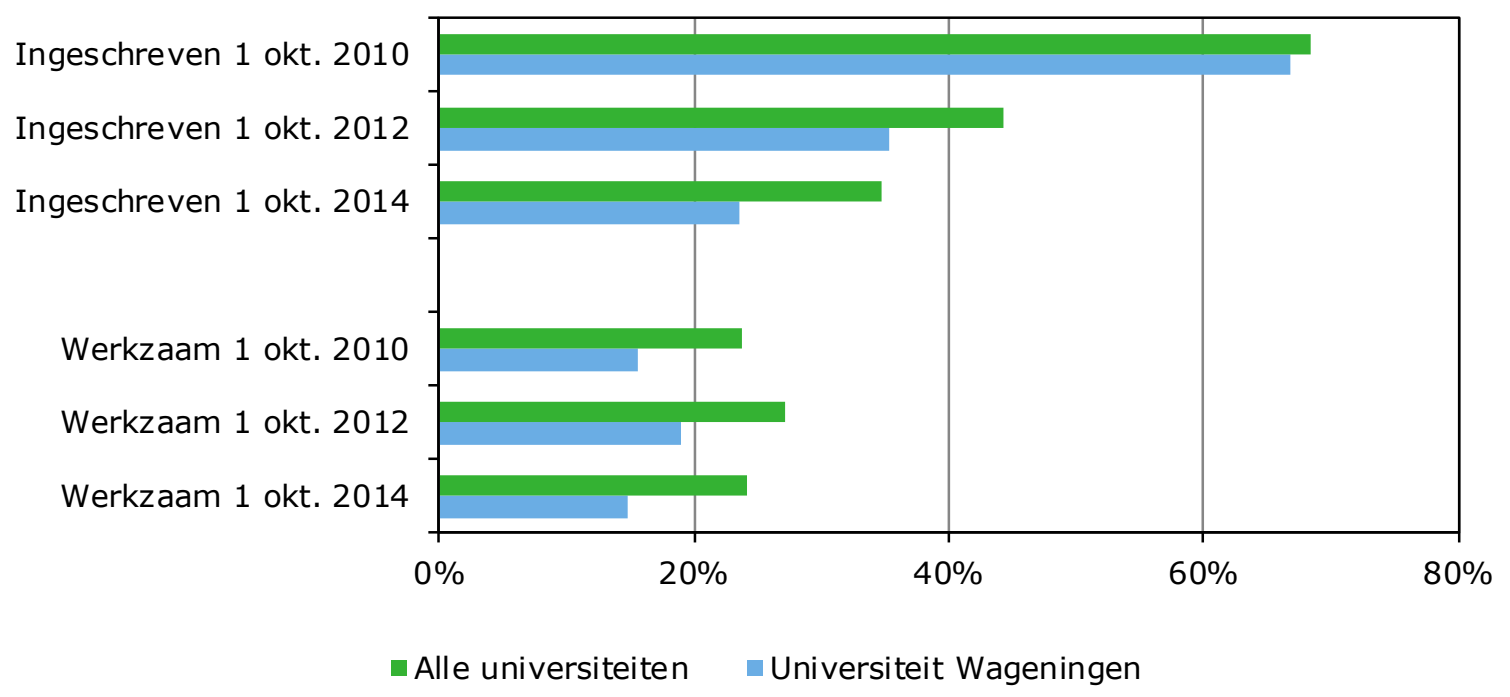

Figuur 5.18 Woon- en werkstatus van internationale wo-alumni vanuit afstudeerjaar 2009/2010. Voetnoot: het betreft hier percentages van het totaalaantal internationale alumni aan Nederlandse universiteiten die bij afstuderen een BRP-inschrijving hadden (afstudeerjaar 2009/2010).

Bron: $C B S$.

\subsubsection{Weinig bedrijfsoprichtingen door internationale wo-alumni}

Naast inschrijving en werkgelegenheid is ook onderzoek gedaan naar de mate van bedrijfsoprichting door internationale alumni van Nederlandse universiteiten. Voor heel Nederland geldt dat ruim $6 \%$ van de internationale (geregistreerde) studenten binnen zeven jaar na afstuderen in Nederland een bedrijf opricht. Dit percentage is in de loop van de tijd aardig stabiel. Voor Wageningse internationale alumni ligt dat percentage aanmerkelijk lager, deels dus doordat Wageningen relatief veel alumni heeft die Nederland snel weer verlaten. Over drie jaren gemeten, richt ruim $2 \%$ van de alumni binnen zeven jaar een bedrijf op in Nederland. 


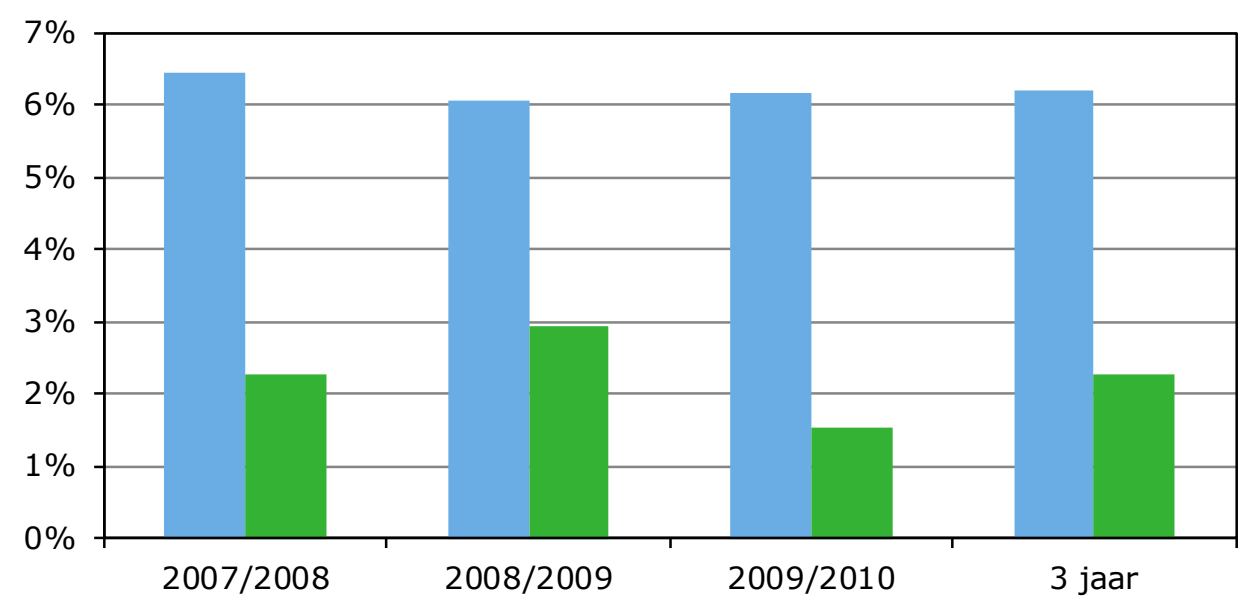

Alle universiteiten Universiteit Wageningen

Figuur 5.19 Het percentage bedrijfsoprichtingen door internationale wo-alumni. Het betreft hier percentages van het totaalaantal internationale alumni aan Nederlandse universiteiten die bij afstuderen een BRP-inschrijving hadden.

Bron: $C B S$.

In onderzoek van Nuffic (2018) is aangetoond dat de universiteit Wageningen na de Universiteit Maastricht en de Universiteit Twente het meeste gericht is op internationale studenten. In 2016 ging het om $24 \%$ internationale studenten. Dat is ruim minder dan Maastricht (58\%) en iets minder dan Twente (25\%).

Een groot verschil is dat Maastricht vooral veel Duitse studenten heeft en Wageningen vooral gericht is op landen van buiten de EU. Drie op de tien niet-EU-studenten is Chinees en twee op de tien Indonesisch. Chinezen in Nederland kiezen als studierichting na economie en techniek het meest voor landbouw en de natuurlijke omgeving. Chinese afgestudeerden zijn na vier jaar ongeveer even vaak ingeschreven als andere afgestudeerden van buiten de EU en zijn bovengemiddeld vaak werkzaam in Nederland, maar richten wel minder dan gemiddeld vaak bedrijven op in Nederland (CBS, 2018e).

Uit nieuw onderzoek (Laursen et al., 2018) is overigens gebleken dat pas aangeworven hoogopgeleide migranten een sterkere bijdrage leveren aan de innovatieve slagkracht van bedrijven dan hoogopgeleide Nederlanders. De innovatiebonus is sterker indien ze nog relatief kort in Nederland werken en ze afkomstig zijn uit landen die op cultureel vlak sterk verschillen van Nederland. Een belangrijke randvoorwaarde is dat bedrijven een zekere mate van ervaring hebben opgebouwd in het werken met migranten en de nodige ondersteuning geïmplementeerd hebben.

\subsection{De biologische Agro/Food-sector}

De biologische Agro/Food-sector in Nederland is beperkt van omvang, maar neemt nog steeds toe. De sector kent naast land- en tuinbouwbedrijven die voor de primaire biologische productie zorgen ook nog andere gecertificeerde biologische activiteiten in de Agro/Food-sector: verwerking, import van buiten de EU, export naar landen buiten de EU en overige activiteiten, zoals groothandel, detailhandel, handel binnen de EU, horeca, opslag, agrarische dienstverlening en dergelijke. Veel bedrijven die actief zijn binnen de biologische sector, zijn gecertificeerd voor meer dan één activiteit. In de bijlage is een definitie opgenomen van het begrip 'biologisch'. 


\subsubsection{Biologische landbouwproducenten}

Eind 2017 waren er in Nederland 1.696 biologisch gecertificeerde landbouwbedrijven voor biologische productie. Ten opzichte van 2016 is dat een toename van $9 \%$. Daarmee is $2,9 \%$ van de bedrijven uit de landbouwtelling biologisch. Het biologisch beteelde areaal omvat 3,2\% van de totale beteelde landen tuinbouwgrond. Nederland behoort daarmee binnen de EU tot de kleine landen. In het voedseleconomisch bericht wordt dit nader toegelicht: "Qua aandeel vormen Oostenrijk (22\%), Estland (19\%) en Zweden (18\%) de top drie binnen de EU. Dit is toe te schrijven aan een combinatie van overheidssubsidies die de biologische landbouw hebben gestimuleerd en aan een van oudsher al extensieve(re) bedrijfsvoering. In de ons omringende landen ligt het aandeel biologisch op circa $8 \%$ in Duitsland en Denemarken, en rond de 6\% in België en Frankrijk. Het Verenigd Koninkrijk en Luxemburg zitten met 3\% in de buurt van Nederland. In Italië vond in 2016 binnen de EU de sterkste groei in biologisch areaal plaats (+300.000 ha). Het aandeel biologisch areaal in Italië steeg tussen 2015 en 2016 met bijna 3\% naar 15\% (FiBL \& IFOAM, 2018)".

Naast primaire activiteiten heeft een deel van de biologische landbouwbedrijven nog andere biologisch gecertificeerde activiteiten. Dat gaat op voor $17 \%$ van de biologische boeren. Het grootste deel van die aanvullende activiteiten (65\%) bestaat uit verwerking van de biologische productie tot bijvoorbeeld kaas en boter.

\subsubsection{Verwerkende bedrijven}

Eind 2017 waren er 1.191 gecertificeerde biologische verwerkende bedrijven. Ook bij de verwerkers is een toename te zien, maar het aantal biologische verwerkers is in vergelijking met 2016 gestegen met $2 \%$. Dat is een duidelijk minder sterke toename dan in 2016 ten opzichte van 2015 . Toen steeg het aantal verwerkers met $15 \%$.

\subsubsection{Import/export}

Het aantal gecertificeerde importeurs en exporteurs is in de afgelopen jaren ook toegenomen. In 2017 waren er 87 gecertificeerde exporteurs, een stijging van $7 \%$ in vergelijking met 2016 . Het aantal importeurs is in diezelfde periode met $4 \%$ toegenomen tot een aantal van 507 . Het gaat hierbij om handel met landen buiten de Europese Unie. Voor handel in biologische producten binnen de EU is geen aparte certificering noodzakelijk.

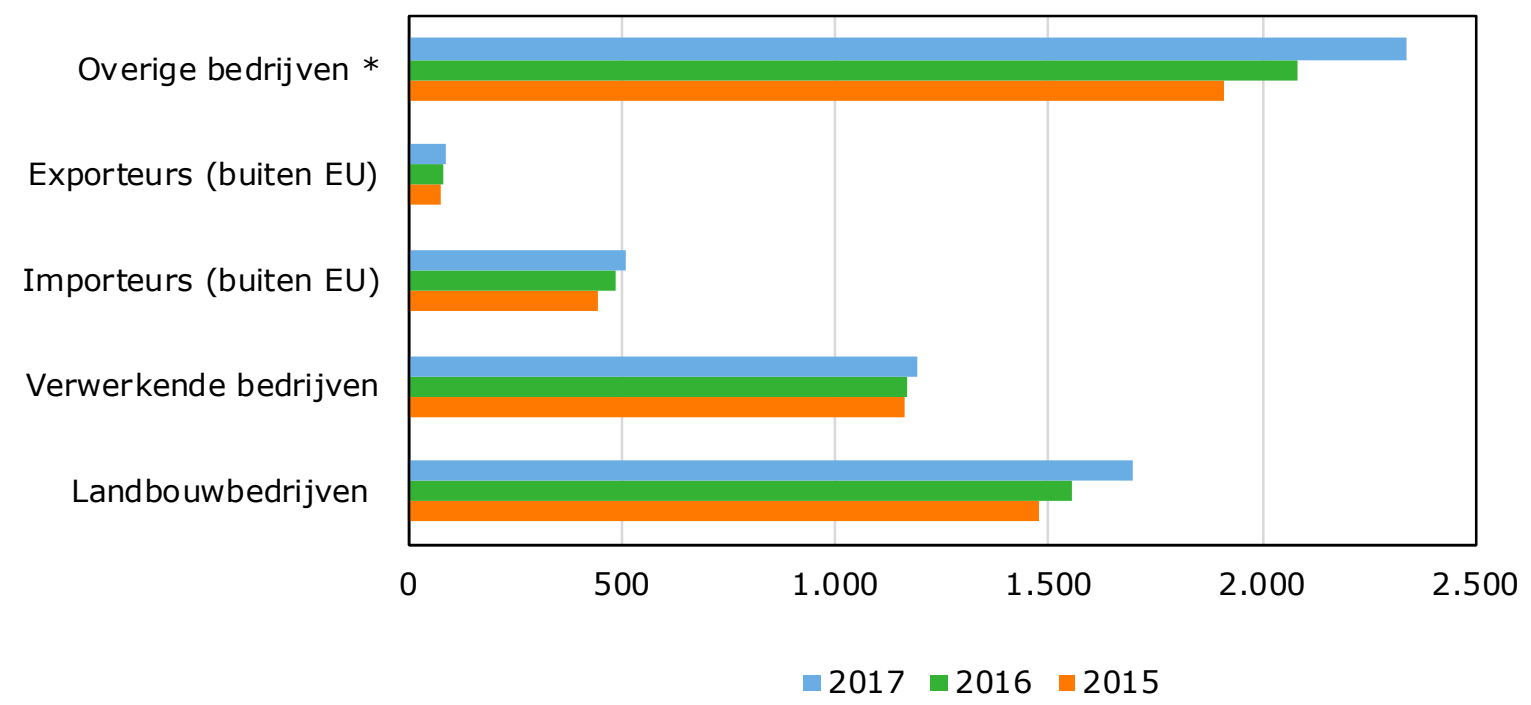

Figuur 5.20 Aantal gecertificeerde bedrijven per activiteit, 2015-2017.

Voetnoot: * groothandel, detailhandel, handel binnen EU, horeca, opslag, agrarische dienstverlening en dergelijke.

Bron: $C B S$. 


\subsection{Mate van gebruik duurzame agrogrondstoffen in Nederland wisselend}

Volgens de definitie in het Brundtland-rapport 'Our common future' (1987) wordt bij een duurzame ontwikkeling voorzien in de behoeften van de huidige generatie, zonder daarbij de behoeften van toekomstige generaties in gevaar te brengen. In het rapport wordt een verbinding gelegd tussen economische groei, milieuvraagstukken en armoede- en ontwikkelingsproblematiek. Het rapport stelt dat armoede een belemmering vormt voor duurzaam gebruik van de natuurlijke omgeving en dat integratie van natuurbehoud en economische ontwikkeling nodig is voor duurzame ontwikkeling.

Duurzaamheid is een breed begrip, dat ook steeds breder wordt gehanteerd. In Nederland hebben marktpartijen zich verbonden aan concrete mijlpalen op weg naar een toenemend gebruik van duurzaam geproduceerde agrogrondstoffen. Dit streven naar verduurzaming is vastgelegd in een aantal convenanten en initiatieven voor verschillende sectoren. De betrokken partijen monitoren de doelstellingen vaak zelf, waarbij het CBS op verzoek van het ministerie van LNV dit proces valideert. Dat wil zeggen dat het CBS de bij het monitoren gebruikte (statistische) methoden toetst. Als de marktpartijen de doelstellingen niet zelf monitoren, kan het CBS bepaalde indicatoren voor de monitoring berekenen. Dat laatste geldt bijvoorbeeld voor indicatoren voor de verduurzaming van kweekvis (2013-2015), voor cacao (2014-2016) en voor groenten en fruit uit ontwikkelingslanden (2014-2015).

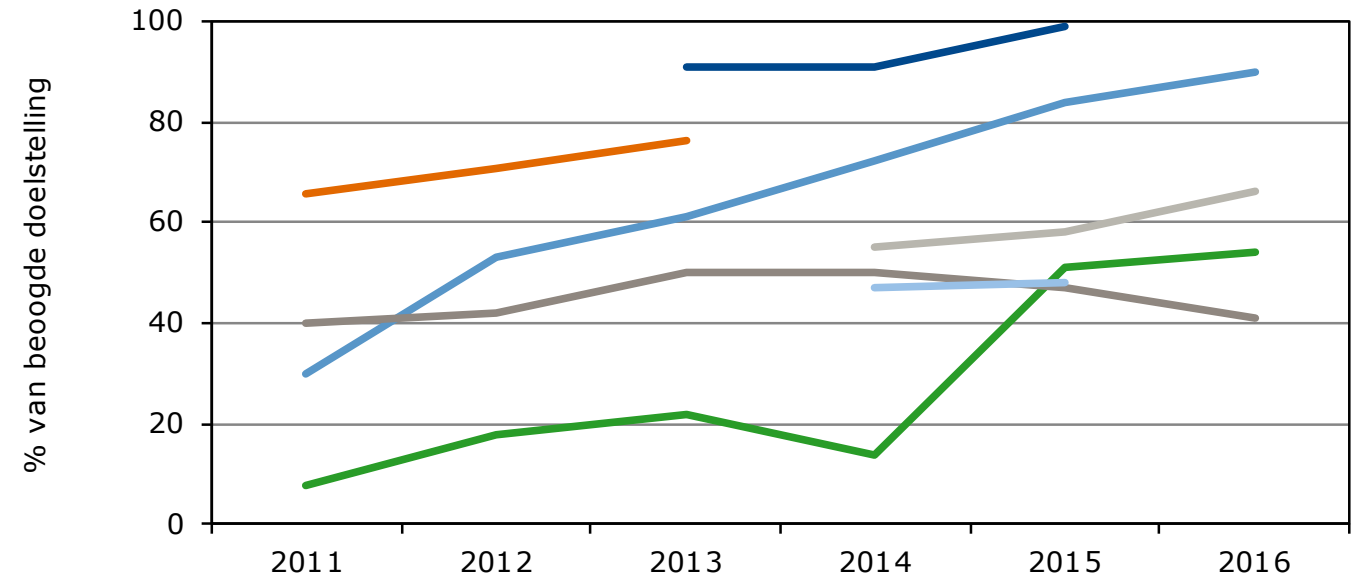

\footnotetext{
Palmolie (verbruik voedingsmiddelenindustrie) - Soja (verbruik diervoederindustrie)

Hout (beschikbaar gekomen op markt)

Koffie (gedronken of verkocht)

Pangasius (afzet in supermarkten)

Cacao (afzet in supermarkten)

Bananen (afzet in supermarkten)
}

Figuur 5.21 Verduurzaming van agrogrondstoffen in Nederland (\% van beoogde doelstelling). Bron: CBS, MVO, Probos, Nevedi, KNVKT.

Het CBS rapporteert de resultaten in de jaarlijkse Monitor Duurzame Agro-grondstoffen (CBS, 2016c en 2017d), waarbij de definitie van duurzaamheid wordt gehanteerd zoals die in de verschillende convenanten is vastgesteld. De meeste convenanten baseren zich daarbij op één of meer keurmerken om duurzaamheid te kunnen definiëren. De keurmerken hebben elk hun specifieke eisen wat betreft natuur, milieu, mens en werk. De convenanten richten zich meestal op een specifieke plaats in de keten (van productie tot consumptie). De gekozen indicatoren voor de verduurzaming van de agrogrondstoffen zullen daardoor niet zonder meer met elkaar te vergelijken zijn. 
De convenanten eindigen in verschillende jaren. Voor palmolie, soja, hout en koffie is het laatste jaar 2015 , voor kweekvis 2016, voor verse groente en fruit 2020 en voor cacao 2025 . De doelstelling is voor koffie $75 \%$ en voor de andere agrogrondstoffen $100 \%$ duurzaam. Het percentage neemt aanvankelijk toe, maar de uiteindelijke doelstelling blijkt niet voor alle agrogrondstoffen haalbaar. Een reden kan zijn dat bij de convenantpartijen andere duurzaamheidsaspecten, zoals de ecologische voetafdruk van de producten, ook een rol zijn gaan spelen. Verder blijkt een relatief geringe groei van de vraag naar duurzame producten in de afnemende landen een rem te zijn op de exportgroei van duurzame productie (CBS, 2016c en 2017f).

De doelstelling voor duurzame palmolie is niet gehaald, maar de betrokken partijen zijn na 2015 verder gegaan met de verduurzaming van de palmolieketen. De doelstelling werd hierbij aangescherpt en de monitoring van het verbruik van duurzame palmolie is op dezelfde voet voortgezet.

Door een beperkte marktvraag naar duurzame soja was de doelstelling voor 2015 niet haalbaar. De diervoederindustrie is vanaf 1 januari 2015 doorgegaan met een nieuwe doelstelling. In het nieuwe convenant hebben de leden van Nevedi met elkaar afgesproken om vanaf 1 januari 2015 alleen soja in te kopen die voldoet aan minimumduurzaamheidseisen (Nevedi, 2014).

Voor de productie van vlees en eieren voor de binnenlandse markt wordt alleen duurzame soja gebruikt. Bij de productie van vlees en eieren voor de buitenlandse markt wordt soja gebruikt die aan de gestelde minimumduurzaamheidseisen voldoet. De zuivelindustrie stelt als eis voor de productie van zuivel dat voor zowel voor de binnenlandse als de buitenlandse markt duurzame soja wordt gebruikt.

Over het gebruik van duurzaam geproduceerd hout is geen convenant afgesproken, maar wel was hout onderdeel van het Beleidsprogramma Biodiversiteit (2008-2011) en heeft het kabinet in 2008 tot doel gesteld dat in het jaar 2011 van al het hout dat op de Nederlandse markt komt minstens 50\% duurzaam moet zijn geproduceerd. In de Green Deal 'Bevorderen duurzaam bosbeheer' is een monitoring over 2013 en 2015 van het aandeel duurzaam hout op de Nederlandse markt opgenomen. Ook over 2017 zal het marktaandeel aantoonbaar duurzaam geproduceerd hout en papier op de Nederlandse markt worden gemonitord. 


\section{$6 \quad$ Handel en circulariteit: consequenties van kringlooplandbouw voor handel}

\subsection{Inleiding}

De Nederlands landbouw- en voedingsmiddelensector is sterk internationaal georiënteerd. Veel grondstoffen worden geïmporteerd en een belangrijk deel van de productie wordt in de vorm van halffabricaten en eindproducten geëxporteerd. Bij de grondstofimporten gaat het voor een deel om gewassen die niet op Nederlandse bodem kunnen worden geproduceerd - denk aan cacao, koffie en tropisch groente en fruit. Daarnaast vormt, naast de invoer van granen, de invoer van met name eiwitrijke veevoeders een belangrijk onderdeel van agrarische importen. Zo maken de open grenzen ${ }^{9}$ het mogelijk dat de Nederlandse veehouderij veel groter is dan deze op basis van eigen geproduceerd veevoer zou kunnen zijn en dat de sector in 2018 ter waarde van 16,6 miljard euro exporteert (tabel 2.2 en 2.3 in dit rapport). Hierdoor is ook het aandeel van de veehouderij in de uitstoot van broeikasgassen en ammoniak groter dan zonder de invoer van veevoer het geval zou zijn geweest. De huidige omvang van de veestapel leidt lokaal tot een mineralenoverschot (van fosfaat en stikstof) in bodem en water en veroorzaakt geur- en fijnstofhinder. Dit heeft negatieve gevolgen voor de bodem-, water- en luchtkwaliteit in Nederland.

Door 'kringlooplandbouw' te stimuleren, wil het ministerie van LNV bereiken dat de sector minder broeikasgassen uitstoot, dat de bodemkwaliteit verbetert en dat eindige grondstoffen (zoals fosfor) in de sector efficiënter worden gebruikt. Nog niet duidelijk is hoe zo'n kringlooplandbouw eruit zal/moet zien. Een aanknopingspunt zou gevonden kunnen worden in de Uitvoeringsagenda Duurzame Veehouderij (UDV), opgesteld in 2009 als convenant tussen bedrijfsleven, maatschappelijke organisaties en het ministerie van LNV. Een van de speerpunten van deze Uitvoeringsagenda is het vóór 2023 sluiten van de voer-mestkringloop (zie www. uitvoeringsagendaduurzameveehouderij. nl). Hiervoor heeft men drie denkrichtingen opgesteld: een sluiting van de kringloop op mondiale schaal, op Europese schaal en op nationale schaal ${ }^{10}$. In dit hoofdstuk worden de gevolgen geschetst van deze denkrichtingen voor de Nederlandse import- en exportstromen, naast de ecologische effecten die verwacht mogen worden. Ook wordt ingegaan op de vraag welke instrumenten kunnen worden ingezet om de gewenste schaal van de kringloop te bereiken. In deze beknopte bijdrage worden de eerste-orde effecten beschreven en wordt geen rekening gehouden met gevolgen van veranderende beschikbaarheid van en kosten voor voer en mest, waardoor allerlei substitutie- en/of gedragsveranderingen de uiteindelijke effecten van de scenario's zullen beïnvloeden.

\subsection{Mondiaal transport}

In dit scenario sluit Nederland de voer-mestkringloop door mineralen (uit bewerkte mest) terug te transporteren naar de landen waar de voederproductie plaatsvindt. In dit scenario wordt uitgegaan van een technische oplossing van het mineralenoverschot, door fosfor terug te winnen en mest zodanig te bewerken dat het op mondiale schaal kan worden getransporteerd.

\subsubsection{Economie: weinig gevolgen}

Het gevolg is dat de omvang van de Nederlandse veestapel onveranderd kan blijven en in ieder geval niet krimpt, doordat met mestexport de mineralenbalans binnen de (verlies)normen zal kunnen blijven. De verwachting is dan dat bij dit scenario de sector de huidige prestaties op het gebied van productie, toegevoegde waarde en export kan blijven realiseren. Ook bestaande invoerstromen van veevoercomponenten blijven in dit scenario onveranderd.

9 In internationale afspraken in GATT- en WTO-verband is vastgelegd dat de invoer van eiwitrijke gewassen (onder andere soja en maisglutenvoermeel) niet belast wordt met importheffingen.

${ }^{10}$ Zie de Argumentenkaart van de Argumentenfabriek die in dit kader is opgesteld. 
De cruciale vraag is of mestverwerking en -transport naar de herkomstlanden van het geïmporteerde voer economisch rendabel is. Er zijn de afgelopen jaren flinke stappen gezet op het gebied van be/verwerking van pluimveemest (zie onder andere Luesink et al., 2016). Zo wordt rond een derde van het mestvolume verbrand (voor energieopwekking) en wordt momenteel al een aanzienlijk deel van de pluimveemest in droge vorm en/of korrelvorm geëxporteerd, bijvoorbeeld naar buurlanden Duitsland en Frankrijk, en ook naar Latijns-Amerika en Azië (in zeecontainers, als retourvracht). De verwerking van varkensmest komt nog wat traag op gang, maar zou bij de huidige mestprijzen (wat boeren bereid zijn om te betalen voor hun mestafzet) wel rendabel te maken zijn: varkensmestprijzen (per kuub) liggen momenteel zo'n 10-30\% hoger dan de break-even prijzen voor rendabele mestverwerking (mondelinge informatie Harry Luesink). Voorts is er in potentie meer dan genoeg afzetruimte in Europa voor gedroogde Nederlandse mest en mestkorrels (zie bijvoorbeeld Ros et al., 2014).

\subsubsection{Ecologie: mineralenbalans in evenwicht, maar geen reductie van broeikasgasemissies}

Met de uitvoer van mest naar mesttekortgebieden zal de mineralenbalans beter in evenwicht komen en zullen de verliezen veel geringer zijn. De uitstoot van broeikasgassen $\left(\mathrm{CO}_{2}\right.$, methaan en lachgas) en ammoniak zal bij een onveranderde omvang van de veestapel echter niet verminderen. Daar komt bij dat als de concentratie van dieren gelijk blijft, ook de geur- en fijnstofhinder, en de gezondheidsrisico's in verband met zoönoses, niet veranderen (De Wolf et al., 2018).

\subsubsection{Governance: regelgeving op gebied van ruimtelijke ordening en kwaliteit mestproducten}

Om goede technieken voor mestverwerking rendabel te exploiteren, zijn grote hoeveelheden mest nodig. De voer-mestkringloop sluiten via mondiaal mesttransport vergt dan ook mestverwerking op grote schaal. De huidige hoogte van de afzetkosten voor varkensmest zou ook investeringen in grootschalige mestverwerking mogelijk maken. Er zijn diverse particuliere investeringsinitiatieven waarbij varkenshouders ook financieel deelnemen; zo'n vorm van participatie kan behulpzaam zijn om de op te zetten verwerkingscapaciteit en aanvoer op elkaar af te stemmen. De rol van de overheid is dan vooral gelegen op het vlak van regelgeving. Voor het plaatsen van mestverwerkingsinstallaties is veelal een bestemmingsplanwijziging nodig; dit kan een tijdrovende procedure zijn. Daarnaast is ook regelgeving in het ontvangende land van belang: om toegelaten te worden, dient te worden voldaan aan de kwaliteitseisen van het bemestingsproduct die het importerende land eraan stelt. Overigens wordt op EU-niveau gewerkt aan uniforme regelgeving op dit terrein ${ }^{11}$.

\subsection{Europees evenwicht}

Het uitgangspunt van dit scenario is het verminderen van de invoer van veevoergrondstoffen door de kringloop te sluiten op Europese schaal (gedefinieerd in het UDV-scenario als EU en Oekraïne). De veehouderij in Nederland zal meer gebruik maken van in Europa geteelde eiwithoudende gewassen als vervanging van eiwitrijke veevoercomponenten die afkomstig zijn uit andere continenten. De vraag is wat dit betekent voor de Nederlandse import van veevoer, de productie en toegevoegde waarde in de veehouderijsector, en de uitvoer van vlees en zuivel (en ook van veevoeders), en welke ecologische winst (reductie van emissies, terugdringen van mineralenoverschot, bodem en waterkwaliteit) dit scenario kan opleveren.

\subsubsection{Economie: kwart minder export}

Een eerste vraag is hoe groot de invoer van veevoeders uit niet-Europese landen is, die dus in dit scenario zal weg vallen en - voor zover mogelijk - dient te worden vervangen door Europese

\footnotetext{
${ }^{11}$ Zie http://www.europarl.europa.eu/news/nl/press-room/20181119IPR19407/fertilisers-cadmium-parliament-and-councilnegotiators-reach-provisional-deal.
} 
substituten. In 2016/2017 was de vraag van de Europese veevoerindustrie naar eiwitrijke gewassen (veelal in de vorm van zogenaamde 'co-products', eiwitrijk voer in de vorm van schroot of meel dat resulteert uit crushing of verwerking van gewassen) zo'n 25 miljoen ton eiwithoudende gewassen (in de vorm van schroot, zaden of bonen) (EC, 2018). Hiervan werd 17 miljoen ton geïmporteerd van buiten de EU (zie ook Protein Balance Sheet van de EU) ${ }^{12}$. Bij een verondersteld (gemiddeld) eiwitgehalte van 35\% geeft dat een volume van 5,95 miljoen ton 'eiwitequivalenten' die van buiten de EU worden ingevoerd.

Er zijn twee alternatieven voor de van buiten de EU ingevoerde eiwitrijke gewassen om te voorzien in de eiwitbehoefte van de huidige veestapel in de EU: meer productie van deze gewassen in de EU en/of meer invoer vanuit Oekraïne. Oekraïne is een belangrijke producent en exporteur van granen (tarwe, mais, en gerst) en van diverse oliehoudende gewassen (koolzaad, zonnebloemzaad en sojabonen). Servië, ook een producent en exporteur van sojabonen en zonnebloemzaad buiten de EU, kan deze producten leveren, maar het aanbod is relatief gering, waardoor deze optie buiten beschouwing wordt gelaten.

Gewassen in de EU die als vervanging kunnen dienen voor geïmporteerde soja, palmolieproducten en andere eiwithoudende veevoeringrediënten, zijn eiwithoudende gewassen met meer dan $15 \%$ eiwit. Dit zijn: oliezaden (koolzaad, zonnebloemzaad, sojabonen) en peulvruchten (erwten, veldbonen, linzen, lupine $)^{13}$. Daarnaast is ruwvoer, zoals grasklaver en alfalfa, ook een belangrijke eiwitbron. In de EU vindt sojaproductie met name plaats in Italië, Frankrijk en Roemenië en peulvruchten worden vooral geproduceerd in Frankrijk, Spanje en Litouwen (erwten) (zie EC, 2018). Het areaal en daarmee ook de productie van deze gewassen groeit in diverse lidstaten, onder meer dankzij vergroeningsmaatregelen die deel uitmaken van het GLB (sinds 2014).

Eiwithoudende gewassen in de EU kunnen moeilijk concurreren met aanbod van buiten de EU: de opbrengsten per hectare zijn relatief laag en door het ontbreken van Europese importbescherming volgen de prijzen die van de internationale markten, waardoor (hectare)saldo's lager uitkomen dan die voor alternatieve gewassen. Met het verbeteren van teeltkennis en variëteiten, al dan niet in combinatie met prijssteun of andere vormen van beleidsondersteuning (bijvoorbeeld directe inkomenstoeslagen die zijn gekoppeld aan bredere gewasrotaties in de akkerbouw met het oog op bodemvruchtbaarheid) kan de teelt op termijn economisch aantrekkelijker worden in de EU, maar dat zal wel enige tijd nodig hebben (zie ook Fefac, 2018; EC, 2018). Uitbreiding van de eigen Europese productie van eiwithoudende gewassen zal daarom de eerstkomende jaren weinig soelaas bieden als veevoerimporten uit andere continenten worden beëindigd.

De tekorten aan eiwithoudende gewassen in de EU - ter vervanging van geïmporteerde eiwithoudende gewassen uit andere continenten in dit scenario - zullen dan in eerste instantie (nog) meer uit Oekraïne moeten worden aangevuld. De EU voert al aanzienlijke volumes voergranen (vooral mais) en eiwithoudende gewassen in uit Oekraïne (tabel 6.1). Als de EU-afzetmarkt (via hogere prijzen die een gevolg zijn van het tekort in de EU) aantrekkelijker wordt voor Oekraïense exporteurs, kan een groter deel van de Oekraïense productie en export naar de EU komen. Andere belangrijke afnemers van Oekraïne van deze gewassen, zoals Wit-Rusland, Afrika en het Midden-Oosten, zullen dan hun aanvoer van elders moeten halen. Stel dat Oekraïne al zijn export van voergranen en eiwithoudende gewassen naar de EU zou exporteren, dan betekent dat voor de EU een extra invoer van 15 miljoen ton voergraan en 4,7 miljoen ton eiwithoudende gewassen. Omgerekend naar eiwitequivalenten betekent dat een invoer van 2,7 miljoen ton (optelsom van de volumes in de laatste kolom in tabel 6.1) ${ }^{14}$. Hiermee wordt het tekort van 5,95 miljoen eiwit voor minder dan de helft gedekt, en is 3,25 miljoen

\footnotetext{
12 In volume gaat het vooral om sojabonen en sojaschroot, zonnebloemzaad en raapzaad.

13 De verwerking van eiwithoudende gewassen in veevoer is gebaseerd op een combinatie van economische (dat wil zeggen de prijs) en technische parameters, waarbij de laatste verwijzen naar specifieke voedingsvoorwaarden om de dieren gezond en efficiënt te laten groeien en/of te produceren. Veevoeders zijn complexe samengestelde producten: fabrikanten maken gebruik van (economische en technische) optimalisatiemodellen om te bepalen welke grondstoffen zij gebruiken. In onze analyse is tamelijk grof te werk gegaan, door te veronderstellen dat het ene eiwithoudende gewas (soja) kan worden vervangen door het andere eiwitrijke (erwten/bonen/lupine enzovoort).

${ }^{14}$ De aanname in dit voorbeeld is dat productie in en exportsurplus van Oekraïne van deze gewassen constant blijven, en dus niet reageren op toename van de vraag naar deze gewassen in Europa.
} 
ton, oftewel (afgerond) 37\% (van 8,75 miljoen eiwit ${ }^{15}$ ), aan eiwit minder beschikbaar voor de Europese veevoerindustrie dan nu het geval is.

Tabel 6.1 Oekraïne's export van voedergraan en eiwithoudende gewassen: totale export en export naar de EU (in tonnen, gemiddelden van 2015-2017).

\begin{tabular}{|c|c|c|c|c|}
\hline & $\begin{array}{l}\text { Totaal export } \\
\text { volume }\end{array}$ & $\begin{array}{l}\text { Waarvan naar } \\
\text { EU-28 }\end{array}$ & \multicolumn{2}{|c|}{$\begin{array}{l}\text { Maximaal extra invoer van EU uit Oekraïne van } \\
\text { eiwithoudende gewassen (in tonnen product) }\end{array}$} \\
\hline & Oekraïne & & In tonnen product & In tonnen eiwit \\
\hline Sojabonen & 2,6 miljoen & 500.000 & 2,1 miljoen & 735.000 \\
\hline Raap-/koolzaad & 1,5 miljoen & 1,2 miljoen & 0,3 miljoen & 105.000 \\
\hline Sojaschroot & 300.000 & 50.000 & 250.000 & 112.500 \\
\hline $\begin{array}{l}\text { Ander schroot dan van } \\
\text { sojabonen }\end{array}$ & 4,3 miljoen & 2,3 miljoen & 2 miljoen & 500.000 \\
\hline
\end{tabular}

Bron: COMTRADE. Omrekeningsfactor bij voergranen is 0,085 ; bij eiwithouden gewassen is dit 0,35 voor sojabonen en voor raapzaad, 0,25 voor zonnebloemzaad, 0,45 voor sojaschroot en 0,25 voor ander schroot dan van sojabonen.

Bovenstaande is een (zeer) optimistische inschatting van de hoeveelheid eiwit die uit Oekraïne kan worden geïmporteerd; een import die wellicht alleen tot stand zal komen als, vanwege de vraagtoename in de EU die het gevolg is van een oplopend tekort aan plantaardig eiwit, de prijzen voor deze gewassen fors toenemen. In 'een dergelijke marktsituatie mag ook worden verwacht dat de samenstelling van het veevoer in de EU verandert, althans bij een deel van de veestapel. Zo zou een deel van de rundveestapel meer ruwvoer kunnen gaan gebruiken (bijvoorbeeld een combinatie van gras en snijmais). In een diepgaandere vervolganalyse van de dynamiek van de veevoermarkt dient aandacht te zijn voor dergelijke (technische en economische) substitutiemogelijkheden in het veevoer voor de diverse diersoorten in de EU, met daarbij ook de reacties in het teeltplan in de EU-lidstaten (verschuivingen in teelten en veranderend aanbod). Een dergelijke analyse valt buiten de reikwijdte van deze analyse.

Rekening houdend met de grove aannames zoals hierboven verwoord, is de inschatting van dit scenario dat bij een maximaal gebruik van de beschikbare veevoergrondstoffen (granen en eiwithoudende gewassen) uit Oekraïne de Europese veevoerindustrie te maken krijgt met $37 \%$ minder eiwitrijke veevoeringrediënten. Dit leidt tot een veestapelreductie, die waarschijnlijk niet in dezelfde orde van grootte ligt, maar wel fors zal zijn. De afname van het aantal dieren hangt af van veranderingen in de voersamenstelling (waarbij bijvoorbeeld ook gedacht kan worden aan meer gebruik van synthetische aminozuren) en van het feit of men (een beperkte mate van) minder technische resultaten (bijvoorbeeld in de vorm van een lager eiwitgehalte in melk) zal accepteren. Een veestapelreductie van zo'n $25 \%$ zou dan een voorstelbare uitkomst kunnen zijn.

Mogelijk kan dit percentage in Nederland wat lager uitvallen vanwege de relatieve sterkte van de sector, die is gebaseerd op een hoog kennisniveau en efficiënte productieprocessen en logistieke processen ${ }^{16}$, maar vooralsnog is er uitgegaan van een evenredige afname van de veestapel in Nederland. Een daling van de veestapel van $25 \%$ in Nederland leidt tot afname van de productie- en exportwaarde van de vlees- en zuivelsectoren in dezelfde orde van grootte. In de situatie met een tekort aan plantaardig eiwit op de Europese markt, zal ook de Nederlandse export van veevoer fors lager zijn dan de huidige 4,5 miljard euro.

\footnotetext{
${ }^{15} 8,75$ miljoen ton eiwitequivalent $=0,35 \times 25$ miljoen ton eiwithoudende gewassen.

${ }^{16}$ Hierdoor zal het nadeel (ten opzichte van bijvoorbeeld Frankrijk of enkele Midden-Europese landen) dat in Nederland de teelt van graangewassen en/of eiwithoudende gewassen wordt beperkt en dat deze voerproducten deels zullen moeten worden geïmporteerd uit andere EU-lidstaten, gering zijn.
} 


\subsubsection{Ecologie: minder mest, stikstofverliezen en broeikasemissies}

De ecologische gevolgen in Nederland van een kleinere veestapel zijn een lagere mestproductie, minder gebruik van fosfaat en andere mineralen vanwege minder (kracht)voergebruik, en een daling van de uitstoot van broeikasgassen en ammoniak. Een 25\% kleinere veestapel leidt tot minder stikstofverliezen vanwege een afname van de stalemissies doordat er minder dieren zijn, maar de aanwending van stikstof en fosfaat op de bedrijven zal hetzelfde blijven omdat (in dit scenario) de gebruiksnormen niet veranderen. De productie van mest en het fosfaatoverschot dalen wel en dat vertaalt zich in minder export van mest en fosfaat naar het buitenland.

\subsubsection{Governance: teeltstimulering wel, grensbescherming geen optie}

Een scenario als dit wordt werkelijkheid onder de veronderstelling dat in Europa (EU en Oekraïne) (veel) meer eiwithoudende gewassen worden geteeld dan op dit moment het geval is. Een actief steunbeleid om productie en productiviteit te verhogen is dan nodig. Met het EU-beleid wordt ingezet in op een groei van de opbrengsten per hectare via kennis en innovatiebeleid (EC, 2018), en krijgen lidstaten de mogelijkheid om door directe toeslagen de teelt te stimuleren. Zoals reeds gesteld, zal dergelijk beleid pas na enige tijd effect hebben op het aanbod. De concurrentiepositie van de teelt verbeteren door grensbescherming (tarieven of eventueel zelfs een verbod op importen), is onhaalbaar in verband met de Wereldhandelsorganisatie.

\subsection{Nationaal evenwicht}

In dit scenario is het uitgangspunt dat Nederland de voer-mestkringloop op eigen grond sluit, door de omvang van de veehouderij te reduceren tot deze in balans is met de feitelijke omvang van de voederproductie. Volgens de Argumentenkaart ${ }^{17}$ blijft Nederland ook dan vlees- en zuivelproducten exporteren.

\subsubsection{Economie: forse terugloop aantal dieren en daling export}

Er zijn verschillende studies die een beeld geven van de situatie waarin geen veevoer meer wordt ingevoerd. In de studie van Terluin et al. (2013) is berekend of Nederland op dit gebied zelfvoorzienend kan zijn in een situatie zonder in- en uitvoer. Volgens de studie zal in de situatie dat Nederland geen voer van buiten de grenzen importeert, de varkenssector in zijn geheel verdwijnen. Voor varkens is (geïmporteerde) soja een belangrijke bron van hoogwaardig eiwit in veevoer, dat daarnaast voornamelijk bestaat uit producten van Nederlandse en Europese herkomst en waardevolle reststromen uit de levensmiddelenindustrie. Restproducten uit de industrie (zoals bierbostel) gaan dan naar de rundveehouderij. De pluim- en rundveesector blijven wel bestaan, maar het aantal dieren zal in beide sectoren ongeveer halveren.

In deze 'autarkiestudie' wordt rekening gehouden met drie verschillende diëten (minimum, gezond, huidig) en twee productieniveaus (hoog en laag) per hectare en dier, waardoor ook de omvang van de veestapel varieert. In geen van de scenario's is sprake van export. Dit is vanwege het autarkieuitgangspunt, niet omdat het niet meer zou kunnen. In alle scenariovarianten is namelijk volgens de berekeningen nog landbouwgrond over, die kan worden ingezet ten behoeve van veevoerproductie. In het scenario met een dieet dat het meest overeenkomt met het huidige in Nederland en met productieniveaus per hectare en dier die overeenkomen met de huidige, zou 966 duizend hectare landbouwgrond over zijn (zie tabel 3.5, p. 58, Terluin et al. 2013).

Als op de in de vorige alinea genoemde arealen voedergewassen worden geproduceerd, kan de veestapel uitbreiden en produceren voor de export. Ook reststromen uit de voedings- en genotmiddelenindustrie ( $v \mathrm{mi}$ ) zullen meer voorhanden zijn dan in de studie van Terluin et al. is verondersteld, doordat de invoer van de vmi niet wordt beperkt. Bij nationale voorziening in veevoer zal de veestapel daardoor (veel) minder teruglopen dan in de autarkiestudie is berekend. Aanvullende

\footnotetext{
${ }^{17}$ Zie www.uitvoeringsagendaduurzameveehouderij.nl
} 
berekeningen en veronderstellingen - bijvoorbeeld over wat er gebeurt met de 966 duizend hectare zijn vereist om daar preciezere cijfers over te kunnen geven. Dat geldt ook voor het feit dat akkerbouwproducten ingevoerd kunnen blijven worden (wat in de autarkiesituatie niet kan), wat nog meer ruimte voor veevoerproductie oplevert.

Voor de effecten van dit scenario kan ook gebruik worden gemaakt van de uitkomsten van De Wolf et al., (2018, inclusief de daar gebruikte referenties). In deze studie wordt geconcludeerd dat een scenario met nationale voorziening in veevoer grote economische gevolgen heeft voor de Nederlandse veehouderij en de daarmee verbonden schakels in de keten, niet alleen doordat de export (vrijwel) verdwijnt, maar ook door forse inkrimping en verlies van schaalvoordelen.

In een wat oudere studie is gekeken naar de gevolgen van het bereiken van een evenwicht op de Nederlandse mestmarkt door inkrimping van de veestapel (Vrolijk et al., 2010). Evenwicht is dan de situatie waarbij de productie aan mineralen gelijk is aan de landbouwkundige aanwending van mineralen. De veestapel moet met maximaal 19,5\% verminderen bij een proportionele krimp van de veestapel. In het scenario waarbij verschuivingen tussen sectoren mogelijk zijn, is het aantal melk- en kalfkoeien $12 \%$ lager dan in de uitgangssituatie, het aantal fokvarkens $30 \%$ lager en het aantal vleesvarkens zelfs 35\%. De bijdrage aan de economie, in termen van toegevoegde waarde (TW) en werkgelegenheid, is een daling van maximaal 2,3 miljard euro en een afname van het aantal arbeidsplaatsen met 39.000. De effecten voor de overige schakels van het agrocomplex zijn daarin meegenomen. Dit zijn geen geringe bedragen, maar afgezet tegen de totale Nederlandse economie gaat het om maximaal een half procent van de TW en de werkgelegenheid.

\subsubsection{Ecologie: milieuproblemen opgelost}

Wat betreft mest en mineralenconcentraties zijn er bij een afname van de veestapel minder tot mogelijk geen problemen meer (en dus ook geen kosten voor de sector). Ook de geur- en fijnstofhinder en gezondheidsrisico's zijn veel minder, alhoewel het sluiten van een nationale voermest kringloop niet per definitie een geconcentreerde veehouderij zal kunnen uitsluiten met lokale piekbelastingen.

\subsubsection{Governance: alleen aanwendingsnormen en/of dierrechten effectief instrument}

Voor het realiseren van voorziening van de veehouderij met alleen nationaal geteelde veevoergrondstoffen, inclusief reststromen uit de vmi, zijn niet direct instrumenten voorhanden waarmee kan worden gestuurd op de invoer. Heffingen/belastingen op import zijn binnen de EU en internationaal niet toegestaan. Binnen de keten zouden wel afspraken kunnen worden gemaakt om alleen nationaal geproduceerd veevoer te gebruiken. Ook kan er wel worden gestuurd op de mest- en mineralenproductie, via bijvoorbeeld gebruiksnormen of dierrechten.

\subsection{Slotbeschouwingen}

Bovenstaande denkrichtingen over het sluiten van de voer-mestkringloop zijn als uitgangspunt gebruikt voor een eerste invulling van wat kringlooplandbouw zou kunnen zijn. De analyses hebben een globaal karakter, waarbij de aandacht uitgaat naar eerste-orde effecten: om de dynamiek in kaart te brengen die ontstaat na beperkingen op de invoer van veevoedergrondstoffen in Nederland (op markten van veevoergewassen, vlees en zuivel), zullen aanvullende aannames en (waarschijnlijk ook model)simulaties moeten worden gedaan.

Bij analyses over het sluiten van de voer-mestkringloop gaat de aandacht vaak uit naar fosfor (of fosfaat), een eindige grondstof die door minder aanwending in de landbouw en via herwinning uit mest beter benut dient te worden. Momenteel vindt in Nederland (vrijwel) evenwichtsbemesting plaats, dat wil zeggen dat er evenveel fosfaat wordt onttrokken als aangevuld. Het grootste verlies van fosfor uit de kringloop treedt op via menselijke excretie die in het riool verdwijnt. Terugwinning van fosfor uit rioolslib zou een belangrijke bijdrage leveren aan een efficiënter gebruik van fosfor. 
Een nuancering past ook bij de gedachte dat minder import van soja, palmproducten en andere veevoercomponenten uit andere continenten zal leiden tot minder uitstoot van broeikasgassen (en minder ontbossing en biodiversiteitsverlies) in de gebieden waar veevoer vandaan komt. Dit mag zo zijn door de inkrimping van de veestapel die in Nederland (of Europa) plaatsvindt, maar de uiteindelijke gevolgen van 'een dergelijke ontwikkeling in Nederland/Europa hangen af van de vraag hoe de veehouderijsector in andere landen hierop reageert. Als andere landen in het gat springen dat $\mathrm{NL} / \mathrm{EU}$ op de afzetmarkten voor zuivel en vlees laat vallen, is het effect waarschijnlijk nihil.

Afname van of zelfs een verbod op de invoer van veevoer uit andere streken kan wel belangrijke lokale milieueffecten hebben, als lokale mineralenoverschotten ermee worden verminderd. Invoerbeperkingen laten zich echter lastig afdwingen; deelname aan de Wereldhandelsorganisatie verhindert nu eenmaal 'een dergelijke overheidsmaatregel. Aanwendingsnormen op het gebied van mest en dierrechten zijn dan effectiever om het milieu te ontzien. Op dat terrein liggen meer mogelijkheden voor nationaal beleid. 


\section{Literatuur en websites}

CBS (2015), Export babymelkpoeder naar China 50 keer hoger, 2 oktober 2015. Centraal Bureau voor de Statistiek: Heerlen/Den Haag. https://www.cbs.nl/nl-nl/nieuws/2015/40/export-

babymelkpoeder-naar-china-50-keer-hoger

CBS (2016a), Export van diensten goed voor 10 procent bbp, 13 oktober 2016. Centraal Bureau voor de Statistiek: Heerlen/Den Haag. https://www.cbs.nl/nl-nl/nieuws/2016/41/export-van-dienstengoed-voor-10-procent-bbp

CBS (2016b), Internationaliseringsmonitor 2016-II Agribusiness, 6 juni 2016. Centraal Bureau voor de Statistiek: Heerlen/Den Haag. https://www.cbs. nl/nl-

nl/publicatie/2016/23/internationaliseringsmonitor-2016-tweede-kwartaal

CBS (2016c), Monitor duurzame agrogrondstoffen 2016. Centraal Bureau voor de Statistiek: Heerlen/Den Haag. https://www.cbs.nl/nl-nl/economie/landbouw/monitor-duurzame-agrogrondstoffen-2016

CBS (2016d), Bijdrage wederuitvoer aan bbp in twintig jaar verdubbeld, 13 oktober 2016. Centraal Bureau voor de Statistiek: Heerlen/Den Haag. https://www.cbs.nl/nl-nl/nieuws/2016/41/bijdragewederuitvoer-aan-bbp-in-20-jaar-verdubbeld

CBS (2017a), Nederland tweede avocado-importeur ter wereld, 8 mei 2017. Centraal Bureau voor de Statistiek: Heerlen/Den Haag. https://www.cbs.nl/nl-nl/nieuws/2017/19/nederland-tweedeavocado-importeur-ter-wereld

CBS (2017b), Internationaliseringsmonitor editie Innovatie (2017-III), 26 september 2017. Centraal Bureau voor de Statistiek: Heerlen/Den Haag. https://www.cbs.nl/nl-

nl/publicatie/2017/39/internationaliseringsmonitor-2017-derde-kwartaal

CBS (2017c), Richting een toekomstbestendige agribusiness, 20 januari 2017. Centraal Bureau voor de Statistiek: Heerlen/Den Haag. https://www.cbs.nl/nl-nl/achtergrond/2017/03/richting-eentoekomstbestendige-agribusiness

CBS (2017d), Monitor duurzame agrogrondstoffen 2017. Centraal Bureau voor de Statistiek: Heerlen/Den Haag. https://www.cbs.nl/nl-nl/economie/landbouw/monitor-duurzame-agrogrondstoffen-2017

CBS (2018a), Energieverbruik verandert nauwelijks in 2017, 19 april 2018. Centraal Bureau voor de Statistiek: Heerlen/Den Haag. https://www.cbs.nl/nl-nl/nieuws/2018/16/energieverbruikverandert-nauwelijks-in-2017

CBS (2018b), Belang van Verenigd Koninkrijk in Nederlandse makelij kleiner, 3 oktober 2018. Centraal Bureau voor de Statistiek: Heerlen/Den Haag. https://www.cbs.nl/nl-nl/nieuws/2018/40/belangvan-het-vk-in-export-nederlandse-makelij-kleiner

CBS (2018c), Minder industrieel afval naar China, 29 november 2018. Centraal Bureau voor de Statistiek: Heerlen/Den Haag. https://www.cbs.nl/nl-nl/nieuws/2018/48/minder-industrieel-afvalnaar-china

CBS (2018d), Internationaliseringsmonitor editie Werkgelegenheid (2018-II), 28 juni 2018. Centraal Bureau voor de Statistiek: Heerlen/Den Haag. https://www.cbs.nl/nl-

nl/publicatie/2018/26/internationaliseringsmonitor-2018-tweede-kwartaal

CBS (2018e), 6 procent internationale alumni richt hier bedrijf op, 28 juni 2018. Centraal Bureau voor de Statistiek: Heerlen/Den Haag. https://www.cbs.nl/nl-nl/nieuws/2018/26/6-procent-

internationale-alumni-richt-hier-bedrijf-op

CBS (2018f), Invoer palmolie trekt weer aan, 19 maart 2018. Centraal Bureau voor de Statistiek: Heerlen/Den Haag. https://www.cbs.nl/nl-nl/nieuws/2018/12/invoer-palmolie-trekt-weer-aan

Dros, C. (2018, 22 juni), WUR zet in op digitaal aangestuurde voedselproductie. VMT: Wageningen. Geraadpleegd van https://www.vmt.nl/Nieuws/WUR_zet_in_op_digitaal_aangestuurde_voedselproductie180622121342

Duitsland. NMI-rapport 1568.14, NMI, Wageningen, 53 p. 
Europese Commissie (EC) (2018), Report from the European Commission to the Council and the European Parliament on the development of plant proteins in the European Union. Brussels, 22.11.2018, $\operatorname{COM}(2018) 757$ final

FiBL \& IFOAM, 2018. The World of Organic Agriculture 2018. Frick and Bonn.

Finanzen, 2018. https://www.finanzen.nl/grondstoffen/cacaoprijs

Fons-Rosen, C., Kalemli-Ozcan, S., Sorensen, B. E., Villegas-Sanchez, C., \& Volosovych, V. (2017). Foreign investment and domestic productivity: Identifying knowledge spillovers and competition effects (Tech. Rep.). National Bureau of Economic Research.

GF actueel, Belichte tomaat in opmars, 27-6-2017

Hagedoorn, J. and Cloodt, M. (2003), 'Measuring innovative performance: is there an advantage in using multiple indicators?' Research Policy, 32, 1365-1379.

Hosselet, L. (2017, 6 februari), Van het lab naar een bord is een lange weg voor kweekvlees, Trouw. Geraadpleegd van https://www.trouw.nl/groen/van-het-lab-naar-een-bord-is-een-lange-wegvoor-kweekvlees ae6d9867/

Kuipers, B., et al., Erasmus centre for urban port and transport economics (2018), Het Rotterdam effect: de impact van mainport Rotterdam op de Nederlandse economie, 18 december 2018. Erasmus, Rotterdam.

Kuypers, F., A. Lejour, O. Lemmers en P. Ramaekers, CPB/CBS (2012), Kenmerken van wederuitvoerbedrijven, 6 februari 2012. Centraal Bureau voor de Statistiek en Centraal Planbureau: Heerlen/Den Haag. https://www.cpb.nl/sites/default/files/publicaties/download/cpbachtergronddocument-kenmerken-van-wederuitvoerbedrijven.pdf

Langen Elles, Ongeveer 50 ha belichte teelt erbij, Goedemorgen paprika, 2014

Leten, B., Belderbos, R., Van Looy, B. (2016), Entry and technological performance in new technology domains: Technological opportunities, technological competition and technological relatedness. Journal of Management Studies, 53(8), 1257-1291.

Luesink, H.H., R. Postma, M.J. Smits, L. Van Schöll, en T.J. de Koeijer, 2016, Effect afzet mestverwerkingsproducten bij wettelijke status kunstmest of EG- meststof. Wageningen, LEI Wageningen UR (University \& Research centre), LEI Rapport 2016-034. 64 blz.; 6 fig.; 6 tab.; 45 ref.

Nagaoka, S., Motohashi, K. and A. Goto (2010), "Patent statistics as an innovation indicator" in Handbook of Economics of Innovation (eds. B. Hall and N. Rosenberg), pp. 1084-1127.

NOS (2017), Meer bloemen en kaas naar Japan dankzij nieuw handelsverdrag, https://nos.nl/artikel/2206649-meer-bloemen-en-kaas-naar-japan-dankzij-nieuwhandelsverdrag.html, 8 december 2017

Nuffic (2018), Incoming student mobility in Dutch higher education 2017/2018. https://test. nuffic.nl/enfetxihhvcw.html/internationalisation/facts-and-figures/publications-oninternational-student-mobility

Powell, W. en E. Ginaella (2010), "Collective invention and inventor networks" in Handbook of Economics of Innovation (eds. B. Hall and N. Rosenberg), pp. 575-601.

Ros, G, L. van Schöll en R. Postma (2014), Marktmogelijkheden voor mestproducten in het oosten van Schoonbrood, S. en M. Vancauteren (2015), Innovatie tijdens en na de recente crisis en de rol van internationalisering in: Internationaliseringsmonitor 2015, pp. 51-68, Centraal Bureau voor de Statistiek, Heerlen/Den Haag.

Smit, R. \& Wong, K.F. (2017), Ontwikkeling microdata dienstenhandel 2012-2016. Centraal Bureau voor de Statistiek. Heerlen/Den Haag.

Stefano Breschi, Francesco Lissoni; Mobility of skilled workers and co-invention networks: an anatomy of localized knowledge flows, Journal of Economic Geography, Volume 9, Issue 4, 1 July 2009, Pages 439-468.

Terluin, I.J., B.M. Kamphuis, D.A. Oudendag en M.G.A. van Leeuwen (2013). Voedselvoorziening in Nederland onder buitengewone crisisomstandigheden. LEI-rapport 2013-012. LEI Wageningen UR, Den Haag

Unilever (2017, 3 november), Unilever start bouw Global Foods Innovation Centre in Wageningen. Unilever: Rotterdam/Wageningen. Geraadpleegd van https://www. unilever.nl/news/persberichten/2017/unilever-start-bouw-global-foods-innovationcentre-in-wageningen.html

Unilever (2018, 29 augustus), Unilever's Global Foods Innovation Centre in Wageningen bereikt hoogste punt en ontvangt BREEAM Duurzaamheidscertificaat. Unilever: Rotterdam/Wageningen. 
Geraadpleegd van https://www.unilever.nl/news/overig-nieuws/2018/unilevers-global-foodsinnovation-centre-in-wageningen-bereikt-hoogste-punt-en-ontvangt-breeam-

duurzaamheidscertificaat.html

Unilever (z.d.). Onze R\&D-vestigingen. Unilever: Rotterdam/Wageningen. Geraadpleegd van https://www. unilever.nl/about/innovatie/unilever-research-prijs/

Vrolijk, H., P. W. Blokland, J. Helming, H. Luesink en H. Prins (2010), Economische gevolgen van een beperking van de veestapel; quick scan naar winnaars en verliezers. Rapport 2010-020, LEI Wageningen UR, Den Haag

VVD, CDA, D66, \& ChristenUnie (2017, 10 oktober), Regeerakkoord 2017 - 2021 'Vertrouwen in de toekomst'.

WiKi Groen Kennisnet, Tomaat - Beeldenbank - Global site 2018

WUR/CBS (2018), De Nederlandse landbouwexport 2017, 19 januari 2018. https://www.cbs.nl/nl-

nl/publicatie/2018/03/de-nederlandse-landbouwexport-2017

Bedrijveninformatienet, 2017. Bedrijveninformatienet, Wageningen Economic research 


\title{
Bijlage 1 Lijst van auteurs
}

\author{
Hoofdstuk 1 \\ Mark Dolman \\ Gerben Jukema \\ Pascal Ramaekers

\section{Hoofdstuk 2} \\ Pascal Ramaekers \\ Gerben Jukema \\ Marc Ruijs \\ Mark Dolman

\section{Hoofdstuk 3} \\ Jan Benninga (snijbloemen en tomaten) \\ Peter van Horne (consumptie-eieren) \\ Jakob Jager (kaas) \\ Bas Janssens (bevroren aardappelproducten) \\ Ruud van der Meer (appels) \\ Marc Ruijs (landbouwgerelateerde goederen) \\ Pepijn Smit (boomkwekerij) \\ Rob Stokkers (bloembollen) \\ Arjan Wisman (varkensvlees)
}

\section{Hoofdstuk 4}

Pascal Ramaekers

Gerben Jukema

Oscar Lemmers

Henk van Logtestijn

\section{Hoofdstuk 5}

Pascal Ramaekers

Roos Smit

Rik van Roekel

Mark Vancauteren

Dennis Cremers

Lico Hoekema

Marius Reitsema

Wim de Rooij

\section{Hoofdstuk 6}

Siemen van Berkum

Petra Berkhout 


\section{Bijlage 2 Dataverantwoording}

\section{B2.1 Berekeningswijze raming Nederlandse handel in landbouwgoederen}

Ten tijde van de uitgifte van deze publicatie zijn de definitieve cijfers voor 2018 nog niet voorhanden. Daarom is een raming vereist van de ontbrekende maanden. Dat is gedaan voor alle databronnen.

\section{Bron CBS}

De eerst tien maanden zijn gerealiseerde cijfers. Deze worden opgeteld bij een tweemaandenschatting. Over november en december zijn ten tijde van deze publicatie nog geen cijfers bekend. De schatting van deze maanden is gebaseerd op de procentuele ontwikkeling in de eerste tien maanden van 2018 ten opzichte van 2017 en de realisaties in november en december van 2017.

\section{Bron Eurostat/Comext}

Voor de berekeningen van het belang van Nederland in de Duitse import zijn cijfers van Eurostat/Comext nodig en gebruikt. Deze zijn nodig om landen binnen Europa met elkaar te kunnen vergelijken volgens één en dezelfde definitie van export en import. Hierbij zijn cijfers gebruikt van alleen de eerste negen maanden van 2018, omdat de overige drie maanden niet beschikbaar waren ten tijde van het onderzoek. Om naar een geschat jaartotaal te komen, zijn de resterende drie maanden geschat op dezelfde manier als hierboven is beschreven bij de CBS-cijfers.

\section{Bron Destatis}

Voor de raming van de cijfers over de handel van de Zuid-Duitse deelstaten met Nederland zijn cijfers gebruikt van Destatis. Ook hier zijn gerealiseerde cijfers tot en met september 2018 gebruikt, waarbij de andere maanden zijn geschat. Ook hier is dezelfde systematiek gebruikt die eerder is omschreven.

\section{Bron Comtrade}

Verder zijn cijfers van de Verenigde Naties (Comtrade) gebruikt om de Nederlandse handel te vergelijken met andere landen uit de rest van de wereld. Hierbij zijn beschikbare cijfers gebruikt van het volledige jaar 2017. Omdat er, zoals elk jaar het geval is, voor dit jaar (2017) een aantal landen nog geen handelscijfers had ingeleverd, is op basis van 2015 en 2016 een schatting van deze landen gemaakt om 2017 aan te vullen. Dit is alleen van toepassing op de handel in agrarische producten. De in de hoofdtekst cijfers van de genoemde landen zijn gerealiseerde cijfers. Van 2018 waren ten tijde van deze publicatie nog onvoldoende cijfers bekend om een goede vergelijking van alle landen in de wereld mogelijk te maken.

Het CBS levert op verschillende tijdstippen en volgens de voor deze bronnen geëigende definities en voorschriften de Nederlandse cijfers aan aan Eurostat en de Verenigde Naties.

\section{B2.1.1 Definitie in landbouwgoederen}

Wat precies onder landbouwhandel of agrarische handel valt, is een definitiekwestie. Wageningen Economic Research heeft samen met het ministerie van Landbouw, Natuur en Voedselkwaliteit (LNV) en het CBS bepaald welke producten wel en niet onder de agrarische sector vallen. Deze lijst is zo veel mogelijk in overeenstemming met de definitie die ook de Europese Commissie (EC) gebruikt. Het verschil met de EC is dat zowel vis als houtproducten wel opgenomen zijn in de hier gebruikte definitie en deze twee productgroepen door de EC afzonderlijk worden gerapporteerd. De agrarische handel zoals gebruikt in deze publicatie omvat de eerste 24 hoofdstukken van de internationale handelsstatistieken, plus een aantal agrarische producten uit overige hoofdstukken volgens de Gecombineerde Nomenclatuur-coderingssystematiek (GN) (zie voor een volledige lijst: WUR/CBS, 2018). Door gebruik te maken van de Gecombineerde Nomenclatuur-coderingssystematiek kunnen 
nagenoeg dezelfde productgroepen worden betrokken van het CBS, Eurostat/Comext en de Verenigde Naties/Comtrade. Voor wat betreft de specifieke producten in hoofdstuk 3 zijn de gebruikte figuren gebaseerd op de GN-coderingen in tabel B2.1.

Tabel B2.1 Lijst van GN-codes per uitgelichte productgroep in hoofdstuk 3.

\begin{tabular}{ll} 
Product(groep) & GN-codes \\
\hline Appels & $08081010 / 08081080$ \\
\hline Bevroren aardappelen & 20041 \\
\hline Bloembollen & 06011 \\
\hline Boomkwekerijproducten & $06022020 / 06022030 / 06022080 / 06022090 / 06024000 / 06029041 / 06029045 / 06029046 / 060$ \\
\hline Eieren, consumptie (exclusief & $04072100 / 04072910 / 04072990 / 04079010 / 04079090$ \\
\hline broedeieren) & \\
\hline Kaas & 0406 \\
\hline Snijbloemen & 0603 \\
\hline Tomaten & 0702 \\
\hline Varkensvlees & 0203 \\
\hline
\end{tabular}

\section{Landbouwdefinitie Destatis ten behoeve van de (Zuid-Duitse) deelstaten}

Bij Destatis, die ook import- en exportcijfers per deelstaat publiceert, is gekozen om de agrarische handel te definiëren volgens de EGW (Ernährungswirtschaft und der Gewerblichen Wirtschaft). Er zijn 230 verschillende EGW-codes. Voor de definitie 'agrarisch' zijn codes in tabel B2.2 als agrarisch bestempeld. 
Tabel B2.2 Lijst van EGW-codes die zijn aangemerkt als landbouwgoederen.

\begin{tabular}{|c|c|}
\hline EGW-code & Duitse omschrijving \\
\hline EGW101 & Pferde \\
\hline EGW102 & Rinder \\
\hline EGW103 & Schweine \\
\hline EGW105 & Schafe \\
\hline EGW107 & Hausgeflügel \\
\hline EGW109 & Lebende Tiere, a.n.g. \\
\hline EGW201 & Milch, Milcherzeugnisse ausgen. Butter u. Käse \\
\hline EGW202 & Butter, Fettstoffe der Milch, Milchstreichfette \\
\hline EGW203 & Käse \\
\hline EGW204 & Fleisch u. Fleischwaren \\
\hline EGW206 & Fische, Krebstiere, Weichtiere, Zubereitungen dar. \\
\hline EGW208 & Tierische Öle und Fette \\
\hline EGW209 & Eier, Eiweiß, Eigelb \\
\hline EGW211 & Fischmehl, Fleischmehl u.ä. Erzeugnisse \\
\hline EGW219 & Nahrungsmittel tierischen Ursprungs, a.n.g. \\
\hline EGW301 & Weizen \\
\hline EGW302 & Roggen \\
\hline EGW303 & Gerste \\
\hline EGW304 & Hafer \\
\hline EGW305 & Mais \\
\hline EGW308 & Sorghum, Hirse u. sonst. Getreide, ausgen. Reis \\
\hline EGW309 & Reis u. Reiserzeugnisse \\
\hline EGW310 & Getreideerzeugnisse, ausgen. Reiserzeugnisse \\
\hline EGW315 & Backwaren u.a. Zubereitungen aus Getreide \\
\hline EGW316 & Malz \\
\hline EGW320 & Saat- u. Pflanzgut, ausgen. Ölsaaten u.a. \\
\hline EGW325 & Hülsenfrüchte \\
\hline EGW335 & Grün- u. Raufutter \\
\hline EGW340 & Kartoffeln und Kartoffelerzeugnisse \\
\hline EGW345 & Gemüse u. sonstige Küchengewächse, frisch \\
\hline EGW350 & Frischobst, ausgenommen Südfrüchte \\
\hline EGW355 & Südfrüchte \\
\hline EGW360 & Schalen- u. Trockenfrüchte \\
\hline EGW370 & Gemüsezubereitungen u. Gemüsekonserven \\
\hline EGW372 & Obstzubereitungen u. Obstkonserven \\
\hline EGW375 & Obst- u. Gemüsesäfte \\
\hline EGW377 & Kakao und Kakaoerzeugnisse \\
\hline EGW379 & Gewürze \\
\hline EGW381 & Zuckerrüben, Zucker u. Zuckererzeugnisse \\
\hline EGW383 & Ölfrüchte \\
\hline EGW385 & Pflanzliche Öle u. Fette \\
\hline EGW389 & Ölkuchen \\
\hline EGW393 & Kleie, Abfallerz. z. Viehfütterung u. Futtermittel \\
\hline EGW395 & Nahrungsmittel pflanzlichen Ursprungs, a.n.g. \\
\hline EGW396 & Lebende Pflanzen u. Erzeugnisse d. Ziergärtnerei \\
\hline EGW401 & Hopfen \\
\hline EGW402 & Kaffee \\
\hline EGW403 & Tee u. Mate \\
\hline EGW411 & Rohtabak u. Tabakerzeugnisse \\
\hline EGW421 & Bier \\
\hline EGW423 & Branntwein \\
\hline EGW425 & Wein \\
\hline EGW502 & Chemiefasern, Seidenraupenkokons u. Abfälle \\
\hline EGW503 & Wolle u.and.Tierhaare, roh u.bearb., Reißwolle \\
\hline EGW504 & Baumwolle,roh u.bearb., Reißbaumwolle, Abfälle \\
\hline EGW505 & Flachs,Hanf,Jute,Hartfasern u.sonst.pfl.Spinnstf. \\
\hline EGW506 & Abfälle von Gespinstwaren, Lumpen \\
\hline EGW507 & Felle zu Pelzwerk, roh \\
\hline EGW508 & Felle u. Häute, roh, a.n.g. \\
\hline
\end{tabular}




\section{Landbouwgerelateerde goederen}

De in deze publicatie gebruikte cijfers betreffen de handel in landbouwgoederen. Dit zijn zowel onbewerkte (primaire) als bewerkte (secundaire) goederen. Daarnaast zijn er (niet eetbare) goederen die geproduceerd worden ten behoeve van de landbouwsectoren in binnen- of buitenland, de zogenaamde tertiaire of landbouwgerelateerde goederen. In deze publicatie zijn alleen de producten geselecteerd die direct kunnen worden toegeschreven aan de agrarische sectoren. Het gebruik van drones in de agrarische sector kan bijvoorbeeld momenteel niet inzichtelijk worden gemaakt in de handelscijfers, omdat drones door allerlei sectoren kunnen worden ingezet. Daarom zijn deze niet meegenomen in de in deze uitgave gepubliceerde cijfers. In deze uitgave zijn de volgende landbouwgerelateerde goederen onderscheiden:

Tabel B2.3 Lijst van GN-goederencodes die zijn aangemerkt als landbouwgerelateerde goederen.

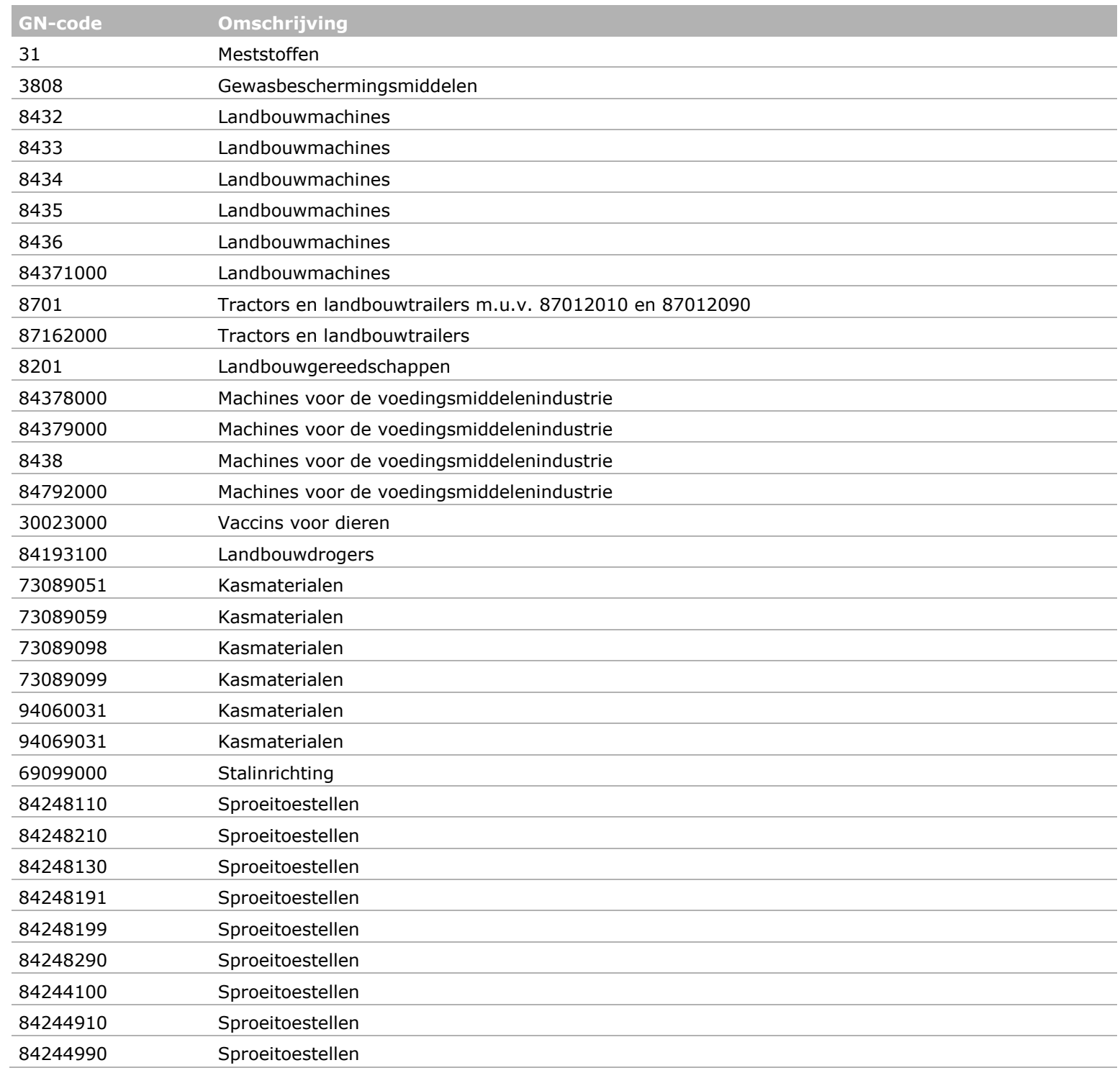

\section{B2.1.2 Asymmetrie in de handelsstatistieken}

Handelscijfers waarvan wellicht wordt verwacht dat ze gelijk aan elkaar zouden moeten zijn, verschillen van elkaar. Zo is misschien al wel opgevallen dat de exportwaarde die Nederland naar Duitsland rapporteert niet precies gelijk is aan de import die Duitsland rapporteert over de goederen die uit Nederland zijn geïmporteerd. Dat heeft te maken met zowel handelsasymmetrie als met (bewuste) conceptuele verschillen. 
Asymmetrie in de handelsstatistieken tussen landen komt wereldwijd vaak voor en heeft betrekking op een afwijking in de opgave tussen, in dit geval, Duitse en Nederlandse bedrijven met betrekking tot dezelfde goederenstroom. Dat kan worden veroorzaakt door een foutieve opgave door een bedrijf of een interpretatieverschil door een bedrijf ten aanzien van het land van herkomst of de bestemming. Ook kan handelsasymmetrie ontstaan doordat specifieke goederenstromen op een afwijkende manier worden geschat, indien dat nodig is.

Door bewuste conceptuele keuzes bij statistiekbureaus kunnen er nog meer verschillen ontstaan in de rapportages. Zo worden door het CBS geen quasi-doorvoerstromen gepubliceerd, maar door Eurostat wel. Is de bron van de data Eurostat, dan is die quasi-doorvoerstroom wel voor alle landen meegenomen. Een ander belangrijk verschil is dat Duitsland bij de importcijfers niet de import uit Nederland meeneemt indien bekend is dat de goederen in een derde land zijn gemaakt (het land van oorsprongprincipe bij Destatis versus het land van herkomstprincipe bij het CBS of Eurostat).

Bij de cijfers over de deelstaten moet het volgende gerealiseerd worden: Nederlandse producten kunnen bijvoorbeeld gekocht en ingevoerd worden door een bedrijf in Hamburg, om vervolgens te worden doorverkocht aan een bedrijf in de deelstaat München. Deze laatste handelsstroom - de goederenhandel tussen Duitse deelstaten - is niet in deze cijfers opgenomen. Het gaat dus om de eerste Duitse regio (bij de import uit Nederland) of de laatste Duitse regio (bij de export naar Nederland) die handelt met Nederland. In welke Duitse regio de goederen uiteindelijk terechtkomen, of uit welke Duitse regio ze oorspronkelijk afkomstig zijn, komt niet in de cijfers.

\section{Waarom niet overal ook volumes aangeven?}

De gepubliceerde cijfers betreffen vooral waarden. Inzicht in volume is moeilijker te geven, omdat er veel verschillende eenheden van een goederensoort zijn, die zich moeilijk laten optellen. Veelal worden kilogrammen gebruikt, maar er zijn nog 33 andere eenheden, zoals stuks en liters, die in de handelsstatistieken worden gebruikt. Een ander punt is dat de waardecijfers in de statistiek Internationale handel in goederen (IHG) traditioneel van hogere kwaliteit zijn dan de hoeveelheidscijfers.

Om toch onderscheid te kunnen maken tussen prijs en volume, wordt op de afdeling Nationale Rekeningen (zie begrippenlijst) bij het CBS gebruikgemaakt van betrouwbare meso- en macroramingen. Deze ramingen worden elk kwartaal gemaakt, bijvoorbeeld als onderdeel van de raming van de economische groei in Nederland. Ze geven een nauwkeurig beeld van de volume- en prijsmutaties in de in- en uitvoer van diverse productgroepen, waaronder landbouwgoederen. De landbouwcijfers zijn echter niet beschikbaar op een laag detailniveau.

\section{B2.2 Exportverdiensten}

In deze publicatie is daarnaast ook gebruikgemaakt van cijfers over exportverdiensten die het CBS heeft berekend ten aanzien van de bijdrage van de landbouwexport aan het Nederlandse bbp. Hierbij wordt gebruikgemaakt van waardeketenanalyse. Een internationale waardeketen omvat alle activiteiten - in meer dan één land - die nodig zijn om een product of dienst vanuit de conceptfase via de verschillende productiefases bij eindgebruikers te bezorgen en voor de verwerking na gebruik. Waardeketenanalyse wordt gedaan op basis van input-outputtabellen (zie begrippenlijst) van de Nationale Rekeningen van het CBS.

\section{B2.2.1 Negatieve bijstellingen in 2017 en eerder}

De definitieve cijfers voor 2017 en eerdere jaren ten aanzien van de handel in landbouwgoederen zijn fors lager dan eerder aangenomen. De belangrijkste oorzaak is methodologisch van aard. Om de kwaliteit van de jaarcijfers hoog te houden, zijn de bijschattingen (van niet ontvangen opgaven) en imputaties (voor jaaraangevers) anders verwerkt (er wordt bijvoorbeeld anders rekening gehouden met bedrijven die geen handel hebben bedreven). Deze aanpassingen hebben er grotendeels toe geleid dat de definitieve uitkomsten van 2017 flink naar beneden zijn bijgesteld. Om voor de gebruiker een zo zuiver mogelijk beeld te geven, is voor de statistiek IHG afgeweken van het eigen 
publicatiebeleid (ten aanzien van definitieve jaren) en zijn tegelijkertijd de cijfers over 2016 (eveneens naar beneden) bijgesteld. Daarmee blijft de ontwikkeling tussen 2017 en 2016 reëel. In het totale beeld zien we dat in 2017 vooral de invoer lager is en de uitvoer niet. Dit komt doordat het effect van de bijschattingen bij de invoer groter is dan bij de uitvoer. Daarnaast zijn bij de uitvoer enkele grote incidentele aanpassingen van bedrijven verwerkt die het exportcijfer omhoog stuwden.

Het is niet onlogisch dat de cijfers van landbouwgerelateerde bedrijven meer dan gemiddeld zijn bijgesteld. Vooral omdat in de landbouw meer dan gemiddeld kleine bedrijven actief zijn (meer jaaraangevers). Daarnaast wordt er bij het imputeren van non-respons op basis van een SBI (hoofdactiviteit in het handelsregister) een schatting gemaakt van de handelsactiviteit. Wanneer de jaaropgaven zijn ontvangen, worden de geschatte waarden van deze bedrijven overschreven. Juist bij de landbouw zullen deze overschrijvingen ertoe leiden dat de handel verdeeld wordt over landbouw én de nevenactiviteiten (niet-landbouwgerelateerde handel).

\section{Extra negatieve bijstellingen bij de exportverdiensten}

De IHG-cijfers dienen als input voor de berekening van de exportverdiensten. Daarom zijn de exportverdiensten (in 2017 en eerder) ook lager dan verwacht. Daarnaast is er sprake van een tweede grote negatieve bijstelling - deze is nog groter dan bovenstaande bijstelling. Dit heeft te maken met een revisie van de Nationale Rekeningen over dit kalenderjaar (2018). Een NR-revisie wordt conform het revisiebeleid van het CBS eens in de vijf jaar uitgevoerd. De revisie betekent dat er een nieuwe (niveau)raming van de Nationale Rekeningen voor verslagjaar 2015 en latere jaren beschikbaar komt. Daarbij worden nieuwe bronnen, methoden en concepten doorgevoerd in de nationale rekeningen, zodat het beeld van de Nederlandse economie weer optimaal aansluit bij alle onderliggende statistieken, bronnen en internationale richtlijnen voor het samenstellen van de nationale rekeningen.

De waarde van de landbouwexport wordt per product geijkt op de Nationale Rekeningen. Vervolgens wordt gekeken welke bedrijfstak deze producten exporteert en hoeveel toegevoegde waarde iedere bedrijfstak overhoudt aan de export van de landbouwproducten. Ook deze informatie komt uit de Nationale Rekeningen. Een revisie van dit stelsel kan dus leiden tot een andere schatting van de toegevoegde waarde van de landbouwexport.

Na de revisie is de verhouding toegevoegde waarde ${ }^{18}$ per euro productie (voor Nederland, als geëxporteerd Nederlands product of als wederuitvoer) voor de voedingsmiddelenindustrie en de groothandel lager dan voorheen. Bij een gelijke export door deze bedrijfstakken is de schatting van de toegevoegde waarde van deze export dan minder dan voor de revisie. De voedingsmiddelenindustrie speelt een grote rol in de export van in Nederland geproduceerde landbouwproducten. De groothandel doet dat ook en is daarnaast leidend in de wederuitvoer van landbouwproducten. Door de bijstellingen in deze bedrijfstakken gaat de totale toegevoegde waarde van de landbouwexport omlaag.

\section{B2.3 Internationale landbouwstudenten}

In dit onderzoek is gebruikgemaakt van de Onderwijsstatistieken van het CBS. Deze zijn aangevuld met gegevens uit het Algemene Bedrijfsregister (ABR) om de bedrijfsoprichtingen te achterhalen van wo-alumni van Nederlandse universiteiten. In het onderzoek is ook gebruikgemaakt van onderwijsinformatie van het agentschap DUO (Dienst Uitvoering Onderwijs van het ministerie van Onderwijs, Cultuur en Wetenschap) en van het Sociaal Statistische Bestand van het CBS inzake arbeidsmarktgegevens.

Voor dit onderzoek zijn alumni van Nederlandse universiteiten door de tijd gevolgd: wonen ze nog in Nederland, werken ze (nog) in Nederland en hebben ze een bedrijf opgericht in Nederland? Daarbij is gebruikgemaakt van inschrijvingen in het BRP (Basisregistratie Personen, ministerie van Binnenlandse Zaken). Internationale alumni die zich tijdens hun studie nooit in het BRP hebben ingeschreven, konden in het onderzoek daardoor niet worden meegenomen. Niet-internationale alumni stonden vrijwel altijd ingeschreven, internationale alumni voor ongeveer drie kwart. Duitse studenten schrijven

\footnotetext{
${ }^{18}$ Toegevoegde waarde inclusief het saldo van productgebonden belastingen en subsidies.
} 
zich relatief weinig in (circa de helft). Dat kan bijvoorbeeld zijn omdat ze in Duitsland kunnen blijven wonen indien de Nederlandse universiteit zich op korte afstand bevindt. Ervan uitgaande dat nietinschrijvers minder vaak actief worden op de Nederlandse arbeidsmarkt dan wel-inschrijvers, betekent dit een overschatting van de werkgelegenheids- en oprichtingspercentages van deze groep. De nietinschrijvers (niet in dit onderzoek) richten namelijk ook bedrijven op, maar dat zijn er vermoedelijk procentueel minder dan bij de wel-inschrijvers. Om overlap te voorkomen (iemand kan afstuderen met een bachelor en het jaar erop met een master), is voor de grafieken met meerdere studiejaren 'ontdubbeld', zodat unieke gediplomeerden overblijven.

Zie voor meer informatie de Internationaliseringsmonitor, editie 'Werkgelegenheid' (CBS, 2018).

\section{B2.4 Innovatie en R\&D in de agribusiness}

In opdracht van Eurostat vraagt het CBS tweejaarlijks de innovatie-enquête (Community Innovation Survey, CIS) aan bedrijven met tien of meer werkzame personen uit. Het CBS verstuurt de enquête naar meer sectoren dan vanuit Eurostat verplicht is. De enquêtering gebeurt in de oneven jaren en is gericht op de afgelopen twee jaren vóór het jaar van uitvraag.

Het CBS vraagt jaarlijks de R\&D-enquête uit. Hiermee probeert het CBS inzicht te krijgen in de uitgaven en arbeidsjaren die bedrijven en instellingen besteden aan onderzoek en ontwikkeling. De uitvraag is altijd gericht op het jaar vóór de enquêtering. De totale uitgaven van bedrijven en overheid samen komen al enkele jaren neer op zo'n $2 \%$ van het bbp.

Deze twee bronnen samen geven een consistent beeld over de uitgaven van Nederlandse bedrijven en instellingen aan technologische innovatie en laten bovendien uitsplitsingen naar bedrijfskenmerken (waaronder sector) toe. Zo is het mogelijk om een eenduidig beeld te vormen over onderzoek, ontwikkeling en innovatie binnen bijvoorbeeld de agribusiness. In tabel B2.4 staan de bedrijfstakken die in deze publicatie tot de agribusiness worden gerekend. 
Tabel B2.4 Definitie agribusiness: lijst van bedrijfstakken.

\begin{tabular}{|c|c|}
\hline SBI & Omschrijving \\
\hline $01 x x$ & Landbouw, jacht en dienstverlening voor de landbouw en jacht \\
\hline $03 x x$ & Visserij en het kweken van vis en schaaldieren \\
\hline $10 x x$ & Vervaardiging van voedingsmiddelen \\
\hline $11 x x$ & Vervaardiging van dranken \\
\hline 2015 & Vervaardiging van kunstmeststoffen en stikstofverbindingen \\
\hline 2020 & Vervaardiging van verdelgingsmiddelen en overige landbouwchemicaliën \\
\hline 2830 & Vervaardiging van machines en werktuigen voor de land- en bosbouw \\
\hline 2893 & Vervaardiging van machines voor de productie van voedings- en genotmiddelen \\
\hline 4611 & $\begin{array}{l}\text { Handelsbemiddeling in landbouwproducten, levende dieren en grondstoffen voor textiel en } \\
\text { voedingsmiddelen }\end{array}$ \\
\hline 4617 & Handelsbemiddeling in voedings- en genotmiddelen \\
\hline 46211 & Groothandel in granen \\
\hline 46212 & Groothandel in zaden, pootgoed en peulvruchten \\
\hline 46213 & Groothandel in hooi, stro en ruwvoeder \\
\hline 46214 & Groothandel in meng- en krachtvoeder \\
\hline 46215 & Groothandel in veevoeder (geen ruw-, meng- en krachtvoeder) \\
\hline 46216 & Groothandel in ruwe plantaardige en dierlijke oliën en vetten en oliehoudende grondstoffen \\
\hline 46218 & Groothandel in akkerbouwproducten en veevoeder algemeen assortiment \\
\hline 46219 & Groothandel in overige akkerbouwproducten \\
\hline 4622 & Groothandel in bloemen en planten \\
\hline 46231 & Groothandel in levend vee \\
\hline 46232 & Groothandel in huisdieren, siervissen, siervogels en wilde dieren \\
\hline 46311 & Groothandel in groenten en fruit \\
\hline 46312 & Groothandel in consumptieaardappelen \\
\hline 4632 & Groothandel in vlees en vleeswaren en in wild en gevogelte (niet levend) \\
\hline 46331 & Groothandel in zuivelproducten en spijsoliën en -vetten \\
\hline 46332 & Groothandel in eieren \\
\hline 4634 & Groothandel in dranken (geen zuivel) \\
\hline 4636 & Groothandel in suiker, chocolade en suikerwerk \\
\hline 4637 & Groothandel in koffie, thee, cacao en specerijen (geen ruwe) \\
\hline 46381 & Groothandel in snacks \\
\hline 46382 & Groothandel in vis en schaal- en weekdieren \\
\hline 46383 & Gespecialiseerde groothandel in overige voedings- en genotmiddelen (rest) \\
\hline 46384 & Groothandel in bakkerijgrondstoffen \\
\hline 46389 & $\begin{array}{l}\text { Gespecialiseerde groothandel in overige grondstoffen en halffabricaten voor de } \\
\text { voedingsmiddelenindustrie (rest) }\end{array}$ \\
\hline 4639 & Groothandel in voedings- en genotmiddelen algemeen assortiment \\
\hline 4661 & Groothandel in landbouwmachines, werktuigen en tractors \\
\hline 46682 & Groothandel in machines voor de voedings- en genotmiddelenindustrie \\
\hline 4711 & Supermarkten en dergelijke winkels met een algemeen assortiment voedings- en genotmiddelen \\
\hline 4721 & Winkels in aardappelen, groenten en fruit \\
\hline 47221 & Winkels in vlees en vleeswaren \\
\hline 47222 & Winkels in wild en gevogelte \\
\hline 4723 & Winkels in vis \\
\hline 47241 & Winkels in brood en banket \\
\hline 47242 & Winkels in chocolade en suikerwerk \\
\hline 4725 & Winkels in dranken \\
\hline 47291 & Winkels in kaas \\
\hline 47292 & Winkels in natuurvoeding en reformartikelen \\
\hline 47293 & Winkels in buitenlandse voedingsmiddelen \\
\hline 47299 & Gespecialiseerde winkels in overige voedings- en genotmiddelen (rest) \\
\hline 47811 & Markthandel in aardappelen, groenten en fruit \\
\hline 47819 & Markthandel in overige voedings- en genotmiddelen \\
\hline 47891 & Markthandel in bloemen, planten, zaden en tuinbenodigdheden \\
\hline 71201 & Keuring en controle van agrarische producten en voedingsmiddelen \\
\hline 72111 & Biotechnologisch speur- en ontwikkelingswerk op het gebied van agrarische producten en processen \\
\hline 72191 & Speur- en ontwikkelingswerk op het gebied van landbouw en visserij (niet biotechnologisch) \\
\hline 7731 & Verhuur en lease van landbouwmachines en -werktuigen \\
\hline 82991 & Veilingen van landbouw-, tuinbouw- en visserijproducten \\
\hline
\end{tabular}




\section{B2.5 Dienstenhandel door de agribusiness}

De gepresenteerde cijfers zijn gebaseerd op de CBS-statistiek Internationale handel in diensten. Met deze statistiek worden elk kwartaal gegevens gepubliceerd over de invoer en uitvoer van diensten door in Nederland gevestigde bedrijven en personen, uitgesplitst naar diverse dienstensoorten en landen. De dienstensoorten die vanaf 2014 door alle EU-landen worden gehanteerd, zijn gebaseerd op afspraken die zijn vastgelegd in de 'Balance of Payments Manual 6' (BPM6).

\section{B2.6 Nederlandse landbouwindustrie buiten de EU}

De getoonde cijfers komen voort uit de CBS-statistiek 'Outward FATS' (Foreign Affiliate Trade Statistics). Deze tabel gaat over de omzet, werkzame personen en het aantal buitenlandse dochterondernemingen buiten de EU-zone waarover een Nederlandse institutionele eenheid zeggenschap heeft.

De nationaliteit van een onderneming wordt bepaald door wereldwijd te beoordelen welke institutionele eenheid controle heeft over de ondernemingsgroep. Voor de gegevens in deze tabel geldt dat de Ultimate Controlling Institutional unit (UCI) van de ondernemingengroep in Nederland ligt.

Bij de 'Inward FATS', het omgekeerde van de 'Outward FATS', gaat het om een beschrijving van de activiteiten van bedrijven in Nederland waarover een institutionele eenheid in het buitenland zeggenschap heeft.

\section{B2.7 De biologische Agro/Food-sector}

In Nederland zet 'Skal Biocontrole' zich als onafhankelijk toezichthouder in voor aantoonbare betrouwbaarheid van biologische producten in Nederland. De aanduiding 'biologisch' is binnen de EU slechts op landbouwproducten en levensmiddelen toegestaan wanneer deze aantoonbaar voldoen aan de daarvoor geldende wettelijke eisen, vastgelegd in de EU-verordeningen nr. 834/2007 en nr. 889/2008. Aantoonbaar biologisch wil zeggen: gecontroleerd en gecertificeerd door een door de EU erkende controle-instantie. Skal vertaalt de regelgeving voor Nederland naar een uitvoerbaar toezichtsysteem. De Europese overheid bepaalt de regels, de circa 4 duizend gecertificeerde bioondernemers leven deze na en Skal controleert hierop.

Het CBS ontvangt jaarlijks van Skal biocontrolegegevens van de gecertificeerde bedrijven. Deze worden naar type activiteit geteld en jaarlijks aan Eurostat geleverd. De gegevens over andere EUlidstaten zijn afkomstig uit de Eurostat-database New Cronos.

\section{B2.8 Gebruik van duurzame agrogrondstoffen}

Er is gebruikgemaakt van rapportages van verschillende organisaties. Deze zijn voor elke grondstof verschillend:

- Palmolie: MVO - de ketenorganisatie voor oliën en vetten (www.mvo.nl)

- Soja: Nevedi (Nederlandse Vereniging Diervoederindustrie, www.nevedi.nl)

- Hout: Stichting Probos (www.probos.nl)

- Cacao: CBS (MDA 2016)

- Koffie: KNVKT (Koninklijke Nederlandse Vereniging voor Koffie en Thee, www.knvkt.nl)

- Kweekvis: CBS (MDA 2016)

- Verse groenten en fruit: CBS (MDA 2016) 


\section{Bijlage 3 Begrippenlijst}

\section{B3.1 Handel}

\section{Uitvoerwaarde (export)}

De waarde van de door ingezetenen aan het buitenland geleverde goederen volgens de statistieken van de internationale handel. Dit is de waarde, inclusief vracht- en verzekeringskosten, tot aan de Nederlandse grens. Dit kunnen goederen zijn die in Nederland zijn voortgebracht of vervaardigd, maar ook aanvankelijk ingevoerde goederen. Tot de uitvoer behoren ook tijdelijk uitgevoerde goederen die in opdracht van een ingezetene in het buitenland een behandeling ondergaan (passieve loonveredeling).

\section{Quasi-doorvoer}

Quasi-doorvoer betreft invoer van goederen van buitenlandse makelij die na aankomst in Nederland niet of nauwelijks een bewerking ondergaan en daarna weer worden doorgevoerd naar het buitenland. De goederen zijn tijdens het gehele verblijf in Nederland eigendom van een buitenlands bedrijf (in tegenstelling tot bij wederuitvoer). De quasi-doorvoer is geen onderdeel van de Nederlandse cijfers over de Nederlandse handel (Bron: CBS), wel bij de Europese cijfers over de Nederlandse handel (Bron: Eurostat).

\section{Uitvoer van goederen van Nederlandse makelij}

Uitvoer van goederen van Nederlandse makelij betreft uitvoer na productie in Nederland of uitvoer na significante bewerking van goederen van buitenlandse makelij (waarbij wordt gekeken in hoeverre de statistische goederencode van het goed al dan niet sterk is veranderd). Wederuitvoer en uitvoer van goederen van eigen makelij vormen samen de totale Nederlandse uitvoercijfers.

\section{Wederuitvoer}

Wederuitvoer betreft invoer van goederen van buitenlandse makelij die na aankomst in Nederland niet of nauwelijks een bewerking ondergaan en daarna weer worden doorgevoerd naar het buitenland. De goederen zijn tijdens het verblijf in Nederland (tijdelijk) eigendom van een Nederlands bedrijf (in tegenstelling tot bij quasi-doorvoer).

\section{Invoerwaarde (import)}

De waarde van door het buitenland aan ingezetenen geleverde goederen volgens de statistieken van de internationale handel. Bij invoer uit EU-landen is dit de waarde van de goederen, inclusief vrachten verzekeringskosten, tot aan de Nederlandse grens. Bij invoer uit niet-EU-landen is dit de waarde, inclusief vracht- en verzekeringskosten, tot aan de buitengrens van de Europese Unie.

De invoer van goederen betreft alle goederen die voor gebruik of verbruik in het economisch vrije verkeer van Nederland zijn gebracht. Dit is het geval wanneer de invoerheffingen en nationale belastingen zijn voldaan. Tot de invoer van goederen behoren ook:

- tijdelijk ingevoerde goederen die in ons land, in opdracht van een niet-ingezetene, een behandeling ondergaan (actieve loonveredeling);

- goederen uit niet-EU-landen die via een entrepot in het economisch vrije verkeer van Nederland komen;

- ingevoerde goederen die, zonder enige bewerking te hebben ondergaan, weer worden uitgevoerd (wederuitvoer).

\section{Handelsbalans}

De handelsbalans geeft het saldo aan tussen uitvoerwaarde en invoerwaarde, beide gemeten in euro. Meer uitvoer dan invoer geeft een handelsoverschot, omgekeerd wordt gesproken van een handelstekort. 


\section{B3.2 Internationale landbouwstudenten}

\section{Internationale wo-alumni}

Wo-alumni (afgestudeerden van een Nederlandse universiteit) met een niet-Nederlandse nationaliteit en een buitenlandse of onbekende vooropleiding.

\section{Niet-internationale wo-alumni}

Wo-alumni (afgestudeerden van een Nederlandse universiteit) met een Nederlandse nationaliteit en wo-alumni met een niet-Nederlandse nationaliteit en een Nederlandse vooropleiding.

\section{Wo-alumni}

Studenten die met goed gevolg een afsluitend diploma in het wetenschappelijk onderwijs (wo) hebben behaald. De volgende diploma's worden onderscheiden: bachelor-, master-, doctoraal- en beroepsdiploma's. Als iemand in het wo in een studiejaar diploma's op meerdere niveaus heeft behaald (bijvoorbeeld een bachelor- en een masterdiploma), is in deze publicatie het diploma van het hoogste niveau meegenomen.

\section{Werkenden}

Het aantal mensen dat werk heeft in Nederland. Arbeid in het buitenland of overige arbeid, zoals freelancewerk, is buiten beschouwing gelaten.

\section{B3.3 Exportverdiensten}

\section{Bruto binnenlands product (bbp)}

Een maat voor de omvang van de economie. Deze wordt berekend uit de som van de waarde die door ondernemingen, huishoudens en overheden wordt toegevoegd aan de goederen en diensten die zij hebben moeten verbruiken om hun producten te kunnen maken. Deze som staat bekend als de toegevoegde waarde 'in basisprijzen'. Om tot het bbp 'in marktprijzen' te komen, wordt hierbij het saldo van productgebonden belastingen en subsidies én het verschil tussen toegerekende en afgedragen btw opgeteld.

\section{Input-outputanalyse}

Met input-outputanalyse worden onder andere de uitgaven aan primaire inputs en productiefactoren, zoals de kosten van goederen en diensten die niet in Nederland zijn geproduceerd (import), en de productiefactoren (arbeid, kapitaal, ondernemerschap) toegerekend aan de finale bestedingen (consumptie door huishoudens, consumptie door overheid, investeringen, export). Met de inputoutputanalyse worden daarnaast indirecte intermediaire leveringen tussen bedrijfstakken in beeld gebracht, waardoor afhankelijkheden in waardeketens zichtbaar kunnen worden gemaakt.

\section{B3.4 Innovatie en R\&D in de agribusiness}

\section{Agribusiness}

De agribusiness bestaat uit bedrijven die actief zijn in de landbouw, visserij en jacht, evenals gerelateerde sectoren, zoals de drank- en voedingsmiddelenindustrie. Ook bedrijven die onderzoek doen of zich bezig houden met dienstverlening ten behoeve van de landbouw, behoren tot de agribusiness. Tot slot worden op voedings- en drankmiddelen gerichte markt-, detail- en groothandels ook tot de agribusiness gerekend. Zie tabel B1.4 voor een gedetailleerd totaaloverzicht.

\section{Innovatie}

Het ontwikkelen van nieuwe of sterk verbeterde producten (productinnovatie) en/of het in gebruik nemen van nieuwe of sterk verbeterde productieprocessen (procesinnovatie). Daarnaast behoren ook organisatorische innovatie en marketinginnovatie tot het concept innovatie. Innovatie kan grofweg in twee hoofdtypen worden ingedeeld: technologische en niet-technologische innovatie. 
Technologische innovatie omvat productinnovatie en procesinnovatie, niet-technologische innovatie betreft organisatorische innovatie en marketinginnovatie. In de Oslo Manual van de OESO worden de volgende typen innovatie onderscheiden:

1. Productinnovatie: het bedrijf heeft één of meerdere nieuwe of sterk verbeterde producten geïntroduceerd. Dit kunnen goederen of diensten zijn die nieuw voor de markt zijn of alleen nieuw voor het bedrijf.

2. Procesinnovatie: het bedrijf heeft één of meerdere nieuwe of sterk verbeterde processen of methodes in gebruik genomen. Deze nieuwe processen of methodes kunnen betrekking hebben op:

- de productie van goederen of diensten

- de logistiek (levering of distributie) van inputs (goederen of diensten) of

- ondersteunende activiteiten voor de processen, zoals onderhoudssystemen of aankoop-, boekhoudkundige of calculatiemethodes.

De processen of methodes kunnen nieuw voor de markt zijn of alleen nieuw voor het bedrijf.

3. Lopende of afgebroken product- of procesinnovaties: het bedrijf heeft gewerkt aan product- en/of procesinnovaties zoals hierboven omschreven, maar heeft deze afgebroken en/of nog niet afgerond in de onderzochte periode.

4. Organisatorische innovaties: het bedrijf heeft één of meer van de volgende innovaties geïntroduceerd:

- nieuwe bedrijfsprocedures

- nieuwe methodes om professionele verantwoordelijkheden te organiseren en beslissingen te nemen

- nieuwe methodes om externe relaties met andere bedrijven of instellingen te organiseren

5. Marketinginnovaties: het bedrijf heeft innovaties geïntroduceerd in:

- het esthetische ontwerp of de verpakking van producten

- de wijze waarop het bedrijf nieuwe media gebruikt om producten te promoten

- de wijze waarop het bedrijf producten in de markt positioneert of nieuwe verkoopkanalen gebruikt

- de wijze waarop het bedrijf de prijs van producten bepaalt

Innovaties kunnen nieuw zijn voor een bedrijf, maar hoeven dat dan niet te zijn voor de betreffende bedrijfstak of markt. Ook kan het zijn dat een innovatie oorspronkelijk door het bedrijf zelf of door andere bedrijven is voorbereid.

\section{Research \& Development (R\&D)}

Activiteit waarbij wordt gestreefd naar oorspronkelijkheid en vernieuwing en bestaande uit het creatief, systematisch en planmatig zoeken naar oplossingen voor praktische problemen. Tot de activiteit behoort ook het strategische en het fundamentele onderzoek, waarbij het verkrijgen van achtergrondkennis en het vergroten van de (puur) wetenschappelijke kennis voorop staat en niet het streven naar direct economisch voordeel of het oplossen van problemen. Verder wordt tot de activiteit ook gerekend het (uit)ontwikkelen van ideeën of prototypes tot bruikbare processen en productierijpe producten.

\section{B3.5 Dienstenhandel door de agribusiness}

\section{Invoer van diensten}

Het verlenen van diensten door het buitenland aan ingezetenen. De invoer van diensten heeft onder meer betrekking op de uitgaven van Nederlandse bedrijven in het buitenland, zoals vervoerskosten, bankkosten en zakenreizen. Bij de overheid gaat het onder meer om uitgaven van Nederlandse ambassades en consulaten in het buitenland. De invoer door huishoudens bestaat onder meer uit ingevoerde consumptiegoederen en de directe consumptieve bestedingen van Nederlandse toeristen, grensbewoners, diplomaten en militairen in het buitenland. 


\section{Uitvoer van diensten}

Het verlenen van diensten door ingezetenen aan het buitenland. De uitvoer van diensten omvat onder meer de diensten van Nederlandse vervoerbedrijven in het buitenland, aan het buitenland bewezen havendiensten, scheepsreparatie en de uitvoering van werkzaamheden in het buitenland door Nederlandse aannemers. Onder de uitvoer vallen eveneens de bestedingen in Nederland door buitenlandse toeristen, grensbewoners en diplomaten.

\section{Ingezetene}

Een persoon of bedrijf die of dat tot de Nederlandse economie behoort. Het betreft personen die langer dan één jaar in Nederland verblijven en bedrijven die gevestigd zijn in Nederland, inclusief vestigingen van buitenlandse ondernemingen in Nederland.

\section{B3.6 Buitenlandse voedingsmiddelen- en drankenindustrie in Nederland}

\section{Buitenlandse zeggenschap}

Of een bedrijf binnenlands of buitenlands is, wordt geclassificeerd aan de hand van het land waar uiteindelijke zeggenschap plaatsvindt. Deze zeggenschap ligt bij de Ultimate Controlling Institutional Unit (UCI). De UCI is gedefinieerd als het bedrijf, hogerop in de zeggenschapsketen, waarvan het Nederlandse bedrijf deel uitmaakt, dat niet onder zeggenschap van een ander bedrijf valt. Buitenlandse zeggenschap betekent dat het land van vestiging van de UCI een ander land is dan Nederland.

\section{Outward/Inward FATS}

De statistiek Outward Fats is een indicator voor de internationalisering van het Nederlandse bedrijfsleven en wordt gemaakt op basis van waarnemingen bij de grootste niet-financiële ondernemingen. FATS staat voor 'Foreign Affiliate Trade Statistics'. 'Outward' staat voor Nederlandse dochterondernemingen in het buitenland (de 'Inward FATS' meet de buitenlandse dochterondernemingen in Nederland). De doelpopulatie van Outward Fats bestaat uit bijna alle ondernemingen die in Nederland actief zijn, waarvan de UCI in Nederland ligt en waarvoor geldt dat ze dochterondernemingen hebben buiten de EU. Niet waargenomen worden de ondernemingen met een activiteit in de landbouw en visserij, openbaar bestuur, huishoudens en extraterritoriale organisaties en lichamen.

\section{B3.7 De biologische Agro/Food-sector}

\section{Biologische landbouw}

Productiewijze in de land- en tuinbouw waarbij geen kunstmest en chemische gewasbeschermingsmiddelen worden toegepast. Biologische bedrijven maken gebruik van organische mest en biologische gewasbeschermingsmiddelen. Ook houden ze zich aan bepaalde voorschriften bij het gebruik van krachtvoer en diergeneesmiddelen.

\section{B3.8 Gebruik van duurzame agrogrondstoffen}

\section{Duurzame ontwikkeling}

Duurzame ontwikkeling is een ontwikkeling die voorziet in de behoeften van de huidige generatie, zonder de behoeften van toekomstige generaties, zowel hier als in andere delen van de wereld, in gevaar te brengen. Het gaat er hier om de vraag of wij onze kwaliteit van leven in het hier en nu op een manier vormgeven die geen al te grote druk legt op de behoeften van een voldoende kwaliteit van leven van mensen elders in de wereld of van toekomstige generaties. Zaken als consumptie, natuur, gezondheid, vertrouwen, kennis en zelf gerapporteerde tevredenheid van burgers over deze aspecten dragen bij aan hun kwaliteit van leven. 


\section{Bijlage 4 Uitgebreide tabellen handel in landbouwgoederen}

\section{B4.1 Gedetailleerd overzicht van de handel naar productgroepen en landen}

Tabel B4.1 Import van landbouw- en landbouwgerelateerde goederen.

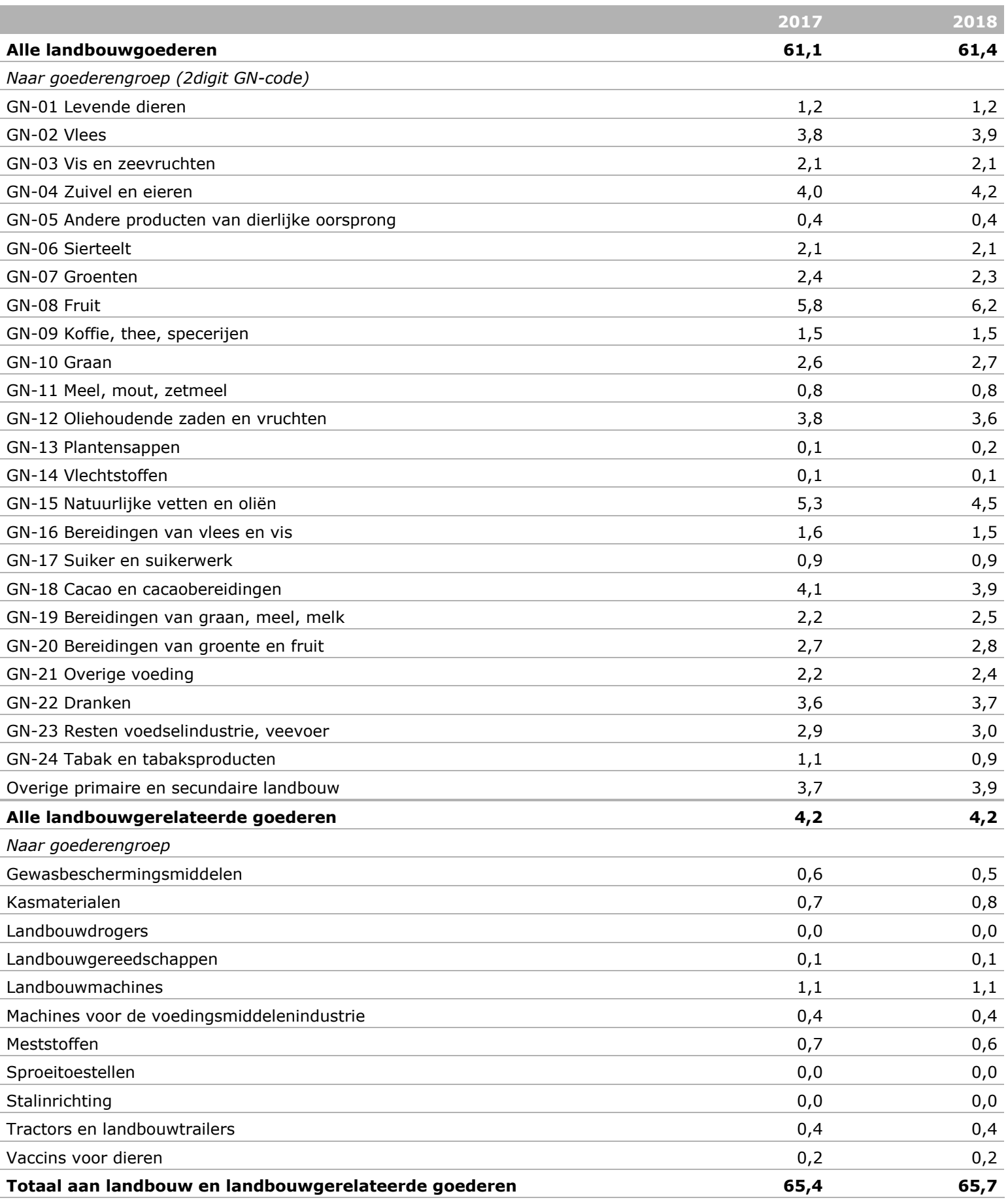

Bron: CBS tot en met oktober 2018, raming november - december 2018 door WUR en CBS. 
Tabel B4.2 Export van landbouw- en landbouwgerelateerde goederen.

\begin{tabular}{|c|c|c|c|c|c|c|}
\hline & \multicolumn{3}{|c|}{2017} & \multicolumn{3}{|c|}{2018} \\
\hline & $\begin{array}{l}\text { Nederlandse } \\
\text { makelij }\end{array}$ & $\begin{array}{l}\text { Weder- } \\
\text { uitvoer }\end{array}$ & Totaal & $\begin{array}{l}\text { Nederlandse } \\
\text { makelij }\end{array}$ & $\begin{array}{l}\text { Weder- } \\
\text { uitvoer }\end{array}$ & Totaal \\
\hline Alle landbouwgoederen & 65,3 & 24,8 & 90,1 & 65,4 & 24,9 & 90,3 \\
\hline \multicolumn{7}{|l|}{ Naar goederengroep (2digit GN-code) } \\
\hline GN-01 Levende dieren & 1,9 & 0,3 & 2,3 & 1,6 & 0,3 & 2,0 \\
\hline GN-02 Vlees & 7,1 & 1,1 & 8,2 & 7,2 & 0,9 & 8,1 \\
\hline GN-03 Vis en zeevruchten & 2,0 & 0,8 & 2,8 & 2,1 & 0,8 & 3,0 \\
\hline GN-04 Zuivel en eieren & 7,0 & 1,7 & 8,7 & 6,9 & 1,6 & 8,5 \\
\hline GN-05 Andere producten van dierlijke oorsprong & 0,2 & 0,3 & 0,5 & 0,2 & 0,4 & 0,6 \\
\hline GN-06 Sierteelt & 7,8 & 1,1 & 8,9 & 8,1 & 1,1 & 9,2 \\
\hline GN-07 Groenten & 5,6 & 1,0 & 6,6 & 5,6 & 1,0 & 6,6 \\
\hline GN-08 Fruit & 1,2 & 4,3 & 5,5 & 1,4 & 4,6 & 6,0 \\
\hline GN-09 Koffie, thee, specerijen & 0,7 & 0,3 & 1,1 & 0,6 & 0,5 & 1,1 \\
\hline GN-10 Graan & 0,2 & 0,3 & 0,5 & 0,2 & 0,3 & 0,5 \\
\hline GN-11 Meel, mout, zetmeel & 0,6 & 0,1 & 0,7 & 0,7 & 0,1 & 0,7 \\
\hline GN-12 Oliehoudende zaden en vruchten & 1,3 & 1,8 & 3,1 & 1,4 & 1,7 & 3,1 \\
\hline GN-13 Plantensappen & 0,1 & 0,0 & 0,1 & 0,1 & 0,0 & 0,1 \\
\hline GN-14 Vlechtstoffen & 0,0 & 0,0 & 0,0 & 0,0 & 0,0 & 0,0 \\
\hline GN-15 Natuurlijke vetten en oliën & 3,4 & 1,4 & 4,9 & 3,1 & 1,3 & 4,4 \\
\hline GN-16 Bereidingen van vlees en vis & 1,1 & 0,6 & 1,7 & 1,1 & 0,6 & 1,7 \\
\hline GN-17 Suiker en suikerwerk & 1,2 & 0,4 & 1,6 & 1,3 & 0,3 & 1,6 \\
\hline GN-18 Cacao en cacaobereidingen & 3,1 & 1,6 & 4,8 & 2,7 & 1,7 & 4,4 \\
\hline GN-19 Bereidingen van graan, meel, melk & 3,6 & 0,7 & 4,3 & 4,0 & 0,8 & 4,8 \\
\hline GN-20 Bereidingen van groente en fruit & 3,5 & 1,5 & 4,9 & 3,6 & 1,5 & 5,1 \\
\hline GN-21 Overige voeding & 3,1 & 1,1 & 4,2 & 3,2 & 1,2 & 4,3 \\
\hline GN-22 Dranken & 3,8 & 1,3 & 5,1 & 3,9 & 1,3 & 5,2 \\
\hline GN-23 Resten voedselindustrie, veevoer & 2,9 & 1,4 & 4,3 & 3,0 & 1,4 & 4,5 \\
\hline GN-24 Tabak en tabaksproducten & 1,0 & 0,8 & 1,7 & 0,8 & 0,4 & 1,2 \\
\hline Overige primaire en secundaire landbouw & 2,7 & 0,9 & 3,7 & 2,7 & 0,9 & 3,6 \\
\hline Alle landbouwgerelateerde goederen & 6,6 & 2,3 & 8,9 & 6,9 & 2,3 & 9,2 \\
\hline \multicolumn{7}{|l|}{ Naar goederengroep } \\
\hline Gewasbeschermingsmiddelen & 0,3 & 0,2 & 0,6 & 0,4 & 0,2 & 0,5 \\
\hline Kasmaterialen & 1,1 & 0,2 & 1,3 & 1,2 & 0,2 & 1,3 \\
\hline Landbouwdrogers & 0,0 & 0,0 & 0,0 & 0,0 & 0,0 & 0,0 \\
\hline Landbouwgereedschappen & 0,0 & 0,1 & 0,1 & 0,0 & 0,1 & 0,1 \\
\hline Landbouwmachines & 1,8 & 0,5 & 2,3 & 1,9 & 0,5 & 2,4 \\
\hline Machines voor de voedingsmiddelenindustrie & 1,5 & 0,2 & 1,7 & 1,8 & 0,2 & 2,0 \\
\hline Meststoffen & 1,4 & 0,4 & 1,8 & 1,4 & 0,3 & 1,7 \\
\hline Sproeitoestellen & 0,1 & 0,0 & 0,1 & 0,1 & 0,0 & 0,2 \\
\hline Stalinrichting & 0,0 & 0,0 & 0,0 & 0,0 & 0,0 & 0,0 \\
\hline Tractors en landbouwtrailers & 0,2 & 0,1 & 0,3 & 0,1 & 0,1 & 0,3 \\
\hline Vaccins voor dieren & 0,1 & 0,7 & 0,7 & 0,0 & 0,7 & 0,7 \\
\hline Totaal aan landbouw en -gerelateerde goederen & 71,8 & 27,1 & 99,0 & 72,3 & 27,2 & 99,5 \\
\hline
\end{tabular}

Bron: CBS tot en met oktober 2018, raming november - december 2018 door WUR en CBS. 
Tabel B4.3 Import van landbouwgoederen naar herkomstland.

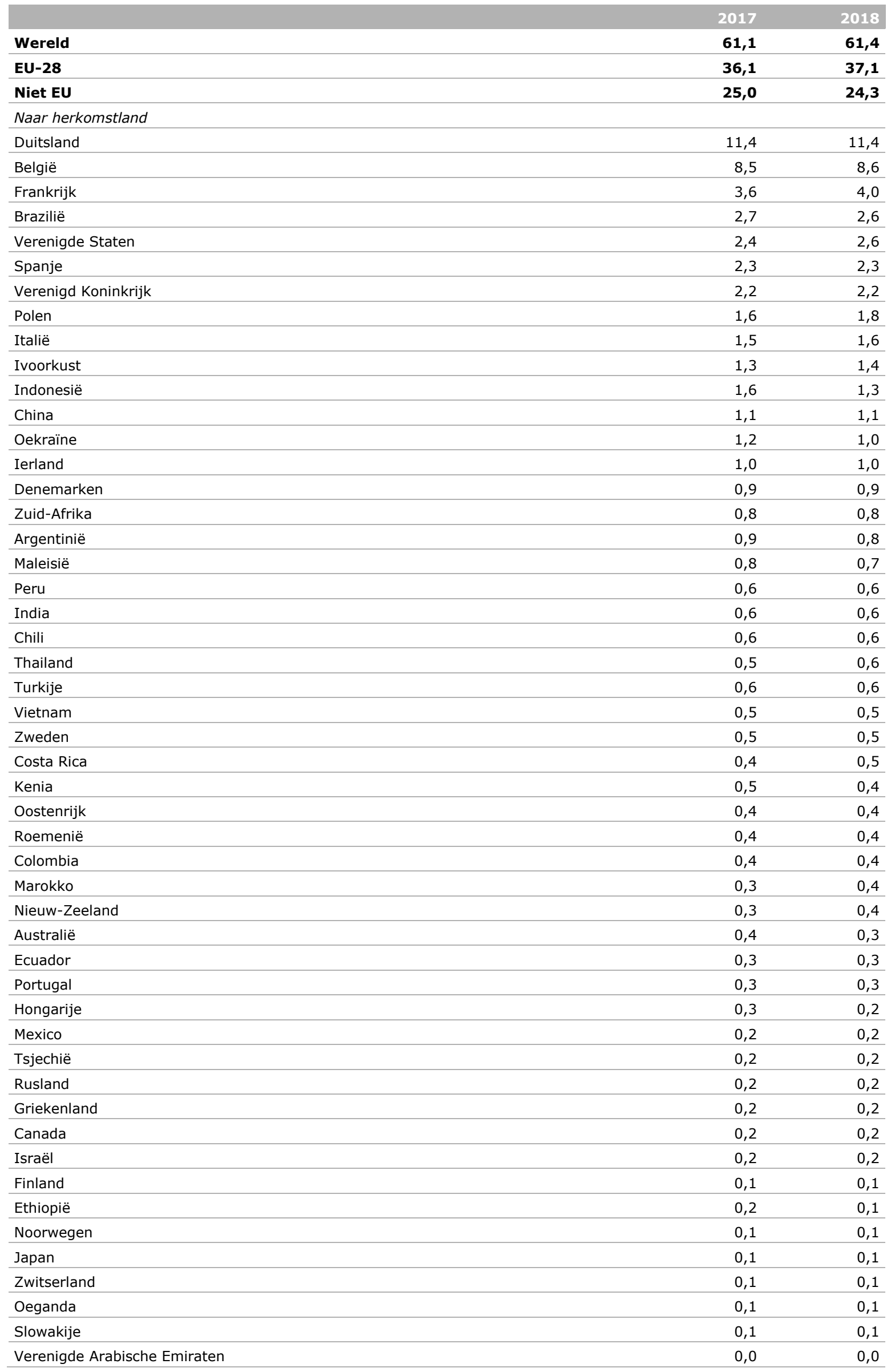

Bron: CBS tot en met oktober 2018, raming november - december 2018 door WUR en CBS. 
Tabel B4.4 Import van landbouw- en landbouwgerelateerde goederen naar herkomstland.

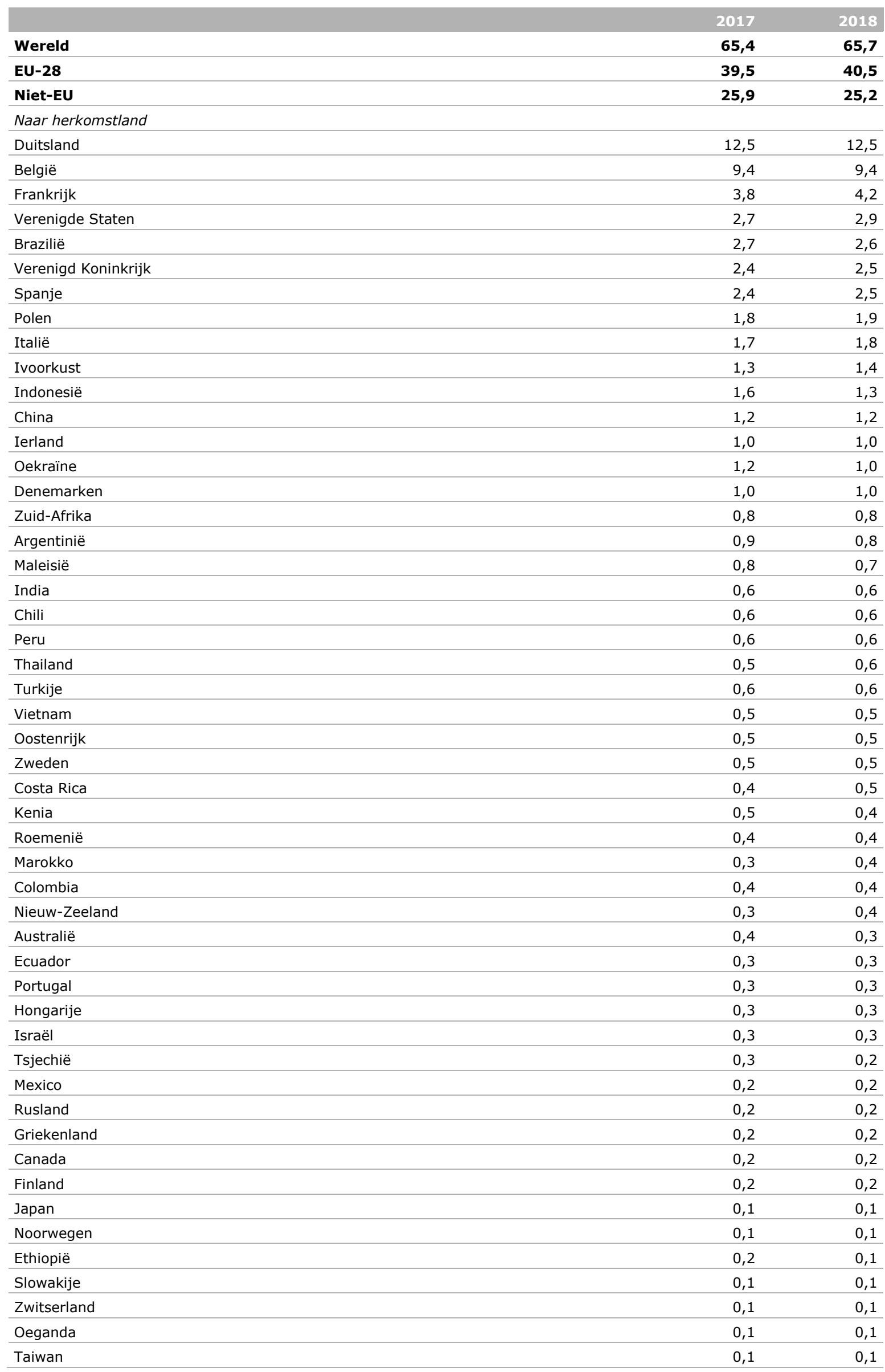

Bron: CBS tot en met oktober 2018, raming november - december 2018 door WUR en CBS. 
Tabel B4.5 Export van landbouwgoederen naar exportbestemming.

\begin{tabular}{|c|c|c|c|c|c|c|}
\hline & \multicolumn{3}{|c|}{2017} & \multicolumn{3}{|c|}{2018} \\
\hline & $\begin{array}{l}\text { Nederlandse } \\
\text { makelij }\end{array}$ & $\begin{array}{l}\text { Weder- } \\
\text { uitvoer }\end{array}$ & Totaal & $\begin{array}{l}\text { Nederlandse } \\
\text { makelij }\end{array}$ & $\begin{array}{l}\text { Weder- } \\
\text { uitvoer }\end{array}$ & Totaal \\
\hline Wereld & 65,3 & 24,8 & 90,1 & 65,4 & 24,9 & 90,3 \\
\hline EU-28 & 47,9 & 22,0 & 69,9 & 47,7 & 22,0 & 69,6 \\
\hline Niet-EU & 17,4 & 2,8 & 20,2 & 17,7 & 2,9 & 20,7 \\
\hline \multicolumn{7}{|l|}{ Naar exportbestemming } \\
\hline Duitsland & 15,1 & 7,9 & 23,1 & 15,0 & 7,8 & 22,8 \\
\hline België & 6,9 & 3,3 & 10,2 & 6,8 & 3,4 & 10,2 \\
\hline Verenigd Koninkrijk & 6,3 & 2,3 & 8,7 & 6,3 & 2,2 & 8,6 \\
\hline Frankrijk & 5,6 & 2,2 & 7,8 & 5,3 & 2,4 & 7,7 \\
\hline Italië & 2,7 & 0,7 & 3,5 & 2,7 & 0,7 & 3,4 \\
\hline Spanje & 1,8 & 0,8 & 2,6 & 1,8 & 0,8 & 2,6 \\
\hline Verenigde Staten & 2,3 & 0,2 & 2,5 & 2,2 & 0,3 & 2,5 \\
\hline China & 2,1 & 0,2 & 2,4 & 2,2 & 0,3 & 2,5 \\
\hline Polen & 1,5 & 0,8 & 2,3 & 1,6 & 0,8 & 2,4 \\
\hline Zweden & 1,4 & 0,6 & 2,0 & 1,4 & 0,6 & 2,0 \\
\hline Denemarken & 1,2 & 0,5 & 1,7 & 1,2 & 0,5 & 1,8 \\
\hline Oostenrijk & 0,7 & 0,5 & 1,1 & 0,7 & 0,5 & 1,2 \\
\hline Zwitserland & 0,9 & 0,2 & 1,1 & 0,9 & 0,2 & 1,1 \\
\hline Ierland & 0,8 & 0,4 & 1,1 & 0,8 & 0,4 & 1,1 \\
\hline Rusland & 0,7 & 0,2 & 0,9 & 0,8 & 0,2 & 1,0 \\
\hline Noorwegen & 0,6 & 0,2 & 0,9 & 0,6 & 0,3 & 0,9 \\
\hline Finland & 0,5 & 0,4 & 0,9 & 0,5 & 0,4 & 0,9 \\
\hline Tsjechië & 0,5 & 0,3 & 0,8 & 0,6 & 0,3 & 0,8 \\
\hline Griekenland & 0,7 & 0,2 & 0,9 & 0,7 & 0,1 & 0,8 \\
\hline Japan & 0,6 & 0,1 & 0,6 & 0,7 & 0,1 & 0,7 \\
\hline Turkije & 0,4 & 0,1 & 0,6 & 0,4 & 0,1 & 0,6 \\
\hline Australië & 0,4 & 0,1 & 0,5 & 0,4 & 0,1 & 0,5 \\
\hline Roemenië & 0,3 & 0,2 & 0,5 & 0,3 & 0,2 & 0,5 \\
\hline Verenigde Arabische Emiraten & 0,4 & 0,1 & 0,5 & 0,4 & 0,1 & 0,5 \\
\hline Portugal & 0,3 & 0,2 & 0,5 & 0,3 & 0,2 & 0,5 \\
\hline Hongarije & 0,4 & 0,1 & 0,5 & 0,3 & 0,1 & 0,5 \\
\hline Saoedi-Arabië & 0,4 & 0,0 & 0,4 & 0,4 & 0,1 & 0,4 \\
\hline Zuid-Korea & 0,3 & 0,0 & 0,4 & 0,3 & 0,0 & 0,4 \\
\hline Marokko & 0,2 & 0,0 & 0,3 & 0,3 & 0,0 & 0,4 \\
\hline Canada & 0,3 & 0,0 & 0,3 & 0,3 & 0,0 & 0,3 \\
\hline Mexico & 0,2 & 0,0 & 0,3 & 0,2 & 0,1 & 0,3 \\
\hline Zuid-Afrika & 0,2 & 0,1 & 0,3 & 0,2 & 0,0 & 0,3 \\
\hline Slowakije & 0,2 & 0,1 & 0,2 & 0,2 & 0,1 & 0,3 \\
\hline Vietnam & 0,2 & 0,0 & 0,3 & 0,2 & 0,0 & 0,3 \\
\hline Oekraïne & 0,2 & 0,0 & 0,2 & 0,2 & 0,1 & 0,3 \\
\hline Taiwan & 0,2 & 0,0 & 0,3 & 0,2 & 0,0 & 0,3 \\
\hline Israël & 0,2 & 0,0 & 0,2 & 0,2 & 0,0 & 0,3 \\
\hline Brazilië & 0,2 & 0,0 & 0,2 & 0,2 & 0,0 & 0,2 \\
\hline Kroatië & 0,1 & 0,1 & 0,2 & 0,1 & 0,1 & 0,2 \\
\hline Maleisië & 0,2 & 0,0 & 0,2 & 0,2 & 0,0 & 0,2 \\
\hline Indonesië & 0,1 & 0,0 & 0,1 & 0,2 & 0,0 & 0,2 \\
\hline Thailand & 0,2 & 0,1 & 0,2 & 0,1 & 0,0 & 0,2 \\
\hline Chili & 0,1 & 0,0 & 0,1 & 0,1 & 0,0 & 0,1 \\
\hline India & 0,1 & 0,0 & 0,1 & 0,1 & 0,0 & 0,1 \\
\hline Nieuw-Zeeland & 0,1 & 0,0 & 0,1 & 0,1 & 0,0 & 0,1 \\
\hline Ivoorkust & 0,1 & 0,0 & 0,1 & 0,1 & 0,0 & 0,1 \\
\hline Senegal & 0,1 & 0,0 & 0,1 & 0,1 & 0,0 & 0,1 \\
\hline Peru & 0,0 & 0,0 & 0,1 & 0,1 & 0,0 & 0,1 \\
\hline Colombia & 0,0 & 0,0 & 0,1 & 0,0 & 0,0 & 0,1 \\
\hline Angola & 0,1 & 0,0 & 0,1 & 0,1 & 0,0 & 0,1 \\
\hline
\end{tabular}

Bron: CBS tot en met oktober 2018, raming november - december 2018 door WUR en CBS. 
Tabel B4.6 Export van landbouw- en landbouwgerelateerde goederen naar exportbestemming.

\begin{tabular}{|c|c|c|c|c|c|c|}
\hline & \multicolumn{3}{|c|}{2017} & \multicolumn{3}{|c|}{2018} \\
\hline & $\begin{array}{l}\text { Nederlandse } \\
\text { makelij }\end{array}$ & $\begin{array}{l}\text { Weder- } \\
\text { uitvoer }\end{array}$ & Totaal & $\begin{array}{l}\text { Nederlandse } \\
\text { makelij }\end{array}$ & $\begin{array}{l}\text { Weder- } \\
\text { uitvoer }\end{array}$ & Totaal \\
\hline Wereld & 71,8 & 27,1 & 99,0 & 72,3 & 27,2 & 99,5 \\
\hline EU-28 & 51,7 & 23,6 & 75,3 & 51,5 & 23,6 & 75,1 \\
\hline Niet-EU & 20,1 & 3,5 & 23,7 & 20,8 & 3,6 & 24,4 \\
\hline \multicolumn{7}{|l|}{ Naar exportbestemming } \\
\hline Duitsland & 16,1 & 8,4 & 24,5 & 16,0 & 8,2 & 24,2 \\
\hline België & 7,5 & 3,5 & 11,1 & 7,5 & 3,7 & 11,2 \\
\hline Verenigd Koninkrijk & 6,8 & 2,5 & 9,3 & 6,8 & 2,4 & 9,2 \\
\hline Frankrijk & 6,2 & 2,4 & 8,6 & 5,9 & 2,6 & 8,4 \\
\hline Italië & 2,9 & 0,8 & 3,7 & 2,9 & 0,8 & 3,7 \\
\hline Verenigde Staten & 2,8 & 0,3 & 3,0 & 2,8 & 0,3 & 3,1 \\
\hline Spanje & 2,0 & 0,9 & 2,9 & 2,0 & 0,9 & 2,9 \\
\hline China & 2,3 & 0,3 & 2,6 & 2,4 & 0,3 & 2,7 \\
\hline Polen & 1,7 & 0,9 & 2,6 & 1,8 & 0,9 & 2,7 \\
\hline Zweden & 1,5 & 0,6 & 2,1 & 1,5 & 0,6 & 2,1 \\
\hline Denemarken & 1,3 & 0,6 & 1,9 & 1,4 & 0,6 & 1,9 \\
\hline Oostenrijk & 0,7 & 0,5 & 1,2 & 0,8 & 0,5 & 1,3 \\
\hline Zwitserland & 1,0 & 0,3 & 1,2 & 1,0 & 0,3 & 1,2 \\
\hline Rusland & 1,0 & 0,2 & 1,3 & 1,0 & 0,2 & 1,2 \\
\hline Ierland & 0,8 & 0,4 & 1,2 & 0,8 & 0,4 & 1,2 \\
\hline Noorwegen & 0,8 & 0,3 & 1,1 & 0,7 & 0,3 & 1,0 \\
\hline Finland & 0,6 & 0,4 & 1,0 & 0,5 & 0,4 & 0,9 \\
\hline Tsjechië & 0,6 & 0,3 & 0,9 & 0,6 & 0,3 & 0,9 \\
\hline Griekenland & 0,7 & 0,2 & 0,9 & 0,7 & 0,2 & 0,9 \\
\hline Japan & 0,7 & 0,1 & 0,7 & 0,8 & 0,1 & 0,9 \\
\hline Australië & 0,5 & 0,1 & 0,6 & 0,5 & 0,1 & 0,6 \\
\hline Turkije & 0,5 & 0,1 & 0,6 & 0,5 & 0,1 & 0,6 \\
\hline Roemenië & 0,4 & 0,2 & 0,6 & 0,4 & 0,2 & 0,6 \\
\hline Verenigde Arabische Emiraten & 0,5 & 0,1 & 0,6 & 0,4 & 0,1 & 0,5 \\
\hline Portugal & 0,3 & 0,2 & 0,5 & 0,4 & 0,2 & 0,5 \\
\hline Hongarije & 0,4 & 0,2 & 0,6 & 0,4 & 0,2 & 0,5 \\
\hline Canada & 0,4 & 0,0 & 0,4 & 0,5 & 0,0 & 0,5 \\
\hline Saoedi-Arabië & 0,4 & 0,1 & 0,5 & 0,4 & 0,1 & 0,5 \\
\hline Brazilië & 0,3 & 0,1 & 0,4 & 0,4 & 0,1 & 0,4 \\
\hline Zuid-Korea & 0,4 & 0,1 & 0,4 & 0,4 & 0,1 & 0,4 \\
\hline Mexico & 0,3 & 0,0 & 0,4 & 0,3 & 0,1 & 0,4 \\
\hline Marokko & 0,3 & 0,0 & 0,3 & 0,3 & 0,0 & 0,4 \\
\hline Zuid-Afrika & 0,2 & 0,1 & 0,3 & 0,3 & 0,1 & 0,4 \\
\hline Oekraïne & 0,2 & 0,1 & 0,3 & 0,2 & 0,1 & 0,3 \\
\hline Vietnam & 0,3 & 0,1 & 0,3 & 0,3 & 0,0 & 0,3 \\
\hline Slowakije & 0,2 & 0,1 & 0,3 & 0,2 & 0,1 & 0,3 \\
\hline Israël & 0,2 & 0,0 & 0,3 & 0,2 & 0,0 & 0,3 \\
\hline Taiwan & 0,2 & 0,1 & 0,3 & 0,2 & 0,1 & 0,3 \\
\hline Thailand & 0,2 & 0,1 & 0,3 & 0,2 & 0,1 & 0,3 \\
\hline Maleisië & 0,2 & 0,0 & 0,2 & 0,2 & 0,0 & 0,3 \\
\hline Kroatië & 0,2 & 0,1 & 0,2 & 0,2 & 0,1 & 0,2 \\
\hline Indonesië & 0,2 & 0,0 & 0,2 & 0,2 & 0,0 & 0,2 \\
\hline Chili & 0,1 & 0,0 & 0,2 & 0,1 & 0,0 & 0,2 \\
\hline Nieuw-Zeeland & 0,1 & 0,0 & 0,1 & 0,1 & 0,0 & 0,2 \\
\hline India & 0,1 & 0,0 & 0,1 & 0,1 & 0,0 & 0,1 \\
\hline Argentinië & 0,1 & 0,0 & 0,1 & 0,1 & 0,0 & 0,1 \\
\hline Ivoorkust & 0,1 & 0,0 & 0,1 & 0,1 & 0,0 & 0,1 \\
\hline Colombia & 0,1 & 0,0 & 0,1 & 0,1 & 0,0 & 0,1 \\
\hline Peru & 0,1 & 0,0 & 0,1 & 0,1 & 0,0 & 0,1 \\
\hline Senegal & 0,1 & 0,0 & 0,1 & 0,1 & 0,0 & 0,1 \\
\hline
\end{tabular}

Bron: CBS tot en met oktober 2018, raming november - december 2018 door WUR en CBS. 
Wageningen Economic Research Postbus 29703

2502 LS Den Haag

T 0703358330

Ecommunications.ssg@wur.nl

www.wur.nl/economic-research

Wageningen Economic Research RAPPORT

2019-001
De missie van Wageningen University \& Research is 'To explore the potential of nature to improve the quality of life'. Binnen Wageningen University \& Research bundelen Wageningen University en gespecialiseerde onderzoeksinstituten van Stichting Wageningen Research hun krachten om bij te dragen aan de oplossing van belangrijke vragen in het domein van gezonde voeding en leefomgeving. Met ongeveer 30 vestigingen, 5.000 medewerkers en 10.000 studenten behoort Wageningen University \& Research wereldwijd tot de aansprekende kennisinstellingen binnen haar domein. De integrale benadering van de vraagstukken en de samenwerking tussen verschillende disciplines vormen het hart van de unieke Wageningen aanpak. 



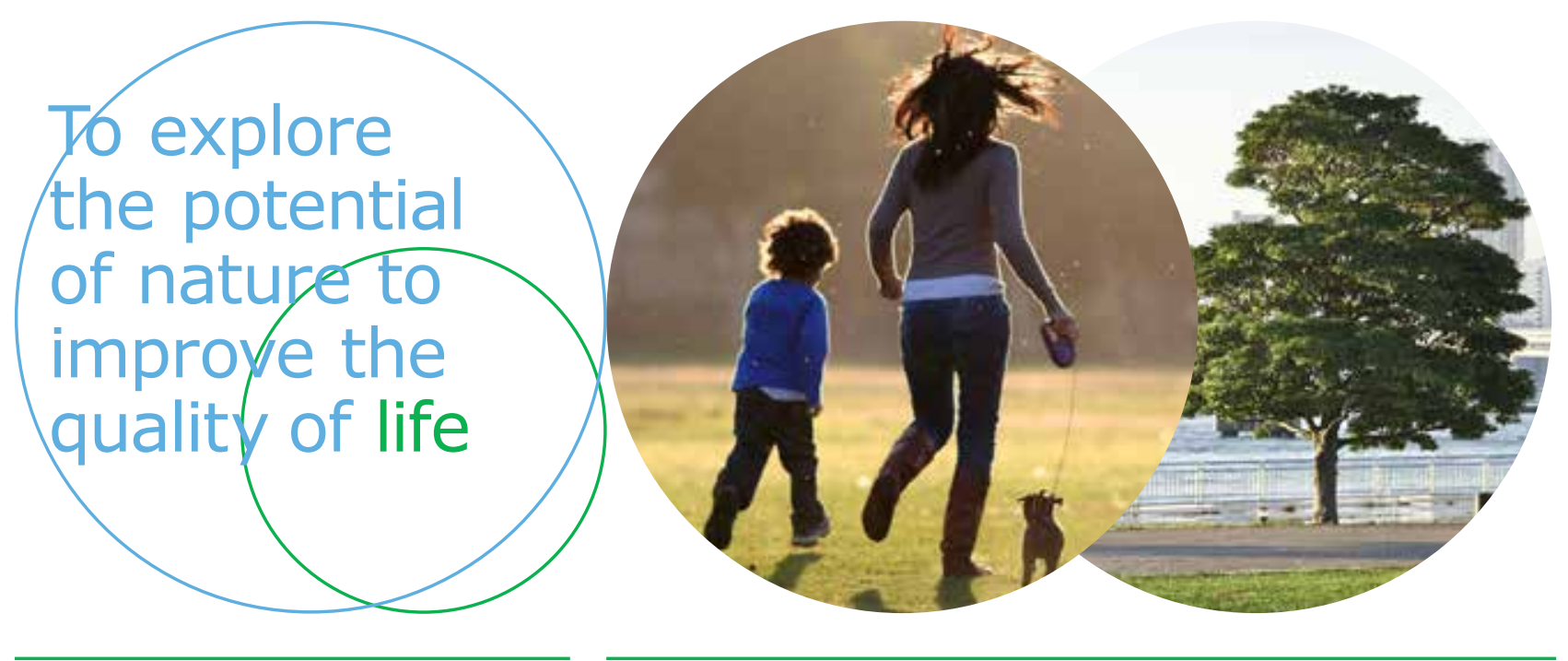

Wageningen Economic Research Postbus 29703

2502 LS Den Haag

E communications.ssg@wur.nl

T+31(0)7033583 30

www.wur.nl/economic-research

Rapport 2019-001

ISBN 978-94-6343-405-8
De missie van Wageningen University \& Research is 'To explore the potential of nature to improve the quality of life'. Binnen Wageningen University \& Research bundelen Wageningen University en gespecialiseerde onderzoeksinstituten van Stichting Wageningen Research hun krachten om bij te dragen aan de oplossing van belangrijke vragen in het domein van gezonde voeding en leefomgeving. Met ongeveer 30 vestigingen, 5.000 medewerkers en 10.000 studenten behoort Wageningen University \& Research wereldwijd tot de aansprekende kennisinstellingen binnen haar domein. De integrale benadering van de vraagstukken en de samenwerking tussen verschillende disciplines vormen het hart van de unieke Wageningen aanpak. 